\title{
Comparison of Selected DOE and Non-DOE Requirements, Standards, and Practices for Low-Level Radioactive Waste Disposal
}

\section{Radioactive Waste Technical Support} Program

December 1995 

DOE/LLW-225

Revision 0

\title{
Comparison of Selected DOE and Non-DOE Requirements, Standards, and Practices for Low-Level Radioactive Waste Disposal
}

\author{
Lance Cole \\ Cole and Associates \\ Don Kudera \\ William Newberry \\ Lockheed Idaho Technologies Company
}

December 1995

Idaho National Engineering Laboratory

Lockheed Idaho Technologies Company

Idaho Falls, Idaho 83415

Prepared for the

U.S. Department of Energy

Assistant Secretary for Environmental Management

Under DOE Idaho Operations Office

Contract DE-AC07-94ID13223 
and 


\begin{abstract}
This document results from the Secretary of Energy's response to Defense Nuclear Facilities Safety Board Recommendation 94-2. The Secretary stated that the U.S. Department of Energy (DOE) would "address such issues as...the need for additional requirements, standards, and guidance on low-level radioactive waste management." The authors gathered information and compared DOE requirements and standards for the safety aspects of low-level radioactive waste disposal with similar requirements and standards of non-DOE entities.
\end{abstract}

\title{
DISCLAIMER
}

This report was prepared as an account of work sponsored by an agency of the United States Government. Neither the United States Government nor any agency thereof, nor any of their employees, makes any warranty, express or implied, or assumes any legal liability or responsibility for the accuracy, completeness, or usefulness of any information, apparatus, product, or process disclosed, or represents that its use would not infringe privately owned rights. Reference herein to any specific commercial product, process, or service by trade name, trademark, manufacturer, or otherwise does not necessarily constitute or imply its endorsement, recommendation, or favoring by the United States Government or any agency thereof. The views and opinions of authors expressed herein do not necessarily state or reflect those of the United States Government or any agency thereof. 


\section{CONTENTS}

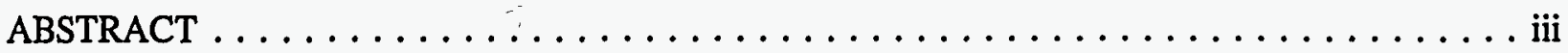

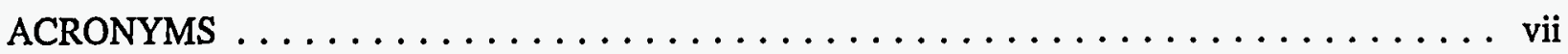

1. INTRODUCTION $\ldots \ldots \ldots \ldots \ldots \ldots \ldots \ldots \ldots \ldots \ldots \ldots \ldots \ldots \ldots \ldots \ldots$

2. HISTORY OF U.S. GOVERNMENT REGULATION

OF RADIOACTIVE MATERIALS $\ldots \ldots \ldots \ldots \ldots \ldots \ldots \ldots \ldots \ldots \ldots \ldots \ldots \ldots$

2.1 NRC Approach to Regulating LLW Disposal $\ldots \ldots \ldots \ldots \ldots \ldots \ldots \ldots$

2.2 DOE Approach to Regulating LLW Disposal $\ldots \ldots \ldots \ldots \ldots \ldots \ldots$

3. METHODOLOGY FOR COMPARISONS $\ldots \ldots \ldots \ldots \ldots \ldots \ldots \ldots \ldots \ldots \ldots$

4. DIFFERENCES IN REQUIREMENTS,

GUIDANCE, AND PRACTICES BASED ON COMPARISONS $\ldots \ldots \ldots \ldots \ldots \ldots 12$

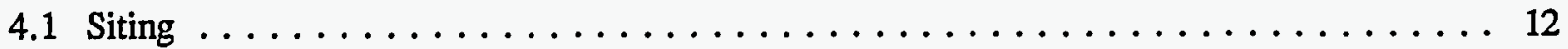

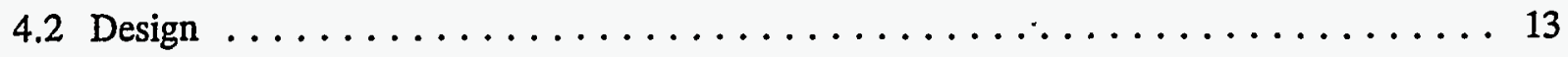

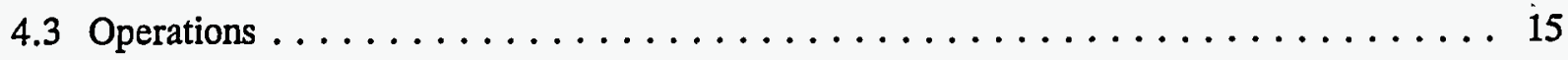

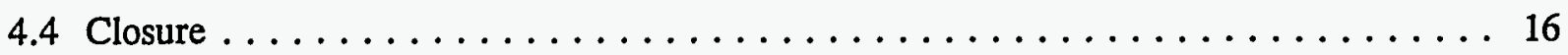

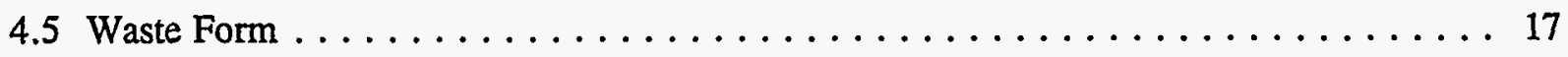

4.5.1 Waste Stabilization $\ldots \ldots \ldots \ldots \ldots \ldots \ldots \ldots \ldots \ldots \ldots \ldots \ldots \ldots \ldots$

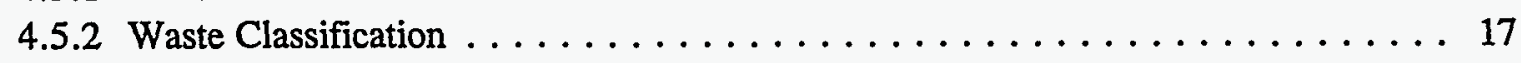

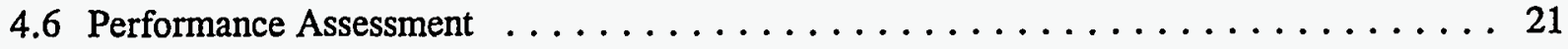

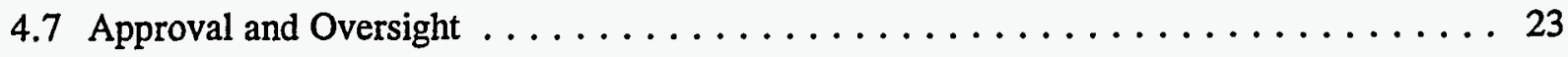

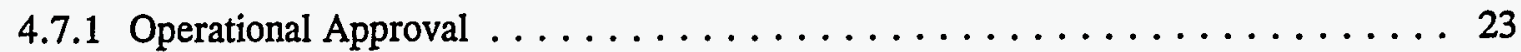

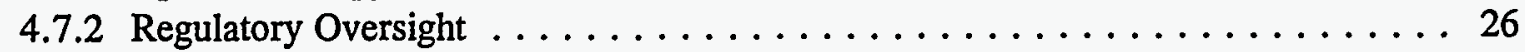

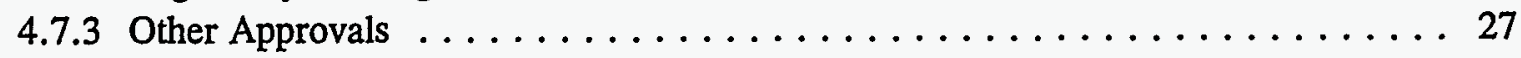

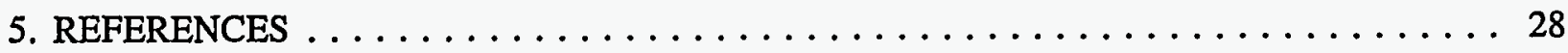

Appendix A-Safety Related Topics for Comparison $\ldots \ldots \ldots \ldots \ldots \ldots \ldots \ldots \ldots \ldots$ A-1

Appendix B-Comparison of NRC and DOE Disposal Requirements $\ldots \ldots \ldots \ldots \ldots$ B-1 
Appendix C-Comparison of Non-DOE and DOE Waste Acceptance Criteria $\ldots \ldots \ldots \ldots$. . . C-1

Appendix D-Comparison of DOE and Non-DOE Performance Assessment Requirements,

Guidance, and Practices

D-1

\section{TABLES}

1. DOE low-level waste disposal facility description $\ldots \ldots \ldots \ldots \ldots \ldots \ldots$

2. Non-DOE current and planned low-level waste disposal facility descriptions . . . . . . . . . 14

3. Comparison of DOE, NRC, and IAEA waste classification systems $\ldots \ldots \ldots \ldots$

4. Categories of documentation for $\mathrm{LLW}$ disposal facilities $\ldots \ldots \ldots \ldots \ldots \ldots$ 


\section{ACRONYMS}

AEC

ALARA

CFR

CH-TRU

DAS

DNFSB

DOE

DOE-HQ

EIS

ERDA

FR

GTCC

HLW

IAEA

ICRP

INEL

LLW

NEPA

NRC

ORNL

ORR

PA
Atomic Energy Commission

as low as reasonably achievable

Code of Federal Regulations

contact-handled TRU

Deputy Assistant Secretary

Defense Nuclear Facilities Safety Board

U.S. Department of Energy

U.S. Department of Energy-Headquarters

Environmental Impact Statement

Energy Research and Development Administration

Federal Register

greater-than-Class C

high-level waste

International Atomic Energy Agency

International Commission on Radiological Protection

Idaho National Engineering Laboratory

low-level radioactive waste

National Environmental Policy Act

U.S. Nuclear Regulatory Commission

Oak Ridge National Laboratory

Operational Readiness Review

-performance assessment 
PRP

PSO

RADWASS Radioactive Waste Safety Standards

RH-TRU

RWMC

SLLW

TRU

WIPP peer review panel

Program Secretarial Officer

remote-handled TRU

Radioactive Waste Management Complex

solid low-level waste

transuranic

Waste Isolation Pilot Plant 


\section{Comparison of Selected DOE and Non-DOE Requirements, Standards, and Practices for . Low-Level Radioactive Waste Disposal}

\section{INTRODUCTION}

In 1988, the U.S. Congress established the Defense Nuclear Facilities Safety Board (DNFSB) to provide independent oversight relative to the design, construction, operation, and decommissioning of certain defense nuclear facilities of the U.S. Department of Energy (DOE). On September 8, 1994, the DNFSB issued Recommendation 94-2, "Conformance with Safety Standards at DOE Low-Level Nuclear Waste and Disposal Sites." In response, by letter dated October 28, 1994, the Secretary of Energy accepted Recommendation 94-2 and stated that the DOE would "address such issues as ... the need for additional requirements, standards and guidance on low-level radioactive waste management."

On March 31, 1995, the Secretary of Energy issued the DNFSB Recommendation 94-2 Implementation Plan, which outlines the actions DOE will take to respond to the recommendations. Section VI of the Implementation Plan commits DOE to perform several tasks, one of which is Task B.6, "Review Commercial and International Standards and Requirements and Compare to DOE Standards and Requirements."

This report was prepared to fulfill task VI.B.6. To accomplish this, contributors gathered information and compared DOE requirements and standards for the safety aspects of the disposal of low-level radioactive waste (LLW) with similar non-DOE requirements and standards, and highlighted the differences. The non-DOE requirements are those applicable to licensees of the Nuclear Regulatory Commission (NRC) or Agreement States. These facilities are generally located on government-owned land and operated by commercial entities. This report is not intended to offer a judgment about whether one method is better than another.

In comparing regulatory systems the term "standards" cannot easily be distinguished from the term "requirements." Therefore, to avoid confusion, the term "standards" is not normally used in this document. For purposes of this document, "requirements" include both mandated actions and standards imposed by DOE-Headquarters (DOE-HQ), the NRC, or Agreement States. The term "practices" refers to the approaches taken by individual DOE field offices or by state licensees to meet technical requirements. An example of a practice is the use of a specific computer code (in lieu of others that are available) for performance assessment work to calculate dose to the most exposed individual.

The scope of the review includes the comparison of safety-related topics found in the following types of documents:

- $\quad$ NRC regulations and guidance

- Agreement State requirements 
- DOE orders and guidance

- Non-DOE license conditions and requirements

- Disposal facility waste acceptance criteria

- International programs such as the International Atomic Energy Agency (IAEA) Radioactive Waste Safety Standards (RADWASS)

- $\quad$ Site-specific performance assessment (PA) documents.

Section 2 of this report provides background information and a brief history of NRC and DOE LLW disposal activities. Section 3 describes the method used for selecting the topics for comparison and the criteria for identifying differences. Section 4 summarizes the differences that were found by comparing the requirements, guidance, or practices for the different topics. The appendices contain more detailed comparisons from which many of the differences were derived. Some of the differences were observed while reviewing documents such as disposal facility licenses and publications discussing disposal practices at facilities outside the United States.

Information on IAEA requirements, guidance, and practices was obtained by review of a list of IAEA documents from an IAEA Order Form for Radioactive Waste Management Publications, dated January 1995. Twelve older IAEA documents (dated 1965 to 1989) were obtained locally and reviewed. These consisted of eight Safety Series, two Technical Report Series, and proceedings from two symposia. The authors decided that appropriate documents for use in this report would come from the RADWASS series of international consensus documents, which are designed to make more evident the agreements by member countries regarding approaches to establishing safety. Of 24 planned RADWASS documents that might have been appropriate for this comparison, only two were available, Classification of Radioactive Waste, A Safety Guide, Safety Series No. 111-G-1.1, dated 1994,' and Siting of Near Surface Disposal Facilities, Safety Series No. 111-G-3.1, dated 1994. ${ }^{2}$ Some information from these two documents was used in this report. Other RADWASS documents are currently pending approval or scheduled for later publication. 


\section{HISTORY OF U.S. GOVERNMENT REGULATION OF RADIOACTIVE MATERIALS}

The first major use of radioactive material was by the Manhattan Engineering District whose single purpose was to develop and produce a useable nuclear weapon. Waste management activities were driven by the existing knowledge of radiological health and safety hazards, with consideration for the urgency of the national defense project. Sites and contractors developed waste management programs largely in isolation both from each other and from headquarters control.

The Atomic Energy Act of 1946 transferred Manhattan Engineering District facilities and responsibilities to the civilian-controlled Atomic Energy Commission (AEC). The Act stressed that the Commission's paramount objective remained "assuring the common defense and security." In the early days, the AEC allowed contractors to establish waste management standards, usually following consultation with AEC staff. The AEC guidelines limited exposure of employees to the maximum permissible levels recommended by the National Committee on Radiation Protection. Offsite exposures were to be held to one tenth to one hundredth of the maximum permissible limits. Low-level wastes were often diluted and dispersed to the environment because it was assumed that they presented no serious hazard. High-level waste (HLW) was considered the major waste problem and these wastes were concentrated and contained.

AEC licensing and regulatory oversight of organizations outside the agency that possessed nuclear materials began with the growth in civilian uses of nuclear materials. Regulation was necessary to control the distribution of nuclear materials and to ensure that organizations outside the AEC that managed these materials adhered to the safeguards observed within the agency.

In response to increased commercial use of nuclear materials, the AEC announced in 1960 that regional land disposal sites for commercially generated LLW should be established by the private sector. The disposal sites would be located on government-owned land (Federal or state) and would be licensed and regulated by the AEC. The announcement roughly coincided with the establishment of the Agreement State program, under a 1959 amendment to the Atomic Energy Act of 1954. Under the program, states with regulatory programs substantially equivalent to those of the AEC could assume licensing and regulatory authority over most categories of radioactive materials owners, other than nuclear power reactors and the AEC itself.

The AEC required Agreement States to adopt waste disposal regulations which were compatible with those of the AEC. Beyond this, the states were given authority to develop supplementary requirements and guidance consistent with the framework of the disposal regulations. While states were empowered to develop their own guidance, for practical reasons most have chosen to adopt, formally or informally, the technical guidance developed by the staff and contractors of the AEC and its successor agencies.

The Energy Reorganization Act of 1974 split the AEC into two organizations, the Energy Research and Development Administration (ERDA) and the NRC. The ERDA was directed to continue the Federal government's programs for management of nuclear-related programs for research and development and national defense. ERDA was later eliminated and its functions were absorbed by the Department of Energy, which was created by the Department of Energy Organization Act of 1977. 
The Reorganization Act assigned to the NRC responsibility for regulating organizations outside ERDA that possess nuclear materials. The Reorganization Act limited NRC's licensing authority to only selected ERDA facilities. Congress intended that defense-related ERDA activities be selfregulated by ERDA because national defense is the responsibility of the federal government, not the states. NRC/state licensing activities were primarily intended to impose a regulation system for independent private contractors of nondefense-related nuclear activities. At that time, because of the common origin, the standards that were to be enforced by the NRC against licensees were essentially those that had been developed by the old AEC.

Although the NRC and DOE were no longer under the same managerial umbrella, cooperation and technical consultation continued. The NRC has called upon the system of national laboratories, mostly under DOE management, to conduct many of the technical studies related to pathway analysis, computer code development, engineered barriers analysis, and other technical issues that have provided the knowledge base for the development of the NRC's regulations for LLW disposal. Thus, both agencies essentially draw from the same pool of technical data in the development of requirements and standards. Because of the different circumstances and needs of commercial and defense facilities, the regulatory approach taken by the NRC and DOE has diverged over the years. These approaches are discussed in the sections that follow.

\subsection{NRC Approach to Regulating LLW Disposal}

Largely due to problems encountered at some of the early commercially-operated disposal facilities (Maxey Flats, West Valley, and Sheffield), the NRC in the late 1970s and early 1980s established a comprehensive regulatory framework for LLW disposal, codified as Title 10 of the Code of Federal Regulations (CFR), Part 61. The Environmental Impact Statement (EIS) for the regulations ${ }^{3}$ provides the rationale for their development: ${ }^{\mathrm{a}}$

Current NRC regulations for licensing radioactive materials do not contain sufficient technical standards or criteria for the disposal of licensed materials as waste.

Comprehensive standards, technical criteria, and licensing procedures are needed to ensure the public health and safety and long-term environmental protection in the licensing of new disposal sites. They are also needed with respect to operation of the existing sites and with respect to final closure and stabilization of all sites. The development of these regulations has been in response to needs and requests expressed by the public, Congress, industry, the states, the commission and other federal agencies for codification of regulations for the disposal of LLW.

In developing the rule, the NRC considered several alternative approaches and decided upon one that included both performance objectives and prescriptive technical requirements. A system limited to detailed technical requirements was rejected because it might "discourage use of new or creative solutions to waste disposal problems. "4 The NRC also believed that such requirements might need to be revised frequently in response to improvements in waste form and disposal technologies. For this

a. Reference 3 is the NRC's final EIS. Reference 4 is the draft EIS. The NRC chose not to revise large sections of the draft for inclusion in the final revision; therefore, both the draft and the final EIS were issued. This report quotes material from both revisions. 
reason, the technical requirements included in the regulation, except those addressing waste classification, were worded in a general, qualitative manner. The NRC also rejected the option of limiting regulatory requirements to performance objectives. As stated in the Draft EIS for Part 61:

Development of purely performance objective requirements, while workable, would not allow for establishment of more detailed prescriptive requirements in those areas where specific guidance is known to be needed. In this rulemaking effort, NRC thus plans to establish overall performance objectives or standards of performance that should be achieved in the disposal of LLW, minimum technical performance requirements that should be considered in all cases in the disposal of LLW and where possible, detailed prescriptive requirements. Subsequent to this rulemaking, NRC plans to publish regulatory guides in the areas of waste form, site suitability and design and operations which will provide detailed prescriptive guidance. ${ }^{4}$

Primary among the NRC performance objectives is a requirement that the site not release radioactive material into the environment in concentrations that would result in an annual dose equivalent $t^{b}$ to any member of the general population exceeding 25 mrem to the whole body, 75 mrem to the thyroid, or 25 mrem to any other organ (10 CFR 61.41). To demonstrate that the site meets the performance objective, NRC expects that computer models will be used that make use of specific assumptions about the disposed waste, the location of the most exposed individual with respect to the disposal site, and the pathways that migrating radionuclides might take to reach this individual.

While the NRC's technical requirements are generally qualitative, the regulations establish specific and quantitative requirements with regard to the concentration limits allowed in waste disposed of in near-surface facilities (10 CFR 61.55). The rationale for uniform waste classification tables applicable to all NRC near-surface disposal facilities is based on exposure to a hypothetical future "inadvertent intruder" who excavates directly into the waste disposal units. Under the scenario, the dose equivalent to the intruder depends primarily on the concentration of radionuclides, the waste form itself, and the depth of burial.

The intruder dose equivalent is relatively independent of site-specific factors, including the size of the site, total site radiological inventory, environmental conditions, and physical site characteristics. For this reason, the NRC elected not to include specific performance objectives addressing radiation exposures to a hypothetical inadvertent intruder. In place of that performance objective, technical requirements were imposed in Subpart D of 10 CFR 61 requiring use of the NRC waste classification system and stabilization requirements. Requirements for either a minimum disposal depth (five meters for Class $C$ waste) or an engineered intruder barrier are prescribed by 10 CFR 61.52.

The NRC used $500 \mathrm{mrem} / \mathrm{yr}$ as the dose equivalent limit for scenarios involving a hypothetical inadvertent intruder. The concentration limits for class $A$ waste were set so that the intruder would not exceed the dose equivalent limit under a number of scenarios involving direct excavation into the waste. The NRC increased this concentration limit by a factor of 10 for Class $C$ waste because of the lower probability of the intruder coming into contact with the waste, primarily because of its burial at additional depth or engineered intrusion barriers.

b. See discussion and definition of the term "dose equivalent" in Section 4.6. 
Although inadvertent intrusion was the de facto basis for the classification system, it was not the driving force behind the regulation. The highest priorities were to minimize radioactive releases to the environment and to minimize the need for active disposal facility maintenance following closure. To accomplish these goals, the NRC imposed generic structural stability requirements on higher activity wastes (classes B and C) realizing that these waste classes contain approximately 95 percent of the radioactivity in commercial LLW. The regulation left room for disposal facilities to impose additional stabilization requirements as needed for site-specific considerations.

The approach of using both technical requirements and performance objectives is intended to promote the safety of the operating disposal facility and, in some cases, to prescribe defense-in-depth design requirements for the facility. Defense-in-depth design requirements include waste form stabilization requirements that provide radionuclide migration barriers independent of the site geological characteristics. Technical requirements beyond those prescribed in $10 \mathrm{CFR} 61$, such as inventory limits, are sometimes imposed as administrative license conditions to ensure that the facility performs in accordance with the Part 61 performance objectives. The technical requirements outlined in 10 CFR 61, Subpart D include:

- Disposal site suitability requirements

- Site design requirements

- Operational requirements

- Closure requirements

- Requirements for waste classification

- Prohibitions and limits related to the form of the waste

- Environmental monitoring

- Institutional requirements.

\subsection{DOE Approach to Regulating LLW Disposal}

The DOE's policies and guidelines for managing the Department's LLW were formally established in February 1984 with the publication of DOE Order 5820.2, Radioactive Waste Management. This order replaced the policies of the AEC that had evolved over the years. In 1986 DOE initiated a revision of DOE Order 5820.2, Chapter III, Management of Low-Level Waste. DOE established a working group to draft a prescriptive or performance objective-oriented revision of the LLW chapter of the order. DOE-HQ expanded this initiative and issued formal direction to rewrite the entire order. The revision was intended to address the requests of disposal site operators that DOE Order 5820.2 should establish more definitive requirements, such as generation, characterization, acceptance criteria, treatment, shipment, storage, and disposal of waste, and disposal site closure, environmental monitoring, quality assurance, and records and reports. 
In early 1987 , as part of the order revision process, DOE considered establishing a LLW classification system for inclusion in the revised order. Consideration was given to establishing Class I, II, and III limits based primarily on hypothetical inadvertent intruder exposures. A waste classification table was developed and later revised by DOE-HQ to address NRC concerns that the draft DOE dose limits were different from those of the NRC, thereby putting two agencies in differing public positions. The revised table did not cover all radionuclides reported as significant by the major DOE waste disposal sites, particularly uranium, thorium, and radium. This created problems for DOE sites because the radionuclides listed in the table more closely represented waste streams from commercial reactors than those in DOE waste streams.

Although there was much support for establishing a DOE waste classification system, the system was not adopted. (Reference 5 gives more details of the 1987 effort to establish a waste classification system and more fully explains the reasons why a DOE-specific waste classification system was not used.) A reference to the greater-than-Class C (GTCC) waste classification found in the NRC regulations is included in DOE Order 5820.2A, which requires that the DOE equivalent of that waste be handled as special case wastes. Disposal of these wastes in near-surface facilities must be justified by a waste-specific PA through the National Environmental Policy Act (NEPA) process with concurrence from designated DOE-HQ officials.

The revised DOE Order (5820.2A) was approved on September 26,1988 , and is currently in use. The DOE elected to establish a functional performance objective to limit the effective dose equivalent ${ }^{\circ}$ to a hypothetical inadvertent intruder. Engineered modifications (stabilization, packaging, burial depth, and barriers) for specific waste types and for specific waste compositions (fission products, induced radioactivity, uranium, thorium, and radium) are developed through the performance assessment model. In the course of this process, site-specific waste classification limits are developed, if they are found to be operationally useful in determining how specific wastes should be stabilized. Thus, any waste acceptance criteria and associated waste form requirements found necessary to limit individual or hypothetical inadvertent intruder exposure are established on a site-specific basis, and are based on calculations of dose under a credible, worst-case, site-specific scenario.

DOE established functional criteria (performance objectives) in DOE Order 5820.2A for each site to use as the basis for design and operation of LLW disposal sites. The performance objectives include public exposure and environmental release limits and allowable effective dose equivalent limits for a hypothetical inadvertent intruder. Primary among the DOE performance objectives is a requirement that the site not release radioactive material into the environment in concentrations that would result in an annual effective dose equivalent exceeding $25 \mathrm{mrem}$ to any member of the general population. Releases to the atmosphere must meet the requirements of 40 CFR 61 . The order also includes the following performance objective for the inadvertent intruder: "Assure that the committed effective dose equivalents received by individuals who may inadvertently intrude into the facility after the loss of active institutional control (100 years) will not exceed $100 \mathrm{mrem} / \mathrm{yr}$ for continuous exposure or 500 mrem for a single acute exposure." Like the NRC, the DOE inadvertent intruder performance objective is based on a hypothetical scenario, not an expected scenario. The scenario is intended to be used as a design mechanism to ensure that disposal facility designers provide defense-in-depth design

c. See discussion and definition of the term "effective dose equivalent" in Section 4.6. 
considerations regarding long-term waste stability. The waste should provide acceptable characteristics under potential future environmental and administrative control conditions.

To demonstrate that the site meets the performance objectives, each site is directed by the order to prepare and maintain a site-specific radiological PA for the disposal of waste with the purpose of demonstrating compliance with the performance objectives. Guidance for preparation of DOE performance assessments is provided by a Performance Assessment Task Team established by DOEHQ. A formal review of the PA is performed by a DOE-HQ established PA Peer Review Panel prior to being submitted to DOE-HQ for authorization for disposal. The Order requires sites to use monitoring measurements, where practical, to evaluate actual and prospective performance and to evaluate and modify the models used in the PA.

DOE Order 6430.1, General Design Criteria, was updated in April 1989 to include design requirements that support DOE Order 5820.2A, including guidelines for siting and design of LLW disposal facilities. The order reinforces the requirement that LLW disposed underground should be confined by a site-specific system of barriers that take into account waste form, waste packaging, and geologic setting. The order emphasizes that means be provided to minimize contact of emplaced LLW with water.

Like the NRC, DOE uses both prescriptive technical requirements and performance objectives to establish "defense-in-depth" barriers in the disposal system. Performance objectives and technical requirements for LLW disposal are found in DOE Order 5820.2A, Chapter III. DOE has issued a number of documents that identify applicable prescriptive requirements for LLW disposal operations. These include environmental impact statements, PAs, safety analysis reports, technical safety requirements, and waste acceptance criteria. The following is a list of significant LLW disposal topics and the DOE order(s) in which applicable requirements can be found:

- Disposal site suitability requirements-DOE Order 5820.2A, Radioactive Waste Management and DOE Order 6430.1A, General Design Criteria

- $\quad$ Site design requirements-DOE Order 5820.2A, Radioactive Waste Management and DOE Order 6430.1A, General Design Criteria

- Operational requirements-DOE Order 5820.2A, Radioactive Waste Management and DOE Order 5480.19, Conduct of Operations Requirements For DOE Facilities

- Closure requirements-DOE Order 5820.2A, Radioactive Waste Management

- Requirements for waste classification-DOE Order 5820.2A, Radioactive Waste Management

d. At the time of this writing, DOE is implementing two new orders, DOE Order 420.1, Facility Safety, and DOE Order 430.1, Life Cycle Asset Management, which will supersede DOE Order 6430.1A. DOE Order 6430.1A is applicable to all DOE sites until the site contracts are changed to reflect the new orders. The new orders contain no specific design requirements for LLW disposal facilities. 
- Prohibitions and limits related to the form of the waste-DOE Order 5820.2A, Radioactive Waste Management

- Environmental monitoring-DOE Order 5820.2A, Radioactive Waste Management, DOE Order 6430.1A, General Design Criteria, DOE Order 5400.1, General Environmental Protection Program, and DOE Order 5400.5, Radiation Protection of the Public and the Environment

- Institutional requirements-DOE Order 5820.2A, Radioactive Waste Management. 


\section{METHODOLOGY FOR COMPARISONS}

A DNFSB report, Low-Level Waste Disposal Policy for Department of Energy Defense Nuclear Facilities, ${ }^{6}$ organized radioactive waste disposal into five functional areas. These five areas and two additional categories (PA and approval requirements) were used as a basis for organizing the discussion of safety-related areas. The seven functional areas are siting, design, operations, closure, waste form, $\mathrm{PA}$ and approval requirements. Topics to be considered for comparison were then chosen for each of these functional areas. (An expanded listing of the topics is shown in Appendix A.) Disposal facility performance objectives are covered under the PA functional area.

The comparison was performed as two principal tasks:

1. Reviewing and listing for comparison the LLW disposal requirements, guidance, and practices of DOE, the U.S. non-DOE LLW disposal industry, and selected international documents.

2. Identifying differences in the requirements, guidance, and practices that may affect public or worker health and safety.

It was not practical to perform comparisons among all types of documents in the same way. Some comparisons were made line-by-line, using a recognized standard such as 10 CFR 61 as the primary reference. Others involved comparing requirements of various documents (such as facility waste acceptance criteria) for pre-established topics and looking for trends or gaps in the documents. Still other situations called for reading significant reference documents such as NRC Branch Technical Positions and acknowledging noteworthy practices for discussion in this report. Differences were identified when a requirement, guideline, or practice appeared different than another or if the comparison was complex enough to require further study.

The core requirements document for U.S. non-DOE LLW disposal operations is 10 CFR 61, "Licensing Requirements for Land Disposal of Radioactive Wastes." This Federal regulation establishes procedures, criteria, and terms and conditions upon which the NRC would issue licenses for the disposal of LLW. Similar requirements from 10 CFR 61 and DOE documents are grouped side by side and discussed in Appendix B of this report. The differences are addressed in Section 4 of this report. The main DOE document used for comparison is DOE Order 5820.2A.

Recently, memoranda have been issued by DOE-HQ that also apply to changes being made to DOE policy and requirements in response to the DNFSB Recommendation 94-2. A memorandum from the Deputy Assistant Secretary for Waste Management, Environmental Management, ${ }^{7}$ requires LLW PAs to include pre-1988 source terms and other sources of radioactive contamination in their analysis. Another memorandum, which establishes an interim DOE policy on oversight of LLW management and disposal, ${ }^{8}$ was issued by the Assistant Secretary for Environmental Management and the Assistant Secretary for Environment, Safety, and Health.

A comparison of waste acceptance criteria for the existing Barnwell and Richland non-DOE disposal facilities and for four DOE disposal facilities is shown in Appendix C. Topics used in the 
comparison were taken from a previous work, ${ }^{9}$ which compared the waste acceptance criteria of existing, former, and proposed non-DOE disposal facilities.

Appendix D contains DOE and non-DOE PA information gathered to determine if there are any differences in requirements, guidance, and practices. The information was separated into six tables:

- Table D-1-DOE PA requirements and guidance

- Table D-2-Non-DOE PA requirements and guidance

- Table D-3-DOE PA practices at the INEL's Radioactive Waste Management Complex (RWMC) and Hanford's 200 West Area

- Table D-4-DOE PA practices at Oak Ridge National Laboratory's (ORNL's) SWSA 6 and the Savannah River Site's E-Area Vaults

- Table D-5-Non-DOE PA practices in Texas, California, and Nebraska

- Table D-6-Non-DOE PA practices in North Carolina, Washington, and South Carolina.

The DOE PA documents used were those that have been completed in at least a draft form and reviewed by the PA Peer Review Panel. Most of these documents have not been approved. Because the work is continuing, the information is subject to change. 


\section{DIFFERENCES IN REQUIREMENTS, GUIDANCE, AND PRACTICES BASED ON COMPARISONS}

This section provides descriptions of apparent differences between DOE and non-DOE requirements, guidance, and practices for disposal of LLW. The authors have purposefully avoided drawing conclusions or making judgments or recommendations concerning if and how differences should be resolved, since that task is reserved for planned follow-on efforts. The differences are discussed under the following seven functional areas used to select safety-related topics: siting, design, operations, closure, waste form, PA, and approval and oversight.

\subsection{Siting}

Table B-1 in Appendix B compares the NRC siting requirements from 10 CFR 61 with those from DOE Orders 5820.2A and 6430.1A. The criteria for siting disposal facilities are similar; however, DOE is more constrained on potential site locations than commercial disposal facilities. The DOE disposal siting options are constrained by the locations of current DOE reservations, which were deemed as "appropriate" sites for nuclear activities at the time they were selected from national candidate sites. Non-DOE facilities generally begin site selection within the geographic boundaries of an entire state.

Since DOE establishes waste acceptance criteria for its sites on a site-specific basis, it has flexibility to restrict disposal of certain kinds of wastes from a disposal site if the site-specific PA concludes that the waste cannot be safely disposed at that site. For example, the INEL RWMC disposal facility will not accept LLW for disposal if it contains greater than $10 \mathrm{nCi} /$ gram transuranic activity. Non-DOE sites are sited to accept all class A, B, and C standardized waste forms. Thus, the DOE has more flexibility than the NRC to deem a disposal site as acceptable by imposing a site-specific restrictive waste acceptance criteria.

The document Comparative Approaches to Siting Low-Level Radioactive Waste Disposal Facilities $^{10}$ details the methods used by the various states to select site locations for disposal facilities. Most often these have included top-down screenings in which land area is eliminated from consideration in step-wise fashion by applying data that represent pre-established site selection criteria. Potential sites are those that remain after all the criteria have been applied. However, the report expresses reservations about these kinds of processes. Because top-down screening processes are presented as rigorous and scientific, shortcomings in the amount and quality of available screening data and professional differences over the importance of various site requirements have often been used to discredit the results. This then becomes a political as well as technical problem. Several non-DOE sites that have tried top-down screenings without success are now attempting more collaborative approaches to site selection. DOE has recently successfully faced the siting of new disposal facilities at sites such as the Hanford Environmental Remediation Disposal Facility with a public participation and review process involving a future land use planning activity. Future public participation in DOE activities may increase the level of attention to these issues. 


\subsection{Design}

Within and outside of DOE, a variety of designs are contemplated or in use for LLW disposal facilities. Tables 1 and 2 show current and planned disposal methods for DOE and non-DOE existing and planned facilities. As the tables show, disposal methods vary from traditional shallow land burial (open trench disposal) to use of near-surface disposal methods that utilize engineered barriers (such as vaults) to provide "greater confinement" for LLW disposal. ${ }^{e}$ The tables show that both non-DOE and DOE facilities utilize design concepts that incorporate engineered barriers to provide greater confinement of radionuclides beyond the confinement afforded by the waste form and site geologic characteristics. The use of the greater confinement barriers seems to be prevalent at more humid disposal sites.

Despite the favorable natural characteristics associated with several of the operating sites, most states have prohibited the use of shallow land burial techniques for future sites. The state prohibitions . on shallow land burial are primarily intended to make the facilities more publicly acceptable. ${ }^{11}$

Nebraska's law, for example, provides that:

No license for the operation of a facility shall be granted to any applicant who proposes a disposal design which uses traditional shallow land burial as used prior to 1979. The disposal cells of the facility shall be built above grade levels and designed to meet the state's zero-release objectives. (Nebraska Low-Level Radioactive Waste Disposal Act, Act 81-15, Section 101.02)

Other states that prohibit shallow land burial or that require the use of engineered barriers include Connecticut, New York, Pennsylvania, Ohio, North Carolina, and Illinois. Beginning in January 1996 South Carolina will also require vaults or equivalent barriers at the Barnwell disposal site.

Although the requirements of 10 CFR 61 were based on a hypothetical near-surface disposal facility in a humid environment, the NRC has maintained that the performance objectives and technical requirements in the regulation can be applied to a variety of disposal designs so long as the design objectives of 10 CFR 61 are met. In June 1993, the NRC amended 10 CFR 61.7 to state:

near-surface disposal includes disposal in engineered facilities which may be built totally or partially above-grade provided that such facilities have protective earthen covers.

e. The term "shallow land burial" refers to past methods of LLW waste disposal in which waste was placed in excavated pits or trenches and backfilled, capped, and mounded to facilitate water runoff. This method did not include use of engineered structures such as concrete vaults or concrete containers to provide additional confinement barriers to waste migration.

As defined in 10 CFR 61.7(a), "near-surface disposal" is a more encompassing term that includes both shallow land burial and engineered disposal facilities that may be built totally or partially aboveground, provided that such facilities have protective earthen covers. By definition these facilities must also involve disposal within the upper portion of the earths crust, approximately 30 meters. 
Table 1. DOE low-level waste disposal facility descriptions. ${ }^{\mathrm{a}}$

DOE site

Current disposal method

Hanford

Low-Level Burial Grounds

Shallow land burial ( $V$-trenches, wide bottom trenches)

Grout (emergency use only, planned vitrification facility replacement

Near-surface concrete vaults

Idaho National Engineering Laboratory

Shallow land burial (pits, trenches, soil vaults)

\section{Nevada Test Site}

Area 3

Shallow land burial in subsidence craters from underground nuclear tests

Area 5

Shallow land burial (pits, trenches, boreholes)

Los Alamos National Laboratory

MDA G

Shallow land burial (pits, 20-meter deep disposal shafts)

Oak Ridge Reservation

Solid Waste Storage Area 6

Above-grade tumulus

Savannah River Site

Saltstone

Grout in above-grade vaults (covered with soil, clay, and gravel earthen cap)

E-Area Vault

Above-grade concrete vaults (covered with soil, clay, and gravel earthen cap)

a. Source of table information: Framework for DOE Low-Level and Mixed Waste Disposal: Current Overview, DOE/ID10484, June 1994.

Table 2. Non-DOE current and planned low-level waste disposal facility descriptions.

\begin{tabular}{ll}
\hline Non-DOE site & \multicolumn{1}{c}{ Current or planned disposal method } \\
\hline California & $\begin{array}{l}\text { Shallow land burial in trenches at additional depth with } 5 \text { meters of fill over top of } \\
\text { waste }\end{array}$ \\
Nebraska & Above ground, earth-mounded concrete bunker \\
North Carolina & Above-grade, earth-mounded concrete vaults \\
South Carolina & Shallow land burial in trenches with waste in concrete overpacks \\
Texas & Shallow land burial in trenches with all waste in modular concrete containers \\
Washington & Shallow land burial in trenches \\
\hline
\end{tabular}


Thus, designers of facilities that must comply with state and NRC requirements have latitude in the design of engineered barriers for LLW disposal facilities. The PA, which is a part of the license application, documents that the overall disposal system, including the disposal facility, the site, and the waste form, meet regulatory performance objectives.

DOE also takes a non-prescriptive approach to setting disposal barrier requirements. Specific DOE LLW disposal facility design requirements are found in DOE Order 6430.1A. This order states that LLW that is disposed underground shall be confined by a site-specific system of barriers that may include, but not necessarily be limited to, waste form, waste packaging, and the geologic setting. Technical design personnel establish the detailed barrier requirements necessary to meet the performance objectives established in DOE Order 5820.2A. Compliance with DOE performance objectives is documented in the facility PA.

A significant difference between the DOE and the non-DOE LLW disposal design approaches is the fact that the NRC requires use of an LLW classification system and associated stability and disposal segregation requirements in 10 CFR 61, while DOE considers these as design parameters to be established on a site-specific basis. (Waste form requirements are further discussed in Section 4.5.)

The NRC requires that non-DOE disposal facilities dispose of Class $C$ waste "so that the top of the waste is a minimum of 5 meters below the top surface of the cover or must be disposed of with intruder barriers that are designed to protect against an inadvertent intrusion for at least 500 years" [10 CFR 61.52(a)(2)]. This requirement results from the fact that the waste classification and waste form stabilization requirements were driven by intruder scenario assumptions that included a five-meter burial depth assumption. The NRC did not establish a minimum depth requirement for Class A or B wastes.

The DOE did not establish a minimum depth requirement for its waste. The design of the method of waste stabilization, packaging, burial depth, and engineered barriers and covers for specific waste types and specific waste compositions is required to be developed through the PA on a site-specific basis. Some DOE sites require a minimum five-meter depth for higher activity wastes based on PA results.

\subsection{Operations}

A detailed comparison of disposal site operations, which might include staffing, dosimetry, emergency response, contingency plans, and other operational practices is beyond the scope of this report. Two aspects of site operations where differences between DOE and non-DOE practices are most apparent, recordkeeping and reporting and requirements for preventive measures in the event that radionuclide migration is detected, are discussed in the following paragraphs.

Subpart $G$ of 10 CFR 61 contains fairly detailed requirements for maintenance of records and reports for non-DOE LLW disposal operations. DOE Order 5820.2A, Chapter III, Section 3m, contains some less prescriptive information on maintenance of records for DOE LLW operations. Reporting requirements for environmental monitoring, similar to those in 10 CFR 61, Subpart G, are found in DOE Order 5400.1, Chapter II, Section 4. The DOE 1324 series of orders provided details 
on records management requirements for the DOE system. Therefore, the system of DOE orders provides similar requirements for records and reports as 10 CFR 61.

The DOE 1324 series of orders were recently reformatted and consolidated into one order, DOE Order 1324.5B, Records Management Program, dated January 12, 1995, whose only requirement for the heads of field elements is that they "shall develop and implement a records management program consistent with the requirements of Federal law, Code of Federal Regulations, DOE directives, DOE guidelines, and Departmentally established or accepted referenced standards." They must also "ensure that all records management program requirements are kept current and available for review." These requirements are not as prescriptive as the LLW recordkeeping requirements found in 10 CFR 61, which prescribe such things as acceptable record form (electronic, microform, or original records).

Unlike non-DOE operations [10 CFR 61.53(b)], DOE does not require the disposal facility to maintain plans for preventive measures if migration of radionuclides indicates that the performance objectives are not being met. DOE Order 5820.2A, Section $3 \mathrm{k}(4)$, requires that the monitoring program be capable of detecting changing trends in performance sufficiently in advance to allow application of any necessary corrective action prior to exceeding performance objectives.

\subsection{Closure}

DOE Order 5820.2A, Section 3j(1) states, "Field organizations shall develop site-specific comprehensive closure plans for new and existing operating LLW disposal sites. The plans shall address closure of disposal sites within a 5 year period after each disposal site is filled." In Section $3 \mathrm{j}(6)$, the Order states that termination of monitoring and maintenance activities at closed facilities shall be based on an analysis of site performance at the end of the institutional control period (normally 100 years). Thus, DOE takes the position that maintenance and monitoring of the site will be available, as necessary, until the end of the institutional control period. DOE is silent on passive controls after the institutional control period in DOE Order 5820.2A, but the Performance Assessment Task Team recommends that each analyst state and justify such a period on a site-specific basis. ${ }^{5}$

This approach is different from the NRC requirement in 10 CFR 61.29, which states that: "Following completion of closure authorized in Part 61.26, the licensee shall observe, monitor, and carry out necessary maintenance and repairs at the disposal site until the license is transferred by the Commission in accordance with Part 61.30. Responsibility for the site must be maintained by the licensee for 5 years. A shorter or longer time period for post-closure observation and maintenance may be established and approved as part of the site closure plan, based on site-specific conditions." Text in 10 CFR 61.7(c)(3) makes it clear that the five-year post-closure observation and maintenance period ensures that the disposal site is stable and ready for institutional control.

At the end of this five-year period, the licensee applies for a transfer of the license to the disposal site owner (a Federal or state agency). Transfer of the license requires that any funds and necessary records for care will be transferred to the disposal site owner [10 CFR 61.30(3)]. Thus, it is the position of the NRC that maintenance of the site during the institutional control period should not be necessary but would be performed as required. The planned period of institutional control is determined by the state; it cannot be less than 100 years. Active institutional controls may not be relied upon to limit access by the public to the site for over 100 years (10 CFR 61.59). Following the 
institutional control period the license is terminated by the Commission and permanent monuments or markers warning against intrusion are installed. Passive barriers are designed to protect against inadvertent intrusion for at least 500 years (10 CFR 61.52).

\subsection{Waste Form}

\subsubsection{Waste Stabilization}

One difference was found in the emphasis placed by the NRC and DOE on waste stabilization. DOE Order 6430.1A places primary confinement reliance on the geological properties of the site and augments these with waste form characteristics and engineered barriers, as necessary. Thus, DOE establishes waste form stabilization requirements based on site-specific technical analysis and PA. The NRC has taken the position that waste form should play a significant role in the overall plan for managing LLW and requires that some wastes have structural stability, independent of any site-specific considerations. $10 \mathrm{CFR} 61.56$ (b)(1) states that structural stability can be provided by the waste form itself, by processing the waste to a stable form, or by placing the waste in a disposal container or structure that provides stability after disposal. The NRC Technical Position on Waste Form ${ }^{12}$ describes acceptable methods of accomplishing waste stability, which includes mandatory stabilization of Class B and $C$ wastes and the use of high-integrity containers. Thus, the primary difference is that the NRC imposes mandatory waste form stability requirements on all disposal sites, while DOE imposes stability requirements on a site-specific basis, as deemed necessary by technical analysis.

State agencies that regulate non-DOE LLW disposal have adopted the practice of approving the use of specific products as part of the operating licenses for disposal facilities. ${ }^{13,14,15}$ These include solidification, stabilization, sorbent media, and waste containers (including high-integrity containers). Some DOE sites specify approved products and processes for solidification, stabilization, or absorbent media in their waste acceptance criteria.

In a comparison of waste acceptance criteria of DOE and NRC facilities (see Appendix C), the authors noted that state licensed facilities typically impose waste form requirements on incinerator ash as a licensing condition (no NRC requirement was found regarding incinerator ash or particulate immobilization requirements). It was also noted that the NRC has stability requirements for dewatered resins which are typically imposed as a license condition. Some DOE site waste acceptance criteria do not specifically address stability requirements for these two waste forms, which may be less common among DOE waste streams. The observation seems to be consistent with the DOE practice of establishing waste form stability requirements based on site-specific concerns.

\subsubsection{Waste Classification}

The NRC subclassifies LLW into Class A, B, or C (see 10 CFR 61.55). LLW that exceeds Class $\mathrm{C}$ levels is considered generally unsuitable for near-surface disposal by both DOE and the NRC. These classifications are used to determine the relative short- and long-term hazards of the waste form and as a basis for establishing stabilization requirements.

DOE Order 5820.2A specifies that disposition of waste designated as greater-than-Class $\mathrm{C}$ (as defined in 10 CFR 61.55), must be handled as special cases. Disposal systems for such waste must be 
justified by a specific PA, through the NEPA process, and with the concurrence of DOE-HQ. As a result of this requirement no DOE LLW disposal site is disposing of any DOE-equivalent GTCC waste.

DOE Order 5820.2A also designates that waste with transuranium radionuclides in concentrations of greater than $100 \mathrm{nCi} /$ gram shall be designated as transuranic (TRU) waste; all DOE TRU waste will be placed in interim storage and, later, disposed of in a deep geologic disposal facility, the Waste Isolation Pilot Plant (WIPP) in New Mexico.

The DOE does not specify subclasses of LLW on a standardized or system-wide basis, as is done in the NRC Class A, B, C system. However, LLW classification requirements may be imposed by each DOE site in their waste acceptance criteria. Each site implements requirements for waste classification as deemed necessary to segregate the waste so that handling, stabilization, and disposal requirements can be imposed to meet disposal performance objectives. For instance, Hanford classifies its LLW as Category 1 or 3 wastes based on an activity limits table; Category 3 . waste requires stabilization. The waste acquisition criteria for Savannah River E-Area vaults places isotope-specific limits on waste received by the facility. Oak Ridge SWSA- 6 requires that generators identify and segregate waste into categories that include fissile waste material (based on a isotope limit table), very low activity waste, contact-handled solid low-level waste (SLLW), remote-handled SLLW, biological waste, asbestos waste, and naturally occurring and accelerator-produced radioactive material. The IAEA safety guide on classification of radioactive waste (see Reference 1) provides recommendations for a classification system based on safety-related aspects of radioactive waste disposal, which is similar to the approach taken by the NRC and specific DOE sites.

A comparison of DOE, NRC, and IAEA classification systems is shown in Table 3. The IAEA and NRC classification systems have the following features that are not formally required by DOE:

- The Class $\mathrm{A}, \mathrm{B}$, and $\mathrm{C}$ designations used by the NRC provide a basis for categorizing waste according to relative short- and long-term hazards, based on activity levels and half-lives of radioactive constituents. Some DOE facilities use a similar classification system.

- The IAEA classification uses a designation of intermediate-level to indicate if the container's radiation exposure rate is greater than $200 \mathrm{mrem} / \mathrm{hr}$ at contact. This practice is similar to that for DOE TRU waste, where the waste is designated as remote-handled TRU (RH-TRU) and contact-handled TRU (CH-TRU). All DOE LLW disposal facilities use a radiation limit to differentiate between remote-handled or contact-handled LLW, but there is no formal recognition of the practice in the DOE orders.

- The IAEA classification uses a thermal power level $\left(2 \mathrm{~kW} / \mathrm{m}^{3}\right)$ quantitative discriminator to differentiate between LLW and HLW. Federal Law defines HLW for the NRC and the DOE.

Non-DOE LLW disposal sites are required to use the NRC classification system to establish waste stabilization requirements (10 CFR 61.55 and 56). Although not required, some DOE sites have designated and use a site-specific LLW classification system. DOE Order 5820.2A, Section 3i(2), states that site-specific waste classification limits may be developed if operationally useful in determining how specific wastes should be stabilized and packaged for disposal. 
Table 3. Comparison of DOE, NRC, and IAEA waste classification systems.

\begin{tabular}{|c|c|c|c|c|c|c|}
\hline \multicolumn{2}{|r|}{ IAEA } & \multicolumn{2}{|r|}{ DOE } & \multicolumn{2}{|r|}{ NRC } & \multirow[b]{2}{*}{ Comments } \\
\hline Waste class & Typical characteristics & Waste class & Typical characteristics & $\begin{array}{l}\text { Waste } \\
\text { class }\end{array}$ & Typical characteristics & \\
\hline Exempt Waste & $\begin{array}{l}\text { Activity levels below clearance } \\
\text { levels based on an annual dose to } \\
\text { public }<0.01 \mathrm{mSv} \text { ( } 1 \mathrm{mrem}) \text {. }\end{array}$ & $\begin{array}{l}\text { Nonradioactive } \\
\text { waste }\end{array}$ & $\begin{array}{l}\text { No volume contamination } \\
\text { added by nuclear operations. } \\
\text { Surface contamination levels } \\
\text { for release of materials are } \\
\text { provided in DOE } 5400.5 \text {, } \\
\text { Figure IV-1 and the } \\
\text { contamination must be } \\
\text { subjected to the ALARA } \\
\text { process. There is no } \\
\text { guidance for release of } \\
\text { volume contaminated } \\
\text { material. Such material may } \\
\text { be released if criteria and } \\
\text { survey techniques are } \\
\text { approved by EH-1. }\end{array}$ & $\begin{array}{l}\text { Exempt } \\
\text { waste }\end{array}$ & $\begin{array}{l}\text { The NRC has exempted } \\
\text { certain non-DOE products } \\
\text { from disposal as LLW, but } \\
\text { does not have generally } \\
\text { applicable standards for } \\
\text { evaluating requests for } \\
\text { exemptions. }\end{array}$ & None \\
\hline $\begin{array}{l}\text { LLW-Short } \\
\text { Lived }\end{array}$ & $\begin{array}{l}\text { Long-lived alpha-emitting } \\
\text { radionuclides }<4,000 \mathrm{~Bq} / \mathrm{g} \\
(108 \mathrm{nCi} / \mathrm{g}) \text { in individual waste } \\
\text { packages and }<400 \mathrm{~Bq} / \mathrm{g} \\
(11 \mathrm{nCi} / \mathrm{g}) \text { overall average. No } \\
\text { shielding required for normal } \\
\text { handling and transportation. }\end{array}$ & LLW & $\begin{array}{l}\text { Waste that is not HLW or } \\
\text { TRU waste. }\end{array}$ & $\begin{array}{l}\text { Low- } \\
\text { level } \\
\text { Class A, } \\
\text { B, or C } \\
\text { waste }\end{array}$ & $\begin{array}{l}\text { Waste with radionuclide } \\
\text { concentrations. } \\
\text { corresponding to levels } \\
\text { given in Tables } 1 \text { and } 2 \text { of } \\
10 \text { CFR } 61.55 \text {. }\end{array}$ & $\begin{array}{l}\text { Neither DOE nor NRC classification } \\
\text { identifies the contact gamma } \\
\text { radiation levels of the LLW package } \\
\text { as done by the IAEA. The DOE } \\
\text { classification for TRU waste, and } \\
\text { some DOE LLW sites, includes a } \\
\text { remote- or contact-handled } \\
\text { designator to indicate the shielding } \\
\text { and special handling considerations } \\
\text { associated with the waste package. } \\
\text { The radiation level of the package } \\
\text { gives some relative indication of the } \\
\text { gamma activity in the package. }\end{array}$ \\
\hline $\begin{array}{l}\text { LLW-Long } \\
\text { Lived }\end{array}$ & $\begin{array}{l}\text { Long-lived alpha-emitting } \\
\text { radionuclides }>4,000 \mathrm{~Bq} / \mathrm{g} \\
(108 \mathrm{nCi} / \mathrm{g}) \text { in individual waste } \\
\text { packages and }>400 \mathrm{~Bq} / \mathrm{g} \\
(11 \mathrm{nCi} / \mathrm{g}) \text { overall average. No } \\
\text { shielding required for normal } \\
\text { handling and transportation. }\end{array}$ & CH-TRU & $\begin{array}{l}>100 \mathrm{nCi} / \mathrm{g} \text { TRU waste } \\
\text { activity. Contact dose rate } \\
<200 \mathrm{mrem} / \mathrm{hr}-\text { no shielding } \\
\text { required for normal handling } \\
\text { and transportation. Some } \\
\text { DOE facilities also manage } \\
\text { waste containing other alpha } \\
\text { radionuclides as TRU waste. }\end{array}$ & $\begin{array}{l}\text { Greater- } \\
\text { Than- } \\
\text { Class-C } \\
\text { waste }\end{array}$ & $\begin{array}{l}\text { Waste with radionuclide } \\
\text { concentrations exceeding } \\
\text { the levels given in Table } 1 \\
\text { of } 10 \text { CFR } 61.55 \text { and is not } \\
\text { generally acceptable for } \\
\text { near-surface disposal. }\end{array}$ & \\
\hline
\end{tabular}


Table 3. (continued).

\begin{tabular}{|c|c|c|c|c|c|c|}
\hline \multicolumn{2}{|r|}{ IAEA } & \multicolumn{2}{|r|}{ DOE } & \multicolumn{2}{|r|}{ NRC } & \multirow[b]{2}{*}{ Comments } \\
\hline Waste class & Typical characteristics & Waste class & Typical characteristics & $\begin{array}{l}\text { Waste } \\
\text { class }\end{array}$ & Typical characteristics & \\
\hline $\begin{array}{l}\text { Intermediate } \\
\text { Level } \\
\text { Waste-Short } \\
\text { Lived }\end{array}$ & $\begin{array}{l}\text { Long-jjved alpha-emitting } \\
\text { radionuclides }<4,000 \mathrm{~Bq} / \mathrm{g} \\
(108 \mathrm{nCi} / \mathrm{g}) \text { in individual waste } \\
\text { packages and }<400 \mathrm{~Bq} / \mathrm{g} \\
(11 \mathrm{nCi} / \mathrm{g}) \text { overall average. } \\
\text { Contact dose rate }>200 \\
\text { mrem } / \mathrm{hr}-\text { shielding required for } \\
\text { normal handling and transportation. } \\
\text { Thermal power }<2 \mathrm{~kW} / \mathrm{m}^{3} \text {. }\end{array}$ & LLW & $\begin{array}{l}\text { Waste that is not HLW or } \\
\text { TRU waste. }\end{array}$ & $\begin{array}{l}\text { Low- } \\
\text { level } \\
\text { Class B } \\
\text { or } \mathrm{C} \\
\text { waste }\end{array}$ & $\begin{array}{l}\text { Waste with radionuclide } \\
\text { concentrations } \\
\text { corresponding to levels } \\
\text { given in Tables } 1 \text { and } 2 \text { of } \\
10 \text { CFR } 61.55 \text {. }\end{array}$ & $\begin{array}{l}\text { Many DOE sites impose site-specific } \\
\text { classification systems which quantify } \\
\text { the long- and short-term hazards of } \\
\text { its LLW. }\end{array}$ \\
\hline $\begin{array}{l}\text { Intermediate } \\
\text { Level } \\
\text { Waste-Long } \\
\text { Lived }\end{array}$ & $\begin{array}{l}\text { Long-lived alpha-emitting } \\
\text { radionuclides }>4,000 \mathrm{~Bq} / \mathrm{g} \\
(108 \mathrm{nCi} / \mathrm{g}) \text { in individual waste } \\
\text { packages and }>400 \mathrm{~Bq} / \mathrm{g} \\
(11 \mathrm{nCi} / \mathrm{g}) \text { overall average. } \\
\text { Contact dose rate }>200 \\
\text { mrem } / \mathrm{hr}-\text { shielding required for } \\
\text { normal handing and transportation. } \\
\text { Thermal power }<2 \mathrm{~kW} / \mathrm{m}^{3} \text {. }\end{array}$ & RH-TRU & $\begin{array}{l}>100 \mathrm{nCi} / \mathrm{g} \text { TRU waste } \\
\text { activity. Contact dose rate } \\
>200 \mathrm{mrem} / \mathrm{hr}-\text { shielding } \\
\text { required for normal handling } \\
\text { and transportation. }\end{array}$ & $\begin{array}{l}\text { Greater- } \\
\text { Than- } \\
\text { Class-C } \\
\text { waste }\end{array}$ & $\begin{array}{l}\text { Waste with radionuclide } \\
\text { concentrations exceeding } \\
\text { levels given in Table } 1 \text { of } \\
10 \text { CFR } 61.55 \text { and is not } \\
\text { generally acceptable for } \\
\text { near-surface disposal. }\end{array}$ & \\
\hline HLW & $\begin{array}{l}\text { Thermal power }>2 \mathrm{~kW} / \mathrm{m}^{3} \text {. Long- } \\
\text { lived alpha-emitting radionuclides } \\
>4,000 \mathrm{~Bq} / \mathrm{g}(108 \mathrm{nCi} / \mathrm{g}) \text { in } \\
\text { individual waste packages and } \\
>400 \mathrm{~Bq} / \mathrm{g}(11 \mathrm{nCi} / \mathrm{g}) \text { overall } \\
\text { average. }\end{array}$ & HLW & $\begin{array}{l}\text { Waste material that results } \\
\text { from the reprocessing of } \\
\text { spent nuclear fuel, including } \\
\text { liquid waste produced directly } \\
\text { in reprocessing and any solid } \\
\text { waste derived from the liquid, } \\
\text { that contains a combination of } \\
\text { transuranic waste and fission } \\
\text { products in concentrations } \\
\text { tequiring permanent isolation. }\end{array}$ & HLW & $\begin{array}{l}\text { (1) Irradiated reactor fuel, } \\
\text { (2) liquid wastes resulting } \\
\text { from the operation of the } \\
\text { first-cycle solvent } \\
\text { extraction system, or } \\
\text { equivalent, and the } \\
\text { concentrated wastes from } \\
\text { subsequent extraction } \\
\text { cycles, or equivalent, in a } \\
\text { facility for reprocessing } \\
\text { irradiated reactor fuel, and } \\
\text { (3) solids into which such } \\
\text { liquid wastes have been } \\
\text { converted. }\end{array}$ & $\begin{array}{l}\text { The DOE and NRC do not have a } \\
\text { quantitative value, such as the } \\
2 \mathrm{~kW} / \mathrm{m}^{3} \text { level, to designate the point } \\
\text { when waste is no longer considered } \\
\text { HLW. }\end{array}$ \\
\hline
\end{tabular}




\subsection{Performance Assessment}

The comparisons of the PA requirements, guidance, and practices are shown in Appendix D. The comparison tables provide a summary of the requirements and guidelines of the NRC. They also provide supplemental information of PA practices in Texas, California, Nebraska, North Carolina, and Washington. Of these facilities, only the Richland, Washington, facility is currently operating. The Barnwell, South Carolina, non-DOE facility is also an operating disposal site; however, detailed information from that site was not supplied for this report. The DOE disposal facilities covered are located in Idaho, Washington, South Carolina, and Tennessee.

Differences in the PA requirements, guidance, and practices of DOE and non-DOE disposal facilities are as follows:

1. Approval of the PA for new non-DOE disposal facilities is part of the license application review process. DOE Order $5820.2 \mathrm{~A}$ does not specify processes for approving and maintaining PAs. However, an interim DOE policy on oversight of LLW management and disposal, issued on July 21, 1995 (see Reference 8), provides specific procedures for approval of PAs and issuance of disposal authorization statements that set requirements for ensuring compliance with LLW disposal facility performance objectives.

2. The NRC and DOE use different dose systems in regulating potential radiation exposures of members of the public and hypothetical inadvertent intruders from disposal of low-level waste. The NRC uses the so-called critical organ approach to dose limitation recommended in Publication 2 of the International Commission on Radiological Protection (ICRP). ${ }^{17}$ In this approach, limits on dose equivalent ${ }^{\mathrm{f}}$ are established for the whole body and the critical organ, which usually is the organ receiving the highest dose. Thus the NRC expresses its performance objective for members of the public from low-level waste disposal in terms of limits on dose equivalent of 25 mrem per year to the whole body, 75 mrem per year to the thyroid, and 25 mrem per year to any other organ. The NRC also used higher dose limits to the whole body and the critical organ in establishing its waste classification system for nearsurface disposal, which is intended to provide protection of hypothetical inadvertent intruders. However, the DOE uses the more recent approach to dose limitation recommended in ICRP Publication 26, ${ }^{18,19}$ in which limits on dose equivalent to the whole

f. Dose equivalent is defined as the product of absorbed dose in rad (or gray) in tissue and a quality factor which takes into account differences in biological effectiveness between different types of radiation.. Dose equivalent is expressed in units of rem (or sievert). 
body and the critical organ are replaced by a single limit on effective dose equivalent. ${ }^{\mathrm{g}, \mathrm{h}}$ Thus, for members of the public, the DOE's performance objective for low-level waste disposal is expressed as a limit on effective dose equivalent of 25 mrem per year, and higher limits on effective dose equivalent also are used in the performance objective for protection of hypothetical inadvertent intruders.

3. Non-DOE PAs are not required to include calculations of dose to a hypothetical inadvertent intruder as is required of DOE PAs. The NRC does not require these calculations because the NRC waste classification system (waste Classes A, B, and C) is based on calculations of dose for a hypothetical inadvertent intruder scenario. DOE Order 5820.2A, Chapter III, Section $3 b(1)$, requires the PA to include calculations of effective dose equivalents to the inadvertent intruder to demonstrate compliance with the performance objectives given in DOE Order 5820.2A, Chapter III, Section 3a(3).

4. The NRC uses an allowable chronic dose equivalent limit to the inadvertent intruder of $500 \mathrm{mrem} / \mathrm{yr}$ to the whole body and bone or $1.5 \mathrm{rem} / \mathrm{yr}$ to any other organ, to establish concentration limits for LLW placed in near surface disposal facilities (see Reference 4). The DOE uses an allowable chronic effective dose equivalent of $100 \mathrm{mrem} / \mathrm{yr}$ for DOE sitespecific inadvertent intruder calculations [DOE Order 5820.2A, Chapter III, Section 3.a(3)]. The NRC increased the calculated upper limit for Class $C$ waste by a factor of 10 to allow for disposal of waste packages with above average concentrations of nuclides. This was done for consideration of peak-to-average waste concentrations and the low probability of contacting the higher concentration waste. When calculating the dose to the inadvertent intruder the DOE PAs assume that the buried waste is homogeneously mixed. There is no DOE policy or guidance (for a site that develops a site-specific waste classification system) to allow the use of a similar factor of 10 to establish the maximum concentration of a radionuclide that may be disposed.

5. The NRC requires that non-DOE disposal facilities protect an inadvertent intruder from coming into contact with disposed Class C LLW with an intruder barrier or a 5-meter cover [see 10 CFR 61.52(a)(2)]. DOE establishes barrier requirements based on engineering calculations made in the PA. DOE Order 5820.2A, Section $3 \mathrm{i}(2)$, states that engineered modifications for specific waste types and compositions for each disposal site shall be developed through the PA model.

g. Effective dose equivalent is defined as the sum over specified tissues of the products of the dose equivalent in a tissue (T) and the weighting factor for that tissue $\left(w_{\mathrm{T}}\right)$, i.e., $H_{\mathrm{E}}=\Sigma w_{\mathrm{T}} H_{\mathrm{T}}$. The effective dose equivalent is the sum of the effective dose equivalent received from external exposure, which normally is essentially the same as the dose equivalent to the whole body, and the committed effective dose equivalent from internal exposure. The weighting factors $w_{\mathrm{T}}$ are specified in ICRP Publication 26 and are intended to be proportional to the risk of stochastic health effects (i.e., fatal cancers or severe hereditary effects) per unit dose equivalent in the specified tissues. Thus, effective dose equivalent is intended to be proportional to stochastic risk for either uniform or nonuniform irradiations of the whole body. Effective dose equivalent is expressed in units of rem (or sievert).

h. DOE Order 5820.2A incorrectly specifies limits on "committed effective dose equivalent" for exposures of inadvertent intruders, which would exclude external dose. The Performance Assessment Task Team identified this problem and has provided guidance that the allowable doses are to be expressed as effective dose equivalents (see Reference 5). 
6. Neither the NRC nor DOE has established specific guidance on estimating inventories of previously buried wastes (although these wastes must be included in PAs) or on how to proceed in the event that credible estimates are not possible. This promises to be an issue because of the recent DOE memorandum (see Reference 7) that requires inclusion of pre-1988 waste in the PA source term.

\subsection{Approval and Oversight}

Differences exist between DOE and non-DOE LLW disposal facilities in the processes by which operational approval is granted and adherence to requirements is ensured.

\subsubsection{Operational Approval}

For the purposes of this report, operational approval is defined as the official authorization for a proposed facility to begin accepting waste for disposal or for an existing facility to continue accepting waste. Official authorization to operate implies a chain of organizational responsibility for the decision. Outside DOE, states may elect to become Agreement States by establishing regulatory programs functionally equivalent to those of the NRC. These programs are subject to periodic audit by the NRC; during these audits any shortcomings are noted and required to be corrected.

4.7.1.1 Approval for Construction. Before construction of a new non-DOE disposal facility may begin, a license application must be filed and a license obtained for the facility. The license application must contain specific technical information outlined in 10 CFR 61.10. The application must undergo a comprehensive review by the NRC or Agreement State agency to confirm that the proposed facility is expected to meet performance objectives and technical requirements in the 10 CFR 61 regulations. These reviews can take several years and cost several million dollars. Because the application review process is extensive, states invariably rely on the services of specialized contractors to make recommendations in areas that require detailed scientific and technical analysis.

The license is issued by the governing agency after a finding that the issuance of the license will not be inimical to the common defense and security and will not constitute unreasonable risk to the health and safety of the public, and provided that all standards established in 10 CFR 61.23 are satisfied. If the NRC were to issue a license rather than an Agreement State, the NRC would have to prepare an EIS in accordance with 10 CFR 51, Subpart A; the EIS assesses the impacts of a decision to approve the application. Some Agreement States also have statutes requiring an EIS for LLW disposal activities.

The operational approval process for proposed DOE LLW disposal facilities has some elements in common with the state processes. DOE Order 5820.2A requires field organizations with disposal sites to prepare and maintain a site-specific radiological PA for the disposal of waste with the purpose of demonstrating compliance with the radiological performance objectives in the order. For new DOE LLW disposal facilities, PAs are reviewed by the responsible field element and submitted to the Deputy Assistant Secretary (DAS) for Waste Management before construction begins. Recent DOE guidance (see Reference 8) establishes policy for review and approval of disposal facility PAs, which are reviewed by a peer review panel (PRP) at the request of the DAS for Waste Management. The purpose of this review is to ensure consistency and technical quality throughout the DOE complex in the development and application of performance assessment models that include site-specific 
geohydrology and waste composition. The PRP is selected by the DAS for Waste Management and is composed of DOE, contractor, and other specialists in PAs, with participation by representatives of the Office of Environment, Safety, and Health, and operations offices.

Documentation from the PRP review accompanies the PA, as well as other information, as needed, that assesses disposal facility performance (such as the closure plan and safety analysis report for the disposal facility). Waste Management staff evaluate the PA and PRP reviews, consult with the Office of Environment, Safety, and Health; and make a recommendation to the Assistant Secretary For Environmental Management regarding compliance with the performance objectives of DOE Order 5820.2A. The Assistant Secretary for Environmental Management decides whether or not to authorize construction of the disposal facility. When construction is authorized, the DAS for Waste Management prepares a Disposal Authorization Statement that sets forth the conditions for design, construction, and operation of the disposal facility that are appropriate to ensure compliance with the LLW performance objectives.

DOE contractors are also required to obtain the Program Secretarial Officer (PSO) approval of Preliminary Safety Analysis Reports (PSARs) prior to undertaking procurement of materials and components, construction, and preoperational testing of DOE nuclear facilities. ${ }^{20}$ The PSAR is a document routinely prepared to document the adequacy of the safety basis for a new nuclear facility; it provides assurance that the facility can be constructed, operated, maintained, and shut down safely and in compliance with applicable laws and regulations. It differs from the PA in that it primarily deals with worker and public safety issues during routine and credible off-normal operational conditions, whereas the PA is concerned with providing a reasonable estimate that the facility will meet the performance objectives established in DOE Order 5820.2A.

4.7.1.2 Approval for Disposal. The operator of a state- or NRC-licensed facility may begin operations after construction if it meets all of the conditions and requirements of its license. The agency issuing the license has the right to perform inspections of the wastes, equipment, operations, and facilities and to have any tests performed that it deems appropriate or necessary for the administration of the regulations. The agency may obtain an injunction or other court order to prevent a violation of requirements in applicable acts, rules, regulations, and license conditions.

DOE contractors are required to submit the facility's Final Safety Analysis Reports (FSARs) to the PSO for approval and authorization to operate DOE nuclear facilities. This approval is required in addition to the approval of the PA and PSAR prior to the start of facility construction. FSARs document the adequacy of the safety basis and provide assurance that the facility can be operated, maintained, and shut down safely and in compliance with applicable laws and regulations. ${ }^{20}$ The National Environmental Policy Act Implementing Procedures (10 CFR 1021) requires DOE to normally prepare an EIS for all major system acquisitions posing a potential threat to the environment. Thus, the LLW disposal facility operation will be addressed by a sitewide or a site-specific EIS. Both the NRC and DOE requirements for an EIS implement Section 102(2) of NEPA. The DOE EIS process requires public hearings. The EIS is ultimately approved by DOE.

Startup and restart of DOE LLW disposal facilities requires the successful completion of an operational readiness review (ORR) as outlined in DOE Order 425.1, Startup and Restart of Nuclear Facilities (supersedes DOE Order 5480.31, Startup and Restart of Nuclear Facilities). The ORR consists of both a contractor review and a DOE review of the facility's readiness to operate. Upon 
completion of the ORR, a final report documents the results of the ORR and reaches a conclusion as to whether startup of the facility can proceed safely. Thus, the issuance of a Disposal Authorization Statement, approval of the FSAR, approval of an applicable EIS, and a favorable ORR are the equivalent of the non-DOE facility licensing process. A primary difference between the DOE and commercial facility operation is that the commercial license process is conducted and approved by an independent state or Federal agency, while the DOE operational approval is given by DOE, which is also responsible for operation of the facility.

4.7.1.3 Applicability of New Requirements to Existing Facilities. Another point of comparison is the applicability of newly adopted rules and requirements to LLW disposal facilities already operating. When 10 CFR 61 was issued in late 1982, three non-DOE-operated, state-licensed facilities had been operating for a number of years under pre-existing requirements. The "Statements of Consideration" that accompanied the final issuance of 10 CFR 61 (47 FR 57446, December 27, 1982) indicate that most of the rule was meant to apply to the pre-existing disposal sites:

(A comment received on the draft rule) touches upon a subject with broader implications, the phasing in of the Part 61 requirements, consistent with the ability of licensees, Agreement States, and applicants to make necessary changes to assure compliance.

The following sections and subparts will be considered a matter of compatibility for the Agreement States when the rule is adopted: Section 61.2, Definitions; Subpart C, Performance Objectives; Subpart D, Technical Requirements for Land Disposal; those portions of Subpart B that are necessary to implement the provisions of Subparts $C$ and $D$; Subpart $E$ requiring closure funding arrangements; and Section 20.311, Transfer for disposal and manifests...

Some technical issues related to applying the new rule do not appear to have been explicitly addressed. Prior to issuance of the rule there were no standard regulatory limits on the concentration level of radioactive waste that could be accepted for disposal (i.e., the classification tables in $10 \mathrm{CFR}$ 61.55). Because of this, waste found to be generally unsuitable for near surface disposal, because it would yield unacceptable doses to an inadvertent intruder (500 mrem/yr dose equivalent), had already been disposed in the pre-existing trenches. However, an environmental analysis of the Barnwell, South Carolina, facility done by the NRC in 1981, determined that doses to the most exposed member of the public from the site would be well within 15 mrem per year dose equivalent in spite of the presence of waste exceeding near-surface disposal limits. ${ }^{16}$ Richland, Washington has included its pre-1982 wastes in the performance assessment submitted with its closure plan currently in the review and approval process.

The issuance of DOE Order 5820.2A in 1988 raised similar issues of retroactivity within the DOE system. The order required that each disposal site meet an effective dose equivalent limit to a hypothetical member of the public, although the form and composition of waste in the earlier years of disposal were not required to meet the same criteria for acceptance. Moreover, detailed information about the characteristics of waste was not available to calculate such doses to the level of confidence generally expected by today's standards. DOE intended that pre-1988 waste would be dealt with under Comprehensive Environmental Response, Compensation, and Liability Act; therefore, DOE Order 5820.2A stated that "waste that has not been disposed of prior to issuance of this Order shall be 
managed on the schedule developed in the Implementation Plan to accomplish the following: ..." A recent DOE memorandum (see Reference 7) that requires inclusion of pre-1988 waste in the PA source term has been issued.

\subsubsection{Regulatory Oversight}

There are differences in the processes by which DOE and non-DOE LLW disposal facilities ensure ongoing compliance with regulations and guidance. Once a non-DOE disposal facility begins operating, the state agency that regulates the facility has authority to impose sanctions (including civil and criminal penalties or facility shutdown) in the event that noted deficiencies are not corrected. These are usually in the form of monetary fines or outright cancellation of the operator's privilege to accept waste. Under provisions of the NRC Agreement State Program, the state radiation protection programs are subject to periodic audit by the NRC to ensure that they are compatible with the NRC's own programs and that their programs and staff are sufficient. The failure to correct any deficiencies noted can result in forfeiture of the state regulatory functions back to the NRC, although no such remedy has been invoked in the 30-year history of the program.

Disposal facilities are subject to regulation and oyersight by various DOE offices. The Deputy Assistant Secretary for Waste Management (EM-30) is charged with carrying out Assistant Secretary for Environmental Management (EM-1) responsibilities for managing DOE waste management activities, developing and interpreting waste management policy, and issuing guidance to the field. The Assistant Secretary for Environment, Safety, and Health (EH-1) provides oversight and independent assessments of waste management operations. EMI and EH offices are organizationally independent, but both report to the Secretary of Energy. EM-30 requirements are implemented in the waste management facilities by DOE management and operating contractors through written operating procedures and documented training programs. DOE field office representatives oversee the contractor operations and utilize a system of contractor incentive fees to encourage compliance with requirements. EH-1 and EM-1 have shutdown authority for waste management operations if environment, safety, and health risks are judged to be unacceptable.

The DOE is presently assessing the appropriateness of continued self-regulation and the need for external regulation. The outcome of the DOE review of external regulation options and a DOE strategic alignment may impact the alternatives DOE will actually implement over the long term. The evaluation is being performed by the Advisory Committee on External Regulation of DOE Nuclear Safety. The committee is co-chaired by John Ahearne, Executive Director of Sigma Xi, the Scientific Research Society, and former Chairman of the NRC; and Gerald Scannell, President of the National Safety Council and former Assistant Secretary of Labor for the Occupational Safety and Health Administration. It consists of 25 members from five Federal agencies, state regulators, public interest groups, and nuclear utilities. The final report is scheduled to be released by the end of calendar year 1995. 


\subsubsection{Other Approvals}

A non-DOE license establishes a list of requirements that must be met to operate the facility. The DOE has multiple activities and documents that are designed to perform the same functions as the licensing process. These include preparing and gaining approval of the safety analysis report, technical safety requirements, PA, site monitoring plan, NEPA documentation, and operations procedures, and conducting an operational readiness review before beginning operations.

Table 4 shows approval authority requirements for various documents that must be completed before disposal operations can begin at DOE and U.S. non-DOE LLW disposal sites. The required documentation is grouped into categories, based on the function of the document. The table shows that DOE has approval authority of most of the documents, excluding Federal regulations. In both the DOE and non-DOE approval processes, the acceptance of the final product depends on technical justification. DOE operations are currently subject to some Federal regulations; however, a majority of DOE requirements are found in DOE orders. From the table, it can be concluded that DOE operations are largely self-governed and regulated while U.S. non-DOE disposal operations are governed and regulated by independent agencies of the Federal or state governments. Efforts are underway to codify many of the DOE orders. The codification of the orders makes DOE operations subject to civil and criminal penalties if requirements of the Federal regulations are not met.

Table 4. Categories of documentation for LLW disposal facilities.

\begin{tabular}{|c|c|c|c|c|c|}
\hline Category & $\begin{array}{c}\text { Category } \\
\text { description }\end{array}$ & $\begin{array}{l}\text { Non-DOE } \\
\text { requirements } \\
\text { document } \\
\end{array}$ & $\begin{array}{c}\text { Approval } \\
\text { level }\end{array}$ & DOE requirements document & Approval level \\
\hline A & $\begin{array}{l}\text { Federal and state } \\
\text { regulations and } \\
\text { standards }\end{array}$ & $\begin{array}{l}\text { Code of Federal } \\
\text { Regulations, state } \\
\text { regulations }\end{array}$ & $\begin{array}{l}\text { Federal or } \\
\text { state }\end{array}$ & $\begin{array}{l}\text { DOE Orders, Code of Federal } \\
\text { Regulations, state regulations }\end{array}$ & $\begin{array}{l}\text { Federal, state, } \\
\text { or DOE }\end{array}$ \\
\hline B & $\begin{array}{l}\text { Required safety. } \\
\text { envelope } \\
\text { reviewed and } \\
\text { imposed by } \\
\text { regulating bodies }\end{array}$ & License & State & $\begin{array}{l}\text { PA, safety analysis report, } \\
\text { technical safety requirements, } \\
\text { NEPA documentation (EIS), } \\
\text { Operational Readiness Review } \\
\text { (DOE Order 425.1), DOE } \\
\text { Interim Policy (Reference 8) }\end{array}$ & DOE \\
\hline C & $\begin{array}{l}\text { Technical } \\
\text { assessment }\end{array}$ & $\begin{array}{l}\text { License } \\
\text { application } \\
\text { technical review }\end{array}$ & State & PA & DOE \\
\hline D & $\begin{array}{l}\text { Technical } \\
\text { considerations }\end{array}$ & $\begin{array}{l}\text { NRC guidance } \\
\text { documents, NRC } \\
\text { technical position } \\
\text { papers, state } \\
\text { guidance }\end{array}$ & State & DOE guidance documents & DOE \\
\hline $\mathbf{E}$ & $\begin{array}{l}\text { Safety envelope } \\
\text { implementation }\end{array}$ & $\begin{array}{l}\text { Waste acceptance } \\
\text { criteria, standard } \\
\text { operating } \\
\text { procedures }\end{array}$ & $\begin{array}{l}\text { Private } \\
\text { operating } \\
\text { facility } \\
\text { contractor }\end{array}$ & $\begin{array}{l}\text { Waste acceptance criteria, } \\
\text { standard operating procedures }\end{array}$ & $\begin{array}{l}\text { DOE operating } \\
\text { facility } \\
\text { contractor }\end{array}$ \\
\hline
\end{tabular}




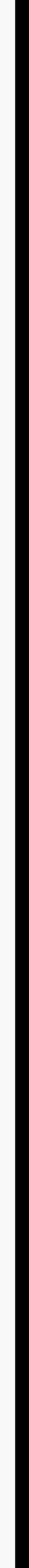




\section{REFERENCES}

1. International Atomic Energy Agency, 1994, Classification of Radioactive Waste, A Safety Guide, Safety Series No. 111-G-1.1, Vienna.

2. International Atomic Energy Agency, 1994, Siting of Near Surface Disposal Facilities, Safety Series No. 111-G-3.1, Vienna.

3. U.S. Nuclear Regulatory Commission, 1982, Final Environmental Impact Statement on 10 CFR Part 61 "Licensing Requirements for Land Disposal of Radioactive Waste," NUREG-0945, Volume 1, Office of Nuclear Material Safety and Safeguards, November, p. S-1.

4. U.S. Nuclear Regulatory Commission, 1981, Draft Environmental Impact Statement on 10 CFR Part 61 "Licensing Requirements for Land Disposal of Radioactive Waste," NUREG-0782, Volume 1, Office of Nuclear Material Safety and Safeguards, September, pp. 2-2 and 2-3.

5. Radioactive Waste Technical Support Program, 1994, Performance Assessment Task Team Progress Report, DOE/LLW-157, Revision 1, May.

6. Dominic S. Napolitano, Mark T. Sauterman, Monique V. Helfrich, Steven A. Stokes, 1994, Low-Level Waste Disposal Policy for Department of Energy Defense Nuclear Facilities, prepared by the Defense Nuclear Facilities Safety Board, September 14, transmitted by letter, John T. Conway to Hazel R. O'Leary, dated October 13.

7. Memorandum from J.E. Lytle to distribution, "Inclusion of Pre-1988 Source Term and Other Sources of Radioactive Contamination in Low-Level Waste Disposal Facility Performance Assessments," May 31, 1995.

8. Memorandum from T.P. Grumbly and T.J. O'Toole, "Interim Policy on Regulatory Structure for Low-Level Radioactive Waste Management and Oversight," July 21, 1995.

9. Thomas A. Kerr, 1995, Matrix and Cross-References for Current, Former, and Proposed/Suggested Low-Level Radioactive Waste Acceptance Criteria, National Low-Level Waste Management Program, Idaho National Engineering Laboratory, Lockheed Idaho Technologies Company, Revision 4, February 9.

10. William F. Newberry, 1994, Comparative Approaches to Siting Low-Level Radioactive Waste Disposal Facilities, DOE-LLW-199, Idaho National Engineering Laboratory, EG\&G Idaho, Inc., July.

11. R.L. Murray, 1994, Understanding Radioactive Waste, 4th edition, Richland: Battelle Press.

12. U.S. Nuclear Regulatory Commission, 1991, Technical Position on Waste Form, Low-Level Waste Management Branch, Division of Low-Level Waste Management and Decommission, Revision 1, January. 
13. State of Washington Radioactive Material License, US Ecology, Inc., License No. WN-I019-2, Amendment No. 18, expiration date May 31, 1997.

14. Nevada State Health Division Radioactive Material License, US Ecology, Inc., License No. 1311-0043-02, Amendment No. 13, expiration date May 31, 1992.

15. Draft California Radioactive Material License, US Ecology, Inc., License No. 4505-36 (not issued yet) June 14, 1991.

16. U.S. Nuclear Regulatory Commission, 1982, Environmental Assessment for the Barnwell LowLevel Waste Disposal Facility, NUREG-0879, January.

17. International Commission on Radiological Protection, 1959, Recommendations of the International Commission on Radiological Protection, Publication 2, Pergamon Press: New York.

18. International Commission on Radiological Protection, 1977, Recommendations of the International Commission on Radiological Protection, Publication 26, Pergamon Press: New York.

19. D.C. Kocher, 1988, Review of Radiation Protection and Environmental Radiation Standards for the Public, Nuclear Safety, Vol. 29, No. 4, October-December, pp. 463-475.

20. DOE Order 5480.23, Nuclear Safety Analysis Reports, U.S. Department of Energy, April 30, 1992. 


\section{Appendix A}

\section{Safety Related Topics for Comparison}




\section{Appendix A}

\section{Safety Related Topics for Comparison}

I. Approval and Oversight

II. Siting
A. Siting considerations
B. Site characterization

III. Design

A. Facility design and construction
a. Engineered cover
b. Drainage system
c. Intruder barriers

IV. Operations
A. Waste inspection and verification
B. Waste emplacement
a. Stacking
b. Compacting
c. Separation of waste classes
C. Environmental monitoring
D. Corrective measures

a. Required notifications for unusual occurrences

b. Operational startup/shutdown approval authority

E. Records, reports, tests, and inspections

V. Closure
A. Facility closure/institutional control

VI. Waste Form 
A. Waste classification system

B. Waste characteristics
a. Waste acceptance criteria
b. Waste characterization
c. Waste certification

C. Waste form and packaging
a. Waste stabilization
b. Acceptable packaging
c. Prohibited wasteforms

VII. Performance assessment
A. General

a. Format and content

1. What are the general format and content of the performance assessment?

b. Approval process

1. What is the formal process for final approval of the performance assessment?

c. Review process

1. What formal review process does the performance assessment go through before submittal for approval?

d. Performance assessment maintenance

1. Does the performance assessment need to be reviewed and updated if parameters change?

e. Method for evaluating uncertainty

1. Is the method deterministic or probabilistic, and what kind of uncertainty or sensitivity analysis is used?

f. Computer codes

1. Is there an approval process for performance assessment codes that is separate from the performance assessment approval process?

2. Does the code approval process include validation and/or verification? 
3. Is there a list of pre-approved codes?

B. Receptor (The topics and questions in this section apply to the most exposed individual. The same topics and questions are used in Section 3 as they apply to the inadvertent intruder.)

a. Receptor scenario

1. What general assumptions are required?

2. What site-specific assumptions are used?

3. Are variations used to model against possible future environmental conditions?

b. Dose standard

1. What is the dose standard (performance objective) for the most exposed individual?

c. Point of compliance

1. Where is the most exposed individual located with respect to the disposal site?

d. Time of Compliance

1. What is the time of compliance (time certain or peak dose)?

2. What assumptions are made about future land ownership/control?

3. What institutional control period is specified?

4. What assumptions are made about active and passive controls that may affect performance assessment results?

e. Dose conversion

1. What requirements or standards are used to determine dose conversion factors?

C. Receptor (The same questions used in Section 2 are repeated here, as they apply to the inadvertent intruder)

D. Release mechanism

a. Waste inventory

1. What are the requirements for keeping records on waste inventory?

2. How do current requirements for keeping records differ from past requirements?

3. Where past records are not up to today's standards, what is done to estimate waste inventory for purposes of the performance assessment? 
b. Source term

1. What assumptions are made about the release of radionuclides from the various waste forms?

2. For purposes of the performance assessment during operations or for closure, is all waste included in the source term?

4.2.3 What is the source of scaling factors for indirectly measured radionuclides?

E. Pathways

a. Site characteristics

1. Must data about site characteristics meet any quality requirements in order to be used in the performance assessment?

2. What requirements are there to avoid the potential for "masking" from nearby facilities?

b. Waste distribution

1. What assumptions are made about the distribution of waste in disposal units for calculating dose to the most exposed individual?

2. What assumptions are made about the distribution of waste in disposal units for calculating dose to a hypothetical inadvertent intruder? 
Appendix B

Comparison of NRC and DOE Disposal Requirements 
Table B-1. Comparison of DOE and NRC disposal requirements.

\begin{tabular}{|c|c|c|c|c|c|}
\hline Topic & NRC ref & Commercial requirement & DOE ref & DOE requirement & Discussion \\
\hline \multirow[t]{2}{*}{$\begin{array}{l}\text { License } \\
\text { requirements }\end{array}$} & \multirow[t]{2}{*}{10 CFR 61.3(b) } & \multirow[t]{2}{*}{$\begin{array}{l}\text { Each person shall file an application with } \\
\text { the Commission and obtain a license as } \\
\text { provided in this part before commencing } \\
\text { construction of a land disposal facility. } \\
\text { Failure to comply with this requirement } \\
\text { may be grounds for denial of a license. }\end{array}$} & $\begin{array}{l}\text { DOE Order } \\
5820.2 \mathrm{~A} \\
\text { Chapter III } \\
\text { 3.b.(1) }\end{array}$ & $\begin{array}{l}\text { Field organizations with disposal sites shall } \\
\text { prepare and maintain a site-specific } \\
\text { radiological performance assessment for the } \\
\text { disposal of waste for the purpose of } \\
\text { demonstrating compliance with performance } \\
\text { objectives. }\end{array}$ & $\begin{array}{l}\text { The DOE disposal authorization statement is } \\
\text { intended to serve a function similar to a } \\
\text { license although the scope is not as broad. } \\
\text { The DOE SAR, NEPA document, closure } \\
\text { plan, and operational readiness reviews } \\
\text { cover the remaining scope. }\end{array}$ \\
\hline & & & $\begin{array}{l}\text { Grumbly/ } \\
\text { O'Toole Interim } \\
\text { Policy Letter }\end{array}$ & $\begin{array}{l}\text { Headquarters elements review and approve } \\
\text { LLW disposal facilities performance } \\
\text { assessments, and issue disposal authorization } \\
\text { statements that set forth requirements } \\
\text { important for assuring compliance with } \\
\text { LLW disposal facility performance } \\
\text { objectives. }\end{array}$ & \\
\hline $\begin{array}{l}\text { License } \\
\text { requirements }\end{array}$ & 10 CFR 61.6 & $\begin{array}{l}\text { The commission may, upon application by } \\
\text { any interested person, or upon its own } \\
\text { initiative, grant any exemptions from the } \\
\text { requirements of the regulations in this part } \\
\text { as it determines is authorized by law, will } \\
\text { not endanger life or property, or ... }\end{array}$ & $\begin{array}{l}\text { DOE Order } \\
5480.31 \\
9 . \mathrm{b}(11)\end{array}$ & $\begin{array}{l}\text { There shall be a statement in each } \\
\text { Operational Readiness Review (ORR) final } \\
\text { report as to whether any identified } \\
\text { nonconformances with compliance with } \\
\text { applicable DOE Orders, Sec. of Energy } \\
\text { Notices, and Standards/Requirements } \\
\text { Identification Documents have been formally } \\
\text { approved. }\end{array}$ & $\begin{array}{l}\text { Both systems for operational approval } \\
\text { require formal approval of exemptions from } \\
\text { requirements. }\end{array}$ \\
\hline Siting & 10 CFR 61.7(a) & $\begin{array}{l}\text { In choosing a disposal site, site } \\
\text { characteristics should be considered in } \\
\text { terms of the indefinite future and evaluated } \\
\text { for at least a } 500-\mathrm{yr} \text { time frame. }\end{array}$ & $\begin{array}{l}\text { DOE Order } \\
5820.2 \mathrm{~A} \\
\text { Chapter III } \\
3 \mathrm{i}(7)(\mathrm{d})\end{array}$ & $\begin{array}{l}\text { The potential for natural hazards such as } \\
\text { floods, erosion, tornadoes, earthquakes, and } \\
\text { volcanoes shall be considered in site } \\
\text { selection. }\end{array}$ & $\begin{array}{l}\text { Both citations require consideration of } \\
\text { long-term site characteristics. }\end{array}$ \\
\hline Siting & 10 CFR 61.7(a) & $\begin{array}{l}\text { In choosing a disposal site, site } \\
\text { characteristics should be considered in } \\
\text { terms of the indefinite future and evaluated } \\
\text { for at least a } 500 \text {-yr time frame. }\end{array}$ & $\begin{array}{l}\text { DOE Order } \\
5820.2 \mathrm{~A} \\
\text { Chapter III } \\
3 \mathrm{i}(7)(\mathrm{e})\end{array}$ & $\begin{array}{l}\text { Site selection criteria shall address the } \\
\text { impact on current and projected populations, } \\
\text { land use resource development plans and } \\
\text { nearby facilities, accessibility to } \\
\text { transportation routes and utilities, and the } \\
\text { location of waste generation. }\end{array}$ & $\begin{array}{l}\text { Both citations require consideration of } \\
\text { long-term site characteristics. }\end{array}$ \\
\hline Design & $\begin{array}{l}10 \mathrm{CFR} \\
61.7(\mathrm{~b})(1)\end{array}$ & $\begin{array}{l}\text { Disposal of radioactive waste in } \\
\text { near-surface disposal facilities has the } \\
\text { following safety objectives: (1) Protection } \\
\text { of the general population from releases of } \\
\text { radioactivity, }\end{array}$ & $\begin{array}{l}\text { DOE Order } \\
5820.2 \mathrm{~A} \\
\text { Chapter III } \\
2 \mathrm{a}\end{array}$ & $\begin{array}{l}\text { DOE LLW operations shall be managed to } \\
\text { protect the health and safety of the public, } \\
\text { preserve the environment of the waste } \\
\text { management facilities, and ensure that no } \\
\text { legacy requiring remedial action remains } \\
\text { after operations has been terminated. }\end{array}$ & The intent of the citations is the same. \\
\hline
\end{tabular}


Table B-1. (continued).

\begin{tabular}{|c|c|c|c|c|c|}
\hline Topic & NRC ref & Commercial requirement & DOE ref & DOE requirement & Discussion \\
\hline Design & $\begin{array}{l}10 \mathrm{CFR} \\
61.7(\mathrm{~b})(1)\end{array}$ & $\begin{array}{l}\text { Disposal of radioactive waste in } \\
\text { near-surface disposal facilities has the } \\
\text { following safety objectives (2) Protection of } \\
\text { individuals from inadvertent intrusion. }\end{array}$ & $\begin{array}{l}\text { DOE Order } \\
5820.2 \mathrm{~A} \\
\text { Chapter III } \\
3 \mathrm{a}(3)\end{array}$ & $\begin{array}{l}\text { DOE LLW operations shall be managed to } \\
\text { 3) Ensure that the committed EDEs received } \\
\text { by individuals who inadvertently may intrude } \\
\text { into the facility after the loss of active } \\
\text { institutional control shall not exceed } \\
100 \mathrm{mrem} / \mathrm{yr} \text { for continuous exposure. }\end{array}$ & $\begin{array}{l}\text { Both documents identify the need for } \\
\text { protection of inadvertent intruders. }\end{array}$ \\
\hline Design & $\begin{array}{l}10 \mathrm{CFR} \\
61.7(\mathrm{~b})(1)\end{array}$ & $\begin{array}{l}\text { Disposal of radioactive waste in } \\
\text { near-surface disposal facilities has the } \\
\text { following safety objectives ( } 3 \text { ) Protection of } \\
\text { individuals during operations. }\end{array}$ & $\begin{array}{l}\text { DOE Order } \\
5480.23\end{array}$ & $\begin{array}{l}\text { All DOE operations must have approved } \\
\text { safety analysis reports (SARs) which cover } \\
\text { individual worker and public safety in detail. }\end{array}$ & $\begin{array}{l}\text { The DOE system covers worker safety in } \\
\text { great detail in their SARs. }\end{array}$ \\
\hline Design & $\begin{array}{l}10 \mathrm{CFR} \\
61.7(\mathrm{~b})(1)\end{array}$ & $\begin{array}{l}\text { Disposal of radioactive waste in } \\
\text { near-surface disposal facilities has the } \\
\text { following safety objectives (4) Ensure } \\
\text { stability of the site after closure. }\end{array}$ & $\begin{array}{l}\text { DOE Order } \\
5820.2 \mathrm{~A} \\
\text { Chapter III } \\
3 \mathrm{i}(7)(\mathrm{d})\end{array}$ & $\begin{array}{l}\text { Thic potential for natural hazards such as } \\
\text { floods, erosion, tornadoes, earthquakes, and } \\
\text { volcanoes shall be considered in site } \\
\text { selecțion. }\end{array}$ & $\begin{array}{l}\text { Both citations address long-term stability. } \\
\text { Waste form stability is specifically addressed } \\
\text { in later requirements. }\end{array}$ \\
\hline Design & $\begin{array}{l}10 \mathrm{CFR} \\
61.7(\mathrm{~b})(2)\end{array}$ & $\begin{array}{l}\text { The Class A waste will be disposed of in } \\
\text { separate disposal units at the disposal site. } \\
\text { However, Class A waste that is stable may } \\
\text { be mixed with other classes of wastes. } \\
\text { Those higher activity wastes that should be } \\
\text { stable for proper disposal are classed as } \\
\text { Class B and C waste. }\end{array}$ & $\begin{array}{l}\text { DOE Order } \\
5820.2 \mathrm{~A} \text {, } \\
\text { Chapter III } 3 \mathrm{i}(1) \\
\text { and (2) }\end{array}$ & $\begin{array}{l}\text { (1) LLW shall be disposed of by methods } \\
\text { appropriate to achieve the performance } \\
\text { objectives stated in para. 3a, consistent with } \\
\text { the disposal site radiological performance } \\
\text { assessment in para. 3b. } \\
\text { (2) Engineered modifications (stabilization, } \\
\text { packaging, burial depth, barriers) for } \\
\text { specific waste types and for specific waste } \\
\text { compositions (fission products, induced } \\
\text { radioactivity, uranium, thorium, radium) for } \\
\text { each disposal site shall be developed through } \\
\text { the PA. In the course of this process, site- } \\
\text { specific waste classification limits may be } \\
\text { developed if operationally useful in } \\
\text { determining how specific wastes should be } \\
\text { stabilized and packaged for disposal. }\end{array}$ & $\begin{array}{l}\text { DOE determines allowable disposal practices } \\
\text { for different types of waste on a } \\
\text { case-by-case basis, as determined by the } \\
\text { performance assessment. Waste } \\
\text { classification is a site-specific requirement } \\
\text { for DOE disposal sites. }\end{array}$ \\
\hline Waste Form & $\begin{array}{l}10 \text { CFR } \\
61.7(b)(2)\end{array}$ & $\begin{array}{l}\text { To the extent that it is practicable, Class B } \\
\text { and } C \text { waste forms or containers should be } \\
\text { designed to be stable, i.e., maintain gross } \\
\text { physical properties and identity, over } \\
300 \mathrm{yr} \text {. }\end{array}$ & $\begin{array}{l}\text { DOE Order } \\
5820.2 \mathrm{~A}, \\
\text { Chapter III 3i(2) }\end{array}$ & $\begin{array}{l}\text { In the course of this process, site-specific } \\
\text { waste classification limits may be developed } \\
\text { if operationally useful in determining how } \\
\text { specific wastes should be stabilized and } \\
\text { packaged for disposal. }\end{array}$ & $\begin{array}{l}\text { DOE determines allowable disposal practices } \\
\text { for different types of waste on a } \\
\text { case-by-case basis, as determined by the } \\
\text { facility design and performance assessment. } \\
\text { Therefore, stability considerations of waste } \\
\text { type disposal are considered. }\end{array}$ \\
\hline
\end{tabular}


Table B-1. (continued).

\begin{tabular}{|c|c|c|c|c|c|}
\hline Topic & NRC ref & Commercial requirement & DOE ref & DOE requirement & Discussion \\
\hline Design & $\begin{array}{l}10 \text { CFR } \\
61.7(b)(2)\end{array}$ & $\begin{array}{l}\text { For certain radionuclides prone to } \\
\text { migration, a maximum disposal site } \\
\text { inventory based on characteristics of the } \\
\text { disposal site may be established to limit } \\
\text { potential exposure. }\end{array}$ & $\begin{array}{l}\text { DOE Order } \\
5820.2 \mathrm{~A} \\
\text { Chapter III } \\
3 \mathrm{e}(5)\end{array}$ & $\begin{array}{l}\text { The waste acceptance criteria for storage, } \\
\text { treatment, or disposal facilities shall address } \\
\text { the following issues: (a) allowable } \\
\text { quantities/concentrations of waste-specific } \\
\text { radionuclides to be handled, processed, } \\
\text { stored or disposed of; (b) ... }\end{array}$ & $\begin{array}{l}\text { DOE determines allowable disposal practices } \\
\text { for waste based on a case-by-case basis in } \\
\text { the performance assessment. Therefore, } \\
\text { allowable inventories for radionuclides will } \\
\text { be established by the performance } \\
\text { assessment. }\end{array}$ \\
\hline Closure & $\begin{array}{l}10 \text { CFR } \\
61.7(b)(4)\end{array}$ & $\begin{array}{l}\text { Institutional control of access to the site is } \\
\text { required for up to } 100 \mathrm{yr} \text {. This permits the } \\
\text { disposal of Class } \mathrm{A} \text { and Class B waste } \\
\text { without special provisions for intrusion } \\
\text { protection, since these classes of waste } \\
\text { contain types and quantities ... }\end{array}$ & $\begin{array}{l}\text { DOE Order } \\
5820.2 \mathrm{~A} \\
\text { Chapter III } \\
\text { 3a(3) }\end{array}$ & $\begin{array}{l}\text { DOE LLW ... shall be managed to } \\
\text { (3) Ensure that the committed EDEs } \\
\text { received by individuals who inadvertently } \\
\text { may intrude into the facility after the loss of } \\
\text { active institutional control ( } 100 \mathrm{yr} \text { ) shall not } \\
\text { exceed } 100 \mathrm{mrem} / \mathrm{yr} \text {. }\end{array}$ & $\begin{array}{l}\text { The citations call for institutional control of } \\
\text { the site for at least } 100 \mathrm{yr} \text { after closure. The } \\
\text { performance assessment will address the } \\
\text { need for special provisions for intrusion } \\
\text { protection after institutional controls are } \\
\text { removed. }\end{array}$ \\
\hline Waste Form & $\begin{array}{l}10 \text { CFR } \\
61.7(b)(5)\end{array}$ & $\begin{array}{l}\text { Waste that will not decay to levels which } \\
\text { present an acceptable hazard to an intruder } \\
\text { within } 100 \mathrm{yr} \text { is designated as Class } \mathrm{C} \\
\text { waste. }\end{array}$ & $\begin{array}{l}\text { DOE Order } \\
5820.2 \mathrm{~A}, \\
\text { Chapter III 3i(2) }\end{array}$ & $\begin{array}{l}\text { In the course of this process, site-specific } \\
\text { waste classification limits may be developed } \\
\text { if operationally useful in determining how } \\
\text { specific wastes should be stabilized and } \\
\text { packaged for disposal. }\end{array}$ & $\begin{array}{l}\text { DOE does not designate the Class } \mathrm{C} \text { waste } \\
\text { category but the performance assessment } \\
\text { does look for long-term impacts on } \\
\text { intruders. Waste classification is a } \\
\text { site-specific criterion used if necessary to } \\
\text { ensure containment of long-lived } \\
\text { radionuclides and to assign unique intrusion } \\
\text { barrier requirements. }\end{array}$ \\
\hline Design & $\begin{array}{l}10 \text { CFR } \\
61.7(b)(5)\end{array}$ & $\begin{array}{l}\text { This waste is disposed of at greater depth } \\
\text { than the other classes of waste so that } \\
\text { subsequent surface activities by an intruder } \\
\text { will not disturb the waste. Where site } \\
\text { conditions prevent deeper disposal, intruder } \\
\text { barriers such as concrete covers may be } \\
\text { used. For Class C waste, where site } \\
\text { conditions prevent deeper disposal, intruder } \\
\text { barriers such as concrete covers may be }\end{array}$ & $\begin{array}{l}\text { DOE Order } \\
5820.2 \mathrm{~A}, \\
\text { Chapter III } 3 \mathrm{i}(2)\end{array}$ & $\begin{array}{l}\text { Engineered mods. (stabilization, packaging, } \\
\text { burial depth, barriers) for specific waste } \\
\text { types and for specific waste compositions } \\
\text { (fission products, induced radioactivity, } \\
\text { uranium, thorium, radium) for each disposal } \\
\text { site shall be developed through the PA. }\end{array}$ & $\begin{array}{l}\text { DOE does not designate the Class } C \text { waste } \\
\text { category but the performance assessment } \\
\text { does look for long-term impacts on intruders } \\
\text { and necessary provisions are made for } \\
\text { intrusion barriers. The design of intruder } \\
\text { barriers at DOE facilities is based on } \\
\text { performance assessment calculations and is } \\
\text { specific for each site. }\end{array}$ \\
\hline
\end{tabular}

used. The effective life of these intruder

barriers should be $500 \mathrm{yr}$. 
Table B-1. (continued).

\begin{tabular}{|c|c|c|c|c|c|}
\hline Topic & NRC ref & Commercial requirement & DOE ref & DOE requirement & Discussion \\
\hline Design & $\begin{array}{l}10 \mathrm{CFR} \\
61.7(\mathrm{~b})(5)\end{array}$ & $\begin{array}{l}\text { Waste with concentrations above Class } \mathrm{C} \\
\text { limits is generally unacceptable for } \\
\text { near-surface disposal. }\end{array}$ & $\begin{array}{l}\text { DOE Order } \\
5820.2 \mathrm{~A} \\
\text { Chapter III } 3 \mathrm{i}(4)\end{array}$ & $\begin{array}{l}\text { Disposition of waste designated as } \\
\text { Greater-Than-Class C (GTCC), as defined in } \\
10 \text { CFR } 61.55, \text { must be handled as special } \\
\text { cases. Disposal systems for such waste } \\
\text { must be justified by a specific performance } \\
\text { assessment through the NEPA process and } \\
\text { with the concurrence of DP-12 for all DP-1 } \\
\text { disposal facilities and NE-20 for those } \\
\text { disposal facilities under the cognizance of } \\
\text { NE-1. }\end{array}$ & $\begin{array}{l}\text { The } 10 \text { CFR requirement leaves room for } \\
\text { exceptions to this rule. DOE prescribes } \\
\text { methods for approving the exceptions. }\end{array}$ \\
\hline Design & $\begin{array}{l}10 \text { CFR } \\
61.7(b)(5)\end{array}$ & $\begin{array}{l}\text { There may be some instances where waste } \\
\text { with concentrations GTCC would be } \\
\text { acceptable for near-surface disposal with } \\
\text { special processing or design. These will be } \\
\text { evaluated on a case-by-case basis. }\end{array}$ & $\begin{array}{l}\text { DOE Order } \\
5820.2 \mathrm{~A} \text {, } \\
\text { Chapter III 3i(4) }\end{array}$ & $\begin{array}{l}\text { Disposition of waste designated as GTCC, as } \\
\text { defined in } 10 \text { CFR } 61.55 \text {, must be handled } \\
\text { as special cases. }\end{array}$ & $\begin{array}{l}\text { Both requirements acknowledge the need for } \\
\text { a case-by-case determination of the } \\
\text { acceptability of the waste for near-surface } \\
\text { disposal. }\end{array}$ \\
\hline Waste Form & $\begin{array}{l}10 \text { CFR } \\
61.7(b)(5)\end{array}$ & Class $\mathrm{C}$ waste must also be stable. & $\begin{array}{l}\text { DOE Order } \\
5820.2 \mathrm{~A}, \\
\text { Chapter III 3i(2) }\end{array}$ & $\begin{array}{l}\text { Engineered mods. (stabilization, packaging, } \\
\text { burial depth, barriers) for specific waste } \\
\text { types and for specific waste compositions } \\
\text { (fission products, induced radioactivity, } \\
\text { uranium, thorium, radium) for each disposal } \\
\text { site shall be developed through the PA. }\end{array}$ & $\begin{array}{l}\text { DOE addresses stability requirements base } \\
\text { on performance assessment calculations. }\end{array}$ \\
\hline Siting & $\begin{array}{l}10 \text { CFR } \\
61.7(c)(1)\end{array}$ & $\begin{array}{l}\text { During the preoperational phase, the } \\
\text { potential applicant goes through a process } \\
\text { of disposal site selection by selecting a } \\
\text { region of interest, examining a number of } \\
\text { disposal sites within the area and } \\
\text { narrowing the choice to the proposed site. }\end{array}$ & $\begin{array}{l}\text { DOE Order } \\
5820.2 \mathrm{~A} \\
\text { Chapter III } \\
3 \mathrm{i}(7)(\mathrm{a}) \text { and }(\mathrm{b})\end{array}$ & $\begin{array}{l}\text { Disposal site selection criteria (based on } \\
\text { planned waste confinement technology) shall } \\
\text { be developed for establishing new LLW } \\
\text { disposal sites. Disposal site selection shall } \\
\text { be based on an evaluation of the prospective } \\
\text { site in conjunction with planned waste } \\
\text { confinement technology, and in accordance } \\
\text { with the NEPA process. }\end{array}$ & $\begin{array}{l}\text { Both statements acknowledge the need to } \\
\text { examine multiple choices for the site } \\
\text { selection. }\end{array}$ \\
\hline Siting & $\begin{array}{l}10 \text { CFR } \\
61.7(c)(1)\end{array}$ & $\begin{array}{l}\text { Through a detailed investigation of the } \\
\text { disposal site characteristics the potential } \\
\text { applicant obtains data on which to base an } \\
\text { analysis of the disposal site's suitability. }\end{array}$ & $\begin{array}{l}\text { DOE Order } \\
5820.2 \mathrm{~A} \\
\text { Chapter III } \\
3 \mathrm{i}(8)(\mathrm{a})\end{array}$ & $\begin{array}{l}\text { Design criteria shall be established prior to } \\
\text { selection of new disposal facilities, new } \\
\text { disposal sites, or both. These criteria shall } \\
\text { be based on analyses of physiographic, } \\
\text { environmental, and hydrogeologic data to } \\
\text { ensure that the policy and requirements of } \\
\text { this Order can be met. }\end{array}$ & $\begin{array}{l}\text { Both statements acknowledge the need for a } \\
\text { detailed evaluation of the site characteristics } \\
\text { to determine the site's suitability. }\end{array}$ \\
\hline Siting & $\begin{array}{l}10 \mathrm{CFR} \\
61.7(\mathrm{c})(1)\end{array}$ & $\begin{array}{l}\text { Through a detailed investigation of the } \\
\text { disposal site characteristics the potential } \\
\text { applicant obtains data on which to base an } \\
\text { analysis of the disposal site's suitability. }\end{array}$ & $\begin{array}{l}\text { DOE Order } \\
5820.2 \mathrm{~A} \\
\text { Chapter III } \\
3 \mathrm{i}(8)(\mathrm{a})\end{array}$ & $\begin{array}{l}\text { The criteria shall be also based on } \\
\text { assessments of projected waste volumes, } \\
\text { waste characteristics, and facility and } \\
\text { disposal site performance. }\end{array}$ & $\begin{array}{l}\text { Both statements acknowledge the need for a } \\
\text { detailed evaluation of the site characteristics } \\
\text { to determine the site's suitability. }\end{array}$ \\
\hline
\end{tabular}


Table B-1. (continued).

\begin{tabular}{|c|c|c|c|c|c|}
\hline Topic & NRC ref & Commercial requirement & DOE ref & DOE requirement & Discussion \\
\hline $\begin{array}{l}\text { License } \\
\text { Requirements }\end{array}$ & $\begin{array}{l}10 \mathrm{CFR} \\
61.7(\mathrm{c})(1)\end{array}$ & $\begin{array}{l}\text { Along with these data and analyses, the } \\
\text { applicant submits other more general } \\
\text { information to the Commission in the form } \\
\text { of an application for a license for land } \\
\text { disposal. }\end{array}$ & $\begin{array}{l}\text { Grumbly/ } \\
\text { O'Toole Interim } \\
\text { Policy Letter }\end{array}$ & $\begin{array}{l}\text { Headquarters elements review and approve } \\
\text { LLW disposal facilities PAs, and issue } \\
\text { disposal authorization statement that set forth } \\
\text { requirements important for assuring } \\
\text { compliance with LLW disposal facility } \\
\text { performance objectives. }\end{array}$ & $\begin{array}{l}\text { DOE reviews the site-specific performance } \\
\text { assessment to insure that the site will } \\
\text { perform suitably. }\end{array}$ \\
\hline \multirow[t]{2}{*}{ Operations } & $\begin{array}{l}10 \mathrm{CFR} \\
61.7(\mathrm{c})(2)\end{array}$ & $\begin{array}{l}\text { During the operational phase, the licensee } \\
\text { carries out disposal activities in accordance } \\
\text { with the requirements of this regulation and } \\
\text { any conditions on the license. }\end{array}$ & $\begin{array}{l}\text { Grumbly/ } \\
\text { O'Toole Interim } \\
\text { Policy Letter }\end{array}$ & $\begin{array}{l}\text { Field elements are required to implement the } \\
\text { interim policy and ensure that LLW } \\
\text { management activities are conducted in } \\
\text { accordance with this policy. }\end{array}$ & $\begin{array}{l}\text { The disposal authorization statement will set } \\
\text { forth requirements important to achieving } \\
\text { performance objectives. }\end{array}$ \\
\hline & & & $\begin{array}{l}\text { DOE Order } \\
5480.22,7 .\end{array}$ & $\begin{array}{l}\text { It is the policy of the Department that } \\
\text { facilities operate within PSO-approved } \\
\text { Technical Safety Requirements (TSRs) } \\
\text { which prescribe the bounds for safe } \\
\text { operations of these facilities in order to } \\
\text { protect the health and safety of the public } \\
\text { and reduce risk to workers. }\end{array}$ & $\begin{array}{l}\text { The DOE SAR process and the TSRs } \\
\text { process establish the safety envelope and } \\
\text { safety related requirements for operation of } \\
\text { the facility. This is an equivalent to a } \\
\text { license which also mandates essential } \\
\text { requirements. }\end{array}$ \\
\hline \multirow[t]{2}{*}{ Operations } & $\begin{array}{l}10 \text { CFR } \\
61.7(c)(2)\end{array}$ & $\begin{array}{l}\text { Periodically, the authority to conduct the } \\
\text { aboveground operations and dispose of the } \\
\text { waste will be subject to a license renewal, } \\
\text { at which time the operating history will be } \\
\text { reviewed and a decision made to permit or } \\
\text { deny operation. }\end{array}$ & $\begin{array}{l}\text { Grumblyl } \\
\text { O'Toole Interim } \\
\text { Policy Letter }\end{array}$ & $\begin{array}{l}\text { The Department can require shutdown of } \\
\text { disposal operations based on failure to } \\
\text { prepare an acceptable PA in a timely manner } \\
\text { or to maintain an adequate PA maintenance } \\
\text { program. }\end{array}$ & $\begin{array}{l}\text { DOE requires periodic maintenance of the } \\
\text { performance assessment. }\end{array}$ \\
\hline & - & & $\begin{array}{l}\text { DOE Orders } \\
5480.239 . c \text {, } \\
5480.229 . f\end{array}$ & $\begin{array}{l}\text { Contractors shall review and update SARs } \\
\text { annually as necessary, ...to ensure the } \\
\text { information is current and applicable. } \\
\text { Contractors shall determine if revisions to } \\
\text { the TSRs are necessary upon revision of the } \\
\text { SAR. }\end{array}$ & $\begin{array}{l}\text { The DOE has requirements to annually } \\
\text { review the SAR and associated TSRs. }\end{array}$ \\
\hline Closure & $\begin{array}{l}10 \mathrm{CFR} \\
61.7(\mathrm{c})(2)\end{array}$ & $\begin{array}{l}\text { When disposal operations are to cease, the } \\
\text { licensee applies for an amendment to his } \\
\text { license to permit site closure. }\end{array}$ & $\begin{array}{l}\text { DOE Order } \\
5820.2 \mathrm{~A} \text {, } \\
\text { Chapter III } 3 \mathrm{j}(5) \\
\end{array}$ & $\begin{array}{l}\text { Closure plans for new and existing operating } \\
\text { LLW disposal facilities shall be reviewed } \\
\text { and approved by the appropriate field } \\
\text { organization }\end{array}$ & $\begin{array}{l}\text { DOE facilities are closed according to } \\
\text { requirements of approved closure plans. } \\
\text { Closure activities will be performed under } \\
\text { the provisions of an approved closure plan in } \\
\text { accordance with DOE } 5820.2 \mathrm{~A} \text {. }\end{array}$ \\
\hline
\end{tabular}


Table B-1. (continued).

\begin{tabular}{|c|c|c|c|c|c|}
\hline Topic & NRC ref & Commercial requirement & DOE ref & DOE requirement & Discussion \\
\hline Closure & $\begin{array}{l}10 \text { CFR } \\
61.7(c)(2)\end{array}$ & $\begin{array}{l}\text { After review of the site closure and } \\
\text { stabilization plan, the Commission may } \\
\text { approve the final activities necessary to } \\
\text { prepare the disposal site so that ongoing } \\
\text { active maintenance of the site is not } \\
\text { required during the period of institutional } \\
\text { control. }\end{array}$ & $\begin{array}{l}\text { DOE Order } \\
5820.2 A \text {, } \\
\text { Chapter III } 3 \mathrm{j}(6)\end{array}$ & $\begin{array}{l}\text { Termination of monitoring and maintenance } \\
\text { activity at closed facilities or sites shall be } \\
\text { based on an analysis of site performance at } \\
\text { the end of the institutional control period. }\end{array}$ & $\begin{array}{l}\text { The Nuclear Regulatory Commission (NRC) } \\
\text { position seems to be that active maintenance } \\
\text { should not be necessary during the } \\
\text { institutional control period, and the DOE } \\
\text { position is that it will be continued, as } \\
\text { needed, until the end of the institutional } \\
\text { control period. }\end{array}$ \\
\hline Closure & $10 \mathrm{CFR}$ & Following the site closure phase, for a & DOE Order & The plan shall address closure of disposal & Unlike the NRC, which seeks to verify that \\
\hline
\end{tabular}

Closure $10 \mathrm{CFR} \quad$ Following the site closure phase, for a

61.7(c)(3)

period of $5 \mathrm{yr}$, the licensee must remain at the disposal site for a period of post-closure observation and maintenance to ensure that the disposal site is stable and ready for institutional control.

Closure $10 \mathrm{CFR}$ The Commission may approve shorter or $61.7(\mathrm{c})(3)$ require longer periods of closure observation and maintenance if conditions warrant.

Closure $\quad 10 \mathrm{CFR}$

$\infty$

$61.7(\mathrm{c})(3)$

Closure $\quad 10 \mathrm{CFR}$

61.7(c)(4)

Closure

10 CFR

61.7(c)(4)

License

10 CFR 61.10

Requirements

At the end of the observation and maintenance period, the licensee applies for a license transfer to the disposal site owner.

Under the conditions of the transferred license, the owner will carry out a program of monitoring to ensure continued satisfactory disposal site performance, physical surveillance to restrict access to the site, and carry out minor custodial activities.

At the end of the prescribed period of institutional control, the license will be terminated by the Commission.

An environmental report prepared in accordance with 10 CFR 51 Subpart A
5820.2A,

The plan shall address closure of disposal sites within a 5-yr period after each is filled

Chapter III $3 \mathrm{j}(1)$ and shall conform to the requirements of the NEPA process.

DOE Order

5820.2A,

Termination of monitoring and maintenance activity at closed facilities or sites shall be

Chapter III $3 \mathrm{j}(6)$ based on an analysis of site performance at [NEPA-Regulations Implementing Section 102(2)] must accompany the license application.
N/A

DOE Order

$5820.2 \mathrm{~A}$

Chapter III

DOE Order

5820.2A, activities at closed facilities or sites shall be

the end of the institutional control period.

10 CFR 1021.1 The purpose of 10 CFR 1021 is to establish procedures that the DOE shall use to comply with Section 102(2) of the NEPA of 1969 and the Council of Environmental Quality regulations for implementing procedural requirements of NEPA (40 CFR 1500-1508). treatment, storage, and disposal facil monitoring program that conforms with DOE 5484.1 and, at a minimum meets the réquirements of para. $3 \mathrm{k}(2)$ through (4) based on an analysis of site performance a the end of the institutional control period.

Unlike the NRC, which seeks to verify that the site is stable within $\mathbf{5} \mathrm{yr}$ after closure,

DOE maintains a program of maintenance and monitoring on the site for the entire institutional control period (100 yr).

Similar to the NRC statement, the DOE routinely bases termination of observation and maintenance activities based on technical criteria.

The DOE is both the operator and site owner so the DOE equivalent to license transfer is final closure under an opproved closure plan.

Both citations identify the need for an environmental monitoring plan.

The DOE has defined the point of termination of its activities for the disposal site, which is the equivalent of license termination.

The DOE and the NRC implement the requirements of Section 102(2) of the NEPA of 1969 differently. The DOE process requires holding public hearings and reviews and the NRC process makes the documentation available to the public but does not hold hearings. 
Table B-1. (continued).

\begin{tabular}{|c|c|c|c|c|c|}
\hline Topic & NRC ref & Commercial requirement & DOE ref & DOE requirement & Discussion \\
\hline Design & 10 CFR 61.13(a) & $\begin{array}{l}\text { Pathways analyzed in demonstrating } \\
\text { protection of the general population from } \\
\text { releases of radioactivity must include air, } \\
\text { soil, groundwater, surface water, plant } \\
\text { uptake, and exhumation by burrowing } \\
\text { animals. }\end{array}$ & $\begin{array}{l}\text { DOE Order } \\
5820.2 \mathrm{~A} \\
\text { Chapter III } \\
3 \mathrm{a}(2)\end{array}$ & $\begin{array}{l}\text { Ensure that external exposure to waste and } \\
\text { concentrations of radioactive material that } \\
\text { may be released into surface or } \\
\text { groundwater, soil, plants and animals results } \\
\text { in an effective dose equivalent (EDE) that } \\
\text { does not exceed } 25 \text { mrem/yr to any member } \\
\text { of public. }\end{array}$ & $\begin{array}{l}\text { Both citations are intended to identify the } \\
\text { need to analyze radionuclide transport } \\
\text { pathways. }\end{array}$ \\
\hline Design & 10 CFR 61.13(a) & $\begin{array}{l}\text { The analyses must clearly identify and } \\
\text { differentiate between the roles performed } \\
\text { by the natural disposal site characteristics } \\
\text { and design features in isolating and } \\
\text { segregating the wastes. }\end{array}$ & $\begin{array}{l}\text { DOE Order } \\
5820.2 A \\
\text { Chapter III } \\
3 f(2)\end{array}$ & $\begin{array}{l}\text { Waste treatment techniques such as } \\
\text { incineration, shredding, and compaction to } \\
\text { reduce volume and provide more stable } \\
\text { waste forms shall be implemented as } \\
\text { necessary to meet performance } \\
\text { requirements. }\end{array}$ & $\begin{array}{l}\text { Both requirements acknowledge the need to } \\
\text { consider both natural site confinement } \\
\text { characteristics and also engineered barriers. }\end{array}$ \\
\hline Design & 10 CFR 61.13(a) & $\begin{array}{l}\text { The analyses must clearly demonstrate that } \\
\text { there is reasonable assurance that the } \\
\text { exposure to humans from the release of } \\
\text { radioactivity will not exceed the limits set } \\
\text { forth in } 10 \text { CFR } 61.41 \text {. }\end{array}$ & $\begin{array}{l}\text { DOE Order } \\
5820.2 \mathrm{~A} \\
\text { Chapter III } \\
\text { 3a(2) }\end{array}$ & $\begin{array}{l}\text { Assure that external exposure to the wastes } \\
\text { and concentrations of radioactive material } \\
\text { which may be released into surface water, } \\
\text { ground water, soil, plants and animals result } \\
\text { in an effective dose equivalent that does not } \\
\text { exceed } 25 \text { mrem/yr to any member of the } \\
\text { public. Releases to the atmosphere shall } \\
\text { meet the requirements of } 40 \text { CFR } 61 . \\
\text { Reasonable effort should be made to } \\
\text { maintain releases of radioactivity in effluents } \\
\text { to the general environment at as low as } \\
\text { reasonably achievable (ALARA). }\end{array}$ & $\begin{array}{l}\text { Both NRC and DOE use } 25 \mathrm{mrem} / \mathrm{yr} \text { as the } \\
\text { all-pathways dose limit, but in different dose } \\
\text { systems. Thus, the actual level of protection } \\
\text { is different. }\end{array}$ \\
\hline Design & 10 CFR 61.13(b) & $\begin{array}{l}\text { Analyses of the protection of individuals } \\
\text { from inadvertent intrusion must include } \\
\text { demonstration that there is reasonable } \\
\text { assurance the waste classification and } \\
\text { segregation requirements will be met and } \\
\text { that adequate barriers to inadvertent } \\
\text { intrusion will be provided. }\end{array}$ & $\begin{array}{l}\text { DOE Order } \\
5820.2 \mathrm{~A} \\
\text { Chapter III } \\
3 \mathrm{a}(3)\end{array}$ & $\begin{array}{l}\text { LLW ... shall be managed to (3) Assure that } \\
\text { the committed EDEs received by individuals } \\
\text { who inadvertently may intrude into the } \\
\text { facility after the loss of active institutional } \\
\text { control shall not exceed } 100 \mathrm{mrem} / \mathrm{yr} \text { for } \\
\text { continuous exposure or } 500 \mathrm{mrem} \text { for a } \\
\text { single acute exposure }\end{array}$ & $\begin{array}{l}\text { Unlike the } 10 \text { CFR requirement, the DOE } \\
\text { establishes a maximum dose that can be } \\
\text { received by an inadvertent intruder. The } \\
\text { theoretical dose to the intruder is calculated } \\
\text { by site-specific PAs. }\end{array}$ \\
\hline Design & 10 CFR 61.13(c) & $\begin{array}{l}\text { Analyses of the protection of individuals } \\
\text { during operations must include assessments } \\
\text { of expected exposures due to routine } \\
\text { operations and likely accidents during } \\
\text { handling, storage, and disposal of waste. }\end{array}$ & $\begin{array}{l}\text { DOE Order } \\
5480.23 \\
\text { Paragraph } 6 .\end{array}$ & $\begin{array}{l}\text { It is the policy of the Dept. that nuclear } \\
\text { facilities and operations be analyzed to } \\
\text { identify all hazards and potential accidents } \\
\text { associated with the facility and ...to establish } \\
\text { designs and operational means to mitigate } \\
\text { these hazards and potential accidents. }\end{array}$ & $\begin{array}{l}\text { The DOE SAR process assesses all types of } \\
\text { hazards and accidents, including operator } \\
\text { radiation exposures. }\end{array}$ \\
\hline
\end{tabular}


Table B-1. (continued).

\begin{tabular}{|c|c|c|c|c|c|}
\hline Topic & NRC ref & Commercial requirement & DOE ref & DOE requirement & Discussion \\
\hline Design & 10 CFR 61.13(c) & $\begin{array}{l}\text { The analyses of doses to individuals during } \\
\text { operations must provide reasonable } \\
\text { assurance that exposures will be controlled } \\
\text { to meet the requirements of } \\
10 \mathrm{CFR} 20.1201 \text {. }\end{array}$ & $\begin{array}{l}10 \text { CFR } \\
835.202\end{array}$ & $\begin{array}{l}\text { The assessed dose from exposure of } \\
\text { occupational workers to radiation shall not } \\
\text { exceed the values summarized in Figure } 1 .\end{array}$ & $\begin{array}{l}\text { There are no differences in the permissible } \\
\text { doses between } 10 \text { CFR } 20 \text { and } 10 \text { CFR } 835 \text {. }\end{array}$ \\
\hline Design & 10 CFR 61.13(d) & $\begin{array}{l}\text { Analyses of the long-term stability of the } \\
\text { disposal site and the need for ongoing } \\
\text { active maintenance after closure must be } \\
\text { based upon analyses of active natural } \\
\text { processes such as erosion, mass wasting, } \\
\text { slope failure, settlement of wastes and } \\
\text { backfill... }\end{array}$ & $\begin{array}{l}\text { DOE Order } \\
5820.2 \mathrm{~A} \\
\text { Chapter III } 3 \mathrm{j}(6)\end{array}$ & $\begin{array}{l}\text { Termination of monitoring and maintenance } \\
\text { activity at closed facilities or sites shall be } \\
\text { based on an analysis of site performance at } \\
\text { the end of the institutional control period. }\end{array}$ & $\begin{array}{l}\text { Both requirements mandate analysis to } \\
\text { determine site stability performance and } \\
\text { associated maintenance requirements. The } \\
\text { DOE performance assessment will address } \\
\text { the long-term performance of the facility. }\end{array}$ \\
\hline Design & 10 CFR 61.13(d) & $\begin{array}{l}\text { The analyses must provide reasonable } \\
\text { assurance that there will not be a need for } \\
\text { ongoing active maintenance of the disposal } \\
\text { site following closure. }\end{array}$ & $\begin{array}{l}\text { DOE Order } \\
5820.2 \mathrm{~A}, \\
\text { Chapter III } 3 \mathrm{j}(6)\end{array}$ & $\begin{array}{l}\text { Termination of monitoring and maintenance } \\
\text { activity at closed facilities or sites shall be } \\
\text { based on an analysis of site performance at } \\
\text { the end of the institutional control period. }\end{array}$ & $\begin{array}{l}\text { The closure plan will address required } \\
\text { facility maintenance after closure. }\end{array}$ \\
\hline Design & 10 CFR 61.16 & $\begin{array}{l}\text { The Commission may also request } \\
\text { information on (a) physical security } \\
\text { measures, (b) safety information } \\
\text { concerning criticality. This information is } \\
\text { required for facilities receiving special } \\
\text { nuclear material in quantities subject to } \\
10 \text { CFR } 70.24 \text { and } 10 \text { CFR } 73 \text {. }\end{array}$ & $\begin{array}{l}\text { DOE Order } \\
6430.1 A \\
\text { Sections } \\
1300-10 \text { and } \\
1324-3\end{array}$ & $\begin{array}{l}\text { Section } 1300-10 \text { addresses design } \\
\text { requirements for physical protection, } \\
\text { material safeguards, and storage of special } \\
\text { nuclear materials. Section } 1324-3 \text { addresses } \\
\text { design requirements for criticality control. } \\
\end{array}$ & $\begin{array}{l}\text { The DOE } 6430.1 \mathrm{~A}, \text { "General Design } \\
\text { Criteria" establishes specific requirements } \\
\text { for these topics. They are also required } \\
\text { topics of the facility SAR governed by DOE } \\
\text { Order } 5480.23 \text {. }\end{array}$ \\
\hline \multirow[t]{2}{*}{$\begin{array}{l}\text { Licensing } \\
\text { Requirements }\end{array}$} & 10 CFR 61.23 & $\begin{array}{l}\text { A license for the receipt, possession, and } \\
\text { disposal of waste ... will be issued by the } \\
\text { Commission upon finding ... not be } \\
\text { inimical to the common defense and } \\
\text { security ... and health and safety of the } \\
\text { public, and that standards of } 10 \mathrm{CFR} 61.23 \\
\text { are met. }\end{array}$ & $\begin{array}{l}\text { Grumbly/ } \\
\text { O'Toole } \\
\text { Interim Policy } \\
\text { Letter }\end{array}$ & $\begin{array}{l}\text { Headquarters elements review and approve } \\
\text { LLW disposal facilities PAs, and issue } \\
\text { disposal authorization statements that set } \\
\text { forth requirements important for assuring } \\
\text { compliance with LLW disposal facility } \\
\text { performance objectives. }\end{array}$ & $\begin{array}{l}\text { DOE-HQ approval of the PA and issuance } \\
\text { of the disposal authorization statement } \\
\text { denotes that the disposal facility performance } \\
\text { is deemed acceptable. }\end{array}$ \\
\hline & & - & $\begin{array}{l}\text { DOE Order } \\
5480.31,1 .\end{array}$ & $\begin{array}{l}\text { This order, entitled "Startup and Restart of } \\
\text { Nuclear Facilities" has the stated purpose to } \\
\text { establish the actions to be taken and to } \\
\text { assign the responsibilities and authorities }\end{array}$ & $\begin{array}{l}\text { The review and approval authorities to allow } \\
\text { facility start-up activities are established by } \\
\text { DOE Order } 5480.31 \text {, based on potential } \\
\text { hazard category of the facility. }\end{array}$ \\
\hline
\end{tabular}


Table B-1. (continued).

\begin{tabular}{|c|c|c|c|c|c|}
\hline Topic & NRC ref & Commercial requirement & DOE ref & DOE requirement & Discussion \\
\hline Operations & 10 CFR $61.24(\mathrm{~g})$ & $\begin{array}{l}\text { No radioactive waste may be disposed of } \\
\text { until the Commission has inspected the land } \\
\text { disposal facility and has found it to be in } \\
\text { conformance with the description, design, } \\
\text { and construction described in the } \\
\text { application for a license. }\end{array}$ & $\begin{array}{l}\text { DOE Order } \\
5480.31 \\
9 . a(4)(a)\end{array}$ & $\begin{array}{l}\text { For initial startups of new hazard category } 1 \\
\text { and } 2 \text { nuclear facilities, the Sec. of Energy, } \\
\text { or designee, has startup authority. For initial } \\
\text { startup of new hazard category } 3 \text { nuclear } \\
\text { facilities, the Secretarial Officer, or } \\
\text { designee, has startup authority. }\end{array}$ & $\begin{array}{l}\text { Both the NRC and DOE have systems } \\
\text { established to ensure that all design and } \\
\text { operational aspects of the disposal facility } \\
\text { are in order before waste receipt operations } \\
\text { begin. }\end{array}$ \\
\hline Operations & 10 CFR 61.25 & $\begin{array}{l}\text { Except as provided for in specific license } \\
\text { conditions, the licensee shall not make } \\
\text { changes in the land disposal facility or } \\
\text { procedures described in the license } \\
\text { application. The license will include } \\
\text { conditions restricting subsequent changes to } \\
\text { the facility and the procedures authorized } \\
\text { which are important to public health and } \\
\text { safety. }\end{array}$ & $\begin{array}{l}\text { DOE Order } \\
5480.21 \text { Section } \\
10 . \mathrm{b}\end{array}$ & $\begin{array}{l}\text { A safety evaluation shall be performed when } \\
\text { any of the following are not described in the } \\
\text { existing safety analyses: (1) Temporary or } \\
\text { permanent changes in the facility, } \\
\text { (2) Temporary or permanent changes in the } \\
\text { procedures, (3) Tests or experiments. }\end{array}$ & $\begin{array}{l}\text { The DOE has defined an Unreviewed Safety } \\
\text { Question process and if it is found that the } \\
\text { above actions are not covered by the existing } \\
\text { safety analyses (which include the } \\
\text { performance assessment and SAR), the } \\
\text { action must be reviewed and approved at the } \\
\text { same approval level as the safety analyses. }\end{array}$ \\
\hline Operations & 10 CFR 61.25(a) & $\begin{array}{l}\text { These license restrictions will fall into } \\
\text { three categories of descending importance } \\
\text { to public health and safety as follows: } \\
\text { (1) those features and procedures which } \\
\text { may not be changed ... [review and } \\
\text { approval requirements of the } 3 \text { categories } \\
\text { given in text]. }\end{array}$ & $\begin{array}{l}\text { DOE Orders } \\
5480.21 \text { and } \\
5480.22\end{array}$ & $\begin{array}{l}\text { It is the policy of the Department that } \\
\text { facilities operate within PSO-approved TSRs } \\
\text { which prescribe the bounds for safe } \\
\text { operations of these facilities in order to } \\
\text { protect the health and safety of the public } \\
\text { and reduce risk to workers. }\end{array}$ & $\begin{array}{l}\text { The DOE Unreviewed Safety Question } \\
\text { (USQ) process (established in DOE Order } \\
5480.21 \text { ) does not establish categories for } \\
\text { approval, but operations may not proceed } \\
\text { until the USQ is resolved and the solution } \\
\text { approved at the same level of authority as } \\
\text { the applicable safety analyses. }\end{array}$ \\
\hline Operations & 10 CFR 61.26(a) & $\begin{array}{l}\text { An application for amendment of a license } \\
\text { must be filed in accordance with } \\
10 \text { CFR } 61.20 \text { and shall fully describe the } \\
\text { changes desired. }\end{array}$ & $\begin{array}{l}\text { DOE Order } \\
5480.21 \text { Section } \\
10 . b\end{array}$ & $\begin{array}{l}\text { A safety evaluation shall be performed when } \\
\text { any of the following are not described in the } \\
\text { existing safety analyses: (1) Temporary or } \\
\text { permanent changes in the facility, } \\
\text { (2) Temporary or permanent changes in the } \\
\text { procedures, (3) Tests or experiments. }\end{array}$ & $\begin{array}{l}\text { The DOE system requires contractors to go } \\
\text { through the formal Unreviewed Safety } \\
\text { Question process to make changes to the } \\
\text { safety envelope established by the SAR, PA, } \\
\text { and the TSRs. }\end{array}$ \\
\hline Closure & 10 CFR 61.28(a) & $\begin{array}{l}\text { Prior to final closure of the disposal site, or } \\
\text { as otherwise directed by the Commission, } \\
\text { the applicant shall submit an application to } \\
\text { amend the license for closure. }\end{array}$ & $\begin{array}{l}\text { DOE Order } \\
5820.2 \mathrm{~A} \text {, } \\
\text { Chapter III } 3 \mathrm{j}(5)\end{array}$ & $\begin{array}{l}\text { Closure plans for new and existing operating } \\
\text { LLW disposal facilities shall be reviewed } \\
\text { and approved by the appropriate field } \\
\text { organization. }\end{array}$ & $\begin{array}{l}\text { The DOE contractor is responsible to obtain } \\
\text { an approved closure plan for site closure. }\end{array}$ \\
\hline Closure & 10 CFR 61.28(a) & $\begin{array}{l}\text { This closure application must include a } \\
\text { final revision and specific details of the } \\
\text { disposal site closure plan included as part } \\
\text { of the license application submitted under } \\
10 \text { CFR } 61.12(\mathrm{~g} \text { ) that includes the } \\
\text { following: (1) Any additional geologic, ... }\end{array}$ & $\begin{array}{l}\text { DOE Order } \\
5820.2 \mathrm{~A}, \\
\text { Chapter III } 3 \mathrm{j}(5)\end{array}$ & $\begin{array}{l}\text { Closure plans for new and existing operating } \\
\text { LLW disposal facilities shall be reviewed } \\
\text { and approved by the appropriate field } \\
\text { organization. }\end{array}$ & $\begin{array}{l}\text { The DOE closure plan is the equivalent of } \\
\text { the closure information in the license } \\
\text { application. }\end{array}$ \\
\hline
\end{tabular}


Table B-1. (continued).

\begin{tabular}{|c|c|c|c|c|c|}
\hline Topic & NRC ref & Commercial requirement & DOE ref & DOE requirement & Discussion \\
\hline Closure & 10 CFR 61.28(b) & $\begin{array}{l}\text { An environmental report or a supplement } \\
\text { to an environmental report prepared in } \\
\text { accordance with subpart A of } 10 \mathrm{CFR} 51 \\
\text { must accompany the application. }\end{array}$ & $\begin{array}{l}10 \text { CFR } 1021.3 \\
14\end{array}$ & $\begin{array}{l}\text { DOE shall prepare a supplemental } \\
\text { Environmental Impact Statement (EIS) if } \\
\text { there are substantial changes to the proposal } \\
\text { or significant new circumstances or } \\
\text { information relevant to environmental } \\
\text { concerns, as discussed in }\end{array}$ & $\begin{array}{l}\text { DOE is required to supplement the EIS } \\
\text { governing its closure operation, if significant } \\
\text { new circumstances or information is known } \\
\text { at the time of the proposed closure } \\
\text { operation. }\end{array}$ \\
\hline
\end{tabular}

Closure 10 CFR 61.28(c) Upon review and consideration of an DOE Order SARs provide the bases for approval of new

Closure $\quad 10$ CFR $61.29 \quad$ Following completion of closure authorized

Closure $\quad 10$ CFR 61.29 Responsibility for the disposal site must be

Closure $\quad 10$ CFR $61.30 \quad$ Following closure and the period of application to amend the license for closure 5480.23 ,

submitted ..., the Commission shall issue an amendment authorizing closure if there is reasonable assurance that the long-term performance objectives will be met. in $10 \mathrm{CFR} 61.28$, the licensee shall observe, monitor, and carry out necessary maintenance and repairs at the disposal site until the license is transferred by the

Commission in accordance with 10 CFR 61.30. maintained by the licensee for $5 \mathrm{yr}$. A shorter or longer time period for post-closure observation and maintenance may be established and approved as part of the site closure plan based on site-specific conditions. post-closure observation and maintenance... The license shall be transferred when the Commission finds: (1) ..., (5) That the Fed. and State government agency which will assume responsibility for institutional control ...

Following any period of institutional control needed to meet the requirements found necessary under 61.23 , the licensee may apply for an amendment to terminate the license.
10 CFR 61.31(a)
Guidance

Section $3 a(1)$ facilities and operations, major modifications, and eventual decommissioning.

\section{DOE Order}

$5820.2 \mathrm{~A}$,

Termination of monitoring and maintenance activity at closed facilities or sites shall be

Chapter III $3 \mathrm{j}(6)$ based on an analysis of site performance at the end of the institutional control period.

DOE Order 5820.2A, Chapter III $3 \mathrm{j}(6)$ based on an analysis of site performance at the end of the institutional control period.

Since the closure activity is a major DOE operational activity, it will be covered by an approved SAR and the required closure plan. The approval of the SAR and final closure plan will be the DOE authorization for closure.

License transfer is not applicable for DOE facilities but the closure plan will ensure that post closure monitoring and maintenance is performed until it is technically justified to discontinue these functions.

License transfer is not applicable for DOE facilities but post closure monitoring and maintenance will be performed until it is technically justiffed to discontinue these functions.

Since the DOE is the owner for both the operational and the post-closure period, there is no equivalent to license transfer. 
Table B-1. (continued).

\begin{tabular}{|c|c|c|c|c|c|}
\hline Topic & NRC ref & Commercial requirement & DOE ref & DOE requirement & Discussion \\
\hline Closure & 10 CFR 61.31(b) & $\begin{array}{l}\text { A license is terminated when } \\
\text { (1) institutional control requirements have } \\
\text { been met, (2)...any additional requirements } \\
\text { resulting from new information developed } \\
\text { during the institutional control period have } \\
\text { been met and markers have been installed. }\end{array}$ & N/A & N/A & $\begin{array}{l}\text { Since the DOE is the owner for both } \\
\text { operation and the post-closure period there is } \\
\text { no equivalent to license termination. }\end{array}$ \\
\hline Design & 10 CFR 61.40 & $\begin{array}{l}\text { Land disposal facilities must be sited, } \\
\text { designed, operated, closed, and controlled } \\
\text { after closure so that reasonable assurance } \\
\text { exists that exposures to humans are within } \\
\text { the limits established in the performance } \\
\text { objectives in } 61.41 \text { through } 61.44 \text {. }\end{array}$ & $\begin{array}{l}\text { DOE Order } \\
5820.2 \mathrm{~A} \\
\text { Chapter III } \\
3 \mathrm{~b}(1)\end{array}$ & $\begin{array}{l}\text { Field organizations with disposal sites shall } \\
\text { prepare and maintain a site-specific } \\
\text { radiological performance assessment for the } \\
\text { disposal of waste for the purpose of } \\
\text { demonstrating compliance with the } \\
\text { performance objectives stated in para. 3a. }\end{array}$ & $\begin{array}{l}\text { Both citations require that radiation } \\
\text { exposures to the public meet similar criteria. }\end{array}$ \\
\hline Design & 10 CFR 61.41 & $\begin{array}{l}\text { Concentrations of radioactive material } \\
\text { which may be released to the general } \\
\text { environment in ground water, surface } \\
\text { water, air, soil, plants or animals must not } \\
\text { result in an annual dose exceeding an } \\
\text { equivalent of } 25 \text { mrem to the whole body, } \\
75 \text { mrem to the thyroid, ... }\end{array}$ & $\begin{array}{l}\text { DOE Order } \\
5820.2 \mathrm{~A} \\
\text { Chapter III } \\
3 \mathrm{a}(2)\end{array}$ & $\begin{array}{l}\text { Ensure that external exposure to waste and } \\
\text { concentrations of radioactive material which } \\
\text { may be released into surface or ground } \\
\text { water, soil, plants and animals results in an } \\
\text { EDE that does not exceed } 25 \mathrm{mrem} / \mathrm{yr} \text { to } \\
\text { any member of the public. }\end{array}$ & $\begin{array}{l}\text { The limit from in } 10 \text { CFR } 61.41 \text { is the same } \\
\text { as the DOE stated limit with the exception } \\
\text { that } 10 \text { CFR } 61.41 \text { allows } 75 \text { mrem to the } \\
\text { thyroid. The DOE limit is more } \\
\text { conservative. Thyroid exposure due to } \\
\text { iodine should not be significant for waste } \\
\text { emissions. }\end{array}$ \\
\hline Design & 10 CFR 61.41 & $\begin{array}{l}\text { Reasonable effort should be made to } \\
\text { maintain releases of radioactivity in } \\
\text { effluents to the general environment as low } \\
\text { as is reasonably achievable. }\end{array}$ & $\begin{array}{l}\text { DOE Order } \\
5820.2 \mathrm{~A} \\
\text { Chapter III } \\
3 \mathrm{a}(2)\end{array}$ & $\begin{array}{l}\text { Releases to the atmosphere shall meet the } \\
\text { requirements of } 40 \text { CFR } 61 \text {. Reasonable } \\
\text { effort should be made to maintain releases of } \\
\text { radioactivity in effluents to the general } \\
\text { environment ALARA. }\end{array}$ & $\begin{array}{l}\text { It is general DOE policy to always perform } \\
\text { the ALARA process in design and } \\
\text { operational activities. }\end{array}$ \\
\hline Design & 10 CFR 61.42 & $\begin{array}{l}\text { Design, operation, and closure of the land } \\
\text { disposal facility must ensure protection of } \\
\text { any individual inadvertently intruding into } \\
\text { the disposal site and occupying the site or } \\
\text { contracting the waste at any time after } \\
\text { active institutional controls are removed. }\end{array}$ & $\begin{array}{l}\text { DOE Order } \\
5820.2 \mathrm{~A} \\
\text { Chapter III } \\
3 \mathrm{a}(3)\end{array}$ & $\begin{array}{l}\text { DOE LLW ... shall be managed to } \\
\text { (3) ensure that the committed EDEs received } \\
\text { by individuals who inadvertently may intrude } \\
\text { into the facility after the loss of active } \\
\text { institutional control shall not exceed } \\
100 \mathrm{mrem} / \mathrm{yr} \text { for continuous exposure. }\end{array}$ & $\begin{array}{l}\text { The DOE performance assessment must } \\
\text { address the protection of the inadvertent } \\
\text { intruder and analyze how the performance } \\
\text { objective for this event will be met. }\end{array}$ \\
\hline Operations & 10 CFR 61.43 & $\begin{array}{l}\text { Operations at the land disposal facility must } \\
\text { be conducted in compliance with the } \\
\text { standards for radiation protection set out in } \\
\text { part } 20 \text { of this chapter, except for releases } \\
\text { in effluents from the land disposal facility } \\
\text { which shall be governed by } 61.41 \text {. }\end{array}$ & $\begin{array}{l}\text { DOE Order } \\
5480.11 \text { and } \\
10 \text { CFR } 835\end{array}$ & $\begin{array}{l}\text { DOE Order } 5480.11 \text { and the recently } \\
\text { codified } 10 \text { CFR } 835 \text { establish radiation } \\
\text { protection requirements for DOE } \\
\text { occupational workers. The equivalent for } \\
\text { the } 10 \text { CFR } 61.41 \text { requirement is found } \\
\text { under a discussion of that requirement. }\end{array}$ & $\begin{array}{l}\text { DOE has equivalent requirements to the } \\
\text { those of the NRC for worker protection and } \\
\text { effluent releases. }\end{array}$ \\
\hline Operations & 10 CFR $61.43^{\circ}$ & $\begin{array}{l}\text { Every reasonable effort shall be made to } \\
\text { maintain radiation exposures as low as is } \\
\text { reasonably achievable. }\end{array}$ & $\begin{array}{l}\text { DOE Orders } \\
5400.5 \text { Chapter } \\
\text { I.4 }\end{array}$ & $\begin{array}{l}\text { Accordingly, this Order adopts the ALARA } \\
\text { process in planning and carrying out all } \\
\text { DOE activities. }\end{array}$ & $\begin{array}{l}\text { It is general DOE policy to always perform } \\
\text { the ALARA process in design and } \\
\text { operational activities. }\end{array}$ \\
\hline
\end{tabular}


Table B-1. (continued).

\begin{tabular}{|c|c|c|c|c|c|}
\hline Topic & NRC ref & Commercial requirement & DOE ref & DOE requirement & Discussion \\
\hline Design & 10 CFR 61.44 & $\begin{array}{l}\text { The disposal facility must be sited, } \\
\text { designed, used, operated, and closed to } \\
\text { achieve long-term stability of the disposal } \\
\text { site and to eliminate to the extent } \\
\text { practicable the need for ongoing active } \\
\text { maintenance of the disposal site following } \\
\text { closure so that only surveillance, } \\
\text { monitoring, or minor custodial care are } \\
\text { required. }\end{array}$ & $\begin{array}{l}\text { DOE Order } \\
5820.2 \mathrm{~A} \text {, } \\
\text { Chapter III } 3 \mathrm{j}(6)\end{array}$ & $\begin{array}{l}\text { Termination of monitoring and maintenance } \\
\text { activity at closed facilities or sites shall be } \\
\text { based on an analysis of site performance at } \\
\text { the end of the institutional control period. }\end{array}$ & $\begin{array}{l}\text { The NRC places more emphasis on } \\
\text { minimizing the need for maintenance during } \\
\text { the institutional control period than the DOE } \\
\text { does. }\end{array}$ \\
\hline Siting & $\begin{array}{l}10 \mathrm{CFR} \\
61.50(\mathrm{a})(2)\end{array}$ & $\begin{array}{l}\text { The disposal site shall be capable of being } \\
\text { characterized, modeled, analyzed, and } \\
\text { monitored. }\end{array}$ & $\begin{array}{l}\text { DOE Order } \\
5820.2 \mathrm{~A} \\
\text { Chapter III } \\
3 \mathrm{i}(8)(\mathrm{b})\end{array}$ & $\begin{array}{l}\text { Disposal units shall be designed consistent } \\
\text { with disposal site hydrology, geology, and } \\
\text { waste characteristics and in accordance with } \\
\text { the NEPA process. }\end{array}$ & $\begin{array}{l}\text { Both requirements emphasize the need to } \\
\text { model and technically analyze the disposal } \\
\text { site. }\end{array}$ \\
\hline Siting & $\begin{array}{l}10 \mathrm{CFR} \\
61.50(a)(3)\end{array}$ & $\begin{array}{l}\text { Within the region or state where the facility } \\
\text { is located, a disposal site should be selected } \\
\text { so that projected population growth and } \\
\text { future developments are not likely to affect } \\
\text { the ability of the disposal facility to meet } \\
\text { the performance objectives. }\end{array}$ & $\begin{array}{l}\text { DOE Order } \\
5820.2 \mathrm{~A} \\
\text { Chapter III } \\
3 \mathrm{i}(7)(\mathrm{e})\end{array}$ & $\begin{array}{l}\text { Site selection criteria shall address the } \\
\text { impact on current and projected populations, } \\
\text { land use resource development plans and } \\
\text { nearby facilities, accessibility to } \\
\text { transportation routes and utilities, and the } \\
\text { location of waste generation. }\end{array}$ & Both citations have the same intent. \\
\hline Siting & $\begin{array}{l}10 \mathrm{CFR} \\
61.50(\mathrm{a})(4)\end{array}$ & $\begin{array}{l}\text { Areas must be avoided having known } \\
\text { natural resources which, if exploited, } \\
\text { would result in failure to meet the } \\
\text { performance objectives of subpart } C \text { of this } \\
\text { part. }\end{array}$ & $\begin{array}{l}\text { DOE Order } \\
5820.2 \mathrm{~A} \\
\text { Chapter III } \\
3 \mathrm{i}(7)(\mathrm{e})\end{array}$ & $\begin{array}{l}\text { Site selection criteria shall address the } \\
\text { impact on current and projected populations, } \\
\text { land use resource development plans and } \\
\text { nearby facilities, accessibility to } \\
\text { transportation routes and utilities, and the } \\
\text { location of waste generation. }\end{array}$ & $\begin{array}{l}\text { Both requirements require the consideration } \\
\text { of the site for future industrial use. }\end{array}$ \\
\hline Siting & $\begin{array}{l}10 \mathrm{CFR} \\
61.50(\mathrm{a})(5)\end{array}$ & $\begin{array}{l}\text { The disposal site must be generally well } \\
\text { drained an!l free of areas of flooding or } \\
\text { frequent ponding. Waste disposal shall not } \\
\text { take place in a } 100 \text {-yr flood plain, coastal } \\
\text { high-hazard area or wetland, as defined in } \\
\text { Executive Order } 11988 \text {. }\end{array}$ & $\begin{array}{l}\text { DOE Order } \\
6430.1 A \\
\text { Section } \\
0285-2.2 .2\end{array}$ & $\begin{array}{l}\text { The following environmentally sensitive } \\
\text { areas shall be avoided or receive lowest } \\
\text { siting priority for TSD of ...and radioactive } \\
\text { solid waste: (a) Wetlands, (b) Areas within } \\
\text { the } 500 \text {-yr floodplain, (c) Permafrost areas, } \\
\text { (d) critical habitats of endangered species, } \\
\text { (c) ... }\end{array}$ & $\begin{array}{l}\text { The DOE Order } 6430.1 \mathrm{~A}, \text { "General Design } \\
\text { Criteria," identifies environmental sensitive } \\
\text { areas like the NRC requirement. }\end{array}$ \\
\hline Siting & $\begin{array}{l}10 \mathrm{CFR} \\
61.50(\mathrm{a})(6)\end{array}$ & $\begin{array}{l}\text { Upstream drainage areas must be } \\
\text { minimized to decrease the amount of runoff } \\
\text { which could erode or inundate waste } \\
\text { disposal units. }\end{array}$ & $\begin{array}{l}\text { DOE Order } \\
6430.1 A \\
\text { Section } \\
0285-2.1\end{array}$ & $\begin{array}{l}\text { The following conditions and requirements } \\
\text { shall be considered during the selection of } \\
\text { solid waste TSD sites: (a) Existing } \\
\text { groundwater and surface water conditions, } \\
\text { (b) Soils and geologic and topographic } \\
\text { features,... }\end{array}$ & $\begin{array}{l}\text { Both requirements recognize the need to } \\
\text { consider surface water conditions. }\end{array}$ \\
\hline
\end{tabular}


Table B-1. (continued).

\begin{tabular}{|c|c|c|c|c|c|}
\hline Topic & NRC ref & Commercial requirement & DOE ref & DOE requirement & Discussion \\
\hline Siting & $\begin{array}{l}10 \mathrm{CFR} \\
61.50(\mathrm{a})(7)\end{array}$ & $\begin{array}{l}\text { The disposal site must provide sufficient } \\
\text { depth to the water table that ground water } \\
\text { intrusion, perennial or otherwise, into the } \\
\text { waste will not occur. The Commission } \\
\text { will consider an exception to this } \\
\text { requirement ... if it can be conclusively } \\
\text { shown ... }\end{array}$ & $\begin{array}{l}\text { DOE Order } \\
\text { 6430.1A } \\
\text { Section } \\
0285-3.2 .3\end{array}$ & $\begin{array}{l}\text { The following shall be considered to } \\
\text { determine potential impacts on groundwater } \\
\text { resources: ... (b) Depth to groundwater and } \\
\ldots ., \text { (c) Potential interactions of the solid } \\
\text { waste system and its hydrogeology with } \\
\text { areal, groundwater, and surface water } \\
\text { resources ... }\end{array}$ & Both citations have the same intent. \\
\hline Siting & $\begin{array}{l}10 \mathrm{CFR} \\
61.50(\mathrm{a})(7)\end{array}$ & $\begin{array}{l}\text { In no case will waste disposal be permitted } \\
\text { in the zone of fluctuation of the water } \\
\text { table. }\end{array}$ & $\begin{array}{l}\text { DOE Order } \\
\text { 6430.1A } \\
\text { Section } \\
0285-3.2 .3\end{array}$ & $\begin{array}{l}\text { The following shall be considered to } \\
\text { determine potential impacts on groundwater } \\
\text { resources: ... (b) Depth to groundwater and } \\
\ldots ., \text { (c) Potential interactions of the solid } \\
\text { waste system and its hydrogeology with } \\
\text { areal, groundwater, and surface water } \\
\text { resources ... }\end{array}$ & Both citations have the same intent. \\
\hline Siting & $\begin{array}{l}10 \text { CFR } \\
61.50(a)(8)\end{array}$ & $\begin{array}{l}\text { The hydrogeologic unit used for disposal } \\
\text { shall not discharge ground water to the } \\
\text { surface within the disposal site. }\end{array}$ & $\begin{array}{l}\text { DOE Order } \\
\text { 6430.1A } \\
\text { Section } \\
0285-3.2 .3\end{array}$ & $\begin{array}{l}\text { The following shall be considered to } \\
\text { determine potential impacts on groundwater } \\
\text { resources: ... (b) Depth to groundwater and } \\
\ldots, \text { (c) Potential interactions of the solid } \\
\text { waste system and its hydrogeology with } \\
\text { areal, groundwater, and surface water } \\
\text { resources... }\end{array}$ & Both citations have the same intent. \\
\hline Siting & $\begin{array}{l}10 \text { CFR } \\
61.50 \text { (a)(9) }\end{array}$ & $\begin{array}{l}\text { Areas must be avoided where tectonic } \\
\text { processes such as faulting, folding, ... may } \\
\text { occur with such frequency and extent to } \\
\text { significantly affect the ability of the site to } \\
\text { meet the performance objectives or may } \\
\text { preclude defensible modeling and } \\
\text { prediction... }\end{array}$ & $\begin{array}{l}\text { DOE Order } \\
\text { 6430.1A } \\
\text { Section } \\
\text { 0285-2.2.3 }\end{array}$ & $\begin{array}{l}\text { When potential sites are screened for } \\
\text { location of new solid waste TSD facilities, } \\
\text { seismic zones and karst (limestone } \\
\text { formation) terrain shall be avoided unless } \\
\text { site-specific evaluations demonstrate } \\
\text { minimum potential for contamination of } \\
\text { surface water, ... }\end{array}$ & The intent of the citations is the same. \\
\hline Siting & $\begin{array}{l}10 \text { CFR } \\
61.50(a)(10)\end{array}$ & $\begin{array}{l}\text { Areas must be avoided where surface } \\
\text { geologic processes such as mass wasting, } \\
\text { erosion ... may occur with such frequency } \\
\text { and extent to significantly affect the ability } \\
\text { of the site to meet the performance } \\
\text { objectives or may preclude defensible } \\
\text { modeling and... }\end{array}$ & $\begin{array}{l}\text { DOE Order } \\
5820.2 \mathrm{~A} \\
\text { Chapter III } \\
3 \mathrm{i}(7)(\mathrm{d})\end{array}$ & $\begin{array}{l}\text { The potential for natural hazards such as } \\
\text { floods, erosion, tornadoes, earthquakes, and } \\
\text { volcanoes shall be considered in site } \\
\text { selection. }\end{array}$ & The citations have the same intent. \\
\hline
\end{tabular}


Table B-1. (continued).

\begin{tabular}{|c|c|c|c|c|c|}
\hline Topic & NRC ref & Commercial requirement & DOE ref & DOE requirement & Discussion \\
\hline Siting & $\begin{array}{l}10 \text { CFR } \\
61.50 \text { (a)(11) }\end{array}$ & $\begin{array}{l}\text { The disposal site must not be located where } \\
\text { nearby facilities or activities could } \\
\text { adversely impact the ability of the site to } \\
\text { meet the performance objectives of subpart }\end{array}$ & $\begin{array}{l}\text { DOE Order } \\
\text { 6430.1A } \\
\text { Section } \\
0285-2.2 .8\end{array}$ & $\begin{array}{l}\text { Sites that would adversely affect operation of } \\
\text { other facilities should be avoided. }\end{array}$ & $\begin{array}{l}\text { Both criteria site the need to address } \\
\text { interactions between adjacent facilities in site } \\
\text { selection. }\end{array}$ \\
\hline
\end{tabular}

performance objectives of subpar

$\mathrm{C}$ of this part or significantly mask the

environmental monitoring program.

Design $\quad 10 \mathrm{CFR}$

toward long-term isolation and avoidance

DOE Order

Termination of monitoring and maintenance of the need for continuing active

$5820.2 \mathrm{~A}$, activity at closed facilities or sites shall be maintenance after site closure.

Chapter III $3 \mathrm{j}(6)$ based on an analysis of site performance at

the end of the institutional control period.

Design $\quad 10 \mathrm{CFR}$

The disposal site design and operation must DOE Order

be compatible with the disposal site closure $5820.2 \mathrm{~A}$

and stabilization plan and lead to disposal Chapter III site closure that provides reasonable

DOE LLW shall be managed on the

schedule developed in the Implementation

Plan to accomplish the performance

objectives stated in DOE Order 5820.2A,

assurance that the performance objectives

Chapter III, Section 3a.

$\begin{array}{lll} & \text { Design } & 10 \mathrm{CFR} \\ & & 61.51(\mathrm{a})(3) \\ \stackrel{1}{\sigma} & & \\ \stackrel{4}{\sigma} & & \end{array}$

$\stackrel{\leftrightarrow}{\stackrel{\leftrightarrow}{*}}$ of subpart $C$ of this part will be met.

The disposal site must be designed to complement and improve, where

DOE Order

$5820.2 \mathrm{~A}$,

appropriate, the ability of the disposal site's Chapter III natural characteristics to ensure that the $3 \mathrm{i}(8)(\mathrm{b})$

performance objectives of subpart $C$ of this part will be met.

$\begin{array}{ll}\text { Design } & 10 \mathrm{CFR} \\ & 61.51(\mathrm{a})(4)\end{array}$

$\begin{array}{ll}\text { Design } & 10 \mathrm{CFR} \\ & 61.51(\mathrm{a})(5)\end{array}$

Covers must be designed to minimize to the extent practicable water infiltration, to direct percolating or surface water away from the disposed waste, and to resist degradation by surface geologic processes and biotic activity.

Surface features must direct surface water drainage away from disposal units at velocities and gradients which will not result in erosion that will require ongoing active maintenance in the future.

DOE Order

$6430.1 \mathrm{~A}$

Section

1324-5.3

DOE Order

$6430.1 A$

Section

0285-2.1

Surface features must direct surface water DOE Order drainage away from disposal units at $5820.2 \mathrm{~A}$, velocities and gradients which will not Chapter III result in erosion that will require ongoing $3 \mathrm{i}(7)(\mathrm{c})$ active maintenance in the future.
Disposal units shall be designed consistent with disposal site hydrology, geology, and waste characteristics and in accordance with the NEPA process.

Means shall be provided to minimize contact of emplaced low-level waste with water. Active water control measures shall not be required following permanent closure.

Typical requirements for water control are:

(a) placing a layer of highly permeable ...

The following conditions and requirements shall be considered during the selection of solid waste TSD sites: (a) existing groundwater and surface water conditions, (b) soils and geologic and topographic features, ...

The disposal site shall have hydrogeologic characteristics which, in conjunction with the planned waste confinement technology, will protect the groundwater resource.
The NRC places more emphasis on minimizing the need for maintenance during the institutional control period than the DOE does.

Both statements establish the criteria that the facility design address long-term performance objectives.

Both statements have the same intent.

DOE Order 6430.1A, "General Design Criteria, " gives detailed design guidance for means of water control at a disposal facility.

Both citations address the control of ground water away from the disposal facility.

Both citations address the control of ground water away from the disposal facility. 
Table B-1. (continued).

\begin{tabular}{|c|c|c|c|c|c|}
\hline Topic & NRC ref & Commercial requirement & DOE ref & DOE requirement & Discussion \\
\hline Design & $\begin{array}{l}10 \mathrm{CFR} \\
61.51(\mathrm{a})(6)\end{array}$ & $\begin{array}{l}\text { The disposal site must be designed to } \\
\text { minimize to the extent practicable the } \\
\text { contact of water with waste during storage, } \\
\text { the contact of standing water with waste } \\
\text { during disposal, and the contact of } \\
\text { percolating or standing water with wastes } \\
\text { after disposal. }\end{array}$ & $\begin{array}{l}\text { DOE Order } \\
\text { 6430.1A } \\
\text { Section } \\
1324-5.3\end{array}$ & $\begin{array}{l}\text { Means shall be provided to minimize contact } \\
\text { of emplaced low-level waste with water. } \\
\text { Active water control measures shall not be } \\
\text { required following permanent closure. } \\
\text { Typical requirements for water control are: } \\
\text { (a) placing a layer of highly permeable ... }\end{array}$ & $\begin{array}{l}\text { DOE Order 6430.1A, "General Design } \\
\text { Criteria," gives detailed design guidance for } \\
\text { means of water control at a disposal facility. }\end{array}$ \\
\hline
\end{tabular}

$$
\text { after disposal. }
$$

Design $\quad 10 \mathrm{CFR}$

61.52(a)(1) other wastes by placing in disposal units which are sufficiently separated from

disposal units for other wastes classes so that interaction between Class $A$ wastes and other wastes will not result in failure to meet performance objectives in subpart $\mathbf{C}$. The segregation is not necessary for Class A wastes if they meet the stability

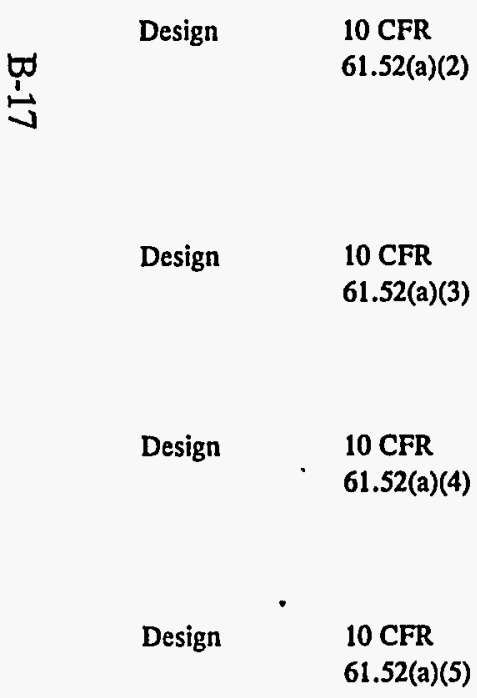

requirements in $61.56(\mathrm{~b})$ of this part.

the top of the waste is a minimum of $5 \mathrm{~m}$

below the top surface of the cover or mus be disposed of with intruder barriers that - are designed to protect against an inadvertent intrusion for at least $500 \mathrm{yr}$.

All wastes shall be disposed of in accordance with the requirements of paragraphs (a)(4) through (11) of this section.

Wastes must be emplaced in a manner that maintains the package integrity during emplacement, minimizes the void spaces between packages, and permits the void spaces to be filled.

Void spaces between waste packages must DOE Order be filled with earth or other material to $5820.2 \mathrm{~A}$, reduce future subsidence within the fill.

DOE Order

5820.2A,

DOE Order

$5820.2 \mathrm{~A}$,
DOE Order

5820.2A, appropriate to achieve the performance

Chapter III 3i(1) objectives stated in para. 3a, consistent with the disposal site radiological performance assessment in para. $3 \mathrm{~b}$.

LLW shall be disposed of by methods appropriate to achieve the performance

Chapter III 3i(1) objectives stated in para. 3a, consistent with the disposal site radiological performance assessment in para. $3 \mathrm{~b}$.

LLW shall be disposed of by methods appropriate to achieve the performance

Chapter III 3i(1) objectives stated in para. 3a, consistent with the disposal site radiological performance assessment in para. $3 \mathrm{~b}$.

DOE Order LLW shall be disposed of by methods 5820.2A, appropriate to achieve the performance

Chapter III $3 \mathrm{i}(1)$ objectives stated in para. 3a, consistent with the disposal site radiological performance assessment in para. $3 \mathrm{~b}$

Waste placement into disposal units should minimize voids between containers.
DOE does not have preset classification categories for waste as required by the NRC. Unlike the NRC, DOE determines allowable disposal practices for different types of waste on a case-by-case basis, as determined by the performance assessment. The NRC prescribes waste form and disposal requirements without considering site-specific details.

DOE determines allowable disposal practices for different types of waste on a

case-by-case basis, as determined by the performance assessment. DOE Order 5820.2A DOE Order 5820.2A, Chapter III.3a(3) states the allowable dose scenario.

DOE determines allowable disposal practices for different types of waste on a

case-by-case basis, as determined by the performance assessment.

DOE addresses package integrity requirements as part of the performance assessment. Issues such as initial strength and expected life of the package must be addressed in the analysis.

Both citations are concerned with minimizing voids between waste packages.
Chapter III

$3 i(9)(d)$ 
Table B-1. (continued).

\begin{tabular}{|c|c|c|c|c|c|}
\hline Topic & NRC ref & Commercial requirement & DOE ref & DOE requirement & Discussion \\
\hline Closure & $\begin{array}{l}10 \mathrm{CFR} \\
61.52(\mathrm{a})(6)\end{array}$ & $\begin{array}{l}\text { Waste must be placed and covered in a } \\
\text { manner that limits the radiation dose rate at } \\
\text { the surface of the cover to levels that at a } \\
\text { minimum will permit the licensee to } \\
\text { comply with provisions of } 10 \text { CFR } 20.1301 \\
\text { and } .1302 \text { at the time the license is } \\
\text { transferred. }\end{array}$ & $\begin{array}{l}\text { DOE Order } \\
5820.2 A \\
\text { Chapter III } 3 \mathrm{j}(2)\end{array}$ & $\begin{array}{l}\text { During closure and post closure, residual } \\
\text { radioactivity levels for surface soils shall } \\
\text { comply with existing DOE } \\
\text { decommissioning guidelines. }\end{array}$ & $\begin{array}{l}\text { Both citations are concerned with limiting } \\
\text { the potential radiation exposures at the } \\
\text { surface of the facility upon closure. }\end{array}$ \\
\hline Design & $\begin{array}{l}10 \mathrm{CFR} \\
61.52(\mathrm{a})(7)\end{array}$ & $\begin{array}{l}\text { The boundaries and locations of each } \\
\text { disposal unit must be accurately located } \\
\text { and mapped by means of a land survey. }\end{array}$ & $\begin{array}{l}\text { DOE Order } \\
5820.2 \mathrm{~A} \\
\text { Chapter III } \\
3 \mathrm{i}(9)(\mathrm{b})\end{array}$ & $\begin{array}{l}\text { Permanent identification markers for } \\
\text { disposal excavations and monitoring wells } \\
\text { shall be emplaced. }\end{array}$ & $\begin{array}{l}\text { Both citations address the need to relocate } \\
\text { the site boundaries. }\end{array}$ \\
\hline Design & $\begin{array}{l}10 \mathrm{CFR} \\
61.52(\mathrm{a})(7)\end{array}$ & $\begin{array}{l}\text { Near surface disposal units must be marked } \\
\text { in such a way that the boundaries of each } \\
\text { unit can be easily defined. }\end{array}$ & $\begin{array}{l}\text { DOE Order } \\
5820.2 \mathrm{~A} \\
\text { Chapter III } \\
3 \mathrm{i}(9)(\mathrm{b})\end{array}$ & $\begin{array}{l}\text { Permanent identification markers for } \\
\text { disposal excavations and monitoring wells } \\
\text { shall be emplaced. }\end{array}$ & $\begin{array}{l}\text { The citations both address marking the site } \\
\text { boundaries. }\end{array}$ \\
\hline Design & $\begin{array}{l}10 \mathrm{CFR} \\
61.52(\mathrm{a})(7)\end{array}$ & $\begin{array}{l}\text { Three permanent survey marker control } \\
\text { points, referenced to U.S. Geological } \\
\text { Survey (USGS) or National Geodetic } \\
\text { Survey (NGS) survey control stations, must } \\
\text { provide horizontal and vertical controls as } \\
\text { checked against USGS or NGS record } \\
\text { files. }\end{array}$ & $\begin{array}{l}\text { DOE Order } \\
5820.2 \mathrm{~A} \\
\text { Chapter III } \\
3 \mathrm{i}(9)(\mathrm{b})\end{array}$ & $\begin{array}{l}\text { Permanent identification markers for } \\
\text { disposal excavations and monitoring wells } \\
\text { shall be emplaced. }\end{array}$ & $\begin{array}{l}\text { The NRC requirement more specifically } \\
\text { addresses the marker requirements for the } \\
\text { site. This is a design detail which should } \\
\text { inherently be considered in erecting } \\
\text { permanent site markers. }\end{array}$ \\
\hline Design & $\begin{array}{l}10 \mathrm{CFR} \\
61.52(\mathrm{a})(8)\end{array}$ & $\begin{array}{l}\text { A buffer zone of land must be maintained } \\
\text { between any buried waste and the disposal } \\
\text { site boundary and beneath the disposed } \\
\text { waste. The buffer zone shall be of } \\
\text { adequate dimensions to carry out } \\
\text { environmental monitoring activities } \\
\text { specified in } 61.53 \text { (d)... }\end{array}$ & $\begin{array}{l}\text { DOE Order } \\
5820.2 \mathrm{~A} \\
\text { Chapter III } \\
3 \mathrm{k}(4)\end{array}$ & $\begin{array}{l}\text { The monitoring program shall be capable of } \\
\text { detecting changing trends in the performance } \\
\text { sufficiently in advance to allow application } \\
\text { of any necessary corrective action prior to } \\
\text { exceeding performance objectives. }\end{array}$ & $\begin{array}{l}\text { Although DOE does not specifically require } \\
\text { a buffer zone, it is normal in the design of a } \\
\text { monitoring plan which must detect trends in } \\
\text { time to prevent exceeding performance dose } \\
\text { objective to a surrounding public. }\end{array}$ \\
\hline Closure & $\begin{array}{l}10 \text { CFR } \\
61.52(\mathrm{a})(9)\end{array}$ & $\begin{array}{l}\text { Closure and stabilization measures as set } \\
\text { forth in the approved site closure plan must } \\
\text { be carried out as each disposal unit (e.g., } \\
\text { each (rench) is filled and covered. }\end{array}$ & $\begin{array}{l}\text { DOE Order } \\
5820.2 \mathrm{~A} \\
\text { Chapter III } \\
\text { 3i(9)(a) }\end{array}$ & $\begin{array}{l}\text { Field organizations shall develop and } \\
\text { implement operating procedures for LLW } \\
\text { disposal facilities that protect the } \\
\text { environment, health and safety of the public, } \\
\text { and facility personnel; ensure the security of } \\
\text { the facility; minimize the need for long-term } \\
\text { control; and meet ... }\end{array}$ & $\begin{array}{l}\text { The closure plan, which is completed prior } \\
\text { to first waste receipt, establishes the closure } \\
\text { and stabilization measures and schedule for } \\
\text { DOE sites. }\end{array}$ \\
\hline Design & $\begin{array}{l}10 \text { CFR } \\
61.52(\mathrm{a})(10)\end{array}$ & $\begin{array}{l}\text { Active waste disposal operations must not } \\
\text { have an adverse effect on completed } \\
\text { closure and stabilization measures. }\end{array}$ & $\begin{array}{l}\text { DOE Order } \\
5820.2 \mathrm{~A} \\
\text { Chapter III } \\
3 \mathrm{i}(9)(\mathrm{e})\end{array}$ & $\begin{array}{l}\text { Operations are to be conducted so that active } \\
\text { waste disposal operations will not have an } \\
\text { adverse effect on filled disposal units. }\end{array}$ & The intent of the two statements is the same. \\
\hline
\end{tabular}


Table B-1. (continued).

\begin{tabular}{|c|c|c|c|c|c|}
\hline Topic & NRC ref & Commercial requirement & DOE ref & DOE requirement & Discussion \\
\hline Waste Form & $\begin{array}{l}10 \text { CFR } \\
61.52(a)(11)\end{array}$ & $\begin{array}{l}\text { Only wastes containing or contaminated } \\
\text { with radioactive materials shall be disposed } \\
\text { of at the disposal site. }\end{array}$ & $\begin{array}{l}\text { DOE Order } \\
5820.2 \mathrm{~A} \\
\text { Chapter III 3i(6) }\end{array}$ & $\begin{array}{l}\text { Wastes containing amounts of radionuclides } \\
\text { below regulatory concern, as defined by } \\
\text { Federal regulations, may be disposed of } \\
\text { without regard to radioactivity content. }\end{array}$ & $\begin{array}{l}\text { The NRC and DOE requirements are } \\
\text { consistent with standard waste minimization } \\
\text { requirements to minimize waste volumes. }\end{array}$ \\
\hline Operations & 10 CFR 61.53(a) & $\begin{array}{l}\text { At the time a license application is } \\
\text { submitted, the applicant shall have } \\
\text { conducted a preoperational monitoring } \\
\text { program to provide basic environmental } \\
\text { data on the disposal site characteristics. }\end{array}$ & $\begin{array}{l}\text { DOE Order } \\
5400.1, \text { Ch. } \\
\text { IV.3 }\end{array}$ & $\begin{array}{l}\text { An environmental monitoring study shall be } \\
\text { conducted prior to start up of a new site, } \\
\text { facility, or process, which has the potential } \\
\text { for significant adverse environmental } \\
\text { impact. ... The study shall serve to: } \\
\text { characterize existing physical chemical, and } \\
\text {... }\end{array}$ & $\begin{array}{l}\text { The intent of these two requirements is the } \\
\text { same. }\end{array}$ \\
\hline Operations & 10 CFR 61.53(a) & $\begin{array}{l}\text { The applicant shall obtain information } \\
\text { about the ecology, meteorology, climate, } \\
\text { hydrology, geology, geochemistry, and } \\
\text { seismology of the disposal site. For those } \\
\text { characteristics that are subject to seasonal } \\
\text { variation, data must cover a } 12 \text {-month } \\
\text { period. }\end{array}$ & $\begin{array}{l}\text { DOE Order } \\
5400.1, \text { Ch. } \\
\text { IV.3 }\end{array}$ & $\begin{array}{l}\text { The preoperational study should begin not } \\
\text { less than } 1 \text { yr, and preferably } 2 \text { yr before } \\
\text { start up to evaluate seasonal changes. The } \\
\text { study shall serve to characterize existing } \\
\text { physical, chemical, and biological conditions } \\
\text { that could be affected; ... }\end{array}$ & $\begin{array}{l}\text { The intent of both of these requirements is to } \\
\text { identify site characteristics prior to } \\
\text { beginning operations to form a baseline. }\end{array}$ \\
\hline Operations & 10 CFR 61.53(b) & $\begin{array}{l}\text { The licensee must have plans for taking } \\
\text { corrective measures if migration of } \\
\text { radionuclides would indicate that the } \\
\text { performance objectives of subpart } C \text { may } \\
\text { not be met. }\end{array}$ & $\begin{array}{l}\text { DOE Order } \\
5820.2 \mathrm{~A}, \\
\text { Chapter III 3j(3) }\end{array}$ & $\begin{array}{l}\text { Corrective measures shall be applied to new } \\
\text { disposal sites or individual disposal units if } \\
\text { conditions occur or are forecasted that could } \\
\text { jeopardize attainment of the performance } \\
\text { objectives of this Order. }\end{array}$ & $\begin{array}{l}\text { Unlike the NRC, no written requirement was } \\
\text { found for a DOE corrective action plan in } \\
\text { the event that the monitoring plan shows } \\
\text { releases have occurred which will exceed } \\
\text { the performance objectives. }\end{array}$ \\
\hline Operations & 10 CFR 61.53(c) & $\begin{array}{l}\text { During the land disposal facility site } \\
\text { construction and operation, the licensee } \\
\text { shall maintain a monitoring program. }\end{array}$ & $\begin{array}{l}\text { DOE Order } \\
5400.1 \text { Chapter } \\
\text { IV }\end{array}$ & $\begin{array}{l}\text { This Order requires a site monitoring } \\
\text { program with a plan that identifies } \\
\text { monitoring requirements for the } \\
\text { pre-operational, operational, and } \\
\text { post-closure phases of the disposal facility } \\
\text { operation. }\end{array}$ & $\begin{array}{l}\text { The two citations both dictate monitoring } \\
\text { during the various phases of facility } \\
\text { operation. }\end{array}$ \\
\hline Operations & 10 CFR 61.53(c) & $\begin{array}{l}\text { Measurements and observations must be } \\
\text { made and recorded to provide data to } \\
\text { evaluate the potential health and } \\
\text { environmental impacts during both the } \\
\text { construction and the operation of the } \\
\text { facility and to enable the evaluation of } \\
\text { long-term effects and the need... }\end{array}$ & $\begin{array}{l}\text { DOE Order } \\
5820.2 A \\
\text { Chapter III } \\
3 m(1)\end{array}$ & $\begin{array}{l}\text { Each field organization shall develop and } \\
\text { maintain a record keeping system that } \\
\text { records: (a) historical record of waste } \\
\text { generated, treated, stored, shipped, disposed } \\
\text { of, or both, at the facilities under its } \\
\text { cognizance. The data maintained shall } \\
\text { include all data necessary to show that the } \\
\text { waste was properly classified, treated, } \\
\text { stored, shipped, and/or disposed of. }\end{array}$ & $\begin{array}{l}\text { Although the DOE citation does not } \\
\text { specifically include monitoring during the } \\
\text { construction phase of the operation, it seems } \\
\text { to be included in the facility monitoring } \\
\text { program. }\end{array}$ \\
\hline
\end{tabular}


Table B-1. (continued).

\begin{tabular}{|c|c|c|c|c|c|}
\hline Topic & NRC ref & Commercial requirement & DOE ref & DOE requirement & Discussion \\
\hline Design & 10 CFR 61.53(c) & $\begin{array}{l}\text { The monitoring system (used during site } \\
\text { construction and operation) must be } \\
\text { capable of providing early warning of } \\
\text { releases of radionuclides from the disposal } \\
\text { site before they leave the site boundary. }\end{array}$ & $\begin{array}{l}\text { DOE Order } \\
5820.2 \mathrm{~A}, \\
\text { Chapter III } \\
3 \mathrm{k}(4)\end{array}$ & $\begin{array}{l}\text { The monitoring program shall be capable of } \\
\text { detecting changing trends in the performance } \\
\text { sufficiently in advance to allow application } \\
\text { of any necessary corrective action prior to } \\
\text { exceeding performance objectives. }\end{array}$ & These citations have the same intent. \\
\hline Operations & 10 CFR 61.53(d) & $\begin{array}{l}\text { After the disposal site is closed, the } \\
\text { licensee responsible for post-operational } \\
\text { surveillance of the disposal site shall } \\
\text { maintain a monitoring system based on the } \\
\text { operating history and the closure and } \\
\text { stabilization of the disposal site. }\end{array}$ & $\begin{array}{l}\text { DOE Order } \\
5400.1 \text { Chapter } \\
\text { IV }\end{array}$ & $\begin{array}{l}\text { This Order requires a site monitoring } \\
\text { program with a plan that identifies } \\
\text { monitoring requirements for the } \\
\text { pre-operational, operational, and } \\
\text { post-closure phases of the disposal facility } \\
\text { operation. }\end{array}$ & The intent of these citations is the same. \\
\hline Design & 10 CFR 61.53(d) & $\begin{array}{l}\text { The monitoring system (used for post } \\
\text { operational surveillance) must be capable } \\
\text { of providing early warning of releases of } \\
\text { radionuclides from the disposal site before } \\
\text { they leave the site boundary. }\end{array}$ & $\begin{array}{l}\text { DOE Order } \\
5820.2 \mathrm{~A}, \\
\text { Chapter III } \\
3 \mathrm{k}(4)\end{array}$ & $\begin{array}{l}\text { The monitoring program shall be capable of } \\
\text { detecting changing trends in the performance } \\
\text { sufficiently in advance to allow application } \\
\text { of any necessary corrective action prior to } \\
\text { exceeding performance objectives. }\end{array}$ & The intent of the two statements is the same. \\
\hline Design & 10 CFR 61.54 & $\begin{array}{l}\text { The Commission may, upon request or on } \\
\text { its own initiative, authorize provisions } \\
\text { other than those set forth in } 61.51 \text { through } \\
61.53 \text { for the segregation and disposal of } \\
\text { waste and for the design and operation of a } \\
\text { land disposal facility on a specific basis, } \\
\text { if... }\end{array}$ & $\begin{array}{l}\text { DOE Order } \\
5820.2 \mathrm{~A}, \\
\text { Chapter III 3i(1) }\end{array}$ & $\begin{array}{l}\text { LLW shall be disposed of by methods } \\
\text { appropriate to achieve the performance } \\
\text { objectives stated in para. } 3 \mathrm{a} \text {, consistent with } \\
\text { the disposal site radiological performance } \\
\text { assessment in para. } 3 \mathrm{~b} \text {. }\end{array}$ & $\begin{array}{l}\text { This and statements like it, which allow } \\
\text { exceptions to the rules, make the } \\
\text { requirements of } 10 \mathrm{CFR} 61 \text { changeable with } \\
\text { technical justification. DOE relies on the } \\
\text { performance assessment to establish } \\
\text { requirements based on technical justification. }\end{array}$ \\
\hline Waste Form & $\begin{array}{l}10 \mathrm{CFR} \\
61.55(\mathrm{a})(1)\end{array}$ & $\begin{array}{l}\text { First, consideration must be given to the } \\
\text { concentration of long-lived radionuclides } \\
\text { whose potential hazard will persist long } \\
\text { after such precautions as institutional } \\
\text { controls, improved waste form, and deeper } \\
\text { disposal have ceased to be effective. }\end{array}$ & $\begin{array}{l}\text { DOE Order } \\
5820.2 \mathrm{~A}, \\
\text { Chapter III 3i(2) }\end{array}$ & $\begin{array}{l}\text { In the course of this process, site-specific } \\
\text { waste classification limits may be developed } \\
\text { if operationally useful in determining how } \\
\text { specific wastes should be stabilized and } \\
\text { packaged for disposal. }\end{array}$ & $\begin{array}{l}\text { DOE has chosen to rely on the performance } \\
\text { assessment results to determine the waste } \\
\text { acceptance criteria of the disposal facility, } \\
\text { rather than having predetermined low-level } \\
\text { waste classifications. }\end{array}$ \\
\hline Waste Form & $\begin{array}{l}10 \text { CFR } \\
61.55(a)(2)(i)\end{array}$ & $\begin{array}{l}\text { Class } A \text { waste is waste that is usually } \\
\text { segregated from other waste classes at the } \\
\text { disposal site. The physical form and } \\
\text { characteristics of Class } A \text { waste must meet } \\
\text { the minimum requirements set forth in }\end{array}$ & $\begin{array}{l}\text { DOE Order } \\
5820.2 \mathrm{~A}, \\
\text { Chapter Ill } 3 \mathrm{i}(2)\end{array}$ & $\begin{array}{l}\text { In the course of this process, site-specific } \\
\text { waste classification limits may be developed } \\
\text { if operationally useful in determining how } \\
\text { specific wastes should be stabilized and } \\
\text { packaged for disposal. }\end{array}$ & $\begin{array}{l}\text { DOE has chosen to rely on the performance } \\
\text { assessment results as a basis to determine } \\
\text { the waste acceptance criteria of the disposal } \\
\text { facility, rather than having predetermined } \\
\text { low-level waste classifications. }\end{array}$ \\
\hline
\end{tabular}


Table B-1. (continued).

\begin{tabular}{|c|c|c|c|c|c|}
\hline Topic & NRC ref & Commercial requirement & DOE ref & DOE requirement & Discussion \\
\hline Waste Form & $\begin{array}{l}10 \mathrm{CFR} \\
61.55(\mathrm{a})(2)(\mathrm{i})\end{array}$ & $\begin{array}{l}\text { If Class } A \text { waste also meets the stability } \\
\text { requirements set forth in } 61.56(\mathrm{~b}) \text {, it is not } \\
\text { necessary to segregate the waste for } \\
\text { disposal. }\end{array}$ & $\begin{array}{l}\text { DOE Order } \\
5820.2 \mathrm{~A}, \\
\text { Chapter III 3i(2) }\end{array}$ & $\begin{array}{l}\text { In the course of this process, site-specific } \\
\text { waste classification limits may be developed } \\
\text { if operationally useful in determining how } \\
\text { specific wastes should be stabilized and } \\
\text { packaged for disposal. }\end{array}$ & $\begin{array}{l}\text { DOE has chosen to rely on the performance } \\
\text { assessment results as a basis to determine } \\
\text { the waste acceptance criteria of the disposal } \\
\text { facility, rather than having predetermined } \\
\text { low-level waste classifications and disposal } \\
\text { criteria. }\end{array}$ \\
\hline Waste Form & $\begin{array}{l}10 \text { CFR } \\
61.55(a)(2)(i i)\end{array}$ & $\begin{array}{l}\text { Class B waste is waste that must meet } \\
\text { more rigorous requirements on waste form } \\
\text { to ensure stability after disposal. The } \\
\text { physical form and characteristics of } \\
\text { Class B waste must meet both the } \\
\text { minimum and stability requirements set } \\
\text { forth in } 61.56 \text {. }\end{array}$ & $\begin{array}{l}\text { DOE Order } \\
5820.2 \mathrm{~A} \text {, } \\
\text { Chapter III 3i(2) }\end{array}$ & $\begin{array}{l}\text { In the course of this process, site-specific } \\
\text { waste classification limits may be developed } \\
\text { if operationally useful in determining how } \\
\text { specific wastes should be stabilized and } \\
\text { packaged for disposal. }\end{array}$ & $\begin{array}{l}\text { DOE has chosen to rely on the performance } \\
\text { assessment results as a basis to determine } \\
\text { the waste acceptance criteria of the disposal } \\
\text { facility, rather than having predetermined } \\
\text { low-level waste classifications. }\end{array}$ \\
\hline Waste Form & $\begin{array}{l}10 \text { CFR } \\
61.55(a)(2)(\mathrm{iii})\end{array}$ & $\begin{array}{l}\text { Class } \mathrm{C} \text { waste is waste that not only must } \\
\text { meet more rigorous requirements on waste } \\
\text { form to ensure stability but also requires } \\
\text { additional measures at the disposal facility } \\
\text { to protect against inadvertent intrusion. }\end{array}$ & $\begin{array}{l}\text { DOE Order } \\
5820.2 \mathrm{~A}, \\
\text { Chapter III 3i(2) }\end{array}$ & $\begin{array}{l}\text { In the course of this process, site-specific } \\
\text { waste classification limits may be developed } \\
\text { if operationally useful in determining how } \\
\text { specific wastes should be stabilized and } \\
\text { packaged for disposal. }\end{array}$ & $\begin{array}{l}\text { DOE has chosen to rely on the performance } \\
\text { assessment results as a basis to determine } \\
\text { the waste acceptance criteria of the disposal } \\
\text { facility, rather than having predetermined } \\
\text { low-level waste classifications, waste form, } \\
\text { and disposal criteria. }\end{array}$ \\
\hline Waste Form & $\begin{array}{l}10 \text { CFR } \\
61.55(a)(2)(\mathrm{iii})\end{array}$ & $\begin{array}{l}\text { The physical form and characteristics of } \\
\text { Class } \mathrm{C} \text { waste must meet both the } \\
\text { minimum and stability requirements set } \\
\text { forth in } 61.56 \text {. }\end{array}$ & $\begin{array}{l}\text { DOE Order } \\
5820.2 \mathrm{~A}, \\
\text { Chapter III 3i(2) }\end{array}$ & $\begin{array}{l}\text { In the course of this process, site-specific } \\
\text { waste classification limits may be developed } \\
\text { if operationally useful in determining how } \\
\text { specific wastes should be stabilized and } \\
\text { packaged for disposal. }\end{array}$ & $\begin{array}{l}\text { DOE has chosen to rely on the performance } \\
\text { assessment results as a basis to determine } \\
\text { the waste acceptance criteria of the disposal } \\
\text { facility, rather than having predetermined } \\
\text { low-level waste classifications and waste } \\
\text { form criteria. }\end{array}$ \\
\hline Waste Form & $\begin{array}{l}10 \text { CFR } \\
61.55(a)(2)(i v)\end{array}$ & $\begin{array}{l}\text { Waste that is not generally acceptable for } \\
\text { near-surface disposal is waste for which } \\
\text { form and disposal methods must be } \\
\text { different, and in general more stringent, } \\
\text { than those specified for Class } C \text { waste. }\end{array}$ & $\begin{array}{l}\text { DOE Order } \\
5820.2 \mathrm{~A}, \\
\text { Chapter III 3i(4) }\end{array}$ & $\begin{array}{l}\text { Disposition of waste designated as GTCC, as } \\
\text { defined in } 10 \text { CFR } 61.55 \text {, must be handled } \\
\text { as special cases. }\end{array}$ & $\begin{array}{l}\text { DOE has chosen to rely on the performance } \\
\text { assessment results as a basis to determine } \\
\text { the waste acceptance criteria of the disposal } \\
\text { facility, rather than having predetermined } \\
\text { low-level waste classifications and disposal } \\
\text { criteria. }\end{array}$ \\
\hline Waste Form & $\begin{array}{l}10 \text { CFR } \\
61.55(a)(2)(i v)\end{array}$ & $\begin{array}{l}\text { In the absence of specific requirements in } \\
\text { this part, such waste must be disposed of in } \\
\text { a geologic repository as defined in part } 60 \\
\text { of this chapter unless proposals for disposal } \\
\text { of such waste in a disposal site licensed } \\
\text { pursuant to this part are approved }\end{array}$ & $\begin{array}{l}\text { DOE Order } \\
5820.2 \mathrm{~A} \text {, } \\
\text { Chapter III 3i(4) }\end{array}$ & $\begin{array}{l}\text { Disposition of waste designated as GTCC, as } \\
\text { defined in } 10 \text { CFR } 61.55 \text {, must be handled } \\
\text { as special cases. }\end{array}$ & $\begin{array}{l}\text { DOE has chosen to rely on the performance } \\
\text { assessment results as a basis to determine } \\
\text { the waste acceptance criteria of the disposal } \\
\text { facility, rather than having predetermined } \\
\text { low-level waste classifications and disposal } \\
\text { criteria. }\end{array}$ \\
\hline
\end{tabular}


Table B-1. (continued).

\begin{tabular}{|c|c|c|c|c|c|}
\hline Topic & NRC ref & Commercial requirement & DOE ref & DOE requirement & Discussion \\
\hline Waste Form & $\begin{array}{l}10 \mathrm{CFR} \\
61.55(\mathrm{a})(8)\end{array}$ & $\begin{array}{l}\text { The concentration of a radionuclide may be } \\
\text { determined by indirect methods such as use } \\
\text { of scaling factors which relate inferred } \\
\text { concentration of one radionuclide to } \\
\text { another that is measured, or indirect } \\
\text { methods can be correlated with actual } \\
\text { measurements. The concentration of a } \\
\text { radionuclide may be averaged over the } \\
\text { volume of the waste, or weight of the } \\
\text { waste if the units are expressed in } \mathrm{nCi} / \mathrm{g} \text {. }\end{array}$ & $\begin{array}{l}\text { DOE Order } \\
5820.2 \mathrm{~A}, \\
\text { Chapter III } \\
3 \mathrm{~d}(3)\end{array}$ & $\begin{array}{l}\text { The concentration may be determined by } \\
\text { direct methods or by indirect methods such } \\
\text { as using of scaling factors which relate the } \\
\text { inferred concentration of one radionuclide to } \\
\text { another that is measured, or radionuclide } \\
\text { material accountability, if there is ... }\end{array}$ & $\begin{array}{l}\text { Both requirements allow the use of indirect } \\
\text { methods stuch as the use of scaling factors. } \\
\text { DOE } 5820.2 \mathrm{~A} \text { does not include a statement } \\
\text { on concentration averaging but guidance on } \\
\text { concentration averaging is provided in } \\
\text { DOE/LLW-75T. }\end{array}$ \\
\hline Waste Form & $\begin{array}{l}10 \mathrm{CFR} \\
61.56(\mathrm{a})(1)\end{array}$ & $\begin{array}{l}\text { Waste must not be packaged for disposal in } \\
\text { cardboard or fiberboard boxes. }\end{array}$ & $\begin{array}{l}\text { DOE Order } \\
5820.2 \mathrm{~A} \\
\text { Chapter III } \\
3 \mathrm{i}(5)(\mathrm{a})\end{array}$ & $\begin{array}{l}\text { (a) Waste must not be packaged for disposal } \\
\text { in cardboard or fiberboard boxes, unless } \\
\text { such boxes meet DOT requirements and } \\
\text { contain stabilized waste with a minimum of } \\
\text { void space. }\end{array}$ & $\begin{array}{l}\text { DOE has chosen to specify waste container } \\
\text { requirements in the waste acceptance criteria } \\
\text { based on technical considerations of the } \\
\text { wasteform, handling processes, and disposal } \\
\text { considerations. }\end{array}$ \\
\hline Waste Form & $\begin{array}{l}10 \mathrm{CFR} \\
61.56(\mathrm{a})(2)\end{array}$ & $\begin{array}{l}\text { Liquid waste must be solidified or } \\
\text { packaged in sufficient absorbent material to } \\
\text { absorb twice the volume of liquid. }\end{array}$ & $\begin{array}{l}\text { DOE Order } \\
5820.2 \mathrm{~A} \\
\text { Chapter III } \\
3 \mathrm{i}(5)(\mathrm{b})\end{array}$ & $\begin{array}{l}\text { (b) Liquid wastes, or wastes containing free } \\
\text { liquid, must be converted into a form that } \\
\text { contains as little freestanding and } \\
\text { noncorrosive liquid as reasonably } \\
\text { achievable, but in no case, shall the liquid } \\
\text { exceed } 1 \% \text { of the volume of the waste when } \\
\text {... }\end{array}$ & $\begin{array}{l}\text { Both citations are concerned with solidifying } \\
\text { free liquid. The NRC is more prescriptive. }\end{array}$ \\
\hline Waste Form & $\begin{array}{l}10 \mathrm{CFR} \\
61.56(\mathrm{a})(3)\end{array}$ & $\begin{array}{l}\text { Solid waste containing liquid shall contain } \\
\text { as little free standing and noncorrosive } \\
\text { liquid as is reasonably achievable, but in no } \\
\text { case shall the liquid exceed } 1 \% \text { of the } \\
\text { volume. }\end{array}$ & $\begin{array}{l}\text { DOE Order } \\
5820.2 \mathrm{~A} \\
\text { Chapter III } \\
3 \mathrm{i}(5)(\mathrm{b})\end{array}$ & $\begin{array}{l}\text { (b) Liquid wastes, or wastes containing free } \\
\text { liquid, must be converted into a form that } \\
\text { contains as little freestanding and } \\
\text { noncorrosive liquid as reasonably } \\
\text { achievable, but in no case, shall the liquid } \\
\text { exceed } 1 \% \text { of the volume of the waste when } \\
\text {... }\end{array}$ & $\begin{array}{l}\text { The DOE requirement also addresses free } \\
\text { liquid requirements for a stabilized } \\
\text { wasteform. }\end{array}$ \\
\hline Waste Form & $\begin{array}{l}10 \mathrm{CFR} \\
61.56(\mathrm{a})(4)\end{array}$ & $\begin{array}{l}\text { Waste must not be readily capable of } \\
\text { detonation or of explosive decomposition } \\
\text { or reaction at normal pressures and } \\
\text { temperatures, or of explosive reaction with } \\
\text { water. }\end{array}$ & $\begin{array}{l}\text { DOE Order } \\
5820.2 A \\
\text { Chapter III } \\
3 \mathrm{i}(5)(c)\end{array}$ & $\begin{array}{l}\text { (c) Waste must not be readily capable of } \\
\text { detonation or of explosive decomposition or } \\
\text { reaction at normal pressures and } \\
\text { temperatures or of explosive reaction with } \\
\text { water. }\end{array}$ & The requirements are the same. \\
\hline Waste Form & $\begin{array}{l}10 \mathrm{CFR} \\
61.56(\mathrm{a})(5)\end{array}$ & $\begin{array}{l}\text { Waste must not contain, or be capable of } \\
\text { generating, quantities of toxic gases, } \\
\text { vapors, or fumes harmful to persons } \\
\text { transporting, handling, or disposing of the } \\
\text { waste. This does not apply to radioactive } \\
\text { gases packaged in accordance with }(a)(7) .\end{array}$ & $\begin{array}{l}\text { DOE Order } \\
5820.2 \mathrm{~A}, \\
\text { Chapter III } \\
3 \mathrm{i}(5)(\mathrm{d})\end{array}$ & $\begin{array}{l}\text { (d) Waste must not contain, or be capable of } \\
\text { generating, quantities of toxic gases, vapors, } \\
\text { or fumes harmful to persons transporting, } \\
\text { handling, or disposing of the waste. This } \\
\text { does not apply to radioactive gaseous waste } \\
\text { packaged as identified in para. 3i(5)(e). }\end{array}$ & The requirements are the same. \\
\hline
\end{tabular}


Table B-1. (continued).

\begin{tabular}{|c|c|c|c|c|c|}
\hline Topic & NRC ref & Commercial requirement & DOE ref & DOE requirement & Discussion \\
\hline Waste Form & $\begin{array}{l}10 \text { CFR } \\
61.56(a)(6)\end{array}$ & $\begin{array}{l}\text { Waste must not be pyrophoric. Pyrophoric } \\
\text { materials contained in waste shall be } \\
\text { treated, prepared, and packaged to be } \\
\text { nonflammable. }\end{array}$ & $\begin{array}{l}\text { DOE Order } \\
5820.2 \mathrm{~A} \\
\text { Chapter III } \\
3 \mathrm{i}(5)(\mathrm{f})\end{array}$ & $\begin{array}{l}\text { (f) Waste must not be pyrophoric. } \\
\text { Pyrophoric materials contained in waste } \\
\text { shall be treated, prepared, and packaged to } \\
\text { be nonflammable. }\end{array}$ & The requirements are the same. \\
\hline Waste Form & $\begin{array}{l}10 \mathrm{CFR} \\
61.56(\mathrm{a})(7)\end{array}$ & $\begin{array}{l}\text { Waste in a gaseous form must be packaged } \\
\text { at a pressure that does not exceed } 1.5 \\
\text { atmospheres at } 20^{\circ} \mathrm{C} \text {. Total activity must } \\
\text { not exceed } 100 \mathrm{Ci} \text { per container. }\end{array}$ & $\begin{array}{l}\text { DOE Order } \\
5820.2 \mathrm{~A} \\
\text { Chapter III } \\
3 \mathrm{i}(5)(\mathrm{c})\end{array}$ & $\begin{array}{l}\text { (e) Waste in a gaseous form must be } \\
\text { packaged at a pressure that does not exceed } \\
1.5 \text { atmospheres at } 20^{\circ} \mathrm{C} \text {. }\end{array}$ & $\begin{array}{l}\text { The criteria are the same except the NRC } \\
\text { specifies the maximum number of curies per } \\
\text { container. The DOE leaves waste } \\
\text { acceptance criteria to be decided by a } \\
\text { site-specific performance assessment. }\end{array}$ \\
\hline Waste Form & $\begin{array}{l}10 \text { CFR } \\
61.56(a)(8)\end{array}$ & $\begin{array}{l}\text { Waste containing hazardous, biological, } \\
\text { pathogenic, or infectious material must be } \\
\text { treated to reduce to the maximum extent } \\
\text { practicable the potential hazard from the } \\
\text { non-radiological materials. }\end{array}$ & $\begin{array}{l}\text { DOE Order } \\
5820.2 \mathrm{~A} \\
\text { Chapter III } \\
3 e(5)(f)\end{array}$ & $\begin{array}{l}\text { The waste acceptance criteria for storage, } \\
\text { treatment, or disposal facilities shall address } \\
\text { the following issues: (f) Chemical and } \\
\text { structural stability of waste packages, } \\
\text { radiation effects, microbial activity, } \\
\text { chemical reactions, and moisture. }\end{array}$ & $\begin{array}{l}\text { The intent of the two statements is to place } \\
\text { limiting criteria on these types of waste. } \\
\text { Neither is very prescriptive. The DOE } \\
\text { relies on the site-specific analysis to create } \\
\text { the limitations placed on these types of } \\
\text { waste. }\end{array}$ \\
\hline Waste Form & $\begin{array}{l}10 \mathrm{CFR} \\
61.56(b)(1)\end{array}$ & $\begin{array}{l}\text { Waste must have structural stability. A } \\
\text { structurally stable waste will generally } \\
\text { maintain its physical dimensions and its } \\
\text { form, under the expected disposal } \\
\text { conditions such as weight of overburden } \\
\text { and compaction equipment, the presence of } \\
\text { moisture, ... }\end{array}$ & $\begin{array}{l}\text { DOE Order } \\
5820.2 \mathrm{~A} \\
\text { Chapter III } \\
3 \mathrm{e}(5)(\mathrm{f})\end{array}$ & $\begin{array}{l}\text { The waste acceptance criteria for storage, } \\
\text { treatment, or disposal facilities shall address } \\
\text { the following issues: (f) Chemical and } \\
\text { structural stability of waste packages, } \\
\text { radiation effects, microbial activity, } \\
\text { chemical reactions, and moisture. }\end{array}$ & $\begin{array}{l}\text { The DOE establishes waste form } \\
\text { requirements based on site-specific } \\
\text { performance assessment results and reflects } \\
\text { those requirements in the facility waste } \\
\text { acceptance criteria. Unlike the NRC, DOE } \\
\text { does not impose mandatory waste } \\
\text { stabilization requirements. }\end{array}$ \\
\hline Waste Form & $\begin{array}{l}10 \mathrm{CFR} \\
61.56(\mathrm{~b})(2)\end{array}$ & $\begin{array}{l}\text { Not withstanding the provisions in } \\
61.56(a)(2) \text { and(3), liquid wastes, or wastes } \\
\text { containing liquid, must be converted into a } \\
\text { form that contains as little free standing } \\
\text { and noncorrosive liquid as is reasonably } \\
\text { achievable. }\end{array}$ & $\begin{array}{l}\text { DOE Order } \\
5820.2 \mathrm{~A} \\
\text { Chapter III } \\
3 \mathrm{i}(5)(\mathrm{b})\end{array}$ & $\begin{array}{l}\text { (b) Liquid wastes, or wastes containing free } \\
\text { liquid, must be converted into a form that } \\
\text { contains as little freestanding and } \\
\text { noncorrosive liquid as reasonably } \\
\text { achievable, but in no case, shall the liquid } \\
\text { exceed } 1 \% \text { of the volume of the waste when } \\
\text {... }\end{array}$ & $\begin{array}{l}\text { The statements are similar, but the NRC } \\
\text { restricts corrosive liquids, although it is not } \\
\text { prescriptive in defining what a corrosive } \\
\text { liquid is. }\end{array}$ \\
\hline Waste Form & $\begin{array}{l}10 \mathrm{CFR} \\
61.56(\mathrm{~b})(2)\end{array}$ & $\begin{array}{l}\text { In no case shall the liquid exceed } 1 \% \text { of the } \\
\text { volume of the waste when the waste is in a } \\
\text { disposal container designed to ensure } \\
\text { stability, or } 0.5 \% \text { of the volume of the } \\
\text { waste for waste processed to a stable form. }\end{array}$ & $\begin{array}{l}\text { DOE Order } \\
5820.2 \mathrm{~A} \\
\text { Chapter III } \\
3 \mathrm{i}(5)(\mathrm{b})\end{array}$ & $\begin{array}{l}\text { (b) Liquid wastes, or wastes containing free } \\
\text { liquid, must be converted into a form that } \\
\text { contains as little freestanding and } \\
\text { noncorrosive liquid as reasonably } \\
\text { achievable, but in no case, shall the liquid } \\
\text { exceed } 1 \% \text { of the volume of the waste when } \\
\text {... }\end{array}$ & The statements are the same. \\
\hline
\end{tabular}


Table B-1. (continued).

\begin{tabular}{|c|c|c|c|c|c|}
\hline Topic & NRC ref & Commercial requirement & DOE ref & DOE requirement & Discussion \\
\hline Waste Form & $\begin{array}{l}10 \mathrm{CFR} \\
61.56(\mathrm{~b})(3)\end{array}$ & $\begin{array}{l}\text { Void spaces within the waste and between } \\
\text { the waste and its package must be reduced } \\
\text { to the extent practicable. }\end{array}$ & $\begin{array}{l}\text { DOE Order } \\
5820.2 \mathrm{~A} \\
\text { Chapter III } \\
3 \mathrm{i}(9)(\mathrm{d})\end{array}$ & $\begin{array}{l}\text { Waste placement into disposal units should } \\
\text { minimize voids between containers. }\end{array}$ & $\begin{array}{l}\text { The DOE criteria does not address } \\
\text { minimizing the void space within the waste. } \\
\text { This an issue dealing with waste form } \\
\text { stability and is left to DOE site-specific } \\
\text { waste acceptance criteria, based on } \\
\text { performance assessment determination of } \\
\text { needs. }\end{array}$ \\
\hline Operations & 10 CFR 61.57 & $\begin{array}{l}\text { Each package of waste must be clearly } \\
\text { labeled to identify whether it is Class A } \\
\text { waste, Class B waste, or Class C waste, in } \\
\text { accordance with } 61.55 \text {. }\end{array}$ & $\mathrm{N} / \mathrm{A}$ & N/A & $\begin{array}{l}\text { DOE has chosen to address its waste on a } \\
\text { site-specific basis rather than having } \\
\text { pre-determined LLW classifications. } \\
\text { Therefore, it does not have these } \\
\text { designations. However, some DOE } \\
\text { facilities use similar LLW classification } \\
\text { systems. }\end{array}$ \\
\hline Waste Form & 10 CFR 61.58 & $\begin{array}{l}\text { The commission may, upon request or on } \\
\text { its own initiative, authorize other } \\
\text { provisions for the classification and } \\
\text { characteristics of waste on a specific basis, } \\
\text { if, after evaluation, of ...., it finds } \\
\text { reasonable assurance of compliance with } \\
\text { performance objective. }\end{array}$ & $\begin{array}{l}\text { DOE Order } \\
5820.2 \mathrm{~A}, \\
\text { Chapter III 3i(1) }\end{array}$ & $\begin{array}{l}\text { LLW shall be disposed of by methods } \\
\text { appropriate to achieve the performance } \\
\text { objectives stated in para. 3a, consistent with } \\
\text { the disposal site radiological performance } \\
\text { assessment in para. 3b. }\end{array}$ & $\begin{array}{l}\text { The DOE allows technical criteria developed } \\
\text { during the performance assessment to be } \\
\text { implemented in waste acceptance criteria } \\
\text { which is adopted into the safety envelope of } \\
\text { the operating facility. The NRC allows this } \\
\text { on an exception basis. }\end{array}$ \\
\hline Closure & 10 CFR 61.59(b) & $\begin{array}{l}\text { The land owner or custodial agency shall } \\
\text { carry out an institutional control program } \\
\text { to physically control access to the disposal } \\
\text { site following transfer of control of the } \\
\text { disposal site from the disposal site } \\
\text { operator. }\end{array}$ & $\begin{array}{l}\text { DOE Order } \\
5820.2 \mathrm{~A} \text {, } \\
\text { Chapter III } \\
3 \mathrm{i}(9)(\mathrm{a})\end{array}$ & $\begin{array}{l}\text { Field organizations. shall develop and } \\
\text { implement operating procedures for LLW } \\
\text { disposal facilities that protect the } \\
\text { environment, health and safety of the public, } \\
\text { and facility personnel; ensure the security of } \\
\text { the facility; minimize the need for long-term } \\
\text { control; and meet ... }\end{array}$ & $\begin{array}{l}\text { DOE requires the closure plan to establish } \\
\text { security requirements for the institutional } \\
\text { control period. }\end{array}$ \\
\hline Closure & 10 CFR $61.59(\mathrm{~b})$ & $\begin{array}{l}\text { The institutional control program must also } \\
\text { include, but not be limited to, carrying out } \\
\text { an environmental monitoring program at } \\
\text { the disposal site, periodic surveillance, } \\
\text { minor custodial care, and other } \\
\text { requirements as determined by the }\end{array}$ & $\begin{array}{l}\text { DOE Order } \\
5820.2 \mathrm{~A} \text {, } \\
\text { Chapter III } 3 \mathrm{j}(6)\end{array}$ & $\begin{array}{l}\text { Termination of monitoring and maintenance } \\
\text { activity at closed facilities or sites shall be } \\
\text { based on an analysis of site performance at } \\
\text { the end of the institutional control period. }\end{array}$ & $\begin{array}{l}\text { The DOE requires a minimum of } 100 \mathrm{yr} \text { of } \\
\text { monitoring and maintenance of the disposal } \\
\text { site. Further requirements for institutional } \\
\text { control will be established in the closure } \\
\text { plan which is completed prior to waste } \\
\text { receipt and continually maintained. }\end{array}$ \\
\hline
\end{tabular}


Table B-1. (continued).

\begin{tabular}{|c|c|c|c|c|c|}
\hline Topic & NRC ref & Commercial requirement & DOE ref & DOE requirement & Discussion \\
\hline Closure & 10 CFR 61.59(b) & $\begin{array}{l}\text { The period of institutional controls will be } \\
\text { determined by the Commission, but } \\
\text { institutional controls may not be relied } \\
\text { upon for more than } 100 \mathrm{yr} \text { following } \\
\text { transfer of control of the disposal site to the } \\
\text { owner. }\end{array}$ & $\begin{array}{l}\text { DOE Order } \\
5820.2 \mathrm{~A} \text {, } \\
\text { Chapter III } 3 \mathrm{j}(6)\end{array}$ & $\begin{array}{l}\text { Termination of monitoring and maintenance } \\
\text { activity at closed facilities or sites shall be } \\
\text { based on an analysis of site performance at } \\
\text { the end of the institutional control period. }\end{array}$ & $\begin{array}{l}\text { The DOE requires a minimum of } 100 \mathrm{yr} \text { of } \\
\text { monitoring and maintenance of the disposal } \\
\text { site. Further requirements for institutional } \\
\text { control will be established in the closure } \\
\text { plan which is completed prior to waste } \\
\text { receipt and continually maintained. }\end{array}$ \\
\hline Operations & 10 CFR $61.80(a)$ & $\begin{array}{l}\text { Each licensee shall maintain any records } \\
\text { and make any reports in connection with } \\
\text { the licensed activities as may be required } \\
\text { by the conditions of the license or by the } \\
\text { rules, regulations, and orders of the } \\
\text { Commission. }\end{array}$ & $\begin{array}{l}\text { DOE Order } \\
5820.2 \mathrm{~A} \\
\text { Chapter III } \\
3 \mathrm{~m}(1)\end{array}$ & $\begin{array}{l}\text { Each field organization shall develop and } \\
\text { maintain a record keeping system that } \\
\text { records: (a) historical record of waste } \\
\text { generated, treated, stored, shipped, disposed } \\
\text { of, or both, at the facilities under its } \\
\text { cognizance. }\end{array}$ & $\begin{array}{l}\text { The specifications for the DOE records is } \\
\text { less defined in DOE } 5820.2 \mathrm{~A} \text { than in } \\
10 \text { CFR } 61 \text {. Records requirements are } \\
\text { found in several other DOE orders. }\end{array}$ \\
\hline Operations & 10 CFR $61.80(b)$ & $\begin{array}{l}\text { Records which are required by the } \\
\text { regulations in this part or by license } \\
\text { conditions must be maintained for a period } \\
\text { specified by the appropriate regulations in } \\
\text { this chapter or by license condition. }\end{array}$ & $\begin{array}{l}\text { DOE Order } \\
5820.2 \mathrm{~A} \\
\text { Chapter III } \\
3 \mathrm{~m}(2)\end{array}$ & $\begin{array}{l}\text { Waste manifests shall be kept as permanent } \\
\text { records. The following data will be included } \\
\text { (a) waste physical and chemical } \\
\text { characteristics; (b) quantity of each } \\
\text { radionuclide; (c) weight of the waste; } \\
\text { (d) volume of the waste; (e) other data for } \\
\text { compliance with Waste Acceptance Criteria } \\
\text { (WAC)... }\end{array}$ & $\begin{array}{l}\text { Required records are not very well defined } \\
\text { in the } 5820.2 \mathrm{~A} \text { Order and it is not made } \\
\text { clear what document specifies required } \\
\text { records as done by NRC in license } \\
\text { requirements. }\end{array}$ \\
\hline Operations & 10 CFR $61.80(b)$ & $\begin{array}{l}\text { Records which are required by the } \\
\text { regulations in this part or by license } \\
\text { conditions must be maintained for a period } \\
\text { specified by the appropriate regulations in } \\
\text { this chapter or by license condition. }\end{array}$ & $\begin{array}{l}\text { DOE Order } \\
1324.2 B \text {, } \\
\text { Section } 1 \text {. }\end{array}$ & $\begin{array}{l}\text { To establish the DOE records management } \\
\text { policy and program for managing records. }\end{array}$ & $\begin{array}{l}\text { DOE Order } 1324.5 B \text { addresses records } \\
\text { management, but does not specifically } \\
\text { address the records management for a } \\
\text { low-level waste disposal facility. }\end{array}$ \\
\hline Operations & 10 CFR 61.80(b) & $\begin{array}{l}\text { If a retention period is not otherwise } \\
\text { specified, these records must be maintained } \\
\text { and transferred to the officials specified in }\end{array}$ & N/A & N/A & $\begin{array}{l}\text { Since DOE is both the owner and operator, } \\
\text { there is no transfer of records. }\end{array}$ \\
\hline
\end{tabular}


Table B-1. (continued).

\begin{tabular}{|c|c|c|c|c|c|}
\hline Topic & NRC ref & Commercial requirement & DOE ref & DOE requirement & Discussion \\
\hline Operations & 10 CFR $61.80(c)$ & $\begin{array}{l}\text { Records which must be maintained } \\
\text { pursuant to this part may be the original or } \\
\text { a reproduced copy or a microform if this } \\
\text { reproduced copy or microform is capable } \\
\text { producing copy that is clear and legible at } \\
\text { the end of the required retention period. } \\
\text { The record may also be stored in electronic } \\
\text { media with the capability for producing } \\
\text { legible, accurate, and complete records } \\
\text { during the required retention period. } \\
\text { Records such as letters, drawings, } \\
\text { specifications, must include all pertinent } \\
\text { information such as stamps, initials, and } \\
\text { signatures. }\end{array}$ & $\begin{array}{l}\text { DOE Order } \\
5820.2 \mathrm{~A} \text {, } \\
\text { Chapter III } \\
3 \mathrm{~m}(1)\end{array}$ & $\begin{array}{l}\text { The data maintained in the system shall be } \\
\text { based on data recorded on waste manifests. }\end{array}$ & $\begin{array}{l}\text { The DOE requirements for disposal records } \\
\text { does not identify any criteria for acceptable } \\
\text { records form. This may lead to very } \\
\text { different and non-uniform records keeping } \\
\text { across the DOE complex. }\end{array}$ \\
\hline Operations & 10 CFR $61.80(\mathrm{c})$ & $\begin{array}{l}\text { The licensee shall maintain adequate } \\
\text { safeguards against tampering with and loss } \\
\text { of records. }\end{array}$ & $\begin{array}{l}\text { DOE Order } \\
5820.2 \mathrm{~A} \text {, } \\
\text { Chapter III, 3m }\end{array}$ & $\begin{array}{l}\text { No information on safeguards for records } \\
\text { and reports is in Chapter III of DOE } \\
5820.2 \mathrm{~A} \text {. }\end{array}$ & $\begin{array}{l}\text { The DOE requirements for disposal records } \\
\text { does not identify any criteria for providing } \\
\text { safeguards against tampering and loss of } \\
\text { records. }\end{array}$ \\
\hline Operations & 10 CFR $61.80(\mathrm{e})$ & $\begin{array}{l}\text { Notwithstanding para. (a)-(d) of this } \\
\text { section, the licensee shall record the } \\
\text { location and the quantity of radioactive } \\
\text { wastes contained in the disposal site and } \\
\text { transfer these records upon license } \\
\text { termination to the chief executive of the } \\
\text { nearest municipality, the chief executive of } \\
\text { the county in which the facility is located, } \\
\text { the county zoning board or land ... }\end{array}$ & NA & NA & $\begin{array}{l}\text { There is no transfer of records in the DOE } \\
\text { system since they are both the owner and } \\
\text { operator. }\end{array}$ \\
\hline Operations & $10 \mathrm{CFR} 61.80(f)$ & $\begin{array}{l}\text { The licensee shall record the date that the } \\
\text { shipment is received at the disposal facility, } \\
\text { the date of disposal of the waste, a } \\
\text { traceable shipment manifest number, a } \\
\text { description of any engineered barrier or } \\
\text { structural overpack provided for disposal } \\
\text {... }\end{array}$ & $\begin{array}{l}\text { DOE Order } \\
5820.2 \mathrm{~A} \\
\text { Chapter III } \\
3 \mathrm{~m}(2)\end{array}$ & $\begin{array}{l}\text { Records shall be kept and accompany each } \\
\text { waste package from generator through final } \\
\text { disposal. The manifest shall contain data } \\
\text { necessary to document the proper } \\
\text { classification, and assist in determining } \\
\text { proper treatment, storage, and disposal of } \\
\text { the waste. Waste manifests shall be kept as } \\
\text { permanent records. The following data will } \\
\text { be included (a) waste physical and chemical } \\
\text { characteristics; (b) quantity of each } \\
\text { radionuclide; (c) weight of the waste; } \\
\text { (d) volume of the waste; (e) other data for } \\
\text { compliance with WAC... }\end{array}$ & $\begin{array}{l}\text { The intent of the requirements to maintain } \\
\text { needed records seems to be the same. The } \\
\text { NRC requirements are more specific. }\end{array}$ \\
\hline
\end{tabular}


Table B-1. (continued).

\begin{tabular}{|c|c|c|c|c|c|}
\hline Topic & NRC ref & Commercial requirement & DOE ref & DOE requirement & Discussion \\
\hline Operations & 10 CFR $61.80(\mathrm{~g})$ & $\begin{array}{l}\text { Each licensee shall comply with the } \\
\text { safeguards reporting requirements of } \\
30.55,40.64,70.53, \text { and } 70.54 \text { of this } \\
\text { chapter if the quantities or activities of } \\
\text { materials received or transferred exceed } \\
\text { the limits of these sections. }\end{array}$ & $\begin{array}{l}\text { Safeguards and } \\
\text { Security Orders }\end{array}$ & $\begin{array}{l}\text { DOE has specific Orders which address } \\
\text { reporting requirements for accountable } \\
\text { materials. These are DOE Order 5633.2A, } \\
\text { "Control and Accountability of Nuclear } \\
\text { Materials: Responsibilities and Authorities;" } \\
\text { DOE Order 5633.4, "Nuclear Materials } \\
\text { Transactions: Documentation and } \\
\text { Reporting;" and DOE Order 5633.5, } \\
\text { "Nuclear Materials Reporting and Data } \\
\text { Submission Procedures." }\end{array}$ & $\begin{array}{l}\text { DOE routinely keeps records for } \\
\text { accountable nuclear materials. }\end{array}$ \\
\hline Operations & $\begin{array}{l}10 \mathrm{CFR} \\
61.80(i)(1)\end{array}$ & $\begin{array}{l}\text { Each licensee authorized to dispose of } \\
\text { waste materials received from other } \\
\text { persons, pursuant to this part, shall submit } \\
\text { annual reports to the appropriate } \\
\text { Commission regional office shown in } \\
\text { Appendix D to } 10 \text { CFR 20, with copies to } \\
\text {... }\end{array}$ & $\begin{array}{l}\text { DOE Order } \\
\text { 5400.1, Chapter } \\
\text { II, 4.c }\end{array}$ & $\begin{array}{l}\text { All DOE facilities that conduct significant } \\
\text { environmental protection programs shall } \\
\text { prepare an Annual Site Environmental } \\
\text { Report. Environmental reports covering the } \\
\text { previous calendar year shall be prepared } \\
\text { annually and distributed by June } 1 \text { to EH-1, } \\
\text { appropriate PSOs,... }\end{array}$ & $\begin{array}{l}\text { Both agencies require an annual report } \\
\text { centered around environmental monitoring } \\
\text { results. }\end{array}$ \\
\hline Operations & $\begin{array}{l}10 \mathrm{CFR} \\
61.80(\mathrm{i})(2)\end{array}$ & $\begin{array}{l}\text { These annual reports shall include (i) } \\
\text { specification of the quantity of each of the } \\
\text { principal radionuclides released to } \\
\text { unrestricted areas in liquid and in airborne } \\
\text { effluents during the preceding year, (ii) } \\
\text { results of the environmental monitoring } \\
\text { program, (iii) a summary of licensee } \\
\text { disposal unit survey and maintenance } \\
\text { activities, (iv) a summary, by waste class, } \\
\text { of activities and quantities of radionuclides } \\
\text { disposed of, (v) any instances in which } \\
\text { observed site characteristics were } \\
\text { significantly different from those described } \\
\text { in the application for a license, and (vi) any } \\
\text { other information the commission may } \\
\text { require. }\end{array}$ & $\begin{array}{l}\text { DOE Order } \\
5400.1 \text {, } \\
\text { Attachment II-1 }\end{array}$ & $\begin{array}{l}\text { Content and format for the Annual Site } \\
\text { Environmental Report is provided in } \\
\text { Attachment II-1, Page II-5. }\end{array}$ & $\begin{array}{l}\text { Both the DOE and NRC report require the } \\
\text { results of the environmental monitoring } \\
\text { activities. The NRC report requirements are } \\
\text { written more specifically for a disposal } \\
\text { facility, whereas the DOE requirements are } \\
\text { written for any DOE activity requiring } \\
\text { environmental monitoring. }\end{array}$ \\
\hline Operations & $\begin{array}{l}10 \mathrm{CFR} \\
61.80(\mathrm{i})(2)\end{array}$ & $\begin{array}{l}\text { If the quantities of radioactive materials } \\
\text { released during the reporting period, } \\
\text { monitoring results, or maintenance } \\
\text { performed are significantly different from } \\
\text { those expected in the materials previously } \\
\text { reviewed as part of the licensing action, the } \\
\text { report must cover this specifically. }\end{array}$ & $\begin{array}{l}\text { DOE Order } \\
5400.1 \text { Chapter } \\
\text { II.5(b) }\end{array}$ & $\begin{array}{l}\text { Unplanned releases of radioactive materials } \\
\text { in effluents, such as spills, leaks, etc., } \\
\text { whether onsite or offsite, also shall be } \\
\text { reported to the Information System Branch, } \\
\text { on Form DOE F } 5821.1 \text {. This is in addition } \\
\text { to reporting requirement of DOE Order } \\
5000.3 \mathrm{~A} \text {. }\end{array}$ & $\begin{array}{l}\text { Both citations are intended to identify } \\
\text { unusual environmental releases. }\end{array}$ \\
\hline
\end{tabular}


Table B-1. (continued).

\begin{tabular}{ccllll}
\hline \multicolumn{2}{c}{ Topic } & NRC ref & \multicolumn{1}{c}{ Commercial requirement } & \multicolumn{1}{c}{ DOE ref } & \multicolumn{1}{c}{ DOE requirement } \\
\hline Operations & 10 CFR 61.80(j) & $\begin{array}{l}\text { Each licensee shall report in accordance } \\
\text { with the requirements of } 10 \mathrm{CFR} 70.52 \\
\text { (Reports of accidental criticality or loss or } \\
\text { theft or attempted theft of special nuclear }\end{array}$ & $\begin{array}{l}\text { DOE Order } \\
5000.3 \mathrm{~B},\end{array}$ & $\begin{array}{l}\text { Loss or apparent loss of one or more items } \\
\text { for which the items total a Category III or }\end{array}$ & $\begin{array}{l}\text { Both DOE and commercial facilities must } \\
\text { report loss of special nuclear material and } \\
\text { greater quantity of special nuclear material } \\
\text { is classified as an emergency or unusual }\end{array}$
\end{tabular}
material).

Operations $10 \mathrm{CFR} 61.80(\mathrm{k})$ Any transfer of byproduct, source, and special nuclear materials by the licensee is subject to the requirements of 10 CFR 30.41, 40.51, and 70.42 .

DOE Order 5633.3B Chapter I:1.a occurrence which must be reported as required in DOE Order 5000.3B.

Special nuclear material shall not be received, processed, or stored at a facility until facility approval has been granted in accordance with requirements of DOE Orde 5634.1B, Facility Approval, Security Surveys, and Nuclear Material Surveys.

Operations 10 CFR $61.80(1) \quad$ In addition to other requirements of this

Operations

10 CFR 61.82(a) section, the licensee shall store or have stored, manifest and other information pertaining to receipt and disposal of radioactive waste in an electronic recordkeeping system. Commission to perform, any tests as the Commission deems appropriate or necessary for the administration of the regulations of this part, including tests of: (1) radioactive wastes and facilities used ...

DOE Order

5820.2A,

Chapter III, 3m

Each field organization shall develop and maintain a recordkeeping system that

records the following: a historical record of

waste generated, treated, stored, shipped, disposed of ... The data maintained shall include all data necessary to show that the waste was properly classified, treated, stored, shipped, and/or disposed of. -.. Waste manifests shall be kept as permanent records.

\section{DOE Order \\ Consistent with DOE Order $5700.6 \mathrm{~B}$, the} 5820.2A, LLW operational and disposal practices shall be conducted in accordance with applicable requirements of ANSI/ASME NQA-1 and other appropriate national consensus

Each licensee shall afford to the DOE Order Commission at all reasonable times $\quad 5820.2 \mathrm{~A}$, opportunity to inspect radioactive waste not Chapter III 31 yet disposed of, and the premises,

equipment, operations, and facilities in which radioactive wastes are received, possessed, handled, ... standards.

Consistent with DOE Order 5700.6B, the

LLW operational and disposal practices shatl

be conducted in accordance with applicable requirements of ANSI/ASME NQA-1 and other appropriate national consensus standards.
Both citations place qualification requirements upon parties transferring nuclear material.

The intent of these requirements appears to be the same.

This requirement points out the difference between the NRC and DOE systems for oversight. The NRC has oversight by an independent agency and the DOE utilizes contractor and DOE quality assurance programs to implement oversight.

This requirement points out the difference between the NRC and DOE systems for oversight. The NRC has oversight by an independent agency and the DOE utilizes contractor and DOE quality assurance programs to implement oversight. 
Table B-1. (continued).

\begin{tabular}{|c|c|c|c|c|c|}
\hline Topic & NRC ref & Commercial requirement & DOE ref & DOE requirement & Discussion \\
\hline Operations & 10 CFR 61.82(b) & $\begin{array}{l}\text { Each licensee shall make available to the } \\
\text { Commission for inspection, upon } \\
\text { reasonable notice, records kept by it } \\
\text { pursuant to the regulations in this chapter. }\end{array}$ & $\begin{array}{l}\text { DOE Order } \\
5820.2 \mathrm{~A}, \\
\text { Chapter III } 31\end{array}$ & $\begin{array}{l}\text { Consistent with DOE Order } 5700.6 \mathrm{~B} \text {, the } \\
\text { LLW operational and disposal practices shall } \\
\text { be conducted in accordance with applicable } \\
\text { requirements of ANSI/ASME NQA-1 and } \\
\text { other appropriate national consensus } \\
\text { standards. }\end{array}$ & $\begin{array}{l}\text { This requirement points out the difference } \\
\text { between the NRC and DOE systems for } \\
\text { oversight. The NRC has oversight by an } \\
\text { independent agency and the DOE utilizes } \\
\text { contractor and DOE quality assurance } \\
\text { programs to implement oversight. }\end{array}$ \\
\hline Operations & 10 CFR 61.83(a) & $\begin{array}{l}\text { The Commission may obtain an injunction } \\
\text { or other court order to prevent a violation } \\
\text { of the provisions of (1) The Atomic Energy } \\
\text { Act of } 1954 \text {, as amended, (2) Title II of the } \\
\text { Energy Reorganization Act of } 1974 \text {, as } \\
\text { amended, (3) A regulation or order issued } \\
\text {... }\end{array}$ & $\begin{array}{l}\text { DOE Order } \\
5000.3 B \\
\text { Section } 6 .\end{array}$ & $\begin{array}{l}\text { It is the policy of the Depart...that } \\
\text { occurrences be consistently reported to } \\
\text { ensure...management are kept fully and } \\
\text { currently informed of all events... It is also } \\
\text { the policy of the Dept. that there be a system } \\
\text { for determining appropriate corrective action } \\
\text { and ... }\end{array}$ & $\begin{array}{l}\text { DOE has established an occurrence } \\
\text { reporting system which required early } \\
\text { notification to both DOE and contractor line } \\
\text { management of occurrences and a } \\
\text { documented root cause analysis to ensure } \\
\text { that appropriate immediate and long-term } \\
\text { action is taken. }\end{array}$ \\
\hline
\end{tabular}




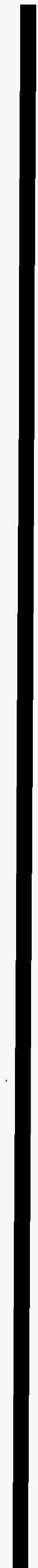


Appendix C

Comparison of Non-DOE and DOE

Waste Acceptance Criteria 


\section{Appendix C}

\section{Comparison of Non-DOE and DOE Waste Acceptance Criteria}

A comparison of waste acceptance criteria for the existing Barnwell and Richland commercial disposal facilities and four DOE disposal facilities is shown in Table C-1. The intent of the comparison is to determine if DOE and commercial facilities are different for similar waste acceptance parameters. The comparison only serves as a brief comparison of a few selected areas.

To effect a comparison, reviewers had to establish parameters to be compared. Realizing that these parameters are arbitrary, reviewers elected to use the parameters from a previous work. Comparison parameters were taken from:

Thomas A. Kerr, Matrix and Cross-References For Current, Former, and Proposed/Suggested Low-Level Radioactive Waste Acceptance Criteria, National Low-Level Waste Management Program, Idaho National Engineering Laboratory, Lockheed Idaho Technologies Company, Revision 4, February 9, 1995.

The above document was established to compare waste acceptance criteria of existing, former, and proposed commercial disposal facilities and has been used by proposed commercial sites as an information source while preparing their waste acceptance criteria. The information, from the original work, for the Richland and Barnwell commercial facilities was kept for this comparison and four DOE facilities were chosen to add to the table for comparison to the two commercial facilities. The DOE facilities chosen represent two arid sites and two humid sites.

The following documents were used as sources for the waste acceptance criteria that appear in the matrix:

Nuclear Regulatory

Commission

Barnwell, South Carolina
1. Title 10 of the Code of Federal Regulations Part 61

2. Title 10 of the Code of Federal Regulations Part 20 Appendix F

3. Technical Position on Waste Form, Revision 1, January 1991 (Abbreviation Used in Matrix: BTP)

1. South Carolina Department of Health and Environmental Control Radioactive Material License \#097 Amendment 45 (Abbreviation Used in Matrix: SCL)

2. U.S. Nuclear Regulatory Commission License \#12-13536-01 Amendment 24 (Abbreviation Used in Matrix: NRCL)

3. Barnwell Waste Management Facility Site Disposal Criteria (ChemNuclear Systems, Inc. Document \# S20-AD-010 Revision 8) (Abbreviation Used in Matrix: BSC) 
Richland,

Washington

DOE Nevada Test Site

(NTS)

DOE Oak Ridge National Laboratory

DOE Savannah River

DOE Hanford
1. State of Washington Radioactive Materials License \#WN-I019-2 Amendment \#18 (Abbreviation Used in Matrix: WAL)

2. U.S. Nuclear Regulatory Commission License \#16-19204-01 Amendment 11 (Abbreviation Used in Matrix: NRCL)

3. State of Washington Administrative Code 246-249-080 (for NORM)

1. Nevada Test Site Defense Waste Acceptance Criteria, Certification, and Transfer Requirements, NVO-325, Revision 1, June 1992.

1. Waste Acceptance Criteria For Radioactive Solid Waste Disposal at SWSA-6, WMRA-WMPC-203, Martin Marietta Energy Systems, Inc., Oak Ridge Tennessee, April 1993.

1. Savannah River Site Waste Acceptance Criteria Manual, 1S Manual, Chapter 3.10, E-Area Vaults Low-Level Waste Acceptance Criteria, May 21, 1995.

1. Hanford Site Solid Waste Acceptance Criteria, WHC-EP-0063-4 dated November 1993, through Page Change \#3, dated May 17, 1995. 
Table C-1. Comparison of non-DOE and DOE WAC.

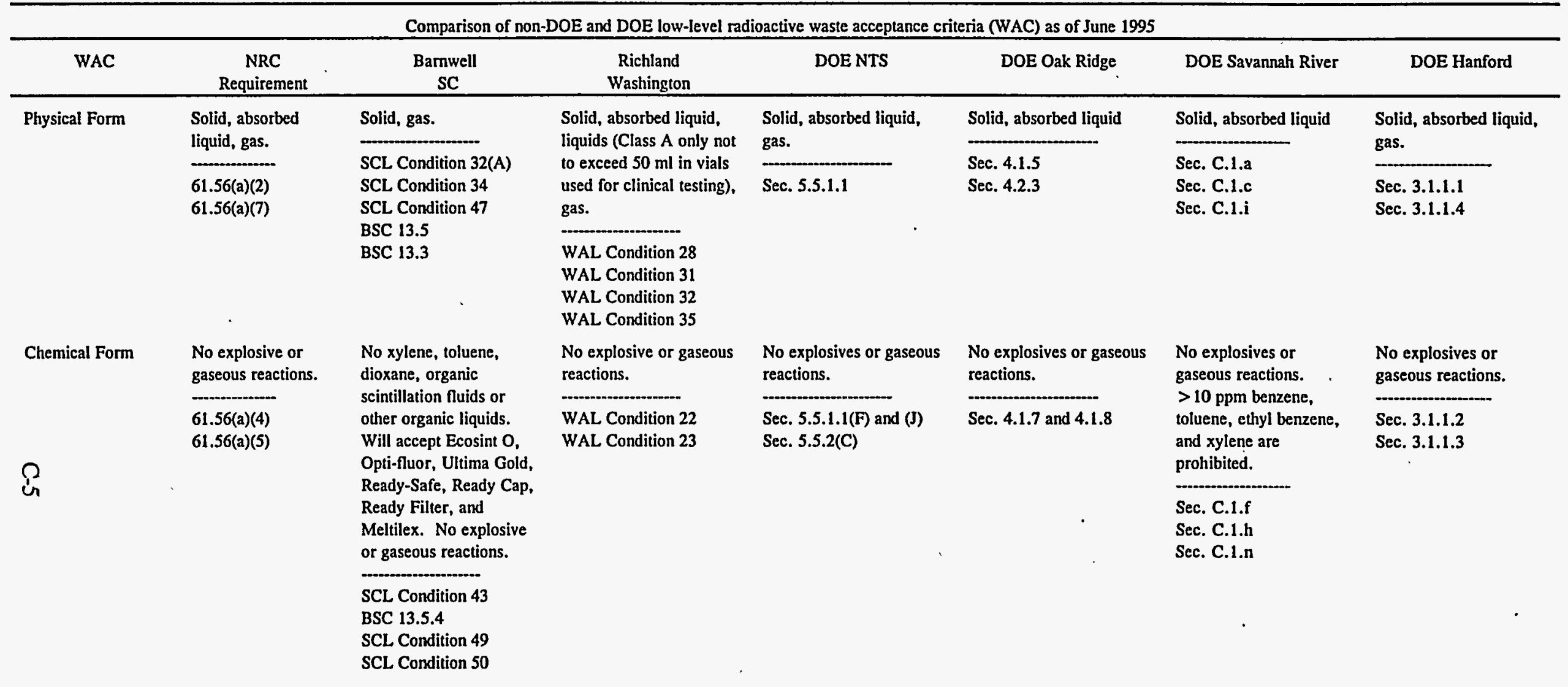

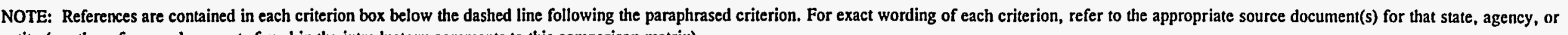
entity (see the reference documents found in the introductory comments to this comparison matrix). 
Table C-1. (continued).

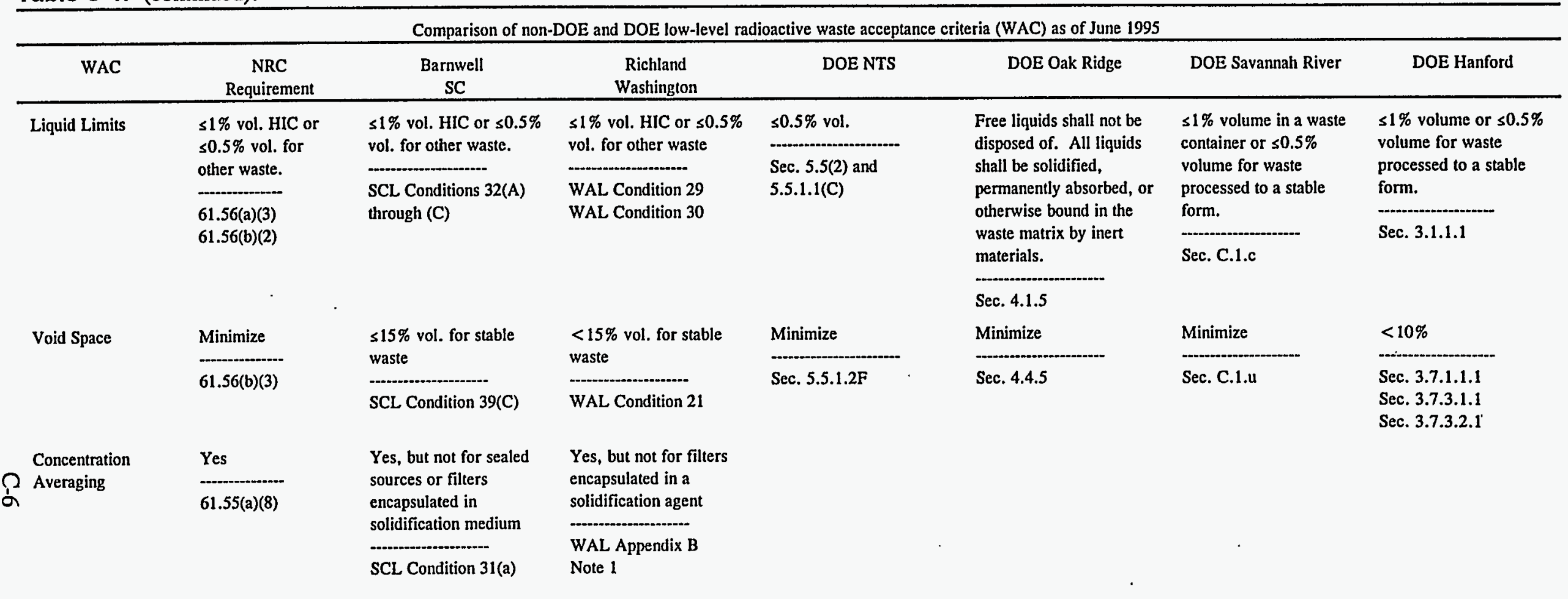


Table C-1. (continued).

Comparison of non-DOE and DOE low-level radioactive waste acceptance criteria (WAC) as of June 1995

\begin{tabular}{|c|c|c|c|c|c|c|c|}
\hline WAC & $\begin{array}{c}\text { NRC } \\
\text { Requirement }\end{array}$ & $\begin{array}{c}\text { Bamwell } \\
\text { SC }\end{array}$ & $\begin{array}{c}\text { Richland } \\
\text { Washington }\end{array}$ & DOE NTS & DOE Oak Ridge & DOE Savannah River & DOE Hanford \\
\hline \multirow[t]{2}{*}{ Packaging } & $\begin{array}{l}\begin{array}{l}\text { No cardboard or } \\
\text { fiberboard }\end{array} \\
61.56(\mathrm{a})(1)\end{array}$ & $\begin{array}{l}\text { No cardboard, } \\
\text { cornugated paper, or } \\
\text { fiberboard. Must be in } \\
\text { wood, steel, or HIC. All } \\
\text { packages must have } \\
\text { proper lifting devices in } \\
\text { place. } \\
\text { BSC } 8.7 \\
\text { BSC } 8.8 \\
\text { BSC } 8.9 \\
\text { SCL Condition } 60 \\
\text { SCL Condition } 61 \\
\text { SCL Condition } 64\end{array}$ & $\begin{array}{l}\text { No cardboard, } \\
\text { corrugated paper, } \\
\text { fiberboard or wood. All } \\
\text { packages must have } \\
\text { proper lifting devices in } \\
\text { place. } \\
\text { WAL Condition } 18 \\
\text { WAL Condition } 25\end{array}$ & $\begin{array}{l}\text { Except for bulk waste, } \\
\text { waste packaged in steel } \\
\text { drums or SEALAND } \\
\text { containers, the waste } \\
\text { package (packaging and } \\
\text { contents) shall be capable } \\
\text { of supporting a uniformly } \\
\text { distributed load of } \\
19,528 \mathrm{~kg} / \mathrm{m}^{2} \text {. All } \\
\text { packages must have } \\
\text { proper lifting devices in } \\
\text { place. } \\
\text { Sec. } 5.5 .1 .3(B) \text { and (C) }\end{array}$ & $\begin{array}{l}\text { No cardboard or } \\
\text { fiberboard unless such } \\
\text { boxes meet DOT } \\
\text { requirements and contain } \\
\text { stabilized waste with a } \\
\text { minimum of void space. } \\
\text { Sec.4.4.9 }\end{array}$ & $\begin{array}{l}\text { Factor of safety of } 2: 1 \\
\text { based on maximum } \\
\text { load. Containers must } \\
\text { be approved by disposal } \\
\text { facility. } \\
\text { Sec. C.7.c } \\
\text { Sec. C.7.e }\end{array}$ & $\begin{array}{l}\text { No cardboard or } \\
\text { fiberboard boxes unless } \\
\text { such boxes meet DOT } \\
\text { requirements and } \\
\text { contain stabilized waste } \\
\text { with a minimum of } \\
\text { void space. Package } \\
\text { must be metal or shall } \\
\text { be fire retardant. } \\
\text { Packages must be able } \\
\text { to withstand the weight } \\
\text { of three layers of } \\
55 \text {-gal drums (1,000 lb } \\
\text { per drum). All } \\
\text { packages must have } \\
\text { proper lifting devices in } \\
\text { place. }\end{array}$ \\
\hline & . & & & & & & $\begin{array}{l}\text { Sec. } 3.7 .1 .1 .1 \\
\text { Sec. } 3.7 .1 .2 .7 .8 \\
\text { Sec. } 3.7 .2 .3 .1\end{array}$ \\
\hline \multirow[t]{2}{*}{ Chelating Agents } & $\begin{array}{l}>0.1 \% \text { must be } \\
\text { identified and } \\
\text { estimated } \\
20 \text { App. F (I) }\end{array}$ & $\begin{array}{l}\text { \$8\% by weight. } \\
\text { Between } 0.1 \% \text { and } 8 \% \\
\text { must be stabilized. } \% \\
\text { applies prior to } \\
\text { solidification. }\end{array}$ & $\begin{array}{l}\text { Solidify or stabilize } \\
\text { pretreatment } \\
\text { concentration of }>1 \% \\
\text { by weight }\end{array}$ & $\begin{array}{c}\text { s1\% by weight } \\
\text { Sec. } 5.5 .1 .1(\mathrm{H})\end{array}$ & $\frac{s 0.1 \% \text { by weight }}{\text { Sec. } 4.2 .5}$ & $\begin{array}{l}>0.1 \% \text { by weight must } \\
\text { be stabilized; }>1 \% \text { by } \\
\text { weight is prohibited. }\end{array}$ & $\begin{array}{l}>1 \% \text { by weight must } \\
\text { be stabilized and } \\
\text { approved on a case-by- } \\
\text { case basis. }\end{array}$ \\
\hline & & $\begin{array}{l}\text { SCL Condition } 46 \\
\text { BSC } 13.16\end{array}$ & WAL Condition 41 & & & Sec. C.1.1 & $\begin{array}{l}\text { Sec. 3.1.2.4 } \\
\text { Sec. 3.9.2.7 }\end{array}$ \\
\hline
\end{tabular}


Table C-1. (continued).

\begin{tabular}{|c|c|c|c|c|c|c|c|}
\hline \multicolumn{8}{|c|}{ Comparison of non-DOE and DOE low-level radioactive waste acceptance criteria (WAC) as of June 1995} \\
\hline WAC & $\begin{array}{c}\text { NRC } \\
\text { Requirement } \\
\end{array}$ & $\begin{array}{c}\text { Barnwell } \\
\text { SC } \\
\end{array}$ & $\begin{array}{c}\text { Richland } \\
\text { Washington }\end{array}$ & DOE NTS & DOE Oak Ridge & DOE Savannah River & DOE Hanford \\
\hline Solidification Media & $\begin{array}{l}\text { Test in accordance } \\
\text { with Branch } \\
\text { Technical Position } \\
\text { on Waste Form } \\
\text { BTP }\end{array}$ & $\begin{array}{l}\text { Vinyl ester styrene, } \\
\text { cement, full-formula } \\
\text { oxidized bitumen, vinyl } \\
\text { chloride for stable } \\
\text { waste. Aquaset II-H and } \\
\text { 'tetroset II may be used } \\
\text { for Class A Unstable. } \\
\text { SCL Conditions 33(A) } \\
\text { through (E) } \\
\text { BSC 13.5.2 }\end{array}$ & $\begin{array}{l}\text { Aztech, oxidized } \\
\text { bitumen, concrete, vinyl } \\
\text { ester styrene for stable } \\
\text { waste. In addition to } \\
\text { these, Atcor cement, } \\
\text { Aquaset I and II, } \\
\text { straight-distilled } \\
\text { bitumen, Chem-Nuclear } \\
\text { cement, structural } \\
\text { concrete, Delaware } \\
\text { Custom Media, } \\
\text { Envirostone, LN } \\
\text { Technologies Portland } \\
\text { Cement for Oils, Pacific } \\
\text { Nuclear Cement, } \\
\text { Petroset I and II, Safe T } \\
\text { Set, and SEG Cement } \\
\text { may be used for Class A } \\
\text { Unstable. } \\
\text { W--.-.-.-... } \\
\text { WAL Appendix C } \\
\text { WAL Appendix D }\end{array}$ & $\begin{array}{l}\text { Chemical stability must } \\
\text { be documented to show } \\
\text { that significant quantities } \\
\text { of harmful gases, vapors, } \\
\text { or liquids are not } \\
\text { generated. } \\
\text { Sec. } 5.5 .1 .1(F)\end{array}$ & $\begin{array}{l}\text { The waste form shall be } \\
\text { stable under the presence } \\
\text { of moisture, microbial } \\
\text { activity, and intemal } \\
\text { factors such as radiation } \\
\text { effects and chemical } \\
\text { changes. } \\
\text { Sec. } 4.1 .10\end{array}$ & & $\begin{array}{l}\text { Category } 3 \text { LLW may } \\
\text { be solidified using a } \\
\text { NRC or } \\
\text { WHC-approved } \\
\text { process to meet } \\
\text { stability criteria. Final } \\
\text { processed waste must } \\
\text { satisfy the performance } \\
\text { criteria of the NRC } \\
\text { Teclunical Position } \\
\text { Paper on Waste Form. } \\
\text { Sec. 3.5.2.3 }\end{array}$ \\
\hline $\begin{array}{l}\text { Stability } \\
\text { Requirements }\end{array}$ & $\begin{array}{l}\text { HIC, inherent } \\
\text { characteristics or } \\
\text { process Class B and } \\
\text { C } \\
61.56(b)(1)\end{array}$ & $\begin{array}{l}\text { HIC, inherent } \\
\text { characteristics or } \\
\text { process Class B and C } \\
\text { and A if it has nuclides } \\
\text { with }>5 \text { yr half-life at } \\
21 \mu \mathrm{Ci} / \mathrm{cc} \\
\text { SCL Condition 33(B) } \\
\text { SCL Condition 38 } \\
\text { SCL Conditions 39(A) } \\
\text { and (B) } \\
\text { BSC } 8.1 \text { NOTE }\end{array}$ & $\begin{array}{l}\text { HIC, inherent } \\
\text { characteristics or } \\
\text { process Class B and C } \\
\text { and A if it is IX resin } \\
\text { with } 21 \mu \mathrm{ci} / \mathrm{cc} \text { of } \\
\text { nuclides with }>5 \mathrm{yr} \\
\text { half-life (Co- } 60 \text { can be } \\
550 \mu \mathrm{ci} / \mathrm{cc}) \\
------- \\
\text { WAL Condition } 26(\mathrm{D}) \\
\text { WAL Appendix D } \\
\text { WAL Appendix E } \\
\text { WAL Condition } 36\end{array}$ & $\begin{array}{l}\text { Where stabilization is } \\
\text { required, it must be } \\
\text { shown that the } \\
\text { stabilization process is } \\
\text { adequately controlled. } \\
\text { Control is shown through } \\
\text { the use of procedures, } \\
\text { sampling, test plans, etc. } \\
\text { and the results shall be } \\
\text { made available for } \\
\text { examination and } \\
\text { approval. } \\
\text { Sec. } 5.5 .1 .1(\mathrm{~F})\end{array}$ & $\begin{array}{l}\text { All liquids shall be } \\
\text { solidified, permanently } \\
\text { absorbed, or otherwise } \\
\text { bound in the waste matrix } \\
\text { by inert materials. } \\
\text { Sec. } 4.1 .5\end{array}$ & & $\begin{array}{l}\text { HIC, inherent } \\
\text { characteristics as } \\
\text { shown by analysis. All } \\
\text { Category } 3 \text { waste must } \\
\text { be stabilized. } \\
\text { Sec. } 3.5 .2 .1\end{array}$ \\
\hline
\end{tabular}


Table C-1. (continued).

\begin{tabular}{|c|c|c|c|c|c|c|c|}
\hline \multicolumn{8}{|c|}{ Comparison of non-DOE and DOE low-level radioactive waste acceptance criteria (WAC) as of June 1995} \\
\hline WAC & $\begin{array}{c}\text { NRC } \\
\text { Requirement }\end{array}$ & $\begin{array}{c}\text { Barnwell } \\
\text { SC } \\
\end{array}$ & $\begin{array}{c}\text { Richland } \\
\text { Washington }\end{array}$ & DOE NTS & DOE Oak Ridge & DOE Savannah River & DOE Hanford \\
\hline \multirow[t]{3}{*}{ Sorptive Media } & \multirow[t]{6}{*}{$\frac{\text { Allowable }}{-61.56(a)(2)}$} & \multirow{3}{*}{$\begin{array}{l}\text { Use only for incidental } \\
\text { and unintentional liquid } \\
\text { in otherwise dry solids } \\
\text { SCL Condition 32(A) } \\
\text { SCL Condition } 34\end{array}$} & \multirow{3}{*}{$\begin{array}{l}\text { May be used for liquids } \\
\text { and listed in Appendix G } \\
\text { of license WN-I019-2 } \\
\text { Amendment } 18 \text {. } \\
\text { Includes many clays, } \\
\text { diatomaceous earths, } \\
\text { perlites, and others } \\
\text { WAL Appendix G }\end{array}$} & \multirow{3}{*}{$\begin{array}{l}\text { Allowable, but types not } \\
\text { specified. } \\
\text { Sec. } 5.5 .1 .1(\mathrm{C})\end{array}$} & \multirow{3}{*}{$\begin{array}{l}\text { Allowable, but types not } \\
\text { specified. } \\
\text { Sec. } 4.1 .5\end{array}$} & \multirow{3}{*}{$\begin{array}{l}\text { Allowable, but types } \\
\text { not specified. } \\
\text { Sec. C.1.c }\end{array}$} & \multirow{3}{*}{$\begin{array}{l}\text { Allowable, acceptable } \\
\text { absorbents specified. } \\
\text { Sec. } 3.1 .1 .1 \\
\text { Sec. } 3.9 .1 .1 \\
\text { Sec. } 3.9 .2 .1 \\
\text { Appendix G }\end{array}$} \\
\hline & & & & & & & \\
\hline & & & & & & & \\
\hline Oil & & \multirow[t]{3}{*}{$\begin{array}{l}\text { s1\% vol. trace and } \\
\text { unintentional } \\
\text { BSC } 13.6 \\
\text { SCL Condition } 52\end{array}$} & \multirow{3}{*}{$\begin{array}{l}\text { Solidify or stabilize } \\
\text { pretreatment } \\
\text { concentration of }>10 \% \\
\text { by weight } \\
\text { WAL Condition } 40\end{array}$} & & \multirow{3}{*}{$\begin{array}{l}\text { The absence of free } \\
\text { liquids (including solvents } \\
\text { and oils) must be } \\
\text { certified for wastes which } \\
\text { are in solid form. } \\
\text { Sec. } 4.2(1)\end{array}$} & \multirow[t]{3}{*}{$\begin{array}{l}\text { Materials }>100 \mathrm{ppm} \\
\text { total petroleum } \\
\text { hydrocarbons are } \\
\text { prohibited. } \\
\text { Sec. C.1.m }\end{array}$} & \multirow{3}{*}{$\begin{array}{l}\text { Nonregulated free } \\
\text { organic liquids will not } \\
\text { be accepted. Absorbed } \\
\text { or stabilized organic } \\
\text { liquids may be } \\
\text { accepted with evidence } \\
\text { that the organic liquid } \\
\text { will not facilitate } \\
\text { migration of } \\
\text { radionuclides. }\end{array}$} \\
\hline & & & & & & & \\
\hline & & & & & & & \\
\hline \multirow[t]{4}{*}{ Gas } & \multirow{4}{*}{$\begin{array}{l}\leq 1.5 \text { atm. at } 20^{\circ} \mathrm{C} \\
\text { and } \max .100 \mathrm{Ci} \\
61.56(\mathrm{a})(7)\end{array}$} & \multirow{4}{*}{$\begin{array}{l}\mathrm{Kr}-85 \text { and } \mathrm{Xe}-133 \text { at } \\
\mathrm{s} 1.5 \mathrm{~atm} . \text { at } 20^{\circ} \mathrm{C} \text { and } \\
\text { max. } 100 \mathrm{Ci} \text {. Sealed } \\
\text { tritium gas sources } \\
\text { s1000 Ci. } \\
\text { SCL Condition } 47 \\
\text { BSC } 13.3\end{array}$} & \multirow{4}{*}{$\begin{array}{l}\text { s1.5 atm. at. } 20^{\circ} \mathrm{C} \text { and } \\
\text { max. } 100 \mathrm{Ci} \text {. } \\
\text { WAL Condition } 35\end{array}$} & $\$ 1.5 \mathrm{~atm}$. at $20^{\circ} \mathrm{C}$ & \multirow{2}{*}{$\begin{array}{l}1.5 \text { atm at } 20^{\circ} \mathrm{C} \text {. } \\
\text { Unpunctured aerosol cans } \\
\text { or gas cylinders are } \\
\text { prohibited. }\end{array}$} & \multirow{2}{*}{$\begin{array}{l}51.5 \text { atm. at } 20^{\circ} \mathrm{C} \text {. } \\
\text { Unpunctured aerosol } \\
\text { cans or gas cylinders } \\
\text { are prohibited. }\end{array}$} & $\leq 1.5 \mathrm{~atm}$. \\
\hline & & & & Sec. $5.5 .1 .1(E)$ & & & $\begin{array}{l}\text { Sec. 3.1.1.4 } \\
\text { Sec. 3.1.2.2 }\end{array}$ \\
\hline & & & & & Sec. 4.2(3) & Sec. C.1.i & \\
\hline & & & & & Sec. C.1.j & Sec. C.1.j & \\
\hline
\end{tabular}


Table C-1. (continued).

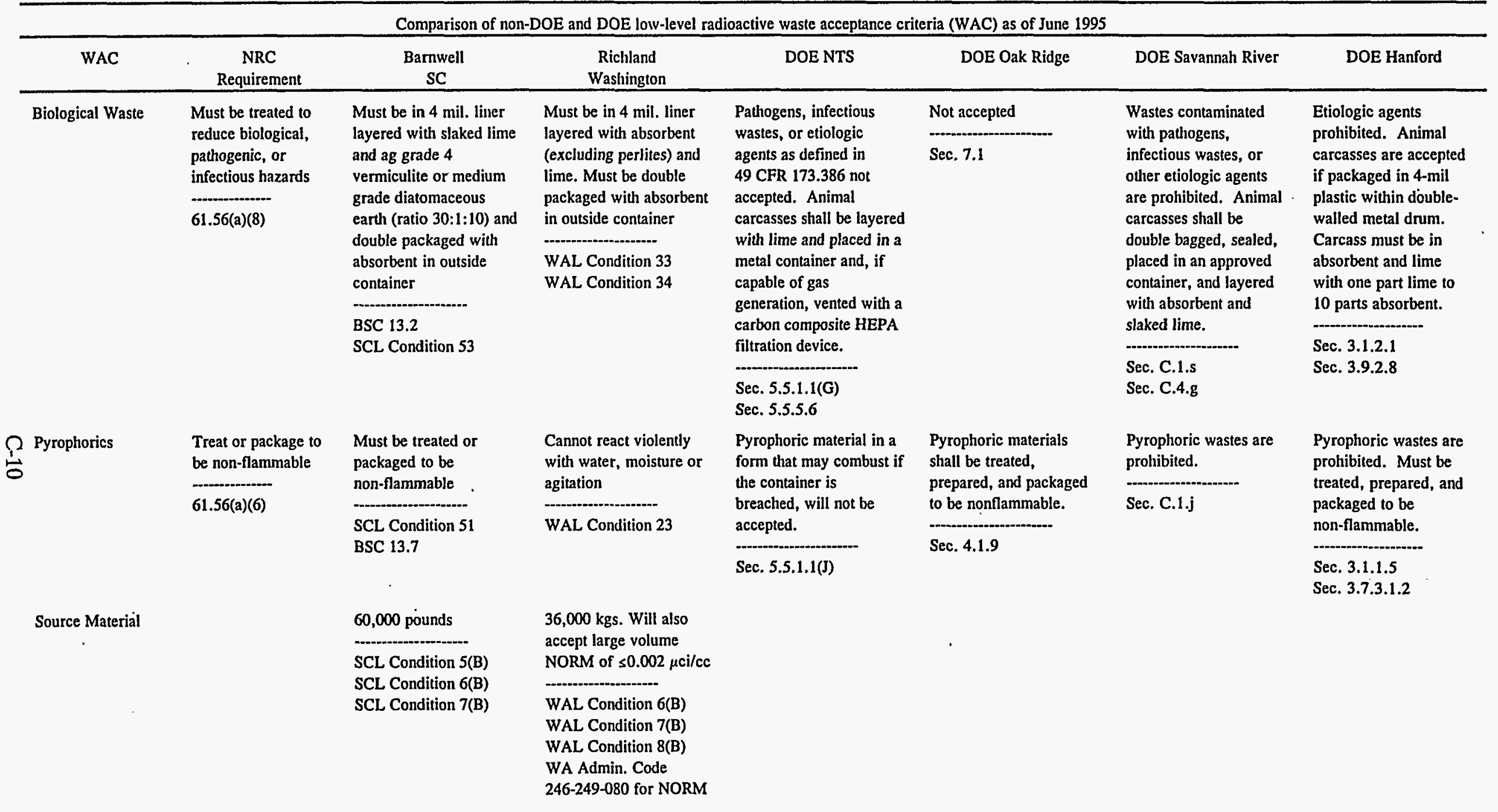


Table C-1. (continued).

Comparison of non-DOE and DOE low-level radioactive waste acceptance criteria (WAC) as of June 1995

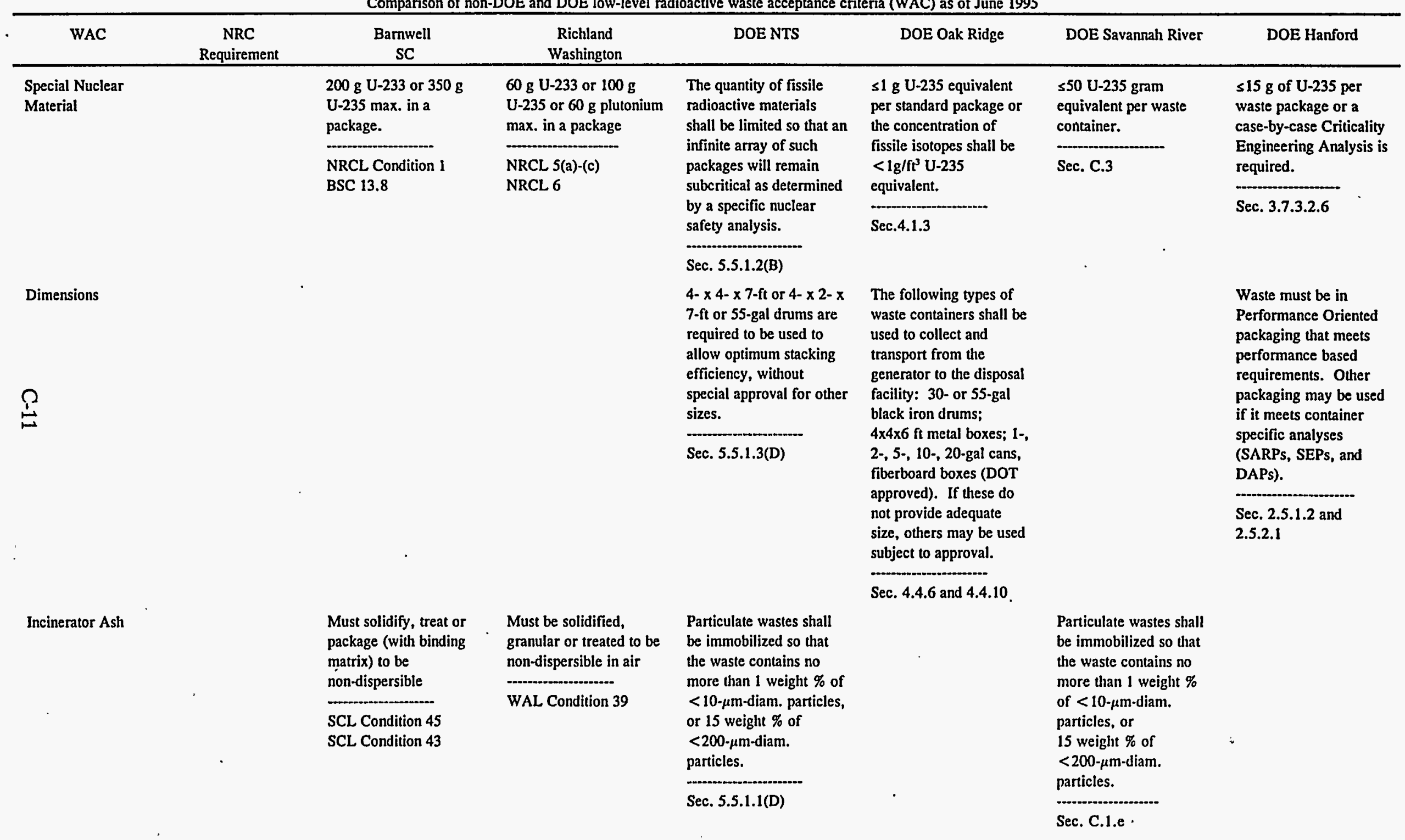


Table C-1. (continued).

Comparison of non-DOE and DOE low-level radioactive waste acceptance criteria (WAC) as of June 1995

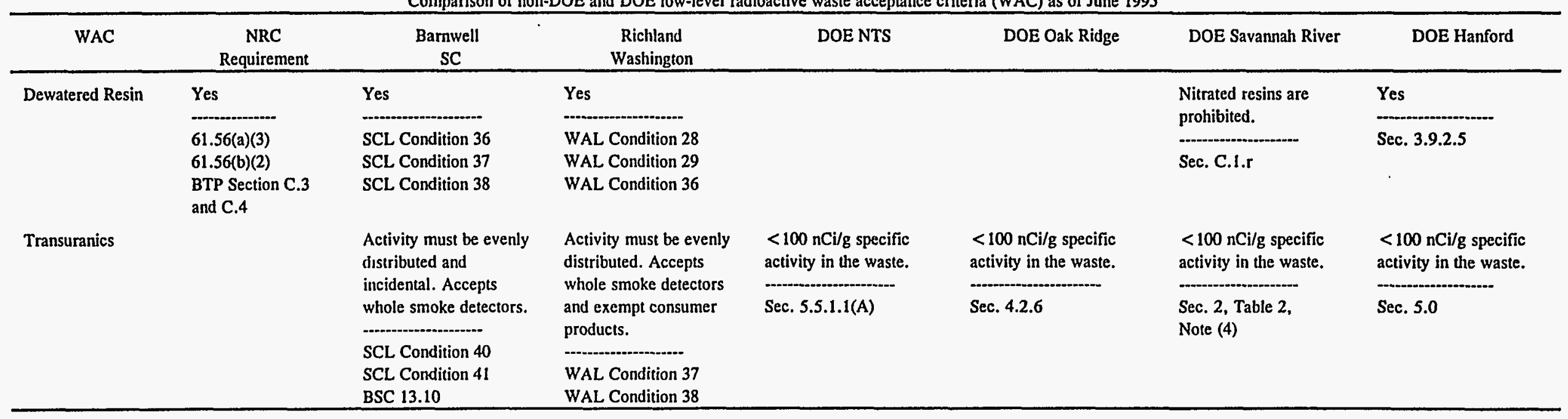

$\stackrel{\mathscr{N}}{\stackrel{\mathscr{N}}{ }}$ 


\section{Appendix D}

\section{Comparison of DOE and Non-DOE Performance}

Assessment Requirements, Guidance, and Practices

D-1 


\section{Appendix D}

\section{Comparison of DOE and Non-DOE Performance Assessment Requirements, Guidance, and Practices}

This appendix contains the DOE and non-DOE performance assessment information gathered to determine the differences in requirements, guidance, and practices. Because of the large volume of information it was not possible to put it all on one or two tables. The information was separated into six tables:

Table D-1. DOE performance assessment requirements and guidance.

Table D-2. Non-DOE performance assessment requirements and guidance.

Table D-3. DOE performance assessment practices, INEL (RWMC), and Hanford (200 West Area).

Table D-4. DOE performance assessment practices, ORNL (SWSA 6), and Savannah River Site (E-Area vaults).

Table D-5. Non-DOE performance assessment practices, Texas, California, and Nebraska.

Table D-6. Non-DOE performance assessment practices, North Carolina, Washington, and South Carolina.

The DOE performance assessment documents used were those that have been completed in at least a draft form and been reviewed by the performance assessment Peer Review Panel. Most of these documents have not been approved, work is continuing, and the information is subject to change. 
D-4 
Table D-1. DOE performance assessment requirements and guidance.

\begin{tabular}{|c|c|}
\hline Parameter & Requirement \\
\hline $\begin{array}{l}\frac{1 . \text { General }}{1.1 \text { Format and Content }} \\
\text { 1.1.1 What is the general format } \\
\text { and contents of the } P A ?\end{array}$ & $\begin{array}{l}\text { Field organizations with disposal sites shall } \\
\text { prepare and maintain a site-specific } \\
\text { radiological Performance Assessment (PA) for } \\
\text { the disposal of waste for the purpose of } \\
\text { demonstrating compliance with the } \\
\text { performance objectives. General assumptions } \\
\text { are required to determine the details of how the } \\
\text { receptor is exposed because of the following } \\
\text { requirements: "External exposure (of the } \\
\text { receptor) to the radioactive material that may } \\
\text { be released into surface water, ground water, } \\
\text { soil, plants and animals results in an EDE that } \\
\text { does not exceed ...," and "releases to } \\
\text { atmosphere shall meet the requirements of } \\
40 \text { CFR } 61 . " \text { (DOE 5820.2A) }\end{array}$ \\
\hline
\end{tabular}

\subsection{Approval Process \\ 1.2.1 What is the formal process for final approval of the $P A$ ?}

PAs for new LLW disposal facilities are reviewed by the responsible field element and submitted to the Deputy Assistant Secretary (DAS) for Waste Management before construction begins. Waste Management staff evaluate the PA and peer review panel (PRP) review documentation; consult with the Office of Environment, Safety, and Health; and make a recommendation to the Assistant Secretary For Environmental Management regarding compliance with the performance objectives of DOE Order 5820.2A. The Assistant Secretary for Environmental Management approves the PA and authorizes construction of the disposal facility. Upon acceptance of the PA, the DAS for Waste Management prepares a Disposal Authorization Statement that sets forth the conditions for design, construction, and operation of the disposal facility that are appropriate to ensure compliance with the LLW performance objectives. (Interim Policy, Reference 22.)

For existing LLW disposal facilities that continue to receive waste for disposal, PAs shall be reviewed by the responsible field element and subimitted to the DAS for Waste Management for initial acceptance according to a schedule provided by the DAS for Waste Management. Waste Management staff evaluate the PA and PRP reviews; consult with the Office of Environment, Safety and Health; and make a recommendation to the DAS for
Guidance

The recommended format and content of a PA is provided in DOE/LLW-62T $\mathrm{T}^{\mathrm{l}}$ and DOE/LLW-81. ${ }^{2}$ Additional recommendations are provided in DOE/LLW-93. ${ }^{3}$

a. The discussion included in the Guidance column often cites Reference 4, the Performance Assessment Task Team Progress Report. Readers should note that this document does not constitute official DOE guidance on how to prepare a performance assessment (PA). It does, however, represent the most recent (May 1994) documented recommendations of a DOE committee assembled to integrate the activities of the sites that are preparing PAs for disposal of low-level waste. 
Table D-1. (continued).

\begin{tabular}{ll}
\hline \multicolumn{1}{c}{ Parameter } & \multicolumn{1}{c}{ Requirement } \\
\hline 1.2 Approval Process & Waste Management about compliance with the \\
1.2.1 What is the formal process & performance objectives of DOE Order \\
for final approval of the PA? & 5820.2A. Upon PA acceptance, the DAS for \\
(continued) & Waste Management shall prepare a disposal \\
& authorization statement that sets forth the \\
conditions for operation of the disposal facility & that may be appropriate to ensure compliance \\
with the LLW performance objectives. & (Interim Policy, Reference 22.) \\
& Before final closure of the disposal facility, or \\
& as otherwise directed, a final version of the PA \\
shall be prepared, reviewed by the responsible & field element, and submitted to the DAS for \\
Waste Management for approval. (Interim & Policy, Reference 22.)
\end{tabular}

\subsection{Review Process}

1.3.1 What formal review process does the PA go through before submittal for approval?

\subsection{PA Maintenance}

1.4.1 Does the PA need to be reviewed and updated if parameters change?
PAs are reviewed by a PRP, at the request of the DAS for Waste Management. The purpose of this review is to ensure consistency and technical quality around the DOE complex in the development and application of performance assessment models that include site-specific geohydrology and waste composition. The PRP is selected by the DAS for Waste Management and is composed of DOE, contractor, and other specialists in PAs, with participation by representatives from the Office of Environment, Safety, and Health and operations offices. (Interim Policy,

Reference 22.)

Field offices having a disposal facility PA accepted by the DAS for Waste Management shall conduct a PA maintenance program during the operational period of the disposal facility. In addition, PAs shall be reviewed and revised when changes in waste forms or packaging, radionuclide inventories, facility design, closure concepts, or the understanding of the site or other features change the conclusions of the existing PA. On an annual basis, or as otherwise required, field offices will make a determination of the continued adequacy of the PA based on waste receipts, the results of monitoring or test programs, and other relevant factors. The determination must be documented and made available for inspection. (Interim Policy, Reference 22.)
A preliminary and a final review of the PA is done by a PRP. After the final review the PRP issues a judgment of the technical quality of the PA to EM-30. ${ }^{3}$ 
Table D-1. (continued).

Parameter

Requirement

Guidance $^{2}$

1.5 Method for Evaluating

Uncertainty

1.5.1 Is the method deterministic or probabilistic and what kind of uncertainty or sensitivity analysis is used?

\subsection{Computer Codes}

1.6.1 Is there an approval process for $P A$ codes that is separate from the $P A$ approval process? Is there a list of pre-approved codes?
There is no statement in DOE 5820.2A that is related to uncertainty of the $\mathrm{PA}$. The method of determining compliance with the performance objective is normally deterministic since the PA usually provides a single dose for comparison. Uncertainties are discussed in the PA, but the final calculated dose does not normally include a range of doses based on the uncertainties or the sensitivities.

There is no requirement or approval process for PA codes. Their results are approved as part of the PA approval process. There are no codes pre-approved for PA use.
1.6.2 Does the code approval process include validation and/or verification?

2. Recentor (most exposed individual

2.1 Recentor Scenario

2.1.1 What general assumptions are required?

\subsubsection{What site-specific assumptions are used?}

Not applicable.

None.

Not applicable.
Sensitivity of the PA results to various model assumptions and the analysis of uncertainty in the $P A$ results will be reviewed by the PRP. ${ }^{3}$ Guidelines on the performance of uncertainty analyses and sensitivity analyses is provided in DOE/LLW-62T.'

The PA must include a discussion of the rationale for selecting the computer codes that were used in the assessment. ${ }^{3}$ The PRP reviews the justification for using the codes. Many pages of discussion on selection and sources of PA computer codes is provided in DOE/LLW-62T ${ }^{1}$ and DOE/LLW-157.4 A listing of DOE and EPA PA modeling codes is also provided, however, the discussion states that these codes are too simplistic because they model the system with rather simplified descriptions of actual physical processes and/or with simplified submodels in order to make computer modeling feasible for an entire complex system.

A combination of verification and benchmark testing can be used to build confidence in the ability of the code and embodied model(s) to simulate macroscopic (plume scale) behavior of a site-specific disposal system. Such testing is necessary for all codes used in support of a PA. ${ }^{4}$

For compliance with the dose objectives the maximally exposed individual, during the periods of operations and institutional control, shall be a hypothetical adult individual residing at or near the DOE site boundary at the location of maximum exposure to radionuclides. ${ }^{1}$ The maximally exposed individual is assumed to be the ICRP reference man model. (DOE 5400.5)

See site-specific practices. 
Table D-1. (continued).

\begin{tabular}{|c|c|c|}
\hline Parameter & Requirement & Guidance $^{\mathrm{a}}$ \\
\hline $\begin{array}{l}\text { 2.1.3 Are variations used to model } \\
\text { against possible future } \\
\text { environmental conditions? }\end{array}$ & $\begin{array}{l}\text { There is no requirement on this in } \\
\text { DOE } 5820.2 \mathrm{~A} \text {. }\end{array}$ & $\begin{array}{l}\text { Each site PA should consider the effects of } \\
\text { expected long-term changes to the degree that } \\
\text { such changes may significantly impact the } \\
\text { isolation capability of their disposal systems } \\
\text { within the time period covered by the PA. } \\
\text { Events and processes with small impact and } \\
\text { probability should be omitted. Generally a } \\
\text { qualitative discussion will suffice. } \\
\text { To demonstrate compliance with the } \\
\text { performance objectives, long-term calculations } \\
\text { based on present conditions (including present } \\
\text { rates of natural processes such as erosion) } \\
\text { should be carried out. }\end{array}$ \\
\hline $\begin{array}{l}\text { 2.2 Dose Standard } \\
\text { 2.2.1 What is the dose standard } \\
\text { (performance objective) for the } \\
\text { most exposed individual? }\end{array}$ & $\begin{array}{l}\text { Assure that external exposure to the waste and } \\
\text { concentrations of radioactive material which } \\
\text { may be released into surface water, ground } \\
\text { water, soil, plants and animals results in an } \\
\text { EDE that does not exceed } 25 \text { mrem/yr to any } \\
\text { member of the public. Releases to the } \\
\text { atmosphere shall meet the requirements of } \\
40 \text { CFR } 61 \text {. Protect ground water resources, } \\
\text { consistent with Federal, State and local } \\
\text { requirements. (DOE 5820.2A) }\end{array}$ & $\begin{array}{l}\text { The PATT recommends that, "Disposal } \\
\text { systems shall be designed, operated, closed, } \\
\text { and controlled after closure to provide } \\
\text { reasonable assurance that the annual EDEs to } \\
\text { individual members of the public beyond the } \\
\text { boundary of the disposal site will not exceed } \\
25 \text { mrem ( } 0.25 \mathrm{mSv}) \text { from all exposure } \\
\text { pathways." Determinations of reasonable } \\
\text { assurance shall be left to the judgement of the } \\
\text { PRP and other reviewers. }\end{array}$ \\
\hline $\begin{array}{l}\text { 2.3 Point of Compliance } \\
\text { 2.3.1 Where is the most exposed } \\
\text { individual located with respect to } \\
\text { the disposal site? }\end{array}$ & $\begin{array}{l}\text { There is no requirement on this in } \\
\text { DOE } 5820.2 \mathrm{~A} \text {. }\end{array}$ & $\begin{array}{l}\text { Outside the buffer zone, which shall be } \\
\text { defined in the site-specific PA but shall not } \\
\text { extend more than } 100 \mathrm{~m} \text { from any disposal } \\
\text { unit. However, during the period of active } \\
\text { institutional control over the disposal site, it } \\
\text { may be assumed, with proper justification } \\
\text { given in the PA, that control will be } \\
\text { maintained over a larger region. }{ }^{4}\end{array}$ \\
\hline $\begin{array}{l}\text { 2.4 Time of Compliance } \\
\text { 2.4.1 What is the time of } \\
\text { compliance (time certain or peak } \\
\text { dose)? }\end{array}$ & $\begin{array}{l}\text { There is no requirement on this in } \\
\text { DOE } 5820.2 \mathrm{~A} \text {. }\end{array}$ & $\begin{array}{l}\text { The PA shall identify the likely natural } \\
\text { processes and events that may affect the } \\
\text { disposal system, examine the effects of these } \\
\text { processes and events on the disposal system, } \\
\text { and estimate potential exposures for a period } \\
\text { of } 10,000 \text { yr. }\end{array}$ \\
\hline
\end{tabular}

The DOE steering committee for the revision of DOE 5820.2A has chosen 1,000 years, rather than 10,000 years, as the time of compliance. Neither recommendation is officially approved.

2.4.2 What assumptions are made about future land ownership/control?
Termination of monitoring and maintenance activity at closed facilities or sites shall be based on an analysis of site performance at the end of the institutional control period.

(DOE 5820.2A) 
Table D-1. (continued).

\begin{tabular}{|c|c|c|}
\hline Parameter & Requirement & Guidance $^{2}$ \\
\hline $\begin{array}{l}2.4 .3 \text { What institutional control } \\
\text { period is specified? }\end{array}$ & $\begin{array}{l}\text { The institutional control period is defined in } \\
\text { DOE } 5820.2 \mathrm{~A} \text { as, "A period of time, assumed } \\
\text { to be about } 100 \mathrm{yr} \text {, during which human } \\
\text { institutions continue to control waste } \\
\text { management activities." }\end{array}$ & $\begin{array}{l}\text { Active institutional controls include fences, } \\
\text { patrols, alarms, monitoring instruments, and } \\
\text { other activities requiring active attention, } \\
\text { enforcement, and interdiction. It is generally } \\
\text { agreed that the active institutional controls } \\
\text { should not be relied upon for more than } \\
100 \mathrm{yr} \text {. If protection beyond that time is } \\
\text { needed, passive controls (both institutional and } \\
\text { engineered features) may be provided. Passive } \\
\text { institutional controls may include land use } \\
\text { restrictions, government ownership, site } \\
\text { dedication to nonintrusive uses, and other } \\
\text { passive institutional means to limit access to } \\
\text { the waste. Passive controls also include } \\
\text { engineered features, such as long-lived } \\
\text { markers, engineered barriers, special waste } \\
\text { forms, burial depth, and special materials } \\
\text { incorporated into the site closure system. }\end{array}$ \\
\hline $\begin{array}{l}\text { 2.4.4 What assumptions are made } \\
\text { about active and passive controls } \\
\text { that may affect PA results? }\end{array}$ & None. & $\begin{array}{l}\text { Passive controls, including both engineered } \\
\text { features and institutional controls, (e.g., } \\
\text { physical barriers, markers, long-term } \\
\text { government ownership and control, and use } \\
\text { restrictions), may be incorporated into the } \\
\text { design to provide reasonable assurance that the } \\
\text { performance objectives will be met. The time } \\
\text { of effectiveness of passive controls must be } \\
\text { specified and justified in the PA.4 }\end{array}$ \\
\hline
\end{tabular}

\subsection{Dose Conversion}

2.5.1 What requirements or standards are used to determine dose conversion factors?
The doses calculated in the PA are evaluated per the requirements of DOE 5400.5 , Chapter II, Sections $6 b(2)(a)$ and (b). The internal conversion factors are based upon the ICRP reference man model, and the committed dose is the dose integrated over an interval of $50 \mathrm{yr}$. It should be noted that these sections of DOE 5400.5 reference the same documents that are referenced in the guidance.
The calculation of doses from the LLW facility should follow recommendations of the International Commission of Radiological Protection and should use dose conversion factors from DOE/EH-0070 and DOE/EH- $0071^{7}$ or those provided by the EPA in RFG- $11 .^{8}$ This guidance is from reference 3 . 
Table D-1. (continued).

\begin{tabular}{|c|c|c|}
\hline Parameter & Requirement & Guidance $^{\mathrm{a}}$ \\
\hline $\begin{array}{l}\text { 3. Receptor (inadvertent Intruder) } \\
\text { 3.1 Receptor Scenario } \\
\text { 3.1.1 What general assumptions } \\
\text { are required? }\end{array}$ & $\begin{array}{l}\text { There is no mention of intruder scenarios in } \\
\text { DOE 5820.2A. }\end{array}$ & $\begin{array}{l}\text { The PATT endorses the general types of } \\
\text { exposure scenarios that were developed by the } \\
\text { NRC and recommends that dose assessments } \\
\text { for inadvertent intruders consider the } \\
\text { following types of scenarios involving either } \\
\text { chronic exposures over a lifetime or a single, } \\
\text { acute exposure: } \\
\text { (1) An acute construction scenario and a } \\
\text { chronic agriculture (homesteader) scenario. } \\
\text { (2) An acute discovery scenario and a chronic } \\
\text { resident scenario. } \\
\text { (3) An acute drilling scenario and a chronic } \\
\text { post-drilling scenario. } \\
\text { However, the PATT does not recommend that } \\
\text { standard definitions of these scenarios be used } \\
\text { at all DOE disposal sites. Rather the PATT } \\
\text { recommends that the definition and application } \\
\text { of exposure scenarios for inadvertent intruders } \\
\text { be tailored to the particular characteristics of } \\
\text { the waste, disposal facility, and disposal site, } \\
\text { with adequate justifications provided in the } \\
\text { PA. }{ }^{4}\end{array}$ \\
\hline
\end{tabular}

3.1.2 What site-specific assumptions are used?

3.1.3 Are variations used to model against possible future environmental conditions?
Not applicable.

There is no mention of intruder scenarios in DOE 5820.2A.
The intruder scenarios must be appropriate for the environment of the site. Some examples of site-specific assumptions would be; the definition of exposure scenarios, the choice of exposure pathways and pathway models, and the selection of model parameter values. ${ }^{4}$

Each site PA should consider the effects of expected long-term changes to the degree that such changes may significantly impact the isolation capability of their disposal systems within the time period covered by the PA. Events and processes with small impact and probability should be omitted. Generally a qualitative discussion will suffice. ${ }^{4}$

To demonstrate compliance with the performance objectives, long-term calculations based on present conditions (including present rates of natural processes such as erosion) should be carried out. ${ }^{4}$ 
Table D-1. (continued).

\begin{tabular}{|c|c|c|}
\hline Parameter & Requirement & Guidance $^{3}$ \\
\hline $\begin{array}{l}\text { 3.2 Dose Standard } \\
\text { 3.2.1 What is the dose standard for } \\
\text { the most exposed hypothetical } \\
\text { inadvertent intruder? }\end{array}$ & $\begin{array}{l}\text { Assure that the committed EDEs received by } \\
\text { individuals who inadvertently may intrude into } \\
\text { the facility after the loss of active institutional } \\
\text { control ( } 100 \mathrm{yr} \text { ) will not exceed } 100 \mathrm{mrem} / \mathrm{yr} \\
\text { for continuous exposure or } 500 \mathrm{mrem} \text { for a } \\
\text { single acute exposure. (DOE } 5820.2 \mathrm{~A} \text { ) } \\
\text {. }\end{array}$ & $\begin{array}{l}\text { The PATT has debated two options for the } \\
\text { intruder dose objective in DOE } 5820.2 \mathrm{~A} \text {. The } \\
\text { Order states this as a performance objective, } \\
\text { parallel to the objective for protection of the } \\
\text { general public, requiring an analysis of } \\
\text { intrusion scenarios against the specified dose } \\
\text { objective. The alternative suggested is to use } \\
\text { an analysis of potential dose to a hypothetical } \\
\text { inadvertent intruder as the basis for setting } \\
\text { site-specific WAC, similar to the NRC } \\
\text { procedure for developing waste classes for } \\
10 \text { CFR } 61 . \text { The current direction of the } \\
\text { PATT opinion is toward using potential dose } \\
\text { to a hypothetical intruder as the basis for } \\
\text { setting site-specific WAC, but the issue } \\
\text { remains under discussion. }\end{array}$ \\
\hline $\begin{array}{l}\text { 3.3 Point of Compliance } \\
\text { 3.3.1 Where is the most exposed } \\
\text { individual located with respect to } \\
\text { the disposal site? }\end{array}$ & $\begin{array}{l}\text { Not covered as a requirement. The intruder } \\
\text { scenarios are site-specific. }\end{array}$ & $\begin{array}{l}\text { The intruder scenarios that are required to be } \\
\text { used generally assume that the individual is } \\
\text { located directly above the waste and has } \\
\text { brought some of the radionuclides to the } \\
\text { surface during their occupancy. }\end{array}$ \\
\hline $\begin{array}{l}\text { 3.4 Time of Compliance } \\
\text { 3.4.1 What is the time of } \\
\text { compliance (time certain or peak } \\
\text { dose)? }\end{array}$ & After 100 yr (DOE 5820.2A). & $\begin{array}{l}\text { The PA shall include the calculation of the } \\
\text { maximum projected impact to an inadvertent } \\
\text { intruder during the post-institutional control } \\
\text { period. The time period may last more than } \\
500 \mathrm{yr} \text {, depending on the time of maximum } \\
\text { impact. }^{\text {. }}\end{array}$ \\
\hline
\end{tabular}

3.4.2 What assumptions are made about future land ownership/control?

3.4.3 What institutional control period is specified?
Termination of monitoring and maintenance activity at closed facilities or sites shall be based on an analysis of site performance at the end of the institutional control period. (DOE 5820.2A)

The institutional control period is defined in DOE 5820.2A as, "A period of time, assumed to be about $100 \mathrm{yr}$, during which human institutions continue to control waste management activities."
Active institutional controls include fences, patrols, alarms, monitoring instruments, and other activities requiring active attention, enforcement, and interdiction. It is generally agreed that the active institutional controls should not be relied upon for more than $100 \mathrm{yr}$. If protection beyond that time is needed, passive controls (both institutional and engineered features) may be provided. Passive institutional controls may include land use restrictions, government ownership, site dedication to nonintrusive uses, and other passive institutional means to limit access to the waste. Passive controls also include engineered features, such as long-lived markers, engineered barriers, special waste forms, burial depth, and special materials incorporated into the site closure system. ${ }^{4}$ 
Table D-1. (continued).

\begin{tabular}{|c|c|c|}
\hline Parameter & Requirement & Guidance $^{3}$ \\
\hline $\begin{array}{l}\text { 3.4.4 What assumptions are made } \\
\text { about active and passive controls } \\
\text { that may affect } P A \text { results? }\end{array}$ & Not applicable. & $\begin{array}{l}\text { It is intended that disposal systems shall be } \\
\text { designed to provide reasonable assurance that } \\
\text { the potential dose to individuals who may } \\
\text { inadvertently intrude into the facility after the } \\
\text { active institutional control period (taken to be } \\
100 \text { yr after closure) will not exceed } 500 \text { mrem } \\
\text { for a single exposure or } 100 \text { mrem per yr for } \\
\text { exposure continuing over several years. } \\
\text { Passive controls, including both engineered } \\
\text { features and institutional controls, (e.g., } \\
\text { physical barriers, markers, long-term } \\
\text { government ownership and control, and use } \\
\text { restrictions), may be incorporated into the } \\
\text { design to provide reasonable assurance that the } \\
\text { performance objectives will be met. The time } \\
\text { of effectiveness of passive controls must be } \\
\text { specified and justified in the PA. }\end{array}$ \\
\hline $\begin{array}{l}\text { 3.5 Dose Conversion } \\
\text { 3.5.1 What requirements or } \\
\text { standards are used to determine } \\
\text { dose conversion factors? }\end{array}$ & $\begin{array}{l}\text { The doses calculated in the PA are evaluated } \\
\text { per the requirements of DOE } 5400.5 \text {, Chapter } \\
\mathrm{II} \text {, Sections } 6 \mathrm{~b}(2)(\mathrm{a}) \text { and (b). The internal } \\
\text { conversion factors are based upon the ICRP } \\
\text { reference man model, and the committed dose } \\
\text { is the dose integrated over an interval of } 50 \mathrm{yr} \text {. } \\
\text { It should be noted that these sections of } \\
\text { DOE } 5400.5 \text { reference the same documents that }\end{array}$ & $\begin{array}{l}\text { The calculation of doses from the LLW } \\
\text { facility should follow recommendations of the } \\
\text { International Commission of Radiological } \\
\text { Protection and should use dose conversion } \\
\text { factors from DOE/EH-0070 and } \\
\text { DOE/EH-0071 }{ }^{7} \text { or those provided by the EPA } \\
\text { in RFG- } 11 .^{8} \text { This guidance is from } \\
\text { reference } 3 \text {. }\end{array}$ \\
\hline
\end{tabular}

4. Release Mechanism 4.1 Waste Inventory 4.1.1 What are the requirements for keeping records on waste inventory?

4.1.2 How do current requirements for keeping records differ from past requirements?

4.1.3 Where past records are not up to today's standards, what is done to estimate waste inventory for purposes of the $P A$ ?
Requirements for keeping records on waste shipments for disposal prior to the issuance of DOE 5820.2A (September 26, 1988) are not available.

None. are referenced in the guidance references 6,7 , and 8.

Each field organization shall develop and maintain a record keeping system that contains information on the waste generated, treated, stored, shipped, or disposed of at its facilities. The information shall include all data necessary to show that the waste was properly classified, treated, stored, shipped, or disposed of. The data shall be based on the data recorded on waste manifests. Waste manifests will be kept as permanent records. (DOE 5820.2A) Requirements on retention and storage of the records are found in the DOE 1324 series of DOE Orders.
A shipment manifest or shipping paper must accompany each package of radioactive waste from a generator to a treatment, storage, or disposal facility. The manifest must include information on waste characteristics, including a physical description of the waste, the waste's volume and mass, each radionuclide's identity and quantity, total radioactivity, the principal chemical form, and the solidification agent (if any). As a minimum, the quantity of each of the radionuclides $\mathrm{H}-3, \mathrm{C}-14, \mathrm{Tc}-99$, and $\mathrm{I}-129$ must be listed. The manifest must also identify waste containing more than $0.1 \%$ by weight chelating agents, and an estimate of the weight percentage and identity of the chelating agent.9 Additional guidance on manifest reporting is given in Tab $M$ of reference 9.

No historical guidance on keeping records for waste disposal are known.

None. 
Table D-1. (continued).

\section{Parameter}

4.2 Source Term

4.2.1 What assumptions are made about the release mechanisms of radionuclides from the various

waste forms?

4.2.2 For purposes of the $P A$ during operations or for closure, is all waste included in the source term?
4.2.3 What is the source of scaling factors for indirectly measured radionuclides?
Requirement

Guidance $^{2}$

None.

DOE LLW that has not been disposed of prior to September 26, 1988 shall be managed to meet the performance objectives.

(DOE 5820.2A)

Note: A memorandum from J.E. Lytle, Deputy Assistant Secretary for Waste Management and Environmental Management, dated May 31, 1995 , states, "With the issuance of this memorandum, we are establishing a requirement that Operations Offices must include within the scope of performance assessments for active and planned LLW disposal facilities an analysis of other source terms that potentially add to the doses calculated for the receptor. Therefore, LLW disposed of prior to September 26, 1988, as well as other sources of radioactive contamination in the ground (e.g., spills, leaks, liquid discharge plumes), are to be included in performance assessments." The memorandum also states, "This directive is to remain in effect until the appropriate requirements are incorporated into a waste management order."

The concentration of radionuclides may be determined by indirect methods such as the use of scaling factors which relate the inferred concentration of one radionuclide to another that is measured if there is reasonable assurance that the indirect method can be correlated with actual methods.

(DOE 5820.2A)
The PA should describe the transport/pathway scenario under which radionuclides contribute to offsite doses to individuals. This scenario must identify the release mechanism. Examples of release mechanisms are: material leaching, ground surface contamination or runoff, and complex pathways that include combinations of these. A complex pathway may include biotic uptake of contaminants with subsequent intake by humans. ${ }^{3}$

The PA guidance does not differ from the DOE 5820.2A requirement.

Generators may establish an inferential measurement program whereby concentrations of radioisotopes that cannot be readily measured (through techniques such as gamma-spectroscopic analysis) are projected based on concentrations of radioisotopes that can be readily measured. An example would be the practice of scaling transuranic concentrations to concentrations of the isotope Ce-144. Scaling factors should be developed for facilities and waste streams on an individual basis, and should be initially determined and periodically confirmed through direct measurements. 
Table D-1. (continued).

\begin{tabular}{|c|c|c|}
\hline Parameter & Requirement & Guidance $^{2}$ \\
\hline $\begin{array}{l}\text { 5. Pathways } \\
\text { 5.1 Site Characteristics } \\
5.1 .1 \text { Must data about site } \\
\text { characteristics meet any quality } \\
\text { requirements in order to be used in } \\
\text { the } P A \text { ? }\end{array}$ & $\begin{array}{l}\text { Disposal site selection shall be based on an } \\
\text { evaluation of the prospective site in } \\
\text { conjunction with planned waste confinement } \\
\text { technology, and in accordance with the NEPA } \\
\text { process. (DOE 5820.2A) Consistent with } \\
\text { DOE 5700.6B, the LLW operational and } \\
\text { disposal practices shall be conducted in } \\
\text { accordance with applicable requirements of } \\
\text { ANSIASME NQA-1 and other appropriate } \\
\text { national consensus standards. (DOE 5820.2A) }\end{array}$ & $\begin{array}{l}\text { Because of the Quality Assurance (QA) } \\
\text { requirements, all aspects of the PA should be } \\
\text { conducted under a written Quality } \\
\text { Assurance/Quality Check (QA/QC) program. } \\
\text { However, use of earlier data obtained without } \\
\text { the guidance of a QA QC program is not } \\
\text { precluded. If such data are used, the effect of } \\
\text { the lack of QA/QC shall be discussed in the } \\
\text { analysis of uncertainty. Reference } 9 \text {, Tab L, } \\
\text { provides additional information and references } \\
\text { on QA. } \\
\text { The PA data base shall be documented in a } \\
\text { manner that will allow evaluation of data } \\
\text { representativeness, accuracy, precision, and } \\
\text { ranges of applicability. Data quality is } \\
\text { achieved when there is sufficient } \\
\text { documentation of the data to ensure } \\
\text { auditability and traceability. }\end{array}$ \\
\hline $\begin{array}{l}\text { 5.1.2 What requirements are there } \\
\text { to avoid the potential for } \\
\text { "masking" from nearby nuclear } \\
\text { facilities? }\end{array}$ & $\begin{array}{l}\text { Monitoring measurements to evaluate actual } \\
\text { and prospective performance should be made at } \\
\text { locations within and outside each facility and } \\
\text { disposal site. Monitoring should also be used } \\
\text { to validate or modify the models used in the } \\
\text { PA. (DOE 5820.2A) The monitoring program } \\
\text { shall be capable of detecting changing trends in } \\
\text { performance sufficiently in advance to allow } \\
\text { application of any necessary corrective action } \\
\text { prior to exceeding performance objectives. } \\
\text { The monitoring program shall be able to } \\
\text { ascertain whether or not effluents from each } \\
\text { treatment, storage, or disposal facility or } \\
\text { disposal site meet the requirements of } \\
\text { applicable EH Orders. (DOE 5820.2A) }\end{array}$ & $\begin{array}{l}\text { A monitoring program must provide for } \\
\text { identification of the origin and sources of } \\
\text { radioactive materials, chemically hazardous } \\
\text { substances, and chemical indicators of } \\
\text { migration in the environment. The monitoring } \\
\text { program must also identify reasons for any } \\
\text { change in concentrations of these materials.s }\end{array}$ \\
\hline $\begin{array}{l}5.2 \text { Waste Distribution } \\
5.2 .1 \text { What assumptions are made } \\
\text { about the distribution of waste in } \\
\text { disposal units for calculating dose } \\
\text { to the most exposed individual? }\end{array}$ & None. & $\begin{array}{l}\text { The waste is assumed to be uniformly } \\
\text { distributed. }{ }^{4}\end{array}$ \\
\hline $\begin{array}{l}5.2 .2 \text { What assumptions are made } \\
\text { about the distribution of waste in } \\
\text { disposal units for calculating dose } \\
\text { to a hypothetical inadvertent } \\
\text { intruder? }\end{array}$ & None. & $\begin{array}{l}\text { The waste is assumed to be uniformly } \\
\text { distributed. }{ }^{4}\end{array}$ \\
\hline
\end{tabular}


Table D-2. Non-DOE Performance Assessment Requirements and Guidance.

\begin{tabular}{|c|c|c|}
\hline Parameter & Requirement & Guidance \\
\hline $\begin{array}{l}\text { 1. General } \\
\text { 1.1 Format and content } \\
\text { 1.1.1 What is the general format? } \\
\text { What are the contents for the PA? }\end{array}$ & $\begin{array}{l}10 \text { CFR 61.10, et seq., specifies contents for } \\
\text { license applications. While the term, } \\
\text { "performance assessment" is not used, the } \\
\text { contents specify that an applicant show the } \\
\text { "pathways analyzed in demonstrating } \\
\text { protection of the general population from } \\
\text { releases of radioactivity," which include air, } \\
\text { soil, groundwater, surface water, plant uptake, } \\
\text { and exhumation by burrowing animals" } \\
\text { (61.13a). The applicant must also show that } \\
\text { there is reasonable assurance the waste } \\
\text { classification and segregation requirements will } \\
\text { be met and that adequate barriers to inadvertent }\end{array}$ & $\begin{array}{l}\text { Guidance on the expected format for a } \\
\text { disposal facility license application is provided } \\
\text { in the document, "Standard Format and } \\
\text { Content of a License Application for a } \\
\text { Low-Level Radioactive Waste Disposal } \\
\text { Facility," (NUREG-1199). The chapter of the } \\
\text { document on Safety Assessments outlines the } \\
\text { expected contents of a performance assessment } \\
\text { based on releases of radioactivity. This } \\
\text { includes determining the types of waste to be } \\
\text { disposed, avenues for radionuclide release, and } \\
\text { mechanisms for transfer of radionuclides to } \\
\text { humans. }\end{array}$ \\
\hline
\end{tabular}

1.2 Approval process

1.2.1 What is the formal process for final approval?

\section{1,3 Review process}

1.3.1 What formal review process does the PA go through before submittal for approval?

1.4 PA maintenance 1.4.1 Is $P A$ reviewed and updated as parameters change?

\subsection{Method for Evaluating}

\section{Uncertainty}

1.5.1 Deterministic or probabilistic? What kind of uncerlainty or sensitivity analysis, if any? intrusion will be provided (61.13b).

Before a commercially-operated disposal facility can operate, it must receive an operating license from the NRC or an Agreement State that meets NRC requirements through a period audit process. The same agency that licenses the facility regulates it on an ongoing basis. The performance assessment is approved as part of the application for a disposal license. The process for review and approval of a license application is described in 10 CFR Part 2, Subpart A.

None

10 CFR 61.80(i) requires that a disposal facility licensee report to the NRC (or agreement state agency) if radioactive releases or monitoring results "are significantly different from those expected in the materials previously reviewed as part of the licensing action."

None
The Standard Review Plan (NUREG-1200) provides guidance to NRC staff for reviewing applications for disposal facilities. Chapter 6, Safety Assessment, parallels the contents of the same chapter in the Standard Format and Content Guide, NUREG-1199. The assessment structure is divided into three parts: radioactivity release, transfer, and dose. NUREG-1274 provides information on the procedural aspects of the license application review process, but does not specifically address procedures for reviewing performance assessments.

None

A proposed NRC BTP on Performance Assessment, section D.5, recommends that licensees develop a "framework for determining the value and impact of ...new information on the calculation of concentrations and doses."

NUREG-1199 (Section 6.1.5.1.), a draft Branch Technical Position (BTP) on Performance Assessment dated January 1994, and other NRC guidance recommends that uncertainty and sensitivity analyses be conducted in order to determine that there is reasonable assurance that performance objectives will be met. The draft BTP recommends that an approach known as "probabilistic risk assessment" be used. Under this approach, the results of a number of separate computer runs using a wide range of values and assumptions are considered collectively. to establish a frequency distribution for the dose to an individual. 
Table D-2. (continued).

\begin{tabular}{|c|c|c|}
\hline Parameter & Requirement & Guidance \\
\hline $\begin{array}{l}\text { 1.6 Computer Codes } \\
1.6 .1 \text { Is there an approval process } \\
\text { for } P A \text { codes that is separate from } \\
\text { the } P A \text { approval process, itself? }\end{array}$ & $\begin{array}{l}\text { In the license application review process, the } \\
\text { code itself is not approved. Approval of a } \\
\text { license application implies that a code was } \\
\text { appropriate for the use intended. }\end{array}$ & $\begin{array}{l}\text { The NRC in the past has issued technical } \\
\text { reports that evaluate and recommend specific } \\
\text { computer codes for specific purposes. See } \\
\text { NUREG/CR-5453, v.5, "Computer Code } \\
\text { Implementation and Assessment." Until eariy } \\
\text { 1995, the NRC Low-Level Radioactive Waste } \\
\text { office conducted topical reports on a cost } \\
\text { recovery basis, at the request of individuals } \\
\text { and organizations. The final topical report, } \\
\text { before the NRC discontinued this program, } \\
\text { was evaluation and approval of the 3R-Stat } \\
\text { code for estimating concentrations of I-129 } \\
\text { and Tc-99 using scaling factors. }\end{array}$ \\
\hline
\end{tabular}

\author{
1.6.2 Does the code \\ approval/review process include \\ Validation? Verification?
}

None

NUREG 1199, in several places in Section 6, recommends that an applicant "describe and justify the type of model(s) used, the theoretical basis of each model." This should include "the procedures used to verify the codes and the methods for and results of model calibration...including model validation techniques and sensitivity analyses."

The draft BTP on PA, Section E.1., describes the recommended general scenario: The "maximally exposed individual" is assumed to reside at the site boundary, where offsite exposures to radionuclides released to air and water are expected to be greatest, and consumes locally grown food crops irrigated with contaminated ground-water withdrawn at the site boundary.

The draft BTP on PA advises that the basic scenario be tailored to meet conditions at a specific site. For example, the groundwater well should be located at a point along the site boundary that produces the maximum groundwater concentration.

The draft BTP on PA, Section D.1., states that "the uncertainty of future climate changes makes long-range projections on the scale of thousands of years impossible. To the extent that the natural and climatic history and geography of a site are known, there is a basis for projecting what the succession of vegetation at the site may be and for developing a reference biosphere for the PA model. Nevertheless, given the uncertainty in projecting timing and extent of climatic change, an approach for biosphere changes that bounds the current trends should be considered sufficient. The analyst may assume that the reference biosphere is present throughout the period of performance that is analyzed. 
Table D-2. (continued).

\section{Parameter}

2.2 Dose standard

2.2.1 What dose value to the individual is the standard?

\subsection{Point of compliance}

2.3.1 Where is the most exposed individual located with respect to the disposal site?
Requirement

10CFR61.41 requires that the dose received by any member of the public from all pathways not exceed an annual dose of $25 \mathrm{mrem}$ to the whole body, 75 mrem to the thyroid, and 25 mrem to any other organ.

10CFR61.52(a)(8) specifies that a "buffer zone of land must be maintained between any buried waste and the disposal site boundary and beneath the disposed waste.
2.4 Time of compliance

2.4.1 What is the time of compliance? (Time certain or peak dose?)
None

draft BTP on Performance Assessment, section D.3.3, states, however, that "a performance assessment analysis carried out to peak dose, even if it occurs over long timeframes, provides information about the relationships between the inventory of long-lived radionuclides (and daughters), the site characteristics (under current conditions) and the potential hazard to future generations for different scenarios." The BTP goes on to recommend that doses be calculated at the end of the passive institutional control period; at $10,000 \mathrm{yr}$, and to peak dose following 10,000 yr unless the applicant can demonstrate that the remaining inventory at the site would not result in the dose standard being exceeded. 
Table D-2. (continued).

\begin{tabular}{ll}
\hline \multicolumn{1}{c}{ Parameter } & \multicolumn{1}{c}{ Requirement } \\
\hline $\begin{array}{l}\text { 2.4.2 What assumptions are made } \\
\text { about future land } \\
\text { ownership/control? }\end{array}$ & $\begin{array}{l}\text { 10 CFR 61.14(b) requires that, "Where the } \\
\text { proposed disposai site is on land not owned by } \\
\text { the Federal or State government, the applicant } \\
\text { must submit evidence that arrangements have } \\
\text { been made for assumption of ownership in fee } \\
\text { by the Federal or State government.." At the } \\
\text { end of the prescribed period of institutional } \\
\text { control, the license will be terminated } \\
\text { (10 CFR 61.7(c)(4)). At that point, for } \\
\text { purposes of performance assessment, } \\
\text { institutional control is assumed to be lost. }\end{array}$
\end{tabular}

\subsubsection{What institutional control period is used?}

2.4.4 What assumptions are made about active and passive controls that may affect modeling?
10 CFR 61.59 requires that institutional controls not be relied upon (to avoid exposures to the maximally exposed individual) for more than $100 \mathrm{yr}$ following transfer of control of the disposal site to the owner (i.e., the 5-yr closure period).

During the 100-yr institutional control period, it is assumed that ongoing monitoring will be sufficient to identify and remediate conditions that would allow offsite releases in excess of the dose standard. [10 CFR 61.7 and 61.59(a)]
NUREG-1200, section 6.1, states "There is no fixed limit to the length of the institutional control period. However, for purposes of analysis of site performance, the institutional control period is separated into an "active" and a "passive" period. During the active period, which should normally be assumed to last no more than $100 \mathrm{yr}$, the above custodial activities may be assumed to be carried out by the site owner. The passive period follows the active period, and during this period it should be assumed that relatively few custodial activities are carried out."

Although institutional controls (such as the fence around the site boundary) may not be relied upon for more than $100 \mathrm{yr}$ following transfer of control of the disposal site to the state (10CFR 61.59(b)), an applicant may assume, for purposes of modeling, that the "most exposed individual" remains outside the institutional control area after $100 \mathrm{yr}$. (See point of compliance, above.)

NUREG-1199, section 6.1.2, states that a license applicant should provide and defend values for the infiltration rates through the disposal facility cover, which may be considered a passive control following the institutional control period.

External beta/gamma exposures due to proximity to uniformly contaminated surfaces, and beta/gamma exposures due to immersion in contaminated air may be based on the methodology presented in NUREG/CR-1918, or an equivalent methodology. Exposures to internal organs due to ingestion or inhalation pathways should be based on the methodology in International Commission on Radiological Protection, Publication 30, or its equivalent. (NUREG-1199, section 6.1.6) 
Table D-2. (continued).

\begin{tabular}{|c|c|}
\hline Parameter & Requirement \\
\hline $\begin{array}{l}\text { 3. Receptor (inadvertent intruder) } \\
\text { 3.1 Receptor scenario } \\
\text { 3.1.1 What are the general } \\
\text { (non-site-specific assumptions? }\end{array}$ & $\begin{array}{l}\text { The concentration limits in } 10 \text { CFR } 61.55 \text { for } \\
\text { LLW disposed in near-surface facilities were } \\
\text { set at levels that could be allowed in waste so } \\
\text { that the dose equivalent received by an intruder } \\
\text { would not exceed the } 500 \text {-mrem limit. For } \\
\text { Class A waste, the concentration limit was set } \\
\text { so the intruder would not receive the } 500 \text {-mrem } \\
\text { dose equivalent (whole body and bone; } 1,500 \\
\text { mrem for other organs) based on intruder- } \\
\text { agriculture or intruder construction scenarios at } \\
100 \text { years; the limits for Class B were based on } \\
\text { intruder-discovery scenarios at } 100 \text { years; and } \\
\text { the limits for Class C were based on intruder- } \\
\text { agriculture or intruder-construction scenarios at } \\
500 \text { years. All calculations were based on } \\
\text { uniform waste concentrations in the trench. } \\
\text { For Class C waste; it is assumed that disposal } \\
\text { at greater depth (at least } 5 \text { m) is sufficient to } \\
\text { isolate the waste from an inadvertent intruder. } \\
\text { Where site conditions prevent deeper disposal, } \\
\text { measures to prevent an intruder from coming } \\
\text { into contact with the waste for } 500 \text { yr must be } \\
\text { provided. Calculation of the } 500 \text { mrem } \\
\text { potential dose was done at } 500 \text { yr following } \\
\text { closure of the site, assuming that the intruder } \\
\text { barrier is no longer effective. (EIS for } \\
10 \text { CFR } 61, \text { NUREG } 0945 \text {, Nov. } 1982 \text {, Vol. } 1 \text {, } \\
\text { p.5- } 25 ; \text { also } 10 \text { CFR } 61.7 \text { (b)) }\end{array}$ \\
\hline
\end{tabular}

3.1.2 What site-specific
assumptions are used?

3.1.3 Are variations used to model against possible future environmental conditions?
"Analyses of the protection of individuals from inadvertent intrusion must include demonstration that there is reasonable assurance the waste classification and segregation requirements will be met and that adequate barriers to inadvertent intrusion will be provided." (10 CFR 61.13)

$$
\text { " }
$$

No. The waste classification system is designed to limit doses to inadvertent intruders under the range of environmental and other conditions considered in the preparation of the EIS for 10 CFR 61 .
Guidance

An applicant should provide information on intruder protection measures that would prevent an intruder from coming into contact with Class $C$ waste after the institutional control period. (NUREG-1199, section 6.2)

It is recommended that a license applicant provide information and analyses on the engineering features of the intruder protection system and on waste handling and segregation practices that will ensure that a potential inadvertent intruder will not come into contact with Class $\mathrm{C}$ waste during the 500-yr period of performance. Where the applicant relies on additional disposal depth to isolate the intruder from the waste, the applicant must provide engineering details on the type of material used as backfill and field controls used in its placement. (NUREG-1199, section 6.2) 
Table D-2. (continued).

\begin{tabular}{|c|c|c|}
\hline Parameter & Requirement & Guidance \\
\hline $\begin{array}{l}\text { 3.2 Dose standard } \\
\text { 3.2.1 What dose value to the } \\
\text { individual is the standard? }\end{array}$ & $\begin{array}{l}\text { The annual dose equivalent limit to the } \\
\text { inadvertent intruder is } 500 \text { mrem and was used } \\
\text { by the NRC to develop the classification limits } \\
\text { (see } 3.1 \text { ). This limit also includes a value of } \\
1500 \mathrm{mrem} / \mathrm{yr} \text { for organs other than bone. }\end{array}$ & $\begin{array}{l}\text { In setting the limits in the classification tables } \\
\text { and prescribing disposal practices for each } \\
\text { class of LLW, the NRC used a } 500 \text { mrem } \\
\text { annual dose limit to a person who } \\
\text { inadvertently intrudes into the Class A } \\
\text { disposal units after the } 100 \text {-yr active } \\
\text { institutional control period, or who intrudes } \\
\text { into a Class C disposal unit after } 500 \text { yr. The } \\
\text { dose equivalent limit also included a value of } \\
1500 \text { mrem/yr for organs other than bone. } \\
\text { (See Requirements for Receptor Scenario for } \\
\text { the inadivertent intruder, above.) }\end{array}$ \\
\hline
\end{tabular}

3.3 Point of compliance

3.3.1 Where is the most exposed individual located with respect to the disposal site?

\subsection{Time of compliance}

3.4.1 What is the time of compliance? (Time certain or peak dose?)

3.4.2 What assumptions are made about future land ownership and control?

\subsubsection{What institutional control period is used?}

3.4.4 What assumptions are made about active and passive controls that may affect modeling?

\subsection{Dose conversion}

3.5.1 What is the source of dose conversion factors? What assumptions are used?
At or over the disposal units.

(See Requirements for Receptor Scenario for the inadvertent intruder, above.)

(See Requirements for Receptor Scenario for

(Waste classification is based on exposure levels at $100 \mathrm{yr}$ for Class A LLW and $500 \mathrm{yr}$ for Class C LLW. See above.)

At the end of the prescribed period of institutional control, the license will be terminated (10 CFR 61.7(c)(4)). At that point, for purposes of performance assessment, institutional control is assumed to be lost.

"Institutional controls may not be relied upon (for protection of an inadvertent intruder) for more than $100 \mathrm{yr}$ following transfer of control of the disposal site to the owner (the state or federal government)" (10 CFR 61.59(b))

While passive controls, such as permanent trench markers, are required, they cannot be relied upon, for purposes of site evaluation, to deter an inadvertent intruder after the $100-y r$ active institutional control period. An applicant may demonstrate, however, that an engineer intruder barrier or additional depth to Class $C$ waste would deter a potential intruder (see Intruder Scenarios, above.)

The uuse conversion factors used by the NRC to calculate the LLW classification limits were from ICRP-2. the inadvertent intruder, above.)

Probably not applicable since the NRC used these dose conversion factors to calculate the LLW classification limits. Doses to an inadvertent intruder are not required to be calculated by a licence applicant. 
Table D-2. (continued).

\section{Parameter}

4. Release Mechanism

4,1 Waste inventory

4.1.1 How are records on waste inventory kept to ensure their integrity?

4.1.2 For currently operating sites, how does record keeping today differ from the past?

4.1.3 Where past records are not up to today's standards, what is done to estimate waste inventory, for purposes of $P A$ ?

\subsection{Source term}

4.2.1 What assumptions are made about the release of radionuclides from the various waste forms?
Requirement

10 CFR 61.80 specifies requirements for retention and periodic transfer of waste inventory records to the state or federal regulatory agency. The requirements for quality assurance under 10 CFR 61.12(j) specify that the QA program cover the operations period, as well as the construction and closure periods. Guidance on document control stem from these $Q A$ requirements.

None

.
4.2.2 For purposes of $P A$ during operations or for closure, is all waste included in the source term?
Three commercial disposal sites were operating under Agreement State licenses at the time 10 CFR 61 was issued in final. In the Federal Register Notice presenting the regulation (47 FR 57463), "the phasing in of the Part 61 requirements" was discussed. The discussion concluded that the following sections and subparts would be considered a matter of compatibility for the Agreement States: The Definitions, Performance Objectives, Technical Requirements, and certain other parts. Since the performance objectives (e.g., protection of the general population from doses exceeding 25-75-25) were evidently imposed retroactively on the already-operating sites, all waste disposed prior to issuance of the regulation apparently is to be considered in performance assessment.
Guidance

NUREG-1199, section 9.1.6, states that applicants should describe the measures established to control documents that prescribe activities affecting the quality of the design, construction and operation of a LLW facility. (This presumably includes records on the waste inventory disposed of in the disposal units.)

NUREG-1199, section 6.1.3, states that applicants should provide a "reasonable, but conservative, assessment of radioactivity release into each of the most significant radioactivity transport mechanisms..." While the document includes a table illustrating typical release scenarios, it indicates that these are only illustrative and states that applicants should provide an "analysis that identifies and quantifies the most significant scenarios based on the specific details of the site environment, the facility waste acceptance criteria, and the facility design and operating practices." 
Table D-2. (continued).

\begin{tabular}{|c|c|c|}
\hline Parameter & Requirement & Guidance \\
\hline $\begin{array}{l}\text { 4.2.3 What is the source of scaling } \\
\text { factors for indirectly measured } \\
\text { radionuclides? }\end{array}$ & $\begin{array}{l}10 \text { CFR } 61.55(a)(8) \text { specifies that "The } \\
\text { concentration of a radionuclide may be } \\
\text { determined by indirect methods such as the use } \\
\text { of scaling factors which relate the inferred } \\
\text { concentration of one radionuclide to another } \\
\text { that is measured..." }\end{array}$ & $\begin{array}{l}\text { NUREG-1199, section } 6.1 .1 \text {, states that } \\
\text { applicants should provide projections of the } \\
\text { physical, chemical and radiological } \\
\text { characteristics of each waste stream to be } \\
\text { disposed of at the proposed facility. This } \\
\text { information should include average } \\
\text { concentrations of the principal radionuclides } \\
\text { constituting the waste stream. }\end{array}$ \\
\hline $\begin{array}{l}\text { 5. Pathways } \\
5.1 \text { Site characteristics } \\
\text { 5.1.1 Must data about site } \\
\text { characteristics meet any quality } \\
\text { requirements or standards in order } \\
\text { to be used in } P A \text { ? }\end{array}$ & $\begin{array}{l}10 \text { CFR } 61.12(j) \text { requires applications for } \\
\text { disposal facility operating licenses to include } \\
\text { information on the their quality assurance } \\
\text { program for determining the natural disposal } \\
\text { characteristics of the proposed site. }\end{array}$ & $\begin{array}{l}\text { NUREG-1199; NUREG-1293, Quality } \\
\text { Assurance Guidance for Low-Level } \\
\text { Radioactive Waste Disposal Facility; and } \\
\text { DOE/LLW-150, Generic Quality Assurance } \\
\text { Plan, provide guidance on the framework for a } \\
\text { comprehensive QA program. }\end{array}$ \\
\hline $\begin{array}{l}\text { 5.1.2 What is done to avoid the } \\
\text { potential for "masking" from } \\
\text { nearby nuclear facilities? }\end{array}$ & $\begin{array}{l}10 \text { CFR } 61.50(11) \text { requires that, "The disposal } \\
\text { site must not be located where nearby facilities } \\
\text { or activities could adversely impact the ability } \\
\text { of the site to meet the performance objectives } \\
\text { of (this part) or significantly mask the } \\
\text { environmental monitoring program." } \\
61.53(a) \text { requires that, "At the time a license } \\
\text { application is submitted, the applicant shall } \\
\text { have conducted a preoperational monitoring } \\
\text { program to provide basic environmental data } \\
\text { on the disposal site characteristics...(c) The } \\
\text { monitoring system must be capable of } \\
\text { providing early warning of releases of } \\
\text { radionuclides from the disposal site before they } \\
\text { leave the site boundary. }\end{array}$ & \\
\hline $\begin{array}{l}5.2 \text { Waste distribution } \\
5.2 .1 \text { What assumptions are made } \\
\text { about the distribution of waste in } \\
\text { disposal units for calculating dose } \\
\text { to Most Exposed Individual? }\end{array}$ & None & None \\
\hline $\begin{array}{l}\text { 5.2.2 What assumptions are made } \\
\text { about the distribution of waste in } \\
\text { disposal units for calculating dose } \\
\text { to Inadvertent Intruder? }\end{array}$ & None & None \\
\hline
\end{tabular}


Table D-3. DOE Performance Assessment Practices for INEL (RWMC) and Hanford (200 West Area).

Parameter

INEL (RWMC)

Hanford (200 West Area)

1. General

1.1 Format and Content

1.1.1 What is the general format and contents of the $P A$ ?

1.2 Approval Process

1.2.1 What is the formal process for final approval of the PA?

\subsection{Review Process}

1.3.1 What formal review process does the PA go through before submittal for approval?

\subsection{PA Maintenance}

1.4.1 Does the PA need to be reviewed and updated if parameters change?

1.5 Method for Evaluating

Uncertainty

1.5.1 Is the method deterministic or probabilistic and what kind of uncertainty or sensitivity analysis is used?

\subsection{Computer Codes}

1.6.1 Is there an approval process for $P A$ codes that is separate from the $P A$ approval process?
The general format and content of the $\mathrm{PA}^{12}$ follows the recommendations in DOE $/ L L W-81^{2}$ very closely and also considers the guidance in DOE/LLW-62T.'

Not applicable

Not applicable

Not applicable

The $\mathrm{PA}^{12}$ includes a section that discusses needs for enhancement of data and environmental monitoring to improve the confidence in the assumptions and the results of the PA. Some of the needs are currently being or are planned to be addressed.

Typically, the models are deterministic, with a set of parameters used as input and producing a resulting output value. In reality input parameters are not single values; they exhibit stochastic variability. There is uncertainty in the input data used in a model; therefore, there is uncertainty in the output estimated by the model. Therefore, the method is probabilistic. A quantitative uncertainty analysis was performed using a variety of techniques, depending on the individual analysis. The techniques used were (1) assigning generic estimates of uncertainty to the results based on similar published analyses, (2) performing simple parameter perturbation analyses, or (3) performing Monte Carlo analyses.

Various techniques were also used to estimate sensitivity, such as (1) generic estimates using published sensitivity analyses, (2) simple perturbation analyses, or (3) correlation coefficients calculated from Monte Carlo analyses.

Not applicable
The format and content of the $\mathrm{PA}^{14}$ generally follows DOE LLW-81 ${ }^{2}$ with some minor modifications to Section 3, Analysis of Performance and Section 4, Results of Analysis.

Not applicable

The $\mathrm{PA}^{14}$ says very little about a PA maintenance program. However, it does state (page 5-4) that, as part of a PA maintenance program specified data should be collected and evaluated periodically to determine their effects on dose estimates.

The sensitivity analysis is approached deterministically by evaluating the change in the estimate as a function of systematic changes in the parameter value (page 4-7). Uncertainty in estimates are evaluated deterministically by considering likely ranges of values for parameters used in the required calculation (page 4-12). 
Table D-3. (continued).

\begin{tabular}{|c|c|c|}
\hline Parameter & INEL (RWMC) & Hanford (200 West Area) \\
\hline $\begin{array}{l}\text { 1.6.2 Does the code approval } \\
\text { process include validation and/or } \\
\text { verification? }\end{array}$ & $\begin{array}{l}\text { The INEL PA contains Appendix D which } \\
\text { contains a description of the computer codes } \\
\text { used in the Radioactive Waste Management } \\
\text { Complex (RWMC) PA. This description } \\
\text { includes information about verification and } \\
\text { validation of the codes. The codes used in the } \\
\text { RWMC PA are: MICROSHIELD 4, GENII, } \\
\text { GWSCREEN, PORFLOW, ORIGEN2, AND } \\
\text { RESRAD. }\end{array}$ & $\begin{array}{l}\text { Testing of the VAM3D-CG computer code, } \\
\text { Version } 2.4 b \text {, was conducted to establish } \\
\text { confidence that the code was ready for use in } \\
\text { performance assessment applications at the } \\
\text { Hanford site. Verification and benchmarking } \\
\text { were used to check the capabilities and } \\
\text { limitations of the code to simulate diverse } \\
\text { hydrological and geological conditions } \\
\text { pertinent to PA applications (see Appendix } \\
\text { G2). The primary method for completing dose } \\
\text { calculations was a set of hand calculations on a } \\
\text { spreadsheet. Radionuclide concentration } \\
\text { inventory limits were derived from these } \\
\text { calculations. The computer code GENII, } \\
\text { Version } 1.485 \text {, was used for benchmarking } \\
\text { purposes, to compare results and to ensure } \\
\text { accuracy of the spreadsheet formulas and } \\
\text { calculations. The spreadsheet formulas are } \\
\text { discussed in Appendix C of the PA (page 3-3). }\end{array}$ \\
\hline $\begin{array}{l}1.6 .3 \text { Is there a list of pre-approved } \\
\text { codes? }\end{array}$ & Not applicable & Not applicable \\
\hline 2. Receptor (most exposed & Not applicable & Not applicable \\
\hline
\end{tabular}

\section{individual}

2.1 Receptor Scenario

2.1.1 What general assumptions are required?

The INEL PA contains Appendix D which contains a description of the computer codes WSCREEN, PORFLOW, ORIGEN2, AND 
Table D-3. (continued).

\section{Parameter}

2.1.2 What site-specific assumptions are used?
Assumptions are made that the operational period of the RWMC will end in the yr 2020, the institutional control period will last for $100 \mathrm{yr}$ and during that period the facility will be closed, stabilized, and maintained but will still be fenced and patrolled and be part of the INEL reservation. Closure will consist of a thick soil barrier, which includes a vegetative cover that is placed over the operational cover. The total thickness of the cover at closure is $5 \mathrm{~m}$. During the post-institutional period, after yr 2120 , the facility is no longer maintained by the DOE and may be accessible to the public. During this time no maintenance is performed on the cover and erosion is assumed to occur down to the existing RWMC grade. At the time of maximum erosion, this results in $2.4 \mathrm{~m}$ of cover remaining over the waste in the pits and $3.3 \mathrm{~m}$ of cover remaining over the soil vaults.

It is assumed that during the operational and institutional control periods the soil contamination levels will not be higher than current levels. Since studies show that none of the existing burrowing animals at the INEL have been observed to burrow deep enough to penetrate the waste, it is assumed that harvester ants, which have been found in Wyoming and at the Hanford site, will appear at the INEL and burrow into the waste. It is also assumed that the deep roots of the big sagebrush penetrates the waste to bring radioactivity to the surface. The total activity brought to the surface through plant uptake is assumed to be dispersed into the environment and blown to a hypothetical receptor. This assumes that the entire big sagebrush aboveground biomass is converted to a dispersible form. There are also assumed scenarios for the most exposed member of the public and the hypothetical inadvertent intruder.
Hanford (200 West Area)

The PA evaluated disposal facilities for Category 1 and Category 3 waste. These wastes are similar, although not identical, in radionuclide content to the NRC defined Class $A$ and Class $C$ wastes. It is assumed that the Category 1 waste facility will be covered with a minimal thickness of cover of about $3 \mathrm{~m}$ and the Category 3 facility will be covered with a minimum thickness of $5 \mathrm{~m}$. The covers will be designed to limit or prevent erosion unless disturbed by man. Category 3 waste will be stabilized to support the soil cover overburden (page 2-35). The Category I facility is assumed to have a recharge rate (infiltration of rainwater into the soil column) of $5 \mathrm{~cm} / \mathrm{yr}$ and the Category 3 facility is assumed to have a recharge rate of $0.5 \mathrm{~cm} / \mathrm{yr}$ (page 3-17). 
Table D-3. (continued).

\begin{tabular}{|c|c|}
\hline Parameter & INEL (RWMC) \\
\hline $\begin{array}{l}\text { 2.1.3 Are variations used to model } \\
\text { against possible future } \\
\text { environmental conditions? }\end{array}$ & $\begin{array}{l}\text { The possibility of flooding occurring at the } \\
\text { RWMC is discussed and evaluated in the } \\
\text { Uncertainty and Sensitivity Analysis section of } \\
\text { the PA. Flooding is also mentioned as an area } \\
\text { where additional studies are needed. }\end{array}$ \\
\hline
\end{tabular}

\subsection{Dose Standard}

2.2.1 What is the dose standard (performance objective) for the most exposed individual?
The dose standards used for the RWMC PA are:

For the public, the annual dose is $\mathbf{2 5}$ mrem EDE per DOE 5820.2A.

For the inadvertent intruder the annual EDE for chronic exposure is $100 \mathrm{mrem}$ and the dose for an acute exposure is 500 mrem EDE per DOE 5820.2A.

For the public the annual dose from air emissions is 10 mrem EDE per 40 CFR 61 . For the pubic the annual dose from a community drinking water system is $<4$ mrem $\mathrm{EDE}$ and the drinking water gross alpha emitter concentration shall be less than 15 $\mathrm{pCi} / \mathrm{L}$ (in:suding Ra-226; excluding uranium and radon) and the radium-226 and -228 total concentration shall be less than $5 \mathrm{pCi} / \mathrm{L}$, per IDAPA 16.01.08000, and 40 CFR 141.
Hanford (200 West Area)

At the Hanford site, the meteorological conditions that require consideration are precipitation, flooding potential, high winds, and tornados. Of these the most important process relative to $\mathrm{PA}$ analyses is the assumption of recharge rates resulting from precipitation. A range of recharge rates is considered in the PA analysis as a function of assumed conditions (page 2-16). The processes of flooding, tomados, and high winds are not evaluated in the PA analysis. A short discussion of the reasons for not considering these conditions appears in Chapter 2 (page 2-17). The prevalent use of well water in the area for agricultural purposes (drinking and irrigation) requires that well drilling and water use for drinking and farming be considered as a primary means of exposure. The assumption of well drilling is used in the development of inadvertent intruder scenarios and all-pathways scenarios. The effects of large-scale commercial irrigation on site are also considered as a sensitivity case (page 2-19).

At the Hanford site, the U.S. DOE, Richland Operations Office has generated a supplemental Order, DOE-RLID 5820.2A that provides the following additional or clarifying performance objectives for the most exposed member of the public (page 1-5):

General Public Protection. Disposal systems shall be designed to ensure that exposure to any member of the public that results from disposal of solid LLW shall not exceed $25 \mathrm{mrem} / \mathrm{yr}$ EDE through all exposure pathways for at least $1,000 \mathrm{yr}$ after disposal. The point of compliance shall be no further from the edge of the waste than the Hanford site boundary during the period of active institutional control. After the active institutional control period (assumed to be not more than $100 \mathrm{yr}$ ), the point of compliance shall be not more than $100 \mathrm{~m}$ from the edge of the disposal site.

Groundwater Protection. Disposal systems shall be designed to ensure that disposal of LLW after September 26, 1988, does not result in concentrations of radionuclides (above existing levels) in groundwater exceeding those corresponding to an EDE of $4 \mathrm{mrem} / \mathrm{yr}$ to any person who might drink $2 \mathrm{~L} / \mathrm{d}$ of water from a well drilled into the aquifer, for at least $1,000 \mathrm{yr}$ after disposal. The point of compliance shall be no further than $100 \mathrm{~m}$ from the edge of the waste. 
Table D-3. (continued).

\begin{tabular}{ll}
\hline \multicolumn{1}{c}{ Parameter } & \multicolumn{1}{c}{ INEL (RWMC) } \\
\hline $\begin{array}{l}\text { 2.3 Point of Compliance } \\
\text { 2.3.1 Where is the most exposed }\end{array}$ & $\begin{array}{l}\text { During the operational and institutional control } \\
\text { period, the member of the public resided at the } \\
\text { the disposal site? }\end{array}$ \\
& INEL site boundary. During the \\
post-institutional control period, the member of \\
the public resided 100 m from the RWMC \\
SDA boundary. The intruder was assumed to \\
inadvertently intrude onto the RWMC SDA \\
during the post-institutional control period. \\
The intruder scenarios provide more details \\
about the way that the intruder picks up the \\
dose of radioactivity.
\end{tabular}

2.4 Time of Compliance

2.4.1 What is the time of compliance (time certain or peak dose)?

2.4.2 What assumptions are made about future land ownership/control?

\subsubsection{What institutional control period is specified?}

The operational period was assumed to last from 1984 to 2020, at which time the RWMC was assumed to be closed. The period of institutional control was assumed to last for $100 \mathrm{yr}, 2021$ through 2120, during which time maintenance and surveillance monitoring of the RWMC continued and no additional waste was received. During this time, the INEL site boundary was maintained, restricting public access to the RWMC. The post-institutional control period, beginning in the year 2120 , is the period during which no maintenance or surveillance monitoring occurred, and the area was available for unrestricted access and use by the public. The period has an indefinite ending point; analyses were made out to the point of maximum potential impact.

Because of the limitations of the land, it is not probable that a community would be established in the future at the RWMC. It is more likely that the area could be used for grazing livestock, such as cattle or sheep, and a well could be used for watering stock. The scenarios used in the PA calculations are unlikely cases.

The period of institutional control was assumed to last for $100 \mathrm{yr}, 2021$ through 2120 , during which time maintenance and surveillance monitoring of the RWMC continued and no additional waste was received. During this time, the INEL site boundary was maintained, restricting public access to the RWMC.
Hanford (200 West Area)

The point of compliance for protection of the general public shall be no further from the edge of the waste than the Hanford site boundary during the period of active institutional control. After the active institutional control period (assumed to be not more than $100 \mathrm{yr}$ ), the point of compliance shall be not more than $100 \mathrm{~m}$ from the edge of the disposal site. The point of compliance for groundwater protection shall be a well that is drilled no further than $100 \mathrm{~m}$ from the edge of the waste.

For the drinking water pathway, a minimum time of compliance of $1,000 \mathrm{yr}$ post closure has been specified in DOE-RL Order 5820.2A. As a design goal, the time of compliance has been extended to 10,000 yr for potential doses received from the drinking water, all-pathways, and Columbia river scenarios. The analyses generally show that the peak doses occur at times less than 10,000 yr (e.g., about 1,000 yr or less). In cases where peak doses occur after $10,000 \mathrm{yr}$, the results and their impacts are discussed (page 1-8).

It is assumed that a person could live, farm the land, drill a well, and raise livestock $100 \mathrm{~m}$ down gradient from the disposal facility after the end of the institutional control period (page 3-30).

The institutional control period is assumed to last for $100 \mathrm{yr}$ postclosure (page 1-8). 
Table D-3. (continued).

\begin{tabular}{|c|c|c|}
\hline Parameter & INEL (RWMC) & Hanford (200 West Area) \\
\hline $\begin{array}{l}\text { 2.4.4 What assumptions are made } \\
\text { about active and passive controls } \\
\text { that may affect } P A \text { results? }\end{array}$ & $\begin{array}{l}\text { Assumptions are made that the operational } \\
\text { period of the RWMC will end in the year } 2020 \text {, } \\
\text { the institutional control period will last for } \\
100 \text { yr and during that period the facility will } \\
\text { be closed, stabilized, and maintained but will } \\
\text { still be fenced and patrolled and be part of the } \\
\text { INEL reservation. Closure will consist of a } \\
\text { thick soil barrier, which includes a vegetative } \\
\text { cover that is placed over the operational cover. }\end{array}$ & $\begin{array}{l}\text { Category } 1 \text { waste is assumed to be covered by } \\
\text { a minimal thickness of cover (about } 3 \mathrm{~m} \text { ), thus } \\
\text { allowing the exhumation of waste by the } \\
\text { inadvertent intruder who digs a basement. The } \\
\text { category } 3 \text { waste is assumed to be covered by } \\
\text { a minimum } 5 \mathrm{~m} \text { cover. It is assumed that a } \\
\text { cover will be designed to limit or prevent } \\
\text { erosion unless disturbed by humans } \\
\text { (page 2-35). }\end{array}$ \\
\hline
\end{tabular}

\subsection{Dose Conversion}

2.5.1 What requirements or standards are used to determine dose conversion factors?
The total thickness of the cover at closure is $5 \mathrm{~m}$. During the post-institutional period, after year 2120 , the facility is no longer maintained by the DOE and may be accessible to the public. During this time no maintenance is performed on the cover and erosion is assumed to occur down to the existing RWMC grade. At the time of maximum erosion, this results in $2.4 \mathrm{~m}$ of cover remaining over the waste in the pits and $3.3 \mathrm{~m}$ of cover remaining over the soil vaults.

It is assumed that during the operational and institutional control periods the soil contamination levels will not be higher than current levels. Since studies show that none of the existing burrowing animals at the INEL have been observed to burrow deep enough to penetrate the waste, it is assumed that harvester ants, which have been found in Wyoming and at the Hanford site, will appear at the INEL and burrow into the waste. It is also assumed that the deep roots of the big sagebrush penetrates the waste to bring radioactivity to the surface. The total activity brought to the surface through plant uptake is assumed to be dispersed into the environment and blown to a hypothetical receptor. This assumes that the entire big sagebrush aboveground biomass is converted to a dispersible form. There are also assumed scenarios for the most exposed member of the public and the hypothetical inadvertent intruder.

The GENII computer code (version 1.485) was used to model the doses resulting from RWMC releases. Doses due to inhalation, ground surfaces, air immersion, and ingestion were calculated. The output from GENII is the EDE, which included the 50-yr committed EDE from internal exposure through the ingestion and inhalation pathways and the external EDE from ground deposition and air immersion. The dose conversion factors used in this analysis are from the GENII library that uses the most conservative dose conversion factors contained in DOE/EH $-0070^{6}$ and DOE/EH-0071.?
The dose calculations were done by hand calculations on a spreadsheet and compared to computer code calculations using GENII, Version 1.485 (page 3-3). The PA contains a comparison Table that lists dose conversion factors from the GENII computer code, EPA-520 (RFG-11, 1988), ${ }^{8}$ and DOE/EH-0071. ${ }^{7}$ The DOE dose conversion factors were actually used in the calculations (page C-15). 
Table D-3. (continued).

\begin{tabular}{|c|c|c|}
\hline Parameter & INEL (RWMC) & Hanford (200 West Area) \\
\hline $\begin{array}{l}\text { 3. Receptor (inadvertent Intruder) } \\
\frac{3.1 \text { Receptor Scenario }}{3.1 .1 \text { What general assumptions }} \\
\text { are required? }\end{array}$ & Not applicable & Not applicable \\
\hline $\begin{array}{l}\text { 3.1.2 What site-specific } \\
\text { assumptions are used? }\end{array}$ & $\begin{array}{l}\text { It is assumed that the intruder at the INEL } \\
\text { would have to use ground water because there } \\
\text { is no reliable source of surface water. The } \\
\text { acute intruder-construction scenario was not } \\
\text { evaluated for the soil vault rows because a } \\
\text { basement excavation would not contact the } \\
\text { waste. The contaminated drillings brought to } \\
\text { the surface by the intruder in the acute } \\
\text { intruder-drilling scenario are assumed to be } \\
\text { spread over the ground instead of in a mud pit } \\
\text { because that is the practice in the area. The } \\
\text { cuttings were assumed to be spread over a } \\
2,200 \mathrm{~m}^{2} \text { lot. It was assumed that the intruder } \\
\text { drills and develops a } 22 \text {-in. diameter irrigation } \\
\text { well and is exposed to the contaminated } \\
\text { cuttings for } 160 \mathrm{hr} \text {. Leaching of the }\end{array}$ & $\begin{array}{l}\text { The PA assumes that wastes that remain } \\
\text { hazardous to inadvertent intruders beyond } \\
100 \mathrm{yr} \text { (Category } 3 \text { waste) will have passive } \\
\text { controls, such as, long-term government } \\
\text { ownership and control, appropriate markers, } \\
\text { and barrier systems, incorporated to provide } \\
\text { reasonable assurance that inadvertent intruders } \\
\text { will be warned and deterred from disturbing } \\
\text { the site for up to } 500 \mathrm{yr} \text { (page 1-6). It is also } \\
\text { assumed that Category } 3 \text { waste is buried at } \\
\text { sufficient depth ( } 5 \mathrm{~m} \text { or more) to eliminate } \\
\text { excavation and root penetration as a feasible } \\
\text { means of exhuming waste (page 3-2). } \\
\text { Additional assumptions about the inadvertent } \\
\text { intruder scenarios appear on pages 3-5 and 3-6 } \\
\text { of the PA. }\end{array}$ \\
\hline
\end{tabular}

3.1.3 Are variations used to model against possible future environmental conditions?

\subsection{Dose Standard}

3.2.1 What is the dose standard for the most exposed hypothetical inadvertent intruder?

3.3 Point of Compliance

3.3.1 Where is the most exposed individual located with respect to the disposal site? radioactivity from the waste was not incorporated into the intruder dose assessments. This has little impact over relatively short time periods, however, it is an extremely conservative assumption over very long time periods.

The recommended intruder scenarios to use are specified and some site-specific modifications are permitted if justified, therefore, it is not

- appropriate to assume a different intruder scenario that might occur during or after some potential major change in environmental conditions. One could always find some scenario where the intruder performance objectives would be exceeded. That is not the purpose of the performance assessment.

The dose standards for the inadvertent intruder are the same as the requirements.

The intruder is assumed to inadvertently intrude onto the RWMC SDA during the post-institutional control period. Intruder scenarios provide more detail about how the intruder is exposed to radioactivity.
The dose standards for the inadvertent intruder are the same as the requirements.

For the intruder dose limits it is assumed that the intruder contacts the waste directly (page 1-7). The assumed acute exposure of the inadvertent intruder is during excavation of a home basement when waste is exhumed as part of construction, and when waste is exhumed while drilling a water well. The chronic exposure scenarios are post excavation and postdrilling, during which the exhumed waste is mixed with soil, spread around the site, and subsequently used to grow crops for consumption (page vii). 
Table D-3. (continued).

\begin{tabular}{|c|c|c|}
\hline Parameter & NNEL (RWMC) & Hanford (200 West Area) \\
\hline $\begin{array}{l}\text { 3.4 Time of Compliance } \\
\text { 3.4.1 What is the time of } \\
\text { compliance (time certain or peak } \\
\text { dose)? }\end{array}$ & $\begin{array}{l}\text { The intruder calculations begin after the } \\
\text { institutional control period ends, in the year } \\
2120 \text {. This period has an indefinite ending } \\
\text { point. Calculations were carried out to peak } \\
\text { dose. The maximum dose to a hypothetical } \\
\text { individual intruding into the pits occurred at } \\
\text { approximately } 1000,000 \text { yr. }\end{array}$ & $\begin{array}{l}\text { Inadvertent intrusion occurs in the Category } 1 \\
\text { waste at the end of the institutional control } \\
\text { period, } 100 \text { yr. However, because of passive } \\
\text { controls inadvertent intrusion occurs in } \\
\text { Category } 3 \text { waste at } 500 \mathrm{yr} \text { (pages viii and ix, } \\
\text { and } 1-8 \text { ). }\end{array}$ \\
\hline
\end{tabular}

3.4.2 What assumptions are made about future land ownership/control?

\subsubsection{What institutional control period is specified?}

3.4.4 What assumptions are made about active and passive controls that may affect $P A$ results?

3.5 Dose Conversion 3.5.1 What requirements or standards are used to determine dose conversion factors?
It is assumed that at the end of the institutional control period there will be no control over anyone living anywhere on the site. Nothing is specified about ownership of the land. Therefore, calculations of doses to the intruder are made using the prescribed intruder scenarios with some site-specific modifications.

The period of institutional control was assumed to last for $100 \mathrm{yr}, 2021$ through 2120 , during which time maintenance and surveillance monitoring of the RWMC continued and no additional waste was received. During this time, the $\mathrm{NEL}$ site boundary was maintained, restricting public access to the RWMC.

During the post-institutional period, after year 2120 , the facility is no longer maintained by the DOE and may be accessible to the public. During this time no maintenance is performed on the cover and erosion is assumed to occur down to the existing RWMC grade. At the time of maximum erosion, this results in $2.4 \mathrm{~m}$ of cover remaining over the waste in the pits and $3.3 \mathrm{~m}$ of cover remaining over the soil vaults.

The GENII computer code (version 1.485) was used to model the doses resulting from RWMC releases. Doses due to inhalation, ground surfaces, air immersion, and ingestion were calculated. The output from GENII is the EDE, which included the 50-yr committed EDE from internal exposure through the ingestion and inhalation pathways and the external EDE from ground deposition and air immersion. The dose conversion factors used in this analysis are from the GENII library that uses the most conservative dose conversion factors contained in DOE/EH- $0070^{6}$ and DOE/EH-0071?.
It is assumed that at the end of the institutional control period there will be no control over anyone living anywhere on the site. Nothing is specified about ownership of the land.

The institutional control period is assumed to last for $100 \mathrm{yr}$ postclosure (page 1-8).

Category 1 waste is assumed to be covered by a minimal thickness of cover (about $3 \mathrm{~m}$ ), thus allowing the exhumation of waste by the inadvertent intruder who digs a basement. The category 3 waste is assumed to be covered by a minimum $5 \mathrm{~m}$ cover. It is assumed that a cover will be designed to limit or prevent erosion unless disturbed by humans (page 2-35).

The dose calculations were done by hand calculations on a spreadsheet and compared to computer code calculations using GENII, Version 1.485 (page 3-3). The PA contains a comparison Table that lists dose conversion factors from the GENII computer code, EPA-520 (RFG-11, 1988) ${ }^{8}$, and DOE/EH-0071'. The DOE dose conversion factors were actually used in the calculations (page C-15). 
Table D-3. (continued).

\begin{tabular}{|c|c|c|}
\hline Parameter & INEL (RWMC) & Hanford (200 West Area) \\
\hline $\begin{array}{l}\text { 4. Release Mechanism } \\
4.1 \text { Waste Inventory } \\
4.1 .1 \text { What are the requirements } \\
\text { for keeping records on waste } \\
\text { inventory? }\end{array}$ & $\begin{array}{l}\text { For materials to be shipped to the INEL } \\
\text { receiving facilities, isotopes that are detected } \\
\text { with a true-positive indication are reported. } \\
\text { Isotopes below } 0.1 \mathrm{pCi} / \mathrm{g} \text { alpha and beta and } \\
\text { less than } 1.0 \mathrm{pCi} / \mathrm{g} \text { gamma are not required to } \\
\text { be reported. This reporting guidance is not to } \\
\text { be misconstrued as a definition of } \\
\text { non-radioactive or as unrestricted release } \\
\text { limits. }{ }^{12}\end{array}$ & $\begin{array}{l}\text { An annual report is prepared describing some } \\
\text { of the characteristics of LLW being disposed } \\
\text { at the Hanford site and projected to be } \\
\text { disposed during the next } 30 \text { yr. Most of the } \\
\text { information in this PA comes from the } \\
\text { information in the annual reports dated } 1992 \\
\text { and } 1993 \text {. The reports describe the physical } \\
\text { and chemical makeup of the waste and the } \\
\text { volumes of waste expected to be disposed at } \\
\text { the Hanford Site. The reports also discuss } \\
\text { uncertainties in the volume estimates and the } \\
\text { potential for additional sources of waste. } \\
\text { Radionuclide inventory data are not provided } \\
\text { in the annual report. Information on } \\
\text { radionuclide inventory is summarized from } \\
\text { responses to waste characterization } \\
\text { questionnaires provided by the individual } \\
\text { generators. Also, a computerized data base, } \\
\text { the Solid Waste Information and Tracking } \\
\text { System (SWITS), provides inventory and } \\
\text { waste volume data on a container-by-container } \\
\text { basis. These records are somewhat limited } \\
\text { because a complete listing of specific } \\
\text { radionuclides has not been required until the } \\
\text { last } 2 \text { yr (this probably means } 1992 \text { and } 1993 \\
\text { since the PA document is dated } 1994 \text { ). The } \\
\text { PA covers the waste buried from 1989 through } \\
1992 \text { and the projected waste to be buried } \\
\text { through the year } 2021 \text { (page } 2-20 \text { ). }\end{array}$ \\
\hline
\end{tabular}


Table D-3. (continued).

Parameter

4.1.2 How do current requirements for keeping records differ from past requirements?
INEL (RWMC)

Hanford (200 West Area)

For waste shipments prior to 1960 , there are no shipping records for the waste received from on the INEL. There are shipping records for waste received from the Rocky Flats Plant (RFP) in Colorado. Those records generally provide no quantitative information concerning the contaminants. The physical and chemical descriptions for the wastes disposed of between 1971 and 1986 do not provide insight into the actual contents of the waste (e.g., plant waste). The radionuclide information is very limited, such as: (a) entries with only one radionuclide identified, such as Pu-239, when knowledge of the waste generating process indicates that other radionuclides would also be present; (b) entries with only the element specified, e.g., uranium, with no designation of a particular radionuclide or mixture of radionuclides; entries with only generic radioactivity terms MAP or MFP identified, with no designation of particular radionuclides; and (d) entries with only one fission product or activation product identified, e.g., Cs- 137 or Co-60, when others should also be present. Prior to 1986 the data stored were only on a shipment basis. The activity or mass identified for a particular isotope was only identified for an entire shipment and not for individual containers. ${ }^{13}$
Before 1970, no distinction was made between TRU and LLW. In 1970, the AEC required that TRU waste be retrievably stored. Types of underground retrievable storage included shallow trenches, concrete lined "V" trenches, and asphalt pads. The segregated LLW continued to be disposed of. In the early 1980 s, low-level liquid organic waste was segregated from LLW and stored retrievably underground. A further categorization of LLW was made in 1987 when the concept of Mixed Waste (MW) was established. Mixed waste disposal was largely discontinued except on a case-by case basis where a significant reason for disposal could be justified. Storage on non-remote handled $\mathrm{MW}$ in above-ground buildings is the current practice (page 2-26). 
Table D-3. (continued).

Parameter

4.1.3 Where past records are not up to today's standards, what is done to estimate waste inventory for purposes of the $P A$ ?

INEL (RWMC)

Hanford (200 West Area)

The RWMC PA covers the period from 1984 through 2020. Unidentified activity accounts for only $0.12 \%$ of the activity disposed of in the pits and $0.033 \%$ of the activity disposed of in the soil vault rows. The activity is taken from the INEL data base RWMIS. Unidentified activity (denoted mixed activation products, mixed fission products, and unidentified beta-gamma) was assumed to be $50 \% \mathrm{Sr}-90$ and $50 \% \mathrm{Cs}-137$. The use of other radionuclides for unidentified activity was evaluated in the uncertainty analysis.
To address the intruder performance objectives a list of averaged radionuclide specific concentrations was determined using the four year record of radionuclide and generator specific waste disposed in the LLBG from 1989 through 1993 (Appendix B). A total projected inventory for the long-lived environmentally mobile radionúclides was estimated by extrapolating the 4-yr inventory to 30-yr (page 4-72).

Because some uncertainties severely restricted Hanford's ability to predict a finite LLW inventory, they used a unique approach to analyze the performance of the 200 West Area Burial Grounds. Unit concentrations or quantities of radionuclides were assumed, depending on the type of analysis. Groups of radionuclides were categorized into sets of different chemical properties. The analyses were then completed for a limited number of characteristic properties, such as, four different distribution coefficient $\left(K_{d}\right)$ values. The predicted dose under these conditions are then determined and compared with the appropriate performance objective dose limit. Because a unique dose corresponds to a unit concentration or quantity of a radionuclide if all other parameter are held constant, the concentration or quantity of a radionuclide can be calculated which corresponds to the dose limit.

This allows calculation of inventory limits for any set of radionuclides. Also, different sets of inventory limits can be calculated for a variety of combinations of environmental and disposal conditions, some of which provide greater isolation capability than others. Thus, a means of disposing of a range of waste inventory concentrations and/or quantities is provided (page 2-24 and 2-25). 
Table D-3. (continued).

\begin{tabular}{|c|c|}
\hline Parameter & INEL (RWMC) \\
\hline $\begin{array}{l}\text { 4.2 Source Term } \\
\text { 4.2.1 What assumptions are made } \\
\text { about the release of radionuclides } \\
\text { from the various waste forms? }\end{array}$ & $\begin{array}{l}\text { Release of radionuclides from activated metals } \\
\text { and waste containers were modeled. Release } \\
\text { from activated metals was by corrosion } \\
\text { leaching or by diffusion of tritium from } \\
\text { beryllium blocks. The average release rate } \\
\text { constant for corrosion release from activated } \\
\text { carbon or stainless steel was calculated to be } \\
4.17 \mathrm{E}-4 / \mathrm{yr} \text {. The release rate constant for } \\
\text { corrosion release of tritium from beryllium } \\
\text { blocks was calculated to be } 9.27 \mathrm{E}-4 / \mathrm{yr} \text {. } \\
\text { Corrosion release from the beryllium blocks } \\
\text { was determined to be the dominate release } \\
\text { mechanism for tritium. All tritium released } \\
\text { from the blocks was assumed to partition into } \\
\text { the soil pore water and migrate toward the } \\
\text { aquifer. }\end{array}$ \\
\hline
\end{tabular}

4.2 Source Term

4.2.1 What assumptions are made about the release of radionuclides from the various waste forms?
4.2.2 For purposes of the $P A$ during operations or for closure, is all waste included in the source term?
The release rate constant for waste contained in metal containers was estimated to be 0.1 per year and the release rate constant for waste in containers other than metal was assumed to be 0.5 per year. At an infiltration rate of $7 \mathrm{~cm} / \mathrm{yr}$ the result is a relatively instantaneous release of radionuclides from nonmetal containers following disposal. ${ }^{12}$

The RWMC PA covers the period from 1984 through 2020. The environmental restoration program at the INEL will assess waste buried in the SDA from 1952 through 1983 in accordance with the National Contingency Pian under CERCLA.
Hanford (200 West Area)

To introduce conservatism into the source term release estimates, the following assumptions were made: (1) It was assumed that containers were not present in the disposal facility and had no influence on the time at which waste would come in contact wi: infiltrating water. (2) For waste materials dis. used directly without treatment, it was assumed that the radionuclide inventory in those wastes was immediately available for release into the infiltrating water solution. (3) It is assumed that all infiltrating water receives the maximum amount of dissolved radionuclides prescribed by the release mechanism assumed in the modeling analysis. (4) For those wastes that are incorporated into a waste form that controls radionuclide release by diffusion or sorption or solubility mechanisms, such as grout, it is assumed in the models that the diffusion coefficient values remain constant over time.

In addition, the radionuclide inventories are assumed to be homogeneously distributed among the waste (page 3-11). An advection-dominated release model (mixing-cell cascade model) is used to simulate the processes of releases from unstabilized waste. A diffusion-dominated release model is used to simulate the release of contaminants from stabilized wastes. In addition to the diffusion-dominated release of the radionuclides from the burial trench, an alternative approach is to specify a solubility limit in the waste form (pages 3-12 to 3-15). For source term release, the mass transfer code VAM3D-CG is used to quantify the groundwater advective flux conditions and an. analytical solution, and the mixing-cell cascade model ${ }^{14}$ is used to calculate the radionuclide release from the waste material or waste form (page 3-8).

The total inventory for the 200 West Area LLBG was determine by using the LLBG inventory records for 1989 to 1992 and combining those with $30-y r$ volume forecasts provided by the generators (page XI). The PA analysis does not consider radiological releases from transuranic wastes or LLW disposed before September 1988. Wastes disposed before September 26, 1988 will be the focus of CERCLA remediation evaluations or RCRA closure (page 1-1). 
Table D-3. (continued).

\begin{tabular}{lll}
\hline \multicolumn{1}{c}{ Parameter } & \multicolumn{1}{c}{ INEL (RWMC) } & \multicolumn{1}{c}{ Hanford (200 West Area) } \\
\hline $\begin{array}{ll}\text { 4.2.3 What is the source of scaling } \\
\text { factors for indirectly measured }\end{array}$ & $\begin{array}{l}\text { To convert MAP and MFP to specific } \\
\text { radionuclides? }\end{array}$ & $\begin{array}{l}\text { There is no mention of use of scaling factors to } \\
\text { radionuclides, it was assumed that } \\
\text { would be representative of MFP and }\end{array}$ \\
& $\begin{array}{l}\text { radionuclides contained in fuel disassembly of the radionuclides in the } \\
\text { waste inventory. The Tables in Appendix B } \\
\text { appear to cover the difficult to analyze }\end{array}$ & $\begin{array}{l}\text { radionuclides such as C-14, Tc-99, and I-129. } \\
\text { radioned in spent nuclear fuel }\end{array}$
\end{tabular}

5. Pathways

5.1 Site Characteristics

5.1.1 Must data about sile characteristics meet any quality reguirements in order to be used in the $P A$ ?

\subsubsection{What requirements are there} to avoid the potential for "masking" from nearby nuclear facilities? radionuclides contained in fuel disassembly hardware and control rod elements would be representative of MAP. The specific radionuclides that were evaluated were derived from the Characteristics Data Base (CDB) developed by Oak Ridge National Laboratory in 1987..$^{15}$

The PA results are based on assumptions, simplifications, and scenarios that, in most cases, erred on the side of conservatism. Any uncertainties in the results due to a lack of a QA/QC program for data on site characteristics is expected to be minor compared to the assumptions, simplifications, etc. that were used.

The environmental monitoring program at the INEL is the primary mechanism to determine RWMC compliance with the applicable performance objectives. Results of the environmental monitoring program are -analyzed for potential problems so corrective actions to waste disposal methods at the RWMC can be taken if needed.

All soil vault inventory and pit inventory was assumed to be placed in a composite active disposal pit. The "composite" pit was assumed to have the combined dimensions of the pits used for disposal from 1984 through 1993 and forecast to be used for disposal from 1994 to 2020. All waste was assumed to be homogeneously mixed in the active pit volume. $^{12}$
There is no information in this PA about the quality requirements for the data on site characteristics.

In the area of the 200 West Area LLBG there are three other current or planned LLW disposal sites. The 200 East Area disposal site is east of the 200 West Area site. The U.S. Ecology site is located southwest of the 200 East Area site and the ERDF site is located west of the U.S. Ecology site. The groundwater flow is generally from west to east in this area. A two page discussion on the dose effects from the mixing of the contaminant plumes from these sites is given in the PA document (pages 4-60 through 4-63). The conclusion is that a relative increase in groundwater contamination due to the interaction of plumes from the 200 West Area Burial Grounds and other plumes on site is not expected.

Radionuclide inventories are assumed to be homogeneously distributed among the wastes (page 3-11). about the distribution of waste in disposal units for calculating dose to the most exposed individual? 
Table D-3. (continued).

Parameter

5.2.2 What assumptions are made about the distribution of waste in disposal units for calculating dose to a hypothetical inadvertent intruder?
INEL (RWMC)

Hanford (200 West Area)

The distribution of waste for calculating the dose to the hypothetical inadvertent intruder is the same as the distribution of waste for calculating dose to the most exposed individual (see paragraph PA.5.2.3.1 above).
In the inadvertent intruder scenarios the waste is extracted directly from the disposal facility. The exhumed waste is assumed to be indistinguishable from soil with the exception of activated metal. It was assumed that radionuciides entrained in activated metal are less likely to be dispersed into the environment even when exhumed and mixed with soil, thus reducing the potential dose from this source - relative to other waste materials (page 3-1). 
Table D-4. DOE Performance Assessment Practices for ORNL (SWSA 6) and Savannah River Site (E-Area Vaults).

\begin{tabular}{|c|c|}
\hline Parameter & ORNL (SWSA 6) \\
\hline $\begin{array}{l}\frac{1 . \text { General }}{1.1 \text { Format and Content }} \\
1.1 .1 \text { What is the general } \\
\text { format and contents of the } \\
P A \text { ? }\end{array}$ & $\begin{array}{l}\text { The } \mathrm{PA}^{16} \text { has been prepared in accordance with } \\
\text { the guidance provided by the DOE Peer Review } \\
\text { Panel that outlines the format and content for a } \\
\text { radiological performance assessment }{ }^{2} \text { (page } \mathrm{xxi} \text { ). }\end{array}$ \\
\hline $\begin{array}{l}1.2 \text { Approval Process } \\
1.2 .1 \text { What is the formal } \\
\text { process for final approval of } \\
\text { the PA? }\end{array}$ & Not applicable \\
\hline $\begin{array}{l}1.3 \text { Review Process } \\
1.3 .1 \text { What formal review } \\
\text { process does the PA go } \\
\text { through before submittal for } \\
\text { approval? }\end{array}$ & Not applicable \\
\hline $\begin{array}{l}\frac{1.4 \mathrm{PA} \text { Maintenance }}{1.4 .1 \text { Does the } P A \text { need to be }} \\
\text { reviewed and updated if } \\
\text { parameters change? }\end{array}$ & $\begin{array}{l}\text { Results of continued work on the } \mathrm{PA}^{16} \text { to address } \\
\text { several elements and the changes in operations } \\
\text { will be incorporated into a revision of the PA for } \\
\text { SWSA } 6 \text { (page } x x v \text { ). }\end{array}$ \\
\hline
\end{tabular}

1.5 Method for Evaluating

Uncertainty

1.5.1 Is the method deterministic or probabilistic and what kind of uncertainty or sensitivity analysis is used?
Deterministic and probabilistic methods were used to calculate the most probable, maximum, and minimum estimates of activity in wastes. The most probable or best estimates were used in the analysis and are presented with the $95 \%$ confidence level maximum and minimum activity values in Appendix A. The uncertainty in the inventory data in the analysis of environmental transport is addressed in Subsections of Section 4.6. The Latin Hypercube (LHC) sampling method was used to analyze the effects of.input variable uncertainties on the simulation models used in this study. LHC sampling ${ }^{17}$ has been shown to require fewer model iterations to approximate the desired variable distribution than the simple Monte Carlo method. PRISM ${ }^{18}$ was the program used to implement the LHC sampling technique for sensitivity and uncertainties analyses of the model predictions. A statistical summary of the model results produced indices of sensitivity and uncertainty that related the effects of heterogeneity of input variables to model predictions (page 4-69 to 4-70).
SRS (E-Area Vaults)

The format and content of the $\mathrm{PA}^{19}$ generally follow DOE/LLW-81, ${ }^{2}$ with some modifications to Sections 2, 3, and 4 .

Not applicable

Not applicable

The $\mathrm{PA}^{19}$ is to be maintained through time, and thus is a living document. Further iterations of the PA process will benefit greatly if opportunities are identified that will decrease the conservatism in the analysis. Reducing conservatism in the PA should enable disposal limits to be increased, thus enhancing the utility of the E-Area vaults. Opportunities to reduce the conservatisms are discussed on pages 5-3 and 54.

A rigorous quantitative analysis of uncertainty is desirable, but such an analysis is not possible for all aspects of the analyses conducted for the PA due to: (a) limits of our knowledge with respect to certain physical and functional characteristics or processes; (b) the ability to predict conditions in the future, especially beyond several decades; and (c) the inability to quantify uncertainty associated with the definition of a particular scenario. This last type of uncertainty can dominate the overall uncertainty in some cases (page 4-81). Further discussion of the sensitivity and uncertainty analysis is covered on pages 4-81 to 4-90. 
Table D-4. (continued).

\begin{tabular}{l} 
Parameter \\
\hline 1.6 Computer Codes \\
1.6 .1 Is there an approval \\
process for $P A$ codes that is \\
separate from the $P A$ \\
approval process?
\end{tabular}

1.6.2 Does the code approval process include validation and/or verification?

\subsubsection{Is there a list of pre- approved codes?}

\section{Receptor (most exposed} individual

2.1 Receptor Scenario 2.1.1 What general assumptions are required?
ORNL (SWSA 6)

SRS (E-Area Vaults)

Not applicable

Not applicable

Simulations of the release of radionuclides from disposal units and subsequent transport in water were carried out using the following six computer codes (page 3-33):

1. UTM - used to model the site water budget

(US DOE code center approved)

2. SOURCE1 - models the performance of the tumulus disposal technology

3. SOURCE2 - models the performance of disposal silos, wells, multiple containment wells, and biological trenches

4. WELSIM - simulates shallow subsurface transport and nuclide flux to groundwater from wells, silos, and trenches

5. TUMSIM - describes lateral subsurface nuclide transport through the stormflow zone and transport to groundwater through recharge from tumulus disposal units

6. USGS MOC - models solute transport and dispersion in a saturated porous medium (US DOE code center approved)

The status of the verification and validation of these codes is discussed on pages 3-38 through $3-41$. The verification and validation efforts at the time of the report were not complete, however, the authors feel that these codes have been verified and validated to a reasonable extent for use in the PA.

Not applicable

Not applicable
Appendix B of the PA contains a list of code selection criteria and considerations. One of the criteria that was an absolute requirement for selection of a code was, "The selected code(s) should be verified (i.e., simulation results compared against known analytical solutions of the underlying equations) to demonstrate correctness of the source code. Such verification should be fully documented in a technical report made available, at a minimum, to SRS and the Peer Review Panel."

Another criteria that was an absolute requirement for selection of a code was, "All simulation codes selected for use in the PA must be maintained under a software $Q A$ and management program that assures that modifications and updates are traceable, auditable and documented, and that all production versions have been verified and validated."

Other criteria that was desirable, but not required for selection of a computer code was, "The code(s) should be validated (e.g., simulation results compared with field data) for a system similar to that being modeled whenever possible. Benchmarking (i.e., code-to-code comparisons) is 'also useful in demonstrating code capabilities."

Not applicable

Not applicable 
Table D-4. (continued).

\begin{tabular}{|c|c|c|}
\hline Parameter & ORNL (SWSA 6) & SRS (E-Area Vaults) \\
\hline $\begin{array}{l}\text { 2.1.2 What site-specific } \\
\text { assumptions are used? }\end{array}$ & $\begin{array}{l}\text { There are a variety of disposal methods used for } \\
\text { LLW at SWSA } 6 \text {. Biological wastes were } \\
\text { disposed of in a trench and covered with at least } \\
3 \text { feet of dirt. When the trench was filled, the } \\
\text { surface of the closed trench was planted with } \\
\text { grass, mowed and kept free of trees. Biological } \\
\text { waste is no longer disposed if in the SWSA } 6 \\
\text { trenches. The current plan is to incinerate this } \\
\text { waste and store or dispose in a tumulus facility } \\
\text { (page 2-50). The remaining wastes disposed of } \\
\text { at SWSA } 6 \text { are closed with concrete covers. } \\
\text { Diffusion of contaminants through concrete is } \\
\text { assumed to be the primary mechanism of release } \\
\text { during the period of time that the concrete }\end{array}$ & $\begin{array}{l}\text { The E-Area Vaults (EAV) have been designed to } \\
\text { handle LLW that is classified as low-activity } \\
\text { waste (LAW), intermediate-activity waste (IAW) } \\
\text { and tritiated waste. IAW consists of material that } \\
\text { radiates greater than } 200 \mathrm{mR} / \mathrm{hr} \text { from an } \\
\text { unshielded container at } 5 \mathrm{~cm} \text {. LAW consists of } \\
\text { material that radiates less than } 200 \mathrm{mR} / \mathrm{hr} \text { from } \\
\text { an unshielded container at } 5 \mathrm{~cm} \text {. Tritiated waste } \\
\text { is waste that contains greater than } 10 \mathrm{Ci} \text { of } \\
\text { tritium per container regardless of the radiation } \\
\text { rate. The EAV will not dispose of or store liquid } \\
\text { wastes, waste containing greater than } 100 \mathrm{nCi} / \mathrm{g} \\
\text { of TRU isotopes, hazardous waste, or mixed } \\
\text { waste (page 1-4). }\end{array}$ \\
\hline
\end{tabular}

remains intact. Observations at ORNL over the last few decades suggest that emission of radionuclides directly to the atmosphere in gaseous form is not an important release mechanism at the site (page 3-10). Releases of radionuclides from the disposal units to surface water and groundwater are assumed to be the primary pathways for the transport of radionuclides to the environment (page 3-10). An off-site individual is assumed to be exposed to contaminated surface water released into the Clinch River from the present location of the White Oak Dam. The maximally exposed individual is assumed to use the contaminated water for domestic and recreational purposes (page 3-19). Closure scenario assumptions are covered on pages 3-16 to 3-19. The operational period is assumed to end in 1997 and the institutional control period is assumed to end in 2097. During the post-institutional control period the maximally exposed individual is assumed to be beyond the site boundary near the location of the White Oak Dam. It is assumed that White Oak Lake will be drained prior to loss of institutional control (page 3-20). The presence of concrete barriers in all disposal units except the biological trenches is assumed to preclude the agriculture scenario for 300 years after disposal because normal excavation procedures used in digging a foundation for a home cannot readily penetrate an intact concrete barrier. For disposal in unlined biological trenches, the agriculture scenario is assumed to occur after 100 years (pages 3-23 and 3-24). The construction and drilling scenarios were not included in the dose analysis for inadvertent intruders (page 3-25). The consumption rate of contaminated drinking water by exposed individuals was assumed to be $2 \mathrm{~L} /$ day and an exposure time for the discovery scenario was

Following are some assumptions used in this PA. This is not intended to be a complete list of assumptions, only a sample. The cover remains functional until the roof of the vault fails (page 36 and 3-57). The screening calculations assumed that the receptor consumes $2 \mathrm{~L} / \mathrm{d}$ of the pore fluid that would be present if the radionuclides were deposited directly in the groundwater (page 355). Contaminants escaping the vault cannot diffuse upwards through the cover. Advection dominates transport outside the vault (page 3-57). For the LAW vault, it is assumed that the containers have completely degraded and collapsed at the start of the simulation, yielding a large void above the waste (page 3-57). It is assumed that the flow around the intermediatelevel vault is at a steady state for the entire time that the vault is assumed to remain intact (page 361). Geochemical properties for the waste form are assumed to persist for the duration of the simulation (page 3-70).

Fractures occur at regular intervals as determined by the structural calculations; all fractures open simultaneously at a time specified; are assumed to be continuous and open, and filling or plugging by soils or precipitates is not considered; are saturated with water; and water drains freely at the base of the fracture (page 374). The recharge rate will remain constant during the future time period that is simulated; therefore, a steady-state flow will prevail (page 3-76). The compliance point is assumed to be the point of maximum concentration in groundwater, at least $100 \mathrm{~m}$ from the edge of the facility (page 4-17). It is assumed that offsite releases of volatile radionuclides (i.e., H-3 and C-14) can be neglected in the dose analysis beyond the buffer zone (page 4-28). It is assumed that the concrete is at a relatively low $\mathrm{pH}$ (at most 9.5) (page $\mathrm{K}$ 20). Since the EA Vault concrete has no calcium 
Table D-4. (continued).

Parameter ORNL (SWSA 6)

(2.1.2 continued)

2.1.3 Are variations used to model against possible future environmental conditions?

\subsection{Dose Standard}

2.2.1 What is the dose standard (performance objective) for the most exposed individual?

\subsection{Point of Compliance}

2.3.1 Where is the most exposed individual located with respect to the disposal site? assumed to be about 100 hours (page 4-40). More assumptions are discussed on pages 3-26 to 3-31 and on page 4-42.

There was no mention of possible long-term changes that may significantly impact the isolation capability of the disposal units at SWSA 6 that are covered in this PA. However, results of this PA shows that SWSA 6 does not presently meet the performance objectives of DOE $5820.2 \mathrm{~A}$.

The performance objectives that are used by the PA to demonstrate that LLW disposal methods meet the requirements of the US DOE are the same as those in DOE 5820.2A.
During the operational and institutional control periods an off-site individual is assumed to be exposed to contaminated surface water released into the Clinch River from the present location of White Oak Dam. The maximally exposed offsite individual is :ssumed to use contaminated witer released into the Clinch River from White Oak Creek for domestic and recreational purposes (page 3-19). During the postinstitutional control period the maximally exposed individuals are also assumed to exposed to contamination near the location of the White Oak Dam (page 3-20).
SRS (E-Area Vaults)

hydroxide available for leaching, the concrete strength is assumed to remain constant throughout the simulation (page $\mathrm{K}-24$ ).

Pos:-ible future environmental conditions that may aft $\therefore:$ degradation of the cover are: erosion, penetration by plants and animals; external events such as settling or slumping, or a seismic event; and human intrusion (page 3-5). Discussion of potential seismic events is found on pages 2-13 to 2-16. A detailed analysis of cover degradation is given in Appendix $\mathrm{K}$.

In addition to meeting the performance objectives in DOE 5820.2A, the PA for the EAV specifies the performance objective for protection of groundwater resources as, "Current EPA standards for radionuclides in drinking water, including the method prescribed by the EPA for calculating maximum contamination levels (MCLs) for beta/gamma-emitting radionuclides based on internal dosimetry data from ICRP Publication 2 (1959) and the specified MCLs for $\mathrm{H}-3$ and Sr-90." (page 1-10)

Compliance for radon will be assessed versus the radon exhalation rate that is stated as, "the limit for radon exhalation rate from the ground surface to air will be $20 \mathrm{pCi} / \mathrm{m}^{2} \mathrm{~s}\left(0.7 \mathrm{~Bq} / \mathrm{m}^{2} \mathrm{~s}\right)$." (Pages 111 and 1-12). Results from intrusion scenarios are presented to include doses from radon and its decay products; however, compliance is assessed by excluding the dose from radon and its decay products.

The point of compliance for groundwater protection requirements is taken to be that location more than $100 \mathrm{~m}$ from any disposed water at which the predicted concentrations of contaminants in groundwater are the highest. Requirements for protection of groundwater do not apply inside a $100-\mathrm{m}$ buffer zone around the disposal units (page 1-6). 
Table D-4. (continued).

Parameter

2.4 Time of Compliance

2.4.1 What is the time of compliance (time certain or peak dose)?

2.4.2 What assumptions are made about future land ownership/control?

\subsubsection{What institutional control period is specified?}

2.4.4 What assumptions are made about active and passive controls that may affect PA results?

ORNL (SWSA 6)

SRS (E-Area Vaults)

The analyses for every radionuclide that was considered in detail was carried out to the point of peak dose. Peak doses for uranium isotopes included the effects of buildup of decay products at extraordinary long times (page I-2).
After the loss of institutional control it is assumed that an inadvertent intruder can establish a permanent homestead directly above the waste. However, the maximally exposed individual that lived off-site during the institutional control period is still assumed to be located beyond the site boundary near the location of the White Oak . Dam during the post-institutional control period (page 3-20).

The institutional control period is assumed to last for 100 years post closure.

During the institutional control period the waste is covered by an "exposed geomembrane cover" for 30 years that is assumed to provide $99 \%$ hydrologic isolation for the disposal units. A multilayer CERCLA cap is assumed to be placed over the tumulus units, IWMF, and other disposal units 30 years post closure and it is expected to last for 70 years. A scenario of gradual deterioration of the CERCLA cap is described for the 70 year period. Concrete covers are assumed to remain intact for at least 300 years post closure so that an intruder can not excavate through the concrete to the waste for building a house. After the 100 years of institutional control is ended the site is assumed to revert to forest vegetation through species succession after the grass cover is no longer maintained (pages 3-16 through 3-21).

The internal dose conversion factors for ingestion and inhalation of radionuclides are from $\mathrm{DOE} / \mathrm{EH}-0071^{7}$ and the external dose conversion factors are from $D O E / E H-0070^{6}$. Tables containing the dose conversion factors used in this PA are shown and discussed in Appendix G (pages G-6 to G-12).
The performance objectives for protection of offsite members of the public, inadvertent intruders, and groundwater resources are applied for 10,000 years after disposal. If calculated doses to offsite members of the public or inadvertent intruders or calculated contaminant levels in groundwater do not attain their maximum values during the 10,000 -year compliance period, the calculations are continued in time until the peak values are obtained (page 17).

After the loss of institutional control, it is assumed that the maximally exposed offsite members of the public.can be located as close as $100 \mathrm{~m}$ from any of the EAV. However, an inadvertent intruder can establish a permanent homestead directly above the waste.

The institutional control period is the 100-year interval, specified in DOE 5820.2A, following closure of a disposal site (page 3-11).

The intermediate level (IL) vaults are adjacently located and are to be closed as one facility. The LAW vault facility will be closed separately. Closure of the vaults will be via below ground burial under about 8 feet of soil cover. The roof and walls of each vault type are expected to fail and collapse over time. This will result in infiltrating groundwater entering the interior of the vault rather than being diverted around its exterior (Appendix K, page 1). The waste in the IL vaults is to be grouted in place or enclosed in concrete until its failure (page 3-67).

A vault degradation study estimates that the IL faults will remain intact for 575 years, cracks will be forming from 575 years to 1050 years, and they will fail at 1050 years or later. The same study estimates that the LAW vaults will remain intact for 1400 years, cracks will be forming from 1400 years to 3100 years, and they will fail at 3100 years or later (page 3-73).

The internal dose conversion factors for ingestion and inhalation of radionuclides are from DOE/EH-0071. ${ }^{7}$ The external dose conversion factors with no shielding are from EPA 402-R-93$081^{20}$ and the extemal dose conversion factors through the engineered barriers (45- $\mathrm{cm}$ shielding for the LAW vaults and $100-\mathrm{cm}$ shielding for the IL vaults) are from Kocher and Sjoreen, $1985^{21}$ (Appendix A, pages A-39 to A-62). 
Table D-4. (continued).

\begin{tabular}{|c|c|}
\hline Parameter & ORNL (SWSA 6) \\
\hline $\begin{array}{l}\text { 3. Receptor (inadvertent } \\
\text { Intruder) } \\
\text { 3.1 Receptor Scenario } \\
\text { 3.1.1 What general } \\
\text { assumptions are required? }\end{array}$ & Not applicable \\
\hline $\begin{array}{l}\text { 3.1.2 What site-specific } \\
\text { assumptions are used? }\end{array}$ & $\begin{array}{l}\text { The parameter values used in the models for the } \\
\text { different exposure pathways were usually } \\
\text { intended to represent average conditions that } \\
\text { might be experienced by off-site individuals or } \\
\text { inadvertent intruders, as opposed to the } \\
\text { maximum possible conditions that would yield } \\
\text { the highest estimates of dose. Two exceptions to } \\
\text { this are (1) the assumed consumption rate of } \\
\text { contaminated drinking water by exposed } \\
\text { individuals of } 2 \text { L/day, and (2) the assumption of } \\
\text { an exposure time for the discovery scenario of } \\
\text { about } 100 \text { hours. Both of these assumptions } \\
\text { probably tend to overestimate exposure } \\
\text { conditions that would be experienced by average } \\
\text { individuals in critical population groups (page } 3- \\
\text { 10). } \\
\text { Observations at ORNL over the last few decades } \\
\text { suggest that emission of radionuclides directly to } \\
\text { the atmosphere in gaseous form is not an } \\
\text { important release mechanism at the site (page } 3- \\
\text { 10). Releases of radionuclides from the disposal } \\
\text { units to surface water and groundwater are } \\
\text { assumed to be the primary pathways for the } \\
\text { transport of radionuclides to the environment } \\
\text { (page } 3-10 \text { ). } \\
\text { The presence of concrete barriers in all disposal } \\
\text { units except the biological trenches is assumed to } \\
\text { preclude the agriculture scenario for } 300 \text { years } \\
\text { after disposal because normal excavation } \\
\text { procedures used in digging a foundation for a } \\
\text { home cannot readily penetrate an intact concrete } \\
\text { barrier. For disposal in unlined biological } \\
\text { trenches, the agriculture scenario is assumed to } \\
\text { occur after } 100 \text { years (pages } 3-23 \text { and } 3-24 \text { ). The } \\
\text { construction and drilling scenarios were not } \\
\text { included in the dose analysis for inadvertent } \\
\text { intruders (page } 3-25 \text { ). }\end{array}$ \\
\hline
\end{tabular}

3.1.3 Are variations used to model against possible future environmental conditions?

\subsection{Dose Standard}

3.2.1 What is the dose standard for the most exposed hypothetical inadvertent intruder?
See the comment from Table D-3 on this same question.

The dose standards for the inadvertent intruder are the same as the requirements.
Acute exposure scenarios for inadvertent intruders were not included because they would always be less restrictive in regard to demonstrating compliance with performance objectives than chronic exposure scenarios. Four chronic exposure scenarios were evaluated. A study showed that the vaults will be effective intruder barriers for at least 1,000 years. Doses from buildup of radium and radon daughters from U238 and U-234 exceed performance objectives at very long times $(200,000$ to $2,000,000$ years) after disposal. However, this PA assumes that only doses calculated out 10,000 years after disposal are considered for compliance. Also doses from radon and its decay products are excluded from inadvertent intruder dose for the purpose of assessing compliance (page 4092). A separate performance objective for radon $\left(20 \mathrm{pCi} / \mathrm{m}^{2} \mathrm{~s}\right)$ was established. A conservative analysis for radon flux at 10,000 years showed that it met that performance objective (pages A-34 to A-36).

The dose standards for the inadvertent intruder are the same as the requirements except the intruder dose does not include the dose from radon in the evaluation of compliance. 
Table D-4. (continued).

Parameter

3.3 Point of Compliance

3.3.1 Where is the most exposed individual located with respect to the disposal site?

\subsection{Time of Compliance} 3.4.1 What is the time of compliance (time certain or peak dose)?

3.4.2 What assumptions are made about future land ownership/control?

\subsubsection{What institutional control period is specified?}

3.4.4 What assumptions are made about active and passive controls that may affect $P A$ results?

ORNL (SWSA 6$)$

SRS (E-Area Vaults)

The following four scenarios are assumed in the - dose analysis for inadvertent intruders into the different disposal units at SWSA 6: an agriculture scenario involving direct intrusion into disposal units by excavation at anytime beyond 300 years after disposal for units constructed with engineered barriers and at anytime beyond 100 years after disposal for the biological trenches; a resident scenario involving exposure during residence in a home on top of intact engineered barriers above disposal units at 100 years after disposal (except for the biological trenches); a discovery scenario involving exposure while excavating at a disposal site in the presence of intact engineered barriers at 100 years after disposal for all disposal units except for the biological trenches (this is only applied to disposal units where the thickness of the engineered barriers at the sides of the units is considerably less than the thickness at the top of the units); a post-drilling scenario involving direct intrusion into disposal units by drilling at 100 years after disposal for all disposal units (page 3-24 and 3-25).

The calculations are carried out to the point of peak dose for every radionuclide that was considered in detail Appendix I, page I-2).

After the loss of institutional control it is assumed that an inadvertent intruder can establish a permanent homestead directly above the waste (page 3-20).

The institutional control period is assumed to last for 100 years post closure.

Concrete covers are assumed to remain intact for at least $\mathbf{3 0 0}$ years post closure so that an intruder can not excavate through the concrete to the waste for building a house. After the 100 years of institutional control is ended the site is assumed to revert to forest vegetation through species succession after the grass cover is no longer maintained (pages 3-16 through 3-21)
The intruder scenarios all assume that the intruder is located directly above the waste and in some scenarios is able to make direct contact with the waste.
The performance objective is assumed to apply for 10,000 years after disposal (page 3-39). Calculations on some daughter products of longlived radionuclides were carried out for very long periods of time; however, they were not used to determine compliance with the performance objectives.

After the loss of institutional control, it is assumed that the maximally exposed offsite members of the public can be located as close as $100 \mathrm{~m}$ from any of the EAV. However, an inadvertent intruder can establish a permanent homestead directly above the waste.

The institutional control period is the 100-year interval specified in DOE 5820.2A following closure of a disposal site (page 3-11).

A vault degradation study estimates that the IL vaults will remain intact for 575 years, cracks will be forming from 575 years to 1050 years, and they will fail at 1050 years or later. The same study estimates that the LAW vaults will remain intact for 1400 years, cracks will be forming from 1400 years to 3100 years, and they will fail at 3100 years or later (page 3-73). It is assumed that the vaults will be effective intruder barriers for at least 1,000 years (page 4-92). 
Table D-4. (continued).

Parameter

ORNL (SWSA 6)

SRS (E-Area Vaults)

3.5 Dose Conversion

3.5.1 What requirements or standards are used to determine dose conversion factors?

4. Release Mechanism 4.1 Waste Inventory 4.1.1 What are the requirements for keeping records on waste inventory?
The internal dose conversion factors for ingestion and inhalation of radionuclides are from DOE/EH-0071 ${ }^{7}$ and the external dose conversion factors are from DOE/EH-00706. Tables containing the dose conversion factors used in this PA are shown and discussed in Appendix G (pages G-6 to G-12).

Waste generators complete standard forms for each waste package that they generate. In completing these forms they (1) determine the activity of the package by estimation, calculation (6CEn), assay, etc.; (2) state the physical form of the packets within the package, such as 5-gal metal cans, small plastic bags, etc.; (3) state the instrument used to perform the survey, such as a portable ion chamber or in-cell probe; (4) state the dose rate measured for the packets within the package; (5) state the distance from the instrument to the packet; and (6) state the assumptions concerning the packet contents, such as the nuclides in the packets (page A-41).
The internal dose conversion factors for ingestion and inhalation of radionuclides are from DOE/EH-0071. ${ }^{7}$ The extemal dose conversion factors with no shielding are from EPA 402-R-93$081^{20}$ and the external dose conversion factors through the engineered barriers ( $45-\mathrm{cm}$ shielding for the LAW vaults and $100-\mathrm{cm}$ shielding for the IL vaults) are from Kocher and Sjoreen, $1985^{21}$ (Appendix A pages A-39 to A-62).

The E-Area Vaults are a new LLW disposal facility located at the SRS. Since it is a new facility, this PA does not mention anything about keeping records on the waste inventory. 
Table D-4. (continued).

Parameter ORNL (SWSA 6)

SRS (E-Area Vaults)

4.1.2 How do current reguirements for keeping records differ from past requirements?
For most facilities, operations personnel inferred the listed isotopes based upon their knowledge of the facility operation or the material being processed. In general, it cannot be said with certainty that any specific package contained the specific radionuclide(s) reported. It also cannot be stated that a package did not contain additional radionuclides other than those reported. On rare occasions, the waste was sampled and appropriate analyses were performed to specifically identify the radionuclides present. The identification of the principal isotope was straightforward for certain facilities that handled only specific isotopes and where the waste represented process waste. For many facilities, however, the waste form was contaminated components or irradiated materials that probably contained several different radionuclides. In these cases, the principal isotope identified in each waste package was the isotope or isotopes that were considered by the generator to be the most significant. The significance was typically based on an isotope's activity and radiological half-life. For example, irradiated metal waste, such as stainless-steel cladding hulls, contained a variety of activation products shortiy after irradiation; but $\mathrm{Co}^{60}$ was reported as the only principal isotope because it was the most significant in terms of activity, half-life, and radiation energy. In other facilities the principal isotopes were listed as $\mathrm{Cs}^{137}$ and $\mathrm{Sr}^{\circ}$. Operations personnel based this listing on the general operating history of the facility. Even though source production processes were operating in different hot cells, all packages of waste from the facility were considered to be composed of equal activities of $\mathrm{Cs}^{137}$ and $\mathrm{S}^{30}$ (page A-18). Additional information on the problems encountered in the determination of the quantity of the principal isotope are discussed on pages $A-21$ to $A-26$.
Not applicable since this is a new facility. 
Table D-4. (continued).

Parameter

4.1.3 Where past records are not up to today's standards, what is done to estimate waste inventory for purposes of the $P A$ ?

\subsection{Source Term}

4.2.1 What assumptions are made about the release of radionuclides from the various waste forms?

ORNL (SWSA 6)

SRS (E-Area Vaults)

For each radionuclide of interest in each disposal uri:: the general methodology used to determine the total most probable activity and associated uncertainty involved a two-phased approach. The first phase consisted of evaluating the source inventory of each disposal unit and selecting records for a sufficient number of waste packages to comprise a relatively large percentage of the total activity for each radionuclide of interest. Interviews with waste generators and evaluation of data sheets for these significant packages were conducted. Based on the information gathered, the activity probability distribution was calculated and the most probable activity and associated minimum and maximum activity (at the $95 \%$ confidence interval) were determined for each radionuclide of interest in these significant packages.

The second phase to the approach accounted for the remaining activity. The methodology used in the most probable activity calculation for the remaining activity was, in some cases, different than that used in the calculation for the significant packages. Once the proper method was selected, the assignment of uncertainties used to determine the minimum and maximum activity was identical to those used for the selected packages in phase one.

The total activity for each radionuclide in the disposal unit is given by the sum of the most probable activities for the significant packages and the remaining activity. A similar summation gives the minimum and maximum activity for each radionuclide in each disposal unit (pages $A$ 41 to $A-43$ ).

Leachate generated after water reaches the waste in the disposal units may be released through leaks in containment and by advection and diffusion through the concrete in the disposal units. In this PA, diffusion of contaminants through concrete is assumed to be the primary mechanism of release during the period of time that the concrete remains intact. When the concrete degrades and cracks are assumed to form, advection becomes the primary mechanism for release of radionuclides (page 3-10). Release of radionuclides from the above-ground (tumulus) disposal units is assumed to occur primarily to surface water or to the soil surface. Radionuclides released from the below-ground silos and wells are assumed to enter soils and groundwater. Releases of radionuclides from the biological trenches also occur mostly to groundwater and soils (page 3-13).
Not applicable

The waste is considered $:-$ he immobile until it contacts water. The entr:: inventory of the vault is assumed to be available to react with the water inside the vault. The aqueous concentrations of radionuclides are controlled by sorption onto corrosion products or grout with a solubility limited upper concentration. Contaminated water exiting the vault will interact with the concrete vault, and radionuclides will be chemically retarded by the vault wall (page 3-4). The release of radionuclides from the vaults depends on the vault aqueous chemistry, solubility, and sorption behavior of the relevant radionuclides. The chemical conditions in the vaults are controlled by the dissolution of the soluble constituents of the cement and by the corrosion of the iron waste containers and activated metals. As this corrosion takes place, slow changes will occur in the vault chemical conditions (page D-30). 
Table D-4. (continued).

Parameter

4.2.2 For purposes of the $P A$ during operations or for closure, is all waste included in the source term?
ORNL (SWSA 6)

The PA considers waste disposed of from September 26, 1988 to December 31, 1997, for estimating waste inventories over the projected period of facility operation (page A-17).
4.2.3 What is the source of scaling factors for indirectly measured radionuclides?
The ORNL identified the key radionuclides that were disposed of at each disposal facility. The list of key radionuclides was expanded further to include any radionuclide that represented $>0.1 \%$ of the concentration limit developed in the draft PA dated September 1990. Radiation survey data were obtained for each waste package. The survey dose rate was converted to curies using a standard ORNL conversion factor. The distribution of the activity for each key radionuclide was determined by the generator and is not described in the PA. This method has some uncertainties based on the radionuclides involved and the geometry and shielding involved in the measurement. Evaluations of the activity determinations were done and calculations determined the uncertainties associated with the data (pages A-18 to A-26).
SRS (E-Area Vaults)

Since this is a new facility that has not been operational, this question does not apply. This PA was prepared using reasonable, but conservative, parameter values to calculate disposal facility inventories that will meet the performance objectives. Implementation of these limits as waste acceptance criteria and waste certification program will provide reasonable assurance that the performance objectives will be met (page 5-2). The operational period for these facilities is expected to be at least 20 years (page 3-10). This PA assumed that 100 acres would provide disposal capacity for these 20 years of operation. These 100 acres would include 20 IL vaults and 21 LAW vaults (page 249). Assuming adequate funding is maintained at the SRS, these facilities are projected to be in operation by the year 2000 (page 1-3).

Not applicable 
Table D-4. (continued).

Parameter

\section{Pathways}

5.1 Site Characteristics

5.1.1 Must data about site characteristics meet any quality requirements in order to be used in the $P A$ ?
5.1.2 What requirements are there to avoid the potential for "masking" from nearby nuclear facilities?

\subsection{Waste Distribution}

5.2.1 What assumptions are made about the distribution of waste in disposal units for calculating dose to the most exposed individual?

ORNL (SWSA 6)

SRS (E-Area Vaults)

There is no information in this PA about the quality requirements for the data on site characteristics. Each stage in the modeling uses simplifying assumptions involving inexact parameters and variables. The influence of the uncertainty in model parameters on the predicted contaminant concentrations is typically estimated by means of a parameter variance study. Such a study was carried out by Latin Hypercube (LHC) sampling of the parameters, whose variability is assumed to be represented by appropriate probability distributions. The uncertainty in the model parameters associated with each stage contributes to an overall uncertainty in the final projected contaminant concentration and dose (page $\mathrm{H}-1$ ).

It is recognized that the model is not likely to produce a computed concentration without errors. The uncertainty associated with asserting that the actual contaminant concentration is in compliance is assumed to come from two basic sources: (1) given that the model is an accurate representation of the transport process, the physical parameters are never known exactly; (2) the composite model may be flawed in the sense that it is not sufficiently specific to adequately describe the site and its details and, at the same time, is not sufficiently robust to describe the site for tens $0:$ 'housands of years (page $\mathrm{H}-2$ ).

No discussion was found in the PA on potential masking of SWSA 6 contamination by contamination from nearby nuclear facilities.

Each disposal unit was assumed to be a uniform composition (i.e., homogeneously heterogeneous in an engineering sense). The waste was taken to have an average open-pore void fraction of 0.27 , and the concrete, of 0.15 (page 3-31).
Contributors to this PA conducted pertinent activities of the project under the guidance of the provisions of ANSI/ASME NQA-1 program requirements for Nuclear Facilities (page 3-99).

Several wells were installed to obtain background data for the EAV and to monitor the facility for startup. Several wells monitored at the EAV and up gradient to the EAV contained contaminants above the drinking water standards. This contamination was due to tritium, radium, tetrachloroethylene, and trichloroethylene (page 2-38).

No specific mention of the distribution of the waste in the disposal units was found. However, the discussions lead me to believe that the waste was considered to be a uniform composition. 
Table D-4. (continued).

Parameter

5.2.2 What assumptions are made about the distribution of waste in disposal units for. calculating dose to a hypothetical inadvertent intruder?
ORNL (SWSA 6)

SRS (E-Area Vaults)

For the agriculture scenario, an intruder is assumed to construct a house directly on top of a disposal unit with the foundation extending into the waste itself. Waste is assumed to be exhumed during the construction of the foundation and the waste is assumed to be indistinguishable from native soil. Some of the exhumed waste is assumed to be mixed with native soil in the intruder's vegetable garden and the following exposure pathways are assumed to occur: 1. ingestion of vegetables grown in the contaminated soil;

2. direct ingestion of contaminated soil from the garden in conjunction with vegetable intakes; 3. external exposure to contaminated soil while working in the garden or residing in the home on top of the disposal facility; and

4. inhalation of radionuclides suspended into air from contaminated soil while working in the garden or while residing in the home (page 3-21).
No specific mention of the distribution of the waste in the disposal units was found. However, the discussions lead me to believe that the waste was considered to be a uniform composition. 
Table D-5. Non-DOE Performance Assessment Practices, Texas, California, and Nebraska.

\begin{tabular}{|c|c|c|c|}
\hline Parameter & Texas & California & Nebraska \\
\hline $\begin{array}{l}\text { 1. General } \\
1.1 \text { Format \& content } \\
\text { 1.1.1 What is the } \\
\text { general format? What } \\
\text { are the contents for the } \\
P A ?\end{array}$ & $\begin{array}{l}\text { As an agreement state, the Texas } \\
\text { regulations closely parallel the } \\
\text { NRC's } 10 \text { CFR } 61 \text {. Because the } \\
\text { Texas regulatory agency has not } \\
\text { issued separate guidance, the } \\
\text { developing agency has based the } \\
\text { format and content of the } \\
\text { performance assessment on the } \\
\text { NRC guidance. }\end{array}$ & $\begin{array}{l}\text { California's disposal regulations } \\
\text { incorporate } 10 \text { CFR } 61 \text { by } \\
\text { reference. Therefore, the state } \\
\text { regulations are virtually identical } \\
\text { to the federal. Because the state } \\
\text { did not issie separate guidance, } \\
\text { the developing organization based } \\
\text { the format and content of the } \\
\text { performance assessment on NRC }\end{array}$ & $\begin{array}{l}\text { The License Program Plan Manual } \\
\text { issued by the Dept. of Environmental } \\
\text { Quality and the Dept. of Health } \\
\text { prescribes that applicants follow the } \\
\text { format and contents in NUREG-1199, } \\
\text { and NUREG-1200. The Manual also } \\
\text { cites other NUREG documents as state } \\
\text { guidance. }\end{array}$ \\
\hline
\end{tabular}

1.2 Approval process

1.2.1 What is the formal process for final approval?
The initial performance assessment is approved as part of the licensing process.
1.3 Review process

1.3.1 What formal process does the PA go through before submittal for approval?

\subsection{PA maintenance}

1.4.1 Is $P A$ reviewed and updated as parameters change?

\subsection{Method for}

Evaluating Uncertainty 1.5.1 Deterministic-tic or probabilistic? What kind of uncertainty or sensitivity analysis, if any?

\subsection{Computer Codes \\ 1.6.1 Is there an approval process for $P A$ codes that is separate from the $P A$ approval process, itself?}

1.6.2 Does the code approvall review process include Validation? Verification?
The PA itself was peer reviewed by the applicant, the Texas LLRW Disposal Authority, and its contractors prior to formal review as part of the license application.

The PA will be revised and updated once source term data reflecting actual waste disposed, and field data become available.

The PA takes a deterministic approach using conservative assumptions, with sensitivity analyses of critical parameters.

No

No

The PA will be revised and updated once source term data reflecting actual waste disposed, and field data become available

The PA takes a deterministic approach using conservative assumptions, with sensitivity analyses of critical parameters.

The QA program required by the state requires verification of any codes used in PA.
The PA will be revised and updated once source term data reflecting actual waste disposed, and field data become available.

The PA takes a deterministic approach using conservative assumptions, with sensitivity analyses of critical narameters. 
Table D-5. (continued).

\begin{tabular}{|c|c|c|c|}
\hline Parameter & Texas & California & Nebraska \\
\hline $\begin{array}{l}\text { 2. Receptor (most } \\
\text { exposed individual) } \\
2.1 \text { Receptor scenario } \\
\text { 2.1.1 What are the } \\
\text { general (non-site- } \\
\text { specific assumptions?) }\end{array}$ & $\begin{array}{l}\text { The scenarios are consistent with } \\
\text { those described in NRC guidance. } \\
\text { In general, the maximally } \\
\text { exposed individual lives and } \\
\text { works as close to the site as } \\
\text { possible and derives all } \\
\text { sustenance from sources adjacent } \\
\text { to the site. }\end{array}$ & $\begin{array}{l}\text { Twenty-five separate scenarios } \\
\text { are used to model dose to the } \\
\text { maximally exposed individual. } \\
\text { The assumptions vary by } \\
\text { scenario. In general, maximally } \\
\text { exposed receptors live and work } \\
\text { as close to the site as possible and } \\
\text { derive all sustenance from sources } \\
\text { adjacent to the site. }\end{array}$ & $\begin{array}{l}\text { The scenarios are consistent with those } \\
\text { described in the NRC's draft BTP on } \\
\text { PA. An individual drills a well at the } \\
\text { site boundary, drinks water from the } \\
\text { well, eats produce irrigated from the } \\
\text { well, and consumes livestock watered } \\
\text { from the well. Inhalation is considered } \\
\text { along with ingestion. }\end{array}$ \\
\hline
\end{tabular}

\subsubsection{What site- specific assumptions are used?}

\subsubsection{Are variations used to model against possible future environmental conditions?}

\section{2,2 Dose standard}

2.2.1 What dose value to the individual is the standard?

\subsection{Point of compliance 2.3.1 Where is the most exposed individual located with respect to the disposal site?}

\subsection{Time of} compliance

2.4.1 What is the time of compliance? (Time certain or peak dose?)
Although field data did not suggest a groundwater pathway, an assumption was made that eventually a portion of the source term would make its way to the groundwater. Most of the waste was assumed to migrate upward based on water potential gradients measured at the site. Food uptake pathways were examined although the site location makes it doubtful that farming could take place.

Global climatic change was not assumed. Variations in rainfall which directly impacted infiltration rates (the key parameter limiting transport at the site) was evaluated.

Assessment was conducted using ICRP 26/30 methodology so that doses are effective dose equivalents (EDE) not directly comparable to the regulatory limit. Based on discussions with the NRC, it may require all state regulations to be amended to conform with the 15 mrem EDE proposed by EPA.

At the boundary of the licensed disposal site (as opposed to the larger property boundary).

For each radionuclide the time to peak dose was reported since the codes allow for such an analysis.
No special credit is taken for the remoteness of the disposal site location.

Global climate change was not assumed. However, climatological events far in excess of expected values were used as assumptions in evaluating compliance with performance objectives.

The current regulatory standard of $25 / 75 / 25 \mathrm{mrem} / \mathrm{yr}$ to the most exposed individual was used. (See federal regulatory requirements.)

In addition dose standards of 100 mrem/yr offsite gamma (10 CFR 20); $4 \mathrm{mrem} / \mathrm{yr}$ for primary drinking water (40 CFR); and 10 $\mathrm{mrem} / \mathrm{yr}$ for NESHAPS (40 CFR) were used.

The point of compliance differed for different scenarios, including at the fence line, directly over waste trenches, or at the nearest residence.

Measurements were made to either peak dose or to a timécertain depending on the specific radionuclide. Dose contribution for extremely long-lived radionuclides were made to specific times.
An offsite wetland is included in the performance assessment. (See time of compliance, below.)
Consistent with federal guidance, global climatic change was not assumed.

The current regulatory standard of 25/75/25 mrem/yr to the most exposed individual was used. (See federal regulatory requirements.)

Particle tracking was used to determine the point of maximum exposure on the site boundary for the water well scenario. '

Exposure was variously calculated to: the time of peak concentration at the site boundary well, at the time of peak concentration at the wetland, at the end of transport simulations $(10,000$ years $)$ and the worst case. 
Table D-5. (continued).

\begin{tabular}{|c|c|}
\hline Parameter & Texas \\
\hline $\begin{array}{l}2.4 .2 \text { What } \\
\text { assumptions are made } \\
\text { about future land } \\
\text { ownership } \\
\text { /control? }\end{array}$ & $\begin{array}{l}\text { Same as federal regulatory } \\
\text { guidance. }\end{array}$ \\
\hline $\begin{array}{l}\text { 2.4.3 What } \\
\text { institutional control } \\
\text { period is used? }\end{array}$ & $\begin{array}{l}\text { Same as federal regulatory } \\
\text { guidance. }\end{array}$ \\
\hline $\begin{array}{l}2.4 .4 \text { What } \\
\text { assumptions are made } \\
\text { about active and } \\
\text { passive controls that } \\
\text { may affect modeling? }\end{array}$ & $\begin{array}{l}\text { Same as federal regulatory } \\
\text { guidance. }\end{array}$ \\
\hline $\begin{array}{l}2.5 \text { Dose conversion } \\
2.5 .1 \text { What is the } \\
\text { source of dose } \\
\text { conversion factors? } \\
\text { What assumptions are } \\
\text { used? }\end{array}$ & $\begin{array}{l}\text { EPA Federal Guidance Report } \\
\text { Nos. } 11 \text { and } 12 \text { are the primary } \\
\text { sources. Ingrowth was } \\
\text { considered by assuming that the } \\
\text { short lived daughters of } \mathrm{Pb}-210 \text {, } \\
\mathrm{Pa}-226, \text { Th-228, Th-232, U-235 } \\
\text { and } \mathrm{U}-238 \text { are in equilibrium with } \\
\text { the parent and the dose } \\
\text { conversion factors are summed } \\
\text { unless the source indicated that } \\
\text { this had already been done. } \\
\text { Pu-241 and Am-241 were } \\
\text { transformed to equivalent } \\
\text { concentrations of Np-237 and } \\
\text { analyzed as if they were } \\
\text { neptunium. }\end{array}$ \\
\hline
\end{tabular}

3. Receptor

3.1 Receptor scenario

3.1.1 What are the general (non-sitespecific assumptions?

\subsubsection{What site-} specific assumptions are used?

\subsubsection{Are variations used to model against possible future environmental conditions?}

\subsection{Dose standard} 3.2.1 What dose value to the individual is the standard?
Although not specifically required by state or federal regulations, selected scenarios in NUREG1199 applicable to the site location were used to calculate the dose to an inadvertent intruder.

A scenario was run wherein an intruder drilled a well over a Class $\mathbf{C}$ waste canister filled with ion exchange resins.

No

Same as standard used by the NRC, 500 mrem per year.
Same as federal regulatory guidance.

Same as federal regulatory guidance.

Same as federal regulatory guidance.

The library of dose conversion factors is derived from RADRISK, a modified INREM-II Code (ORNL/NUREG/TM-84, June 1978)

Selected scenarios were run to calculate potential dose to an inadvertent intruder. The bounding case was the "basement gas scenario."

The basement gas scenario assumes a house is built over B/C-30 trench after the end of the institutional control period.

Not applicable (see above)

Not applicable (see above)

Not applicable (see àbove)
See federal regulatory requirements. Because the waste classification and disposal system include technical requirements to prevent the inadvertent intruder from contacting the waste, no dose is assumed.

Not applicable (see above) 
Table D-5. (continued).

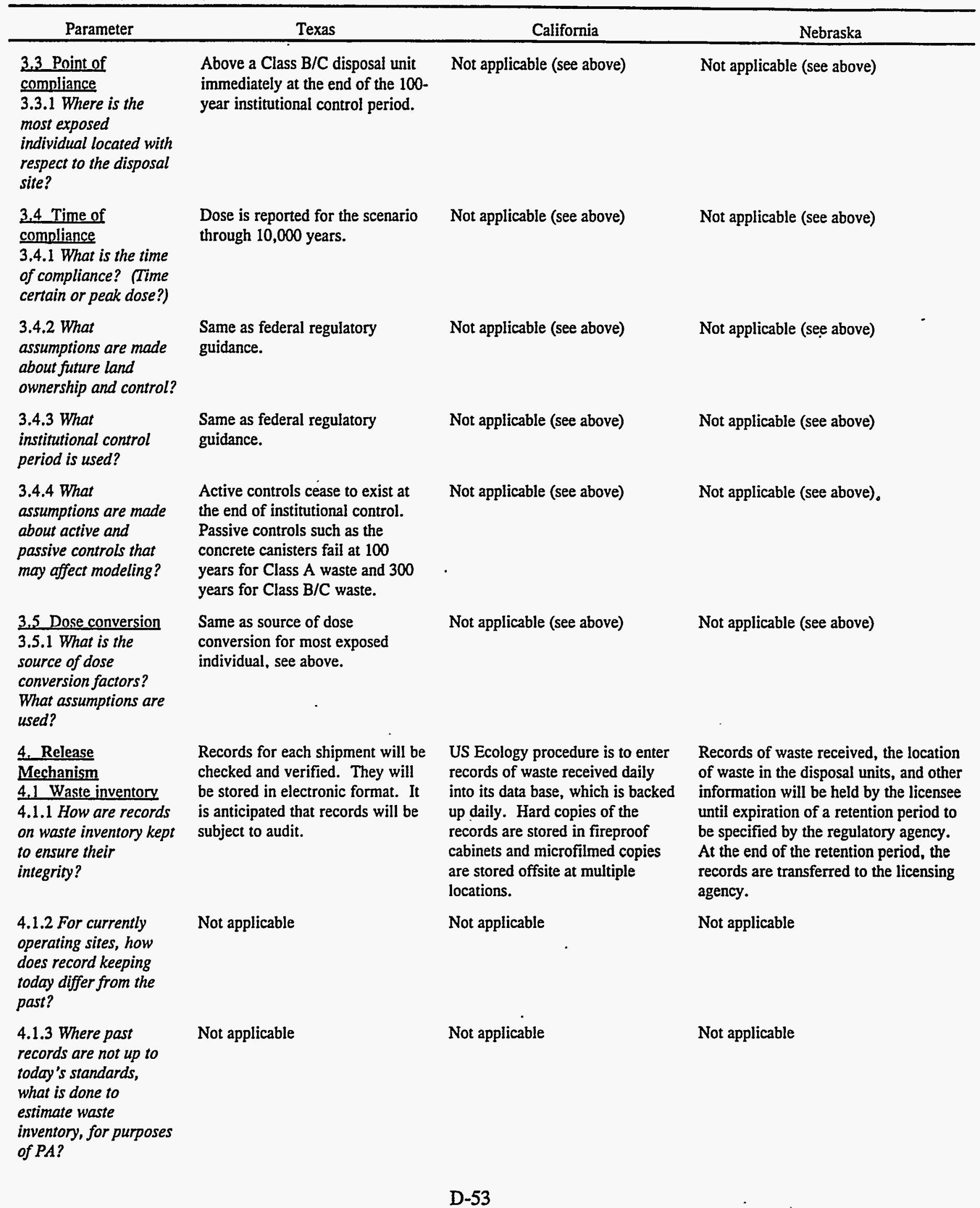


Table D-5. (continued).

\begin{tabular}{|c|c|c|c|}
\hline Parameter & Texas & California & Nebraska \\
\hline $\begin{array}{l}4.2 \text { Source term } \\
4.2 .1 \text { What } \\
\text { assumptions are made } \\
\text { about the release of } \\
\text { radionuclides from the } \\
\text { various waste forms? }\end{array}$ & $\begin{array}{l}\text { After it is assumed that the } \\
\text { concrete canisters and the waste } \\
\text { form fail, some water will } \\
\text { percolate through the disposal } \\
\text { unit cover system and contact the } \\
\text { waste. Neither surface washoff } \\
\text { or dissolution are expected to be } \\
\text { significant. Leaching will be } \\
\text { dominated by diffusion. Except } \\
\text { for the release of radioactive } \\
\text { gases, nuclides are assumed to } \\
\text { leave the disposal unit only with } \\
\text { percolating water (advection). } \\
\text { The maximum leach rate occurs } \\
\text { at the time of failure of the waste } \\
\text { form or canister. This leach rate } \\
\text { is used throughout the PA } \\
\text { calculations. }\end{array}$ & $\begin{array}{l}\text { No credit was taken for waste } \\
\text { packaging (except for high } \\
\text { integrity containers containing } \\
\text { certain Class B and C wastes). } \\
\text { The bounding case scenario } \\
\text { assumed that all waste was } \\
\text { available for transport. }\end{array}$ & \\
\hline $\begin{array}{l}\text { 4.2.2 For purposes of } \\
\text { PA during operations } \\
\text { or for closure, is all } \\
\text { waste included in the } \\
\text { source term? }\end{array}$ & Yes & Yes & Yes \\
\hline $\begin{array}{l}\text { 4.2.3 What is the } \\
\text { source of scaling } \\
\text { factors for indirectly } \\
\text { measured radio- } \\
\text { nuclides? }\end{array}$ & $\begin{array}{l}\text { Shipping manifests for actual } \\
\text { waste shipped for disposal in the } \\
\text { past from the region are used for } \\
\text { the source term. These do not } \\
\text { indicate the source of scaling } \\
\text { factors for indirectly measured } \\
\text { radionuclides. Disposal permit } \\
\text { requirements in states where } \\
\text { waste has been disposed have } \\
\text { required waste generators } \\
\text { preparing these manifests to use } \\
\text { scaling methods that have been } \\
\text { approved by regulatory agencies. }\end{array}$ & $\begin{array}{l}\text { Shipping manifests for actual } \\
\text { waste shipped for disposal in the } \\
\text { past from the region are used for } \\
\text { the source term. These do not } \\
\text { indicate the source of scaling } \\
\text { factors for indirectly measured } \\
\text { radionuclides. Disposal permit } \\
\text { requirements in states where } \\
\text { waste has been disposed have } \\
\text { required waste generators } \\
\text { preparing these manifests to use } \\
\text { scaling methods that have been } \\
\text { approved by regulatory agencies. }\end{array}$ & $\begin{array}{l}\text { The source inventory (except Tc-99) } \\
\text { was based on records for waste shipped } \\
\text { for disposal from the Central Compact } \\
\text { region from generators that produced } \\
\text { more than } 10 \text { cubic feet per year. The } \\
\text { source term for I- } 129 \text { and TC- } 99 \text { were } \\
\text { modeled using the } 3 R-S t a t \text { code, which } \\
\text { was recently approved by the NRC. } \\
\text { Only radionuclides with half-lives } \\
\text { greater than } 10 \text { years are considered in } \\
\text { the groundwater transfer mechanism. } \\
\text { Groundwater modeling begins at the } \\
\text { end of the } 30 \text {-year operational life. }\end{array}$ \\
\hline
\end{tabular}

\section{Pathways}

5.1 Site characteristics

5.1.1 Must data about site characteristics

meet any quality

requirements or standards in order to

be used in PA?

\subsubsection{What is done to} avoid the potential for "masking" from nearby nuclear facilities?
Same as federal regulatory guidance. The Texas LLRWD Authority uses NUREG-1293 as the basis of its QA program.

There are no nearby nuclear facilities.
Same as federal regulatory guidance.

There are no nearby nuclear facilities.
Same as federal regulatory guidance.

There are no nearby nuclear facilities. 
Table D-5. (continued).

\begin{tabular}{|c|c|c|c|}
\hline Parameter & Texas & California & Nebraska \\
\hline $\begin{array}{l}5.2 \text { Waste distribution } \\
5.2 .1 \text { What } \\
\text { assumptions are made } \\
\text { about the distribution } \\
\text { of waste in disposal } \\
\text { units for calculating } \\
\text { dose to Most Exposed } \\
\text { Individual? }\end{array}$ & $\begin{array}{l}\text { Waste is assumed to be uniformly } \\
\text { distributed throughout the } \\
\text { disposal units. }\end{array}$ & $\begin{array}{l}\text { Waste is assumed to be uniformly } \\
\text { distributed within the respective } \\
\text { disposal units. The source term } \\
\text { in } \mathrm{BC} / 30 \text { trench was limiting. A } \\
\text { separate tritium analysis assumed } \\
\text { a } 100^{\prime} \text { by } 100^{\prime} \text { footprint for } \\
\text { preferential migration. }\end{array}$ & $\begin{array}{l}\text { The entire class } A \text { inventory is } \\
\text { assumed to be in one Class } A \text { cell. } \\
\text { The entire Class } B / C \text { waste inventory } \\
\text { is assumed to be in one } B / C \text { cell. }\end{array}$ \\
\hline $\begin{array}{l}5.2 .2 \text { What } \\
\text { assumptions are made } \\
\text { about the distribution } \\
\text { of waste in disposal } \\
\text { units for calculating } \\
\text { dose to Inadvertent } \\
\text { Intruder? }\end{array}$ & $\begin{array}{l}\text { The inadvertent intruder is } \\
\text { assumed to drill a well that } \\
\text { penetrates a } 200 \text { cubic foot liner } \\
\text { containing ion exchange resins } \\
\text { that at the time of disposal contain } \\
\text { Cs-137 at the Class C } \\
\text { concentration limit. }\end{array}$ & $\begin{array}{l}\text { Not applicable. See Receptor } \\
\text { Scenario for inadvertent intruder, } \\
\text { above. }\end{array}$ & $\begin{array}{l}\text { Drums of spent resin are used in the } \\
\text { inadvertent intruder scenario, to } \\
\text { provide a worst case scenario. [Was } \\
\text { modeling done on an inadvertent } \\
\text { intruder scenario? See above] }\end{array}$ \\
\hline
\end{tabular}


Table D-6. Non-DOE Performance Assessment Practices, North Carolina, Washington, and South Carolina.

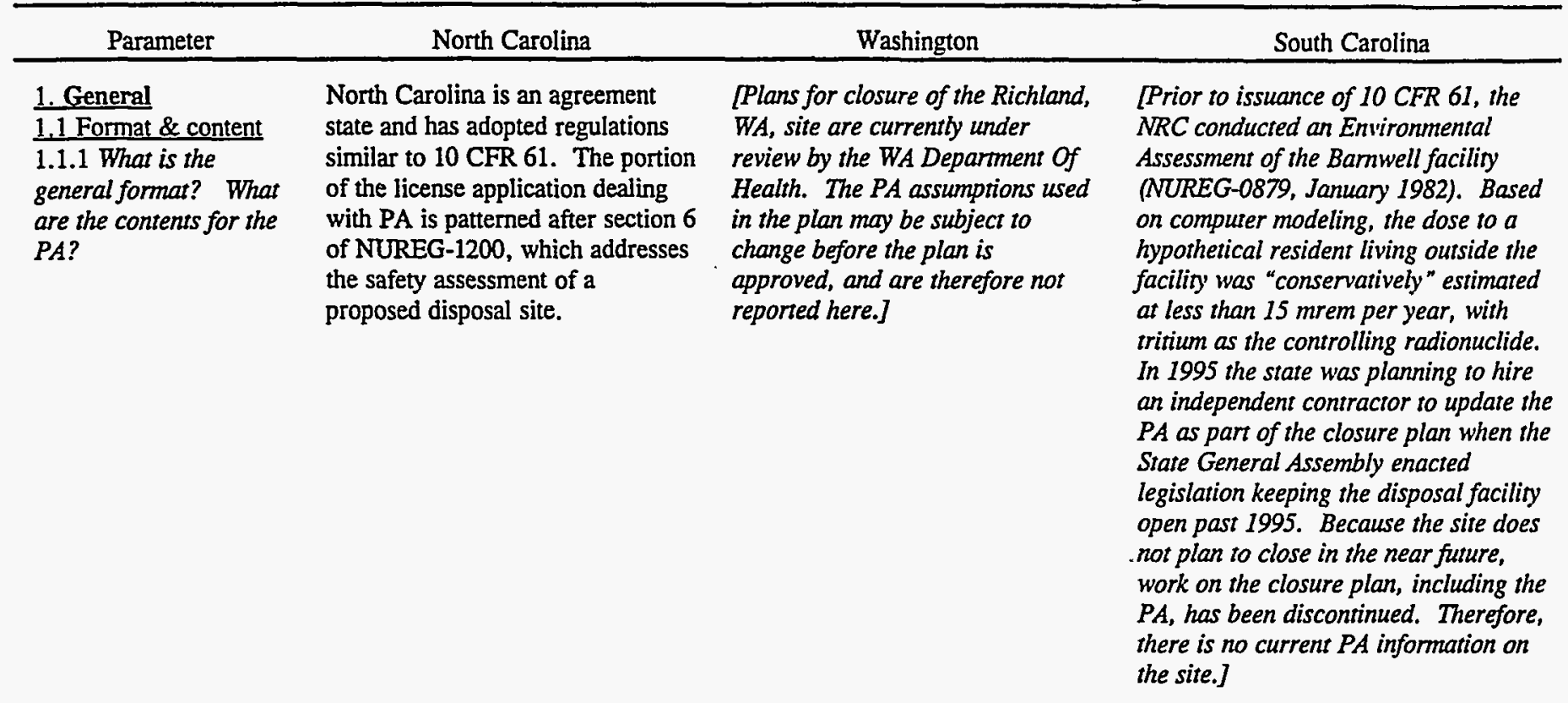

1.2 Approval process

1.2.1 What is the formal process for final approval?

\subsection{Review process}

1.3.1 What formal process does the PA go through before submittal for approval?

\subsection{PA maintenance} 1.4.1 Is PA reviewed and updated as parameters change?

\subsection{Method for} Evaluating Uncertainty 1.5.1 Deterministic or probabilistic? What kind of uncertainty or sensitivity analysis, if any?

\subsection{Computer Codes}

1.6.1 Is there an approval process for $P A$ codes that is separate from the $P A$ approval process, itself?
The initial performance assessment is approved as part of the overall process for approving the license application and issuing an operating license.

A management review group within Chem-Nuclear, the license applicant, conducted a formal peer review. The NC LLRW Authority did not formally review and approve the PA.

The PA will be revised and updated once source term data reflecting actual waste disposed, and field data become available.

Based on a report from an independent consultant, the NC LLRW Authority has directed Chem-Nuclear to make revisions to the license application that would better account for uncertainty and propagation of error. The revised approach would make more use of sitespecific data on fractures, dikes and faults.

No
[Plans for closure of the Richland, WA, site are currently under review by the WA Department Of Health. The PA assumptions used in the plan may be subject to change before the plan is aproved, and are therefore not reported here.] 
Table D-6. (continued).

\begin{tabular}{|c|c|c|c|}
\hline Parameter & North Carolina & Washington & South Carolina \\
\hline $\begin{array}{l}1.6 .2 \text { Does the code } \\
\text { approvall } \\
\text { review process include } \\
\text { Validation? } \\
\text { Verification? }\end{array}$ & $\begin{array}{l}\text { The applicant plans to use only } \\
\text { codes that have already been } \\
\text { validated and verified. }\end{array}$ & & \\
\hline $\begin{array}{l}\text { 2. Receptor (most } \\
\text { exposed indjividual) } \\
2.1 \text { Receptor scenario } \\
2.1 .1 \text { What are the } \\
\text { general (non-site- } \\
\text { specific assumptions?) }\end{array}$ & $\begin{array}{l}\text { The scenario is consistent with that } \\
\text { described in the NRC's draft BTP } \\
\text { on PA. The scenario involves a . } \\
\text { person who sustains himself at the } \\
\text { site by drinking water, eating } \\
\text { crops and feeding livestock from a } \\
\text { well at the site border. }\end{array}$ & & . \\
\hline $\begin{array}{l}2.1 .2 \text { What site-specific } \\
\text { assumptions are used? }\end{array}$ & $\begin{array}{l}\text { At this site, a scenario built around } \\
\text { an adjacent resident is not credible } \\
\text { because of the lack of } \\
\text { groundwater. At the wettest spot, } \\
\text { which is considerable distance off } \\
\text { site, only } 8 \text { gallons per minute are } \\
\text { obtained. }\end{array}$ & & \\
\hline $\begin{array}{l}2.1 .3 \text { Are variations } \\
\text { used to model against } \\
\text { possible future } \\
\text { environmental } \\
\text { conditions? }\end{array}$ & $\begin{array}{l}\text { Consistent with federal guidance, } \\
\text { global climatic change was not } \\
\text { assumed. }\end{array}$ & & \\
\hline $\begin{array}{l}2.2 \text { Dose standard } \\
2.2 .1 \text { What dose value } \\
\text { to the individual is the } \\
\text { standard? }\end{array}$ & $\begin{array}{l}\text { The license application is being } \\
\text { revised to report against a } 15 \\
\text { mrem Committed Effective Dose } \\
\text { (CED), in anticipation of } \\
\text { regulatory changes. }\end{array}$ & . & \\
\hline $\begin{array}{l}2.3 \text { Point of } \\
\text { compliance } \\
2.3 .1 \text { Where is the most } \\
\text { exposed individual } \\
\text { located with respect to } \\
\text { the disposal site? }\end{array}$ & $\begin{array}{l}\text { The individual is located at the } \\
\text { edge of the buffer zone, which is } \\
1000 \text { feet from the edge of the } \\
\text { disposal units. This point of } \\
\text { compliance is currently under } \\
\text { review and may be changed. }\end{array}$ & & \\
\hline $\begin{array}{l}2.4 \text { Time of } \\
\text { compliance } \\
2,4.1 \text { What is the time } \\
\text { of compliance? (Time } \\
\text { certain or peak dose?) }\end{array}$ & $\begin{array}{l}\text { For each radionuclide the time to } \\
\text { peak dose was reported since the } \\
\text { codes allow for such an analysis. }\end{array}$ & & v \\
\hline $\begin{array}{l}2.4 .2 \text { What assumptions } \\
\text { are made about future } \\
\text { land ownership/ } \\
\text { control? }\end{array}$ & $\begin{array}{l}\text { The state owns or will own land } \\
\text { surrounding the site, but is not } \\
\text { taking credit for the additional land } \\
\text { in setting the point of compliance. }\end{array}$ & & \\
\hline
\end{tabular}


Table D-6. (continued).

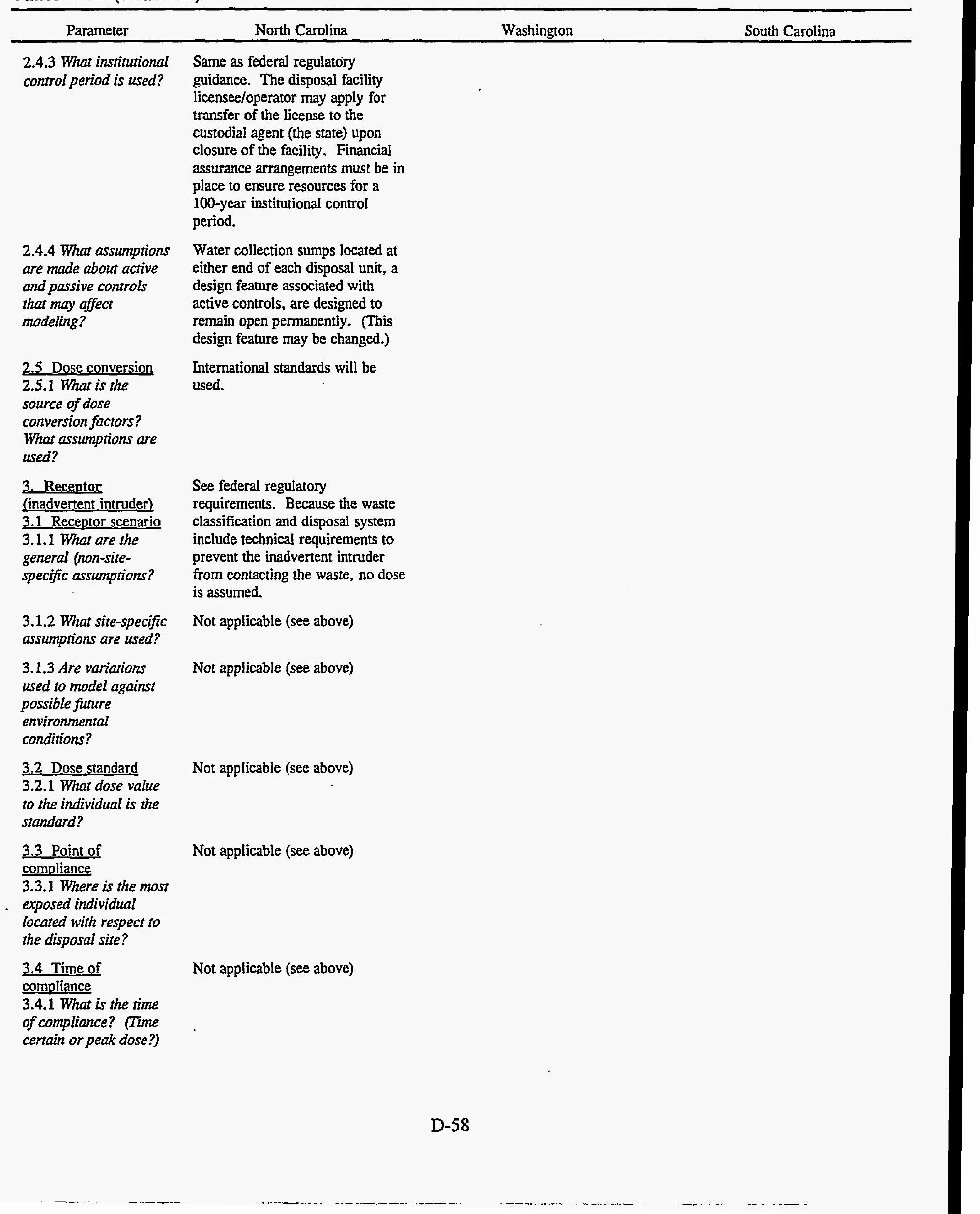


Table D-6. (continued).

\begin{tabular}{l} 
Parameter \\
\hline 3.4.2 What assumptions \\
are made about future \\
land ownership and \\
control? \\
3.4.3 What institutional \\
control period is used? \\
3.4.4 What assumptions \\
are made about active \\
and passive controls \\
that may affect \\
modeling?
\end{tabular}

3.5 Dose conversion 3.5.1 What is the source of dose conversion factors? What assumptions are used?

4. Release Mechanism 4.1 Waste inventory 4.1.1 How are records on waste inventory kept to ensure their integrity?

4.1.2 For currently operating sites, how does record keeping today differ from the past?

\subsubsection{Where past} records are not up to today's standards, what is done to estimate waste inventory, for purposes of $P A$ ?

\subsection{Source term} 4.2.1 What assumptions are made about the release of radionuclides from the various waste forms?

North Carolina

Washington

South Carolina

Not applicable (see above)

Not applicable (see above)

Not applicable (see above)

Not applicable (see above)

North Carolina regulations prescribe detailed requirements. These include transfer of quarterly reports including the location and inventory of disposed waste. A copy of the report is filed with the State Records Center for permanent retention.

Not applicable

Not applicable

In the license application, the anticipated waste forms were grouped into categories based upon partitioning characteristics. (This approach is currently being reviewed.)

4.2.2 For purposes of $P A$ during operations or for closure, is all waste included in the source term? 
Table D-6. (continued).

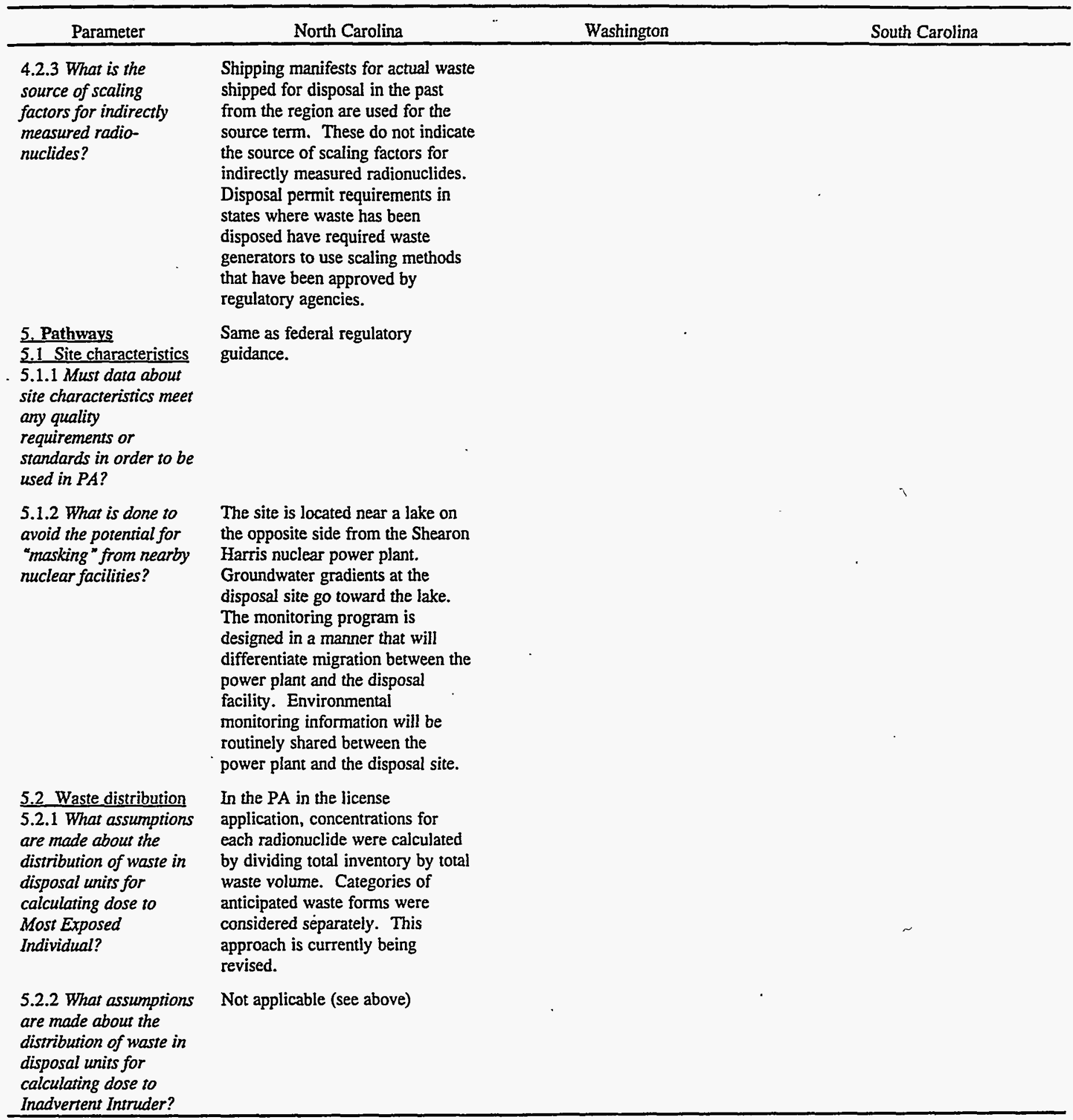




\section{REFERENCES}

1. M.J. Case, M.D. Otis, Guidelines for Radiological Performance Assessment of DOE Low-Level Radioactive Waste Disposal Sites, DOE/LLW-62T, July 1988.

2. M.J. Case, et al., Recommended Format and Content for DOE Low-Level Waste Disposal Facility Radiological Performance Assessment Reports, DOE/LLW-81, April 1989.

3. R.L. Dodge, et al., Performance Assessment Review Guide for DOE Low-Level Radioactive Waste Disposal Facilities, DOE/LLW-93, October 1991.

4. D.E. Wood, et al., Performance Assessment Task Team Progress Report, DOE/LLW-157, May 1994.

5. National Low Level Waste Management Program, Environmental Monitoring for Low Level Waste Disposal Sites, Low Level Waste Management Handbook Series, DOE/LLW-13Tg, Revision 2, Volume 1, February 1990

6. U.S. Department of Energy, External Dose-Rate Conversion Factors for Calculation of Dose to the Public, DOE/EH-0070, July 1988

7. U.S. Department of Energy, Internal Dose Conversion Factors for Calculation of Dose to the Public, DOE/EH-0071, July 1988

8. Eckerman, K.F., A.B. Wolbarst, A.C.B. Richardson, Limiting Values of Radionuclide Intake and Air Concentration and Dose Conversion Factors for Inhalation Submersion and Injection, EPA-520, RFG-11, 1988

9. Methodology for Compliance with DOE Order 5820.2A Chapter III: Management of Low-Level Radioactive Waste, Prepared by EG\&G Idaho, Inc., DOE/LLW-75T, February 1989

10. A Comprehensive Inventory of Radiological and Nonradiological Contaminants in Waste Buried in the Subsurface Disposal Area of the INEL RWMC During the Years 1952-1983, Prepared by EG\&G Idaho, Inc., EGG-WM-10903, April 1994

11. INEL Reusable Property, Recyclable Materials, and Waste Acceptance Criteria (RRWAC), DOE/ID10381, Revision 3, February 21, 1995

12. S. J. Maheras, et al., Radioactive Waste Management Complex Low-Level Waste Radiological Performance Assessment, EGG-WM-8773, May 1994

13. L.E. Plansky, S.A. Hoiland, Analysis of the Low-Level Waste Radionuclide Inventory for the Radioactive Waste Management Complex Performance Assessment, EGG-WM-9857, Revision 1, June 1992

14. M.I. Wood, et al., Performance Assessment for the Disposal of Low-Level Waste in the 200 West Area Burial Grounds, WHC-EP-0645, November 1994

15. M.W. Kozak, et al., Background information for the Development of a Low-Level Waste Performance Assessment Methodology, NUREG/CR-5453, SAND90-0375, Vol. 5, 1990 
16. Performance Assessment for Continuing and Future Operations at Solid Waste Storage Area 6, Prepared by ORNL, ORNL-6783, February 1994

17. R.L. Inman, J.C. Helton, A Comparison of Uncertainty and Sensitivity Analysis Techniques for Computer Models, NUREG/CR-3904, SAND84-1461, Sandia National Laboratory, Albuquerque, NM, 1985

18. R.H. Gardner, et al., PRISM, A Systematic Method for Determining the Effect of Parameter Uncertainties on Model Predictions, Report NW-83-555, Studsvik Energiteknik AB, Nykoping, Sweden, 1983

19. Radiological Performance Assessment for the E-Area Vaults Disposal Facility, Prepared by Westinghouse Savannah River Company, WSRC-RP-94-218, April 15, 1994

20. K.F. Eckerman, J.C. Ryman, External Exposure to Radionuclides in Air, Water, and Soil, Federal Guidance Report No. 12, EPA 402-R-93-081, Oak Ridge National Laboratory and U.S. Environmental Protection Agency, 1993

21. D.C. Kocher, A.L. Sjoreen, Dose-Rate Conversion Factors for External Exposure to Photon Emitters in Soil, Health Physics, 48:193, 1985

22. Memorandum from T. P. Grumbly and T. J. O'Toole, Interim Policy on Regulatory Structure for Low Level Management and Oversight," July 21, 1995. 